FRENCH RENAISSANCE COMEDY, 1552-1630

\author{
Brian Jeffery
}

A Thesis Submitted for the Degree of PhD

at the

University of St Andrews

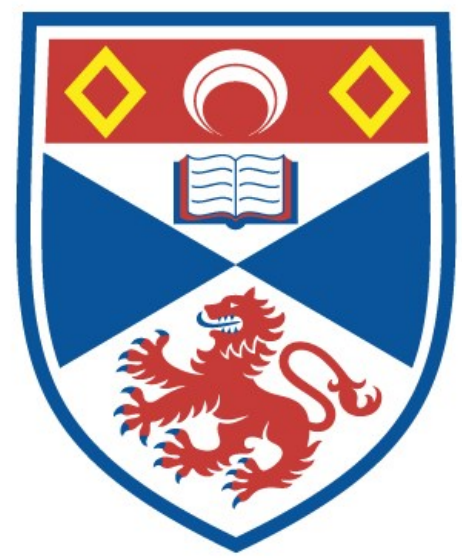

1967

Full metadata for this item is available in

St Andrews Research Repository

at:

http://research-repository.st-andrews.ac.uk/

Please use this identifier to cite or link to this item:

http://hdl.handle.net/10023/13374

This item is protected by original copyright 
In accordance with Ordinances and Regulations F IV 111 (amo),

a) I declare that this thesis has been composed by me; that the work of which it is a reoord has been done by mes and that it has not been accepted in any previous application for a hizher degree.

b) The date of my admission as a research stucient under Ordinanoe General No. 12, and as a candidate for the descee of Ph.D. under Ordinance 3t. Andrewe NO. 88, was Octoper 1964.

c) I certify that the conditions of the Ordinances and Regulations have been fulfilled,

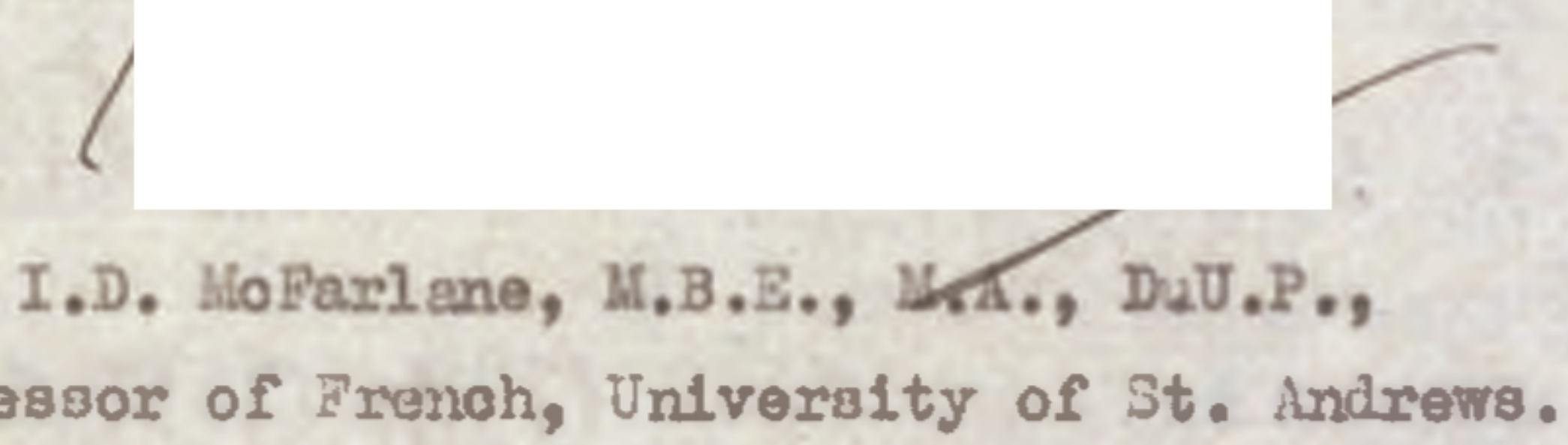

Professor of French, University of St. Andrews. 
ProQuest Number: 10170746

All rights reserved

INFORMATION TO ALL USERS

The quality of this reproduction is dependent upon the quality of the copy submitted.

In the unlikely event that the author did not send a complete manuscript and there are missing pages, these will be noted. Also, if material had to be removed, a note will indicate the deletion.

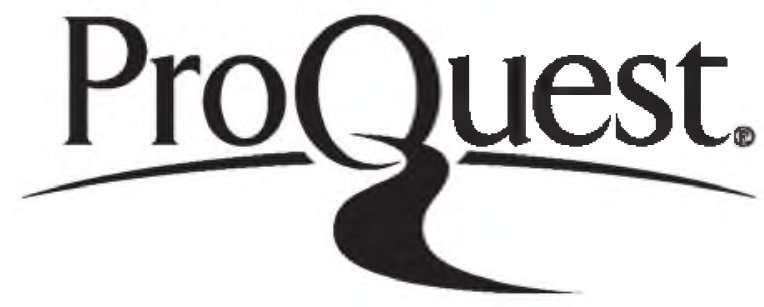

ProQuest 10170746

Published by ProQuest LLC (2017). Copyright of the Dissertation is held by the Author.

All rights reserved.

This work is protected against unauthorized copying under Title 17, United States Code Microform Edition (C) ProQuest LLC.

ProQuest LLC.

789 East Eisenhower Parkway

P.O. Box 1346

Ann Arbor, Ml $48106-1346$ 


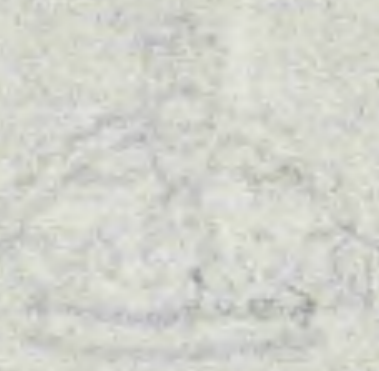

BTENCE RGNAISSABOS COKELY

$$
\begin{gathered}
1552-1630 \\
\text { by } \\
\text { Brian Jaffery }
\end{gathered}
$$

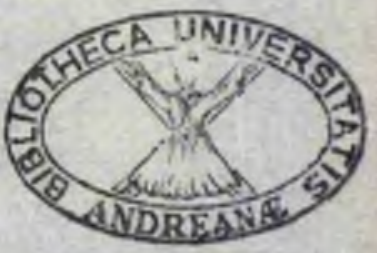




$$
\ln 5560
$$


4. thesis presented for the degree of Doctor of Philosophy in the Unitersity of St. indrews, June 1967. 
CORTERT:3

List of 11lustrations

Prefece

Introduction

I. The pleys

1. Plélade comedr: $1552-1574$

16

2. Itallanate oomedys 1575-1588

3. To Corne111日's Mêliter 1589-1630

35

62

II. The tage

1. The 11luotrated editions of Teronoe

2. Farces

3. Itallan comady

4. Lediuval sets, Serlio and the Monolre de Haholot

I

1

5. Performanoes

6. The evilenee of the plays: $1550-1570$

80

85

90

7. $n$

11. $\quad 2571-1630$

95

102

110

8. Aotion on stages styles of soting; costumes, propertles; masks; etago-d1reotions

126

134

III. The conventions

1. Comic theory in the Brench Renalssance

142

2. Plot

3. Character.

4. Speeah

Conoluaion

Appendix As symopses of the plays .

Appendlx 3s Grórin's In aubertine

31 bllography.

Illugtratlons. 


\section{List of 1llustrations}

1. A page of a copy of Jacques Grévin's Theatre, Paris, 1561, in the Iusee Plantin-Moretus, Anvers, showing changes in Grérin's hand to La tresorière, I, 1, probably for a projected new edition. Cf. pp. 22-3.

L. Pinvert, Jacques Grévin, Paxis, 1899, p. 65.

2. Frunçois d'Amboise, Les liesoolitaines, Paris, 1584, titlepage (Bibliothèque de l'Arsenal). Cf. bibliography and pp. 46-7.

3. Woodcut in Trechsel's edition of Terence, Lyon, 1493, showing the whole theatre. Cf. pp. $60 \mathrm{ff}$.

T.E. Lawrenson and Helen Purkis, "Les éditions 1llustrées de Térence dans I'histoire du théâtre", Le lieu thêtrel à la Renaissanoe, ed. Jean Jaoquot, Paris, 1964, fig. 12.

4. Another, showing compartments in a line. Ibid., fiz. 10 .

5. Another, showing "baldaquin" arrangement of compartments. Ibid., fig. 5 .

6. Open-air farce stagr, 16th c. Cambrai, Bibliothèque Municipale, Mis 126, vol. II, f. 53. Cf. pp. 86-?.

I. Houssinao, Le thếtre, Paris, 1957, p. 123.

7. Open-air farce stage: detail of a painting by P. Balten, Rijksmiseum, Amsterdam. Cf. pp. 86-7.

Ibld., p. 197.

8. A farce stage, showing sellers of the medicine "L'Orvietan". Print in the Bibliothèque Nationale, Cabinet des Sstampes, $\mathrm{Tb}+1$, rol. 1, B. 344. Cf. pp. 86-7.

Allardyce N1co11, Masks, Nimes and Mirroles [1931], New York, 1963, fig. 150. 
9. Illustration from Compositloss de inhtorique, Lyon, 1601 (BIbliotheque Nationalo).

Allardroe N1ooll, The orld of Barlequin, Cambridge, 1963, 118. 89

10. Painting in the National Iuseum, Stolkholm, derived from a print in the Recuell Fosaend, showing "Il oapitan Cooodrillo", that is Fabritlo do Fomaxis, overhearing. CF. pp. $51-2$ and 249.

Ibid., 18 . 21.

11. Illustration of the set for the "Sirstere de la Passion de Valenolonnes" (1547), showing eoparate oomartments in a sinjle line. Cr. pp. 95 ff.

H. Doougds and S. Roymond, Le dóoor de thêtire on Pranee, Furls, 1953, D. 20 .

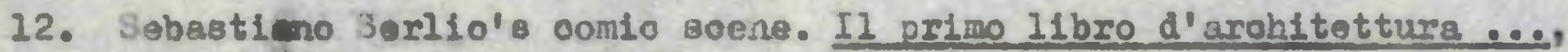
Paris, 1545, Cr. pp. 95 ff. Houssina, Le théâtre, p. 101.

13. The seatro Ol1pioo at Vlcenzs, showing fagade with use of perspective in convereinz alomente of the set. Cf. pp. $95 \mathrm{ff}$.

14. Wahelot's design for Rotrou's Los Ménochnes (soted 1631), showing doors and windows in tom houses. Cf. pp. $130-1$.

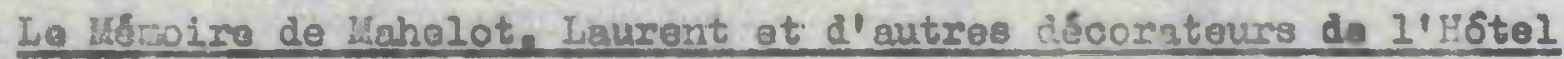
de Boursorene, Paris, 1920, p. 89.

15. Foodout fror the Recue1I Fosserd, no. XCII, Mationsl Huseum, Stocicholm, showing a serenade, in two parta with viol accompandnent (callod a "lire" in the text beneath the ploture). Cf. pp. 136-7.

W10011, The World of Harleauln, 118. 102.

16. Woodout 1llustration to Oxazlo Vecohl's L'Amfipemeso, Venioe, 1597, speolfying the epeaker of the prologue (British luseurs). Cf. p. 272 .

17. Toodout from the Recull Fossard, no. XIV, showing Herlequin plaving the bragisert $301 d 10 x$.

Wrooll, The Horld of Herlequin, 115. 99. 


\section{PREPAOE}

It 18 just over a hundred years alnoe Iimlle Chasles publishod his peroeptive and thorough ta comedle franselse de 18 Benalsasnoe. In that tine, both the Ilve theatre and drenatio oriticlom have adopted new approesches to Renalssence drama, and new facto have been made arailable. Wy alm here has been to re-exemine the texts and to orfer new perspeotives on Frenoh Fienalosance comedy. The fleld is a small one, on the froe of 1 t. But it is large enough to sugport valld conclusions moreover, I have osot no not wde,

To present one's work in unfiled form neans colling researoh temporarlily to is halt. But I hope to follow up certain espects further before tuming th1s thosis into a book; espocially the influence of Terence and his commentators, a subject which oannot be properly approsched without the sixteenth cantury texts \%. at hand.

3y tharks are due to no supervisor, Iofesstr I.D. Wofarlane, for his onoouragement and advice over a pertod of yearsi to the Untversity of $3 t$. Indrews, in partioular for grants from the Travel Fund and Researoh Fund, to the dermald Dramatic Suclety for Qlloxing to produce Ben Jonson's Alchemist for thems to numerous frlends who heve read parte of the manusoript and made their 
suscrestions; to Profossor H. Lainons and to Christine Paterson for her speedy ard efflolert typlng of the manuscript.

St. dnarems

Juno 1967. 


\section{IMTRODUCIION}

This book is about a nezleoted part of Irenah Renalssance dramas about comedy and the conventions of comedy, seen not only in a comparatively gmall number of regular oomedies, but also in translations and sdaptatians, dialosues anci hybrld farce-comedies, and In apects of other jenres such as tragi-comedy. It is a neglected genre today, and has been so for the past haif-century. For ungland, we have a number of studios, editions of separate authors, and an establiahed serios, the flevels Plays, which includes a full complement of comedias of the late 16th and enxly 17 th centurles, whereas in France, the excellent editions of Jodelle's L' Juzene by Professor 3almas, of Turnebe' Les Conteng by Dr. Spector, of the anonywous Leg Ramoneure by Professor Gill, are lsolated, and I know of no overall study.

yor this reason, I begin with a survey of ocmedy in France from 1552 to 1630 . The various genres that are concerned, different as they may be, and scattered as the evidenoe is, show a continulty in certain conrentions from the Plelade to the plays of the 1620'st to Cornollle's Mellite as well as to the frankly traditional Les ramoneurs. Foreover, throughout the period certain Influanoss, in particular the irrportince of the study of Terence in 
schoals and universitlos, rerialned constant. So that a certain pattorn may be observed in the relationshlp between drametist and audionce; and this first part of the study should begln to illuninate that pattern. Host of the faots in this flrst part are already knom, and I olein no great originallty for it.

It has been wuch arzued whather or not these plays were produced in their om time. It is my bollef that they were, and I hope to have produced some new evidence that this is so. ${ }^{1}$ Jut by nor this 18 something of a desd horse. And for the present purpose it is a rad herring. If a reader regards the plajs only a 11terature, the question is 1rrelevant. If they are regarded as texts for stago production, it 18 certain from the texts themsalves that the authors at lesst had in mind an 1 dea of the stage which taken in oonjurtotion with other hown oouross (prints, arahives, etc.) can certainly help to tell us something about atasing in the 16th oentury. Finally, tn the last analysis, on purely theoretical grounds, tho fat that a rork is, gritten in drounatic form is cortainly justiflcation enough for treatin; it as ouch. The secand part of the book is therefore ifiven to the guestion of stritns. The third and principal part of the book studies the 
conventions in the plays: that 1s, the constint festures in a relationahip between author and audience. Flrat the comic theory of the French Fenaleance is oxamined, because it was certainly known to every eduosted san in the Ronsissance. In 1577 Gerand de Vivro oould writes

Ants Leoteurs, chsioun sgaft desja blen que o'et [810] que le Comedie, pourtant ne m'aruseray à Is vous deochiffrer on co lieu of, à cause, qu'1l $y$ en a tant d'autres quil on ont falct mention. ${ }^{1}$

This knowledge of comic theoxy, feined primarily but not only through the study of Torence in schools and universities, will affect both the attitude of writers towards their plays and the reactions of audiencos (und readers) to the plays they an (and read). Plays, even dore than othar forms of litexature, depend for thelf effect by their very noture upon a two-way celationshlp betweon author and sudionce. To understand bow a pley works, you cannot afford to 1 gnore elther the audience (as literaxy critics may be texpted to do) or the dramatist (as theatrical producers may be tempted to do). Conlc theory therefore has its importance for the actual stage prosintetion of these plajs, and so I have given a separate ohepter to 1t. It may be pointed out here thet

\section{1 \\ Gererd de Vivre, Comede de la fidelité nuptlaie, invers,} 1577, Aux Lecteurs, f. 2v. 
dramatio theory in the Ronalssanoe is not as 1solated a form of criticism as aramatio theory could be in later t1mes, fron the 17th contury to today: in the 16th century a play was a "po'me" Ilite other forms of literature, end mach cxiticism not specifically dramatic was appliceble to It. Indeed, specifically dramatic criticiom in the Ronaissance consisted only of a kind of appendix to what the xriter had probably alread sald about 11tereture in General and therefore about drama as well.

Then the plays thomselves are examined under difforent espeots in twen: plot, character and speoch. Mhls division is puraly for critlcal convenience. In terng of production, it makes no sense, beosuse for an audience a play can suoceed or fatl only as a totallty, but for the purpose of studying the ocnventions it should be villd. "Plot" includes the divialons of the play (prologuse and ep1losues, sots and scenes), the parts of the plot (exposition, donouement and what lies in between), and their arrengement. The other two divialons cover the use made of character and of verbal conventions respectively. Then I have attempted to gurn up the use of conventions in general in these plays, their relation to dramatio and general literary theory of the tine, and their function in terms of actual performance.

The bcoks in which the external hlotory of French Renalssanoe comedy may be found are today long out of print or daal 
only with 1solated aspects. In the l6th century itself, trajedles were the more often written and published, while in theory, the senre of comedy took second pleoe to 1ts more elevated counterpart. Sinoe the 16 th century, oxitioal attention has been foctuesd rather on tragedy, consiciered as a more serious and worthwhlle Eonre, and Ilenaissanoe comedy has seldom amerged Into the limelight of oxiticlam, let alorie into that of the modern stage. In the encyolopaedlo theatre historles of the 17 th and 18 th centuries by the Brères Parfalot, La Vallièro, Leris, to. - the relevant entries are senerilly quite brief. The 19 th oentury saw the reprintin; of most of the oonediea, and two genoral eurveyes Binle

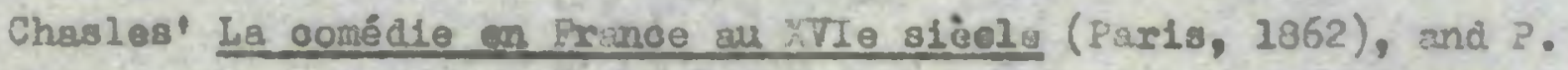
Toldo's "Ls condde frangaise de la Renalssanoe", oublishod in instulnents in the Revue d'histoirs litteralre de le erange, IV-VII, 1897-1900. The reprinte are variable in quallty. Chasles' peroeptive and enoyolopaedio mind produced a work typical of the beat of 19th century critioism, full of Ins1ght, olear and forthrigibt. But ho is too acoepting of the oritical notions of his times the central Idea behind hls book is an evolutionary ones from the enthusinstle but natre fropinge of the Plelade we traverse a dimly peroeived region before emerging into the full light of day with cornellle. Wo wro reminded, I think, of similar notions about the lyrio poetry of the tum of the century. Toldo covers the same sround, in greater 
detall, senerally with Chosles' faults but without bls qualities. Since then, as we shall see, excellent but 1solated editions and studies have appesred. One play (the only one that I have heard of) bas even reachol the modern professional atages Larivey's Les esprits, In an adaptation by Albert Camus made in 1940, acted in 1946 and remodelled for the 1953 pestival d'art dramatique at Angorg. 1

But since Chesles and Toldo, much has been discovered In reiated flelds, and nom approaches in oritiolam adopted. Sven Camus' comments on Larivey's play'ere seen to be quite misguided in the 11ght of recent work: "I' anclen frangais, les longueurs d'un texto qui so ressent de ses ori lnes improvisbes Les aeprits is tranalated from a oommala erudita, not a comala del1'arte], doux ou trols situations gretuites [only in teras of 20 th century drama] risqualent de falre oublier la richosse ot los inventions de cetto jolle comedle", ${ }^{2}$ wile the way in whion he uses Larivey in the flrst part of L'étst de 81ege (as "padro de Lariba") shows hi incorreot (though certainly fortile) conoeption of that author in terms of 1953.

1 Albert Camus, Los sprits, adaptation en trols actes, Par1s,

2 Ibld., Introciuction. 
Improvised camedy. Among the more importent work in related flelds are Professor Juokworth's study of lioman comedy, Jsogues Scherer's exchaustire study of the oonrentions of Frenoh 17 th century drana; hils study of Beaumarohals' comlo technique and J.B. Raterianla and 17.2. Irwin's equally olose study of the same author; MIss H.C. Bradbrook's study of the conventions of Ilizabothan comedy the works of P. Dachartre, Professor Allardrce Nicoll and therg on the oomedie dell'arte; and B.L. Joseph on Elizabothen acting. ${ }^{2}$ These, to nane only a fow, have ahown thet the time is ripe for a fresh a.prowah.

The convintions of French Renalssance comedy, 1 may be stated now, are sel lom orfiginal oreations by the Frenoh authors concernod. They derive especially from the commodia erudita of Arlosto and his sucoessors, from the coimpedia dell'arte, from Roman comedy, and to some extent from the farces, but they axe not Identioal with the conventions in those sources. For the rament, I am less interested in the preclse sources of individunl fentures

1

G.E. Duokworth, The natuce of flowan comedy. A gtudy in popular entertainment, Princetor, 1952 I. Jcherer, La drapaturgle classique en Irance, Pario, 1950, 1dera., La dranaturale do Besumarchals, Paris, $1954 ; \mathrm{J} .3$. ilatermanis and ... Irwin, the comic Strle of Begunnarohals, Seattle, 1961; R.C. Braibrook, the rrowth and Biructilis of Ilizbothar comedr, London, 1955, F. Duchartre, L8

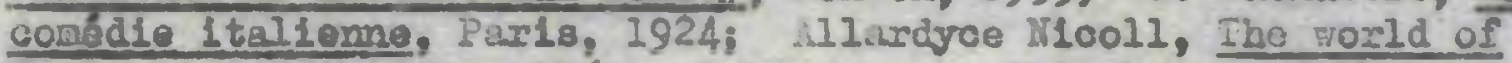
Harlequin, Cambili;0, 19633 3.L. Joseph, Ellzabethan acting, Oxford, 1951. 
then in tryin to establish what conventions were in use in Prenoh lionaissunce oomedy, and to judie thelr funotion and success in torms both of the practical staige and of literary theoly. Then this is cone, we nay better appreclate the genre as a whole - snd, more 1mportant, Individusl plays. Lify om respect for L'Dusione und Les Contens, for example, has gone up oonsidersbly in writing this study.

Certalnly the fact that the convantions are "unorifinal" should not affect any evalustivo judgament we may cara to make. The conventions, whether derivative or not, on the one hand enabled writers to produce varietions on en acoepted framework in exactly the same way as lyrio poets proto varlations on the acsepted Petrarohen frameworks of the time, and an the other hind in terme of staje toohni rue anabled them to achleve a particular kind of audience-relationship which would otherwise have been impossible. In the Renatesance, too, id do not belleve that there 1o any such thing an utterly conventional character or form of Gjeochs in every play, however good or bad the play may appear, the function of the conventions is to provide a basis for variation. A parnilel could be dram with the popular mulsio of the Renaisannce In France or in angland; we nover, or almost never, flnd simplo unolaborated versions of thome arms, or la belle triquotie, or go from Iny

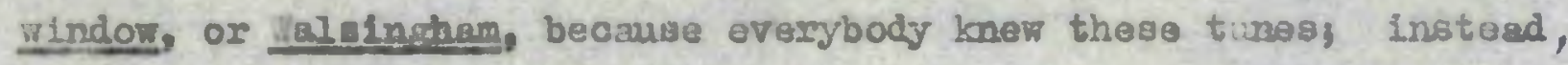


we find a number of different, moro or less olaborate uses nade of these tune in newly mritten oompositions.

Irench Rearlasanoe ocmedies are today $n$ ljoted. Yot they are not such infertor proiluctions as the space stven to them in literary histories would augersts certainly as good as of the Iyrlo poetry whoh is today the objeot of oriticel attention, and th the added interest, perhaps, of the dramatic form. The resson seems to be, to a great extent, the unrefuted accusation that the plass are derivative. On this charge, who in the lenalseance shall 'scape whipping? Du Bellay's sonnets, as is well knorm, are often translations, more or 1698 straightforward, from the Itallan. hy should dreme auffer an scousation no lonser levelled asalnat lyric poetry? Wober, Saulnier and othere hava shown how often speciflo 16 th oentury 1 yrio pooms, including some of the nost widely acclalmed, are aduptations or even translations of Italian models. Grahene Castor has enalysed the whole question in the 11 hat of llleas of plesiade theuriats ${ }^{1}$ - ldeas which are in fect concemed with liter ture in Ganeral and not merely with lyrio poetry. So that if we are able today to keep our apprealation of a Iyric poem independent of our knowledge of its sources, then we ought

1 Grahame Castor, Plélade poetiles, Cumbidge, 196\%. 
to be able to keep our approiation of a play almilarly independent.

Let wo see what kind of dabt 18 ored to their models by tio plays generally hold to bo liftativa Tumàbo's Las conteng and d'Ambolso's Heo loapolitain's. Edound poumler, in hla 1071 edition of Les conteng, HItes:

nulle part l'loftation n'sat próclse ns direote. Blle tourne autour de la oombdie de Turnèbe, l'imprì zane et 19 colore, mals ne la pénetro pas. 1

In his odition of 1964, Norman Spector carefully analyoes a number of analogues, of whioh the following is a typloal exsuples

Rodomont s Ge me consullles-tu, Mivelet? Dois-je endurer une telle brevade?

$$
\text { (Les contens, I, Ir) }
$$

Che 11 capitan Irasilo;o patira ohe gll sie fatta oatanta insturla?

$$
\text { (G.B. Della porta, LOlingie, III, 1v) }
$$

It may be a question of diroct borrowingi but quite possibly another Italian play, or some other source entirely, may be tho creditox. They are brassart soldiers speakings and the brasgart soluber is one of the most widespread of Renalssance coric fijures. Short of a close aratintion of the hunareds of extant 16th century Italian oomedies,

1 I. Foumier (ed.), Le thatâtre fransals au XVIe ot au IVIIo alècle, Puris, 1871, p. 91. 
the quation cannot be resolvod, so that it is senstble in most cases to speak only of "maja gues" and not of "sources". Even thore syeciflo borrowing can bo established, it is olour that Turnebe has recast the borxowed materlal for hls own play, as indeed one would hope and expect. Slavish borrowing simgly does not come into the question with this play. Les Neapolitaines, too, by Its very title, sooms to owe muah to Italy. Its Ifth century editor Bournler scain writes

- Ile dolt être su molns une initation assex peu déculséo de la comédie qui nous écheppe, et qui se retrouvera quelque jour. 1

But although we omnot exclude the possibility that a single olose sourca may one day tum up - that ies leapolitaln's may oven be a translation - It sams most likely that the play, like Les conteng, Is a transmutation of borrowed elements into a new sndividual oreation. It 18 certain that nuilve French eloments exist in its the character of Gaster is not the only reminiscence of Rubelais; the proverbs draw on a rich native stores while the pralse of Paris in aot $V$ is enthaiastic indeed.

There are, than, a number of different kinds of imitetion. Larivey was oontent with alterine Italian proper names to Franch ones. 1 Io1d., p. 132. 
The process whereby a nurber of different detalls are adopted from different Italian (and olssslogl) sources, 18 one stage further. This can be more Ieadily dono in comedy, a forr whloh beging with a wider perspoctive than does the Iyric poetry that Du Bollay was mainly oonoerned with. ${ }^{2}$ Iysio pootry ahieves 1 to offect prinurild through concentration upon a mail areas a play $1 \mathrm{~s}$ lanjer, has a different otruoture (aifforent types of linguese put into the mouths of a varioty of characters for drematio purposes), and moreover has to stand up to stajo presentation. That is to sav, thet numorically gpeakins a lyrio poom is likely to have a sizaller number of souross than a play. In a play, a oertain obaracter may oome from one souroe, the struoture of a scene from another, a particular tirade from another, and so on. The possibility of oomblnation is grester. And in frot we rind that there ere often a zreat number of sources used in this wayl for Tumbe's Los contens, Dr. Spector finds reminlscences and borrowing from twolve Itallan plays and a largo number of French and other ones.

The study was begun on the b3sis of those texts only which are strictly. oumedies and whlah are not close translations, niselyz

1 In his Deffence ot Illustration de la Lan Fere Franavao, 1549, Du Bellay makes only one roferenoe to the theatre. CI. I. .

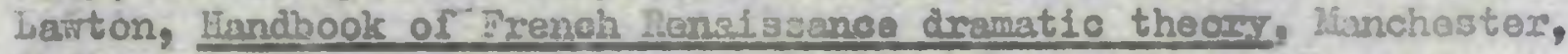
1949, pp. str. and 44 . 
Etienne Jodelle:

Jecques Grótin:

Jecques Grévin:

Reray Belleau:

Jean de la Tallle:

Plerre de Lariveys

Odet de Lumèbe:

Fringois d'Amboise:

Erangois Porrin:

Jean Godard:

Anon (Mlexandre Bardy?):

lexre Comallie:
L'Surène

ta. tresorière

108 esbahls

Sa reconnuse

Les corrivanx

Ses espritg and the other 61 int plavo; although strictly, all nine are close aciantations)

Les contens

Les loroolitaines

Les escoliers

405 issinisoz

Les retwoneurs

I.611te 1

These are comparatively fow In nuyber. But they still do not exinast the list of oomedies wittten or performed in France in the Tenalasance. Italian plays written, published or performed there are aurely part of the traaitiun, and we would be as wrong to 1fmora then as we would, be if we ignored, say, Pirandello, in the modern thastre outside Italy. Aso, somo ulasis are lost: tinus, Françols d'Amboise is sald to have written three oomedies bsildes Les Nespolitainos, but they do not survivo. ${ }^{2}$ It was found, too, that a study of conventions (as opposed to a mere historloal eximination of the plays ilsted above) simply culd not loave sulie certain other worke: certain translations, dialo,zos, or tragi-comedies;

1 pull cetalls of the dates of these plass rill be found in the bibllorraphy below.

2 See bibliography, sections 3 and 4 , for a list of comedios supposed to have been writion but now lost. 
foreign plays in France, Thare de Papillon's curlous Mourel2e

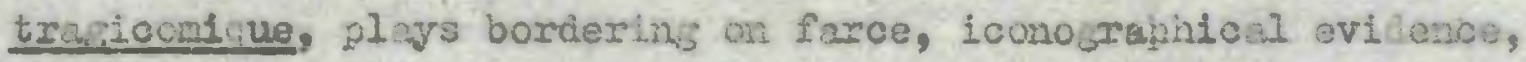
and so on. All these inply certakn kinds of morledje on the part of the audience or readex, so I have not hesitated to porex to then when it sooned deblrmble, to do so. On, the other hand, there axe oottain oomodies to which $I$ beldom refer: pierre Le Loyer's Dépholococume becuuse it is ifolated from the tradition, the only trunslation fros Aristophanes in the century; or Jeen-Antolne de Baif's Duruaue beccuse (unlike his Brave) it is so close a traxslam tion that French theatre traituon hundy conos into the quostion. londvey's nine plays would have overbalansed the stuid if all had been dealt with in detall, so in genorul Les esprits - which critical opinion since the l6th century seoms to heve decided, I think rightly, to be the beot of them - has been mide to staxd as typioal of the rino plays. Jarivey's reyutation showd in any osso not be allowed, as it sonetimes is, to obscure the real moxits of, 3ay, L' rutène or Les rononeure.

Exiating bibliograghies tumed out to be inalequate. In partioular, thore were frequent diserrbements on polnts of detail, espocially dates and bibllogrophicel niccties: franchs A'Albotae's Les loapolitaines, for example, exists in two aifferent timeng, a fact which one rould not gethor from modern bibliographichl sources. locution of coples, too, was a thorny proplean. Bo the bibliography 
at the end 10 a detailed one and should be a xel1able notroge of Iufura: on such points of doteil. 


\section{THE PLAYS}

\section{Plélade comedrz 1552-1574.}

When ItIenne Jodelle wrote L'Lugène, and when his contemporarles halled it as the flrst native french oamedy, three forms of the comlc theatre were already well known in Franoes the native farcen, the plays of Terenos, and Itallan comedies. The farces were still firmly allvo, though they had passed thoir heyday fifty years before, at the end of the 15th centurys reprints of the old farces st1ll appeared, some new ones were st1ll mpitten, and performances of them were certalnly knom both in faris and the provinses, both in Court circles and to the populace. Seblilet in 1548 wites of it as a flourlshing senres

Car le vrey suget de la Yaxce ou Sottie Frangolse sont badinages, ni zrauderles, et toutes sottles esmourantes à ris et plaisir ... Toute licence et lascivie y [dans les I.Imes ou Yriapées] estolt sdralse, come elle get aujourd'huy on nos irroes.1

In short, the farce was ons of the most tenacious of thestrical forms and was to flourish continuously side by side with Frenoh Renaissance oomedy. Te shall see how nearly all the fienalosunce

1 p. 165. Ant pootlque Brangors, od. F. Walffe, Par1s, 1932, 
oomedies show one or other of its features, 1ts oharacters, its partlourar kind of indeoency, its ootosyllabio metres though not Its shortness or 1 ts elmost complete disregard for considerations of time or place..$^{1}$ Perhaps by a plooe of conecloue antiquarlanisa, perhaps by the sheer maxit of the place, Pasquier's enjoymont of Patholin even in the time of the plélade was like S1r philip

\section{Sidney's enjoyment of Chary Chase:}

Je trouval sans y penser la farce de liajtre Plerre Patholin, que je lus et relus aveo tel contentement que j'oppose malntenant cet échentillon à toutes les conedies sxeoques, latines ot italiennes.?

- wille in 1583 pathelin was still on a raading list in prench ilterature drain up by Gabriel Chappuys. ${ }^{3}$

The plays of Terence, and itallan comedies, provided two

1 On farces in the 16th century, of. I $\operatorname{lan}$ Maxwe II, Brench farce and John Henood, lifelbourne, 1946, and blbllographys I. Levicks, "Wote sur un schôna de farce au XVe et au XVI0 slècles", 315110theque d'Eumanlene et Rensissance, XX $(1958), 569-77$; 3. Canninge, "Towards a definition of the farce as a I1teraxy genre", Modem Languere Forler, IVI (1961), 558-60 3 B.C. Bowen, Les oaractérlst lques esaent1elles de 10 farce frangatse et lour survivance lans les annáes $1550-1620$ (IIllnols studies in Language and Iiterature, no. 53), Urbana, 1964.

2 E. Paequior, Recherches de 1 a Erence, Paris, 1607, p. 1086. 3 L'avare oornus of chapter 2 below. 
further models at the time of Jodelle, one more Iltersxy than theatrical, the other only intermittent. Professor Lawton has liatod the remurkable number of editions of Terenoe in Irence in the 16 th century, a number duo mainly to hlo use as a set book in sohools and universities: his excellent Latinity as vell as his Iively dramatio style mide him especially suitable for the study of rhetorle as Fell as of other aspects of the dramatic art. ${ }^{1}$ Again, In French Renalssance comedies we shall see how elements of his plays are constantly used althoush his dramatio technique as a whole is nover slevishly liniteted, while as a basokround to 16 th century aramat1c productions the commentaries on Terence - by both Donatus and his 16 th contury followers - provide a ramarkably constant body of conventions. ? is for the Itallan oumedies, thelr performances in France at this time such as that of Bibilona's Ia Colandria in 1548 at Lyon, or of Mlamanni's Mora in 1555 at Pontainobleau were lsolated, and wo ahali gee how their influonec

1 H.T. Lawton, Ferenoe en Sranoe qu zVte slòole, Parls, 1926.

2 13. T. Herr10k's Consto theory in the S1xteonth Contras, Urbana, 1950, 18 a study laxgely based on the numorous and important 16th centuxy comentarles on Terence's plays; while 2.1. Robbins' D pamat10 Chargoterlzation in Printed Comantarles on Terence, $1473-$ 160 (IIIinols studles in Lanjunge and IIterature, XCNV), Jrbans, 1951, studies one chosen sspoct of Terence's work as refleoted in thes a same commentarles. 
does not become properly slgniflocut until the establishment of Itallan troupes in iranoe in the oarly 1570'8. Jodelle's L' Lugine beare the marks of this beokground. Froin the farce it takes its octosyllablo motre, 1ts satire on the olergy in the person of the self-incul cent Bugane, the oharaoters of the marl complaisant and h1s wife 71 th her esoy morals. From Ierence, Its IIve acts, the rather larger number of characters, the serlous nature of some of the speeches (such as Amaul's on the professions of scholar and soldier), and tho developed oharacterisation. From the Itallans, sg yet, nothing. In the last analysis, the essenoe of a play 1108 in what it 18 abouts and there can be no doubt that this olay is about the relationship of Allx, the wife, itth her easy morals, and Bugtne her lover the churchman; sbout a peril that threstens that relationahip and how the peril is aroided. This kind of Inmorel situration 18 not Terentian; but it 18 so typioal of farce that we are certainly justifled in regarding this play as essentially a farco elaborated by certain formal elements from Latin oomedy. I Why should this be so? In the serlous theatre,

1 M. Balmas, in his edition of I'Eujine, M1lan, 1955, gives greater importance to the formal elements guch as the use of aots and scenes and the observistions of the unitles, and states "Il seralt infuste d'on falre tout simplement une farce afrublese a l'antique" (p. 16). It is true that the observation of the unitios propresents a clear break from the extraordinary looseness of the farjos in th1s..... 
Jodelle was certainly an innovator, writing in the neiv form of olassical tragedy, which was utterly different from the non-oomio forms of his day. Here, he has accepted mach nore, disoarded less. A reason may be that the faroes were successful with all social classes in the thestre of hIs dey and 80 offered something of a suarentee of aucoess if Jodelle used them and simply added certain olasical olements. Again, theoretically, comedy is a picture of the life of ordinary peoples the flgures of, for instanoe, Gulllaume the simpletin or Amsult the enthusiastio soldier-soholar were doubtless considered suffialently olose to oontemporary society, without any attempt to adapt Terentian characters. An 4. Ch mard says, tho pley shows "un ourlour [b] of fort pour creer une comédle nationalo, inspiróo essentiellement de la réalité contemoraino". 1

Marty-Laveaux, writine In his 1863 edition of Joclelless works, oalls Ilueine "un des mellleurs ourreses de Jodellen. ${ }^{2}$ Be

... rèspeot. But thase formal elements cannot bo sald to outwelgh the basic subjeot of the play - what it 18 about - wich 18 certainly faroloal. p. 29.

1. Chamard, Flatolre de le Plelada, vol. II, Par18, 1939,

2

Les Curres at Keslanger Poetlaues d' Bustianne Jodelle, ed. Ch. Liarty-Laveaux, Parls, 1868, vol. I, p. 311. 
polnte out "des vers bouroux" and "quelques tralts de caractèn", saying though that it does not show "Io moindre talent de composition". Certainly the play 18 no masterplece of counlc structure 11k日, say, Jonson's Llchomist with 1ts carefully Interwoven strands: but it has at least a perfootly unl hed structure and in three ways shows a defindte 'talent de composition'. Flrst, the unity 1108 , us I have sald, in the appearance of a peril and In Its successful turning aside, without any lrrelevant action at all. inother virtue is in the character of Euberne: he 18 the only oharacter in Frenoh Renaisance comedy who develops in the oourse of the play, from reaklessness to euthoritative resouros fulness. And finally, the play is one of the fer in French Renalsaanoe ootady in which there Is no deus ex maohins and in which (whole action stems from the nature of the oharacters. Given the arrival of Floximond in act II (at the beginning of the action) and given the charsuters of the others, the ation follows naturally.

Li autere 18 the only surviring oomedy out of two by Jodelle, the other being La renoontre. M. Balmas, in his edition of L' together p1th the tragedy C16opgtre, at $1553 .^{1}$ The text of Ia

1 Ed. c1t., pp. 6-12. 
rencontre does not survive, but we know a little sbout its plots that 1 ts denourment conslsted of a froup of characters finding themselves within a sincle 'malson' or compartments and that elther in this play or in Cléopatre parts were played by Belleasi and Jean de 1a Perues. I The resounding ouccess of the performance of these plays is woll known.

The noxt comedles after Jodelle'B, Grfrin's La tresertere and Les eabahis, resemble Lisu:ene in tholr metre, st11l the octosyllables in their small scale and restrioted number of scenos, and In their 1morallty. Grêtin, like Jodelle a student at the Collègo de 3 ancourt, ${ }^{2}$ had his plays aoted in University ciroles, at the Collägo do Beaurata, in 1559 (La tresorièr) and 1561 (Les esbahlo). La laubertine $1 \mathrm{~s}$ probably alithlind comedy by him, now lost. ${ }^{3}$ Both plays were published in Le theatre de Jagues Grevin in 1561, and It seems that in 1567 be still thought highly onough of them to prepare a new edition, for a copy of the 1561 edition exlats with masusorlpt ohanges in his hand, appisently made for a new edition by

1

Cf. part II below.

${ }^{2}$ cf. H. Chamard, Histolre de la Plolade, rol. II, p. 5. 3 Cf. Appondix 3 bolow. 
the printer plant In whioh never appeared.

Grevin's interest in the theatre was wide. Baoh of the two comodies was performed together with other plays, La treaertìn proceded by the satyr-play Les vesux, Les eabihis by Les voctur and Grérin's tragedr Gésar - a dellberute attempt to reproduce something of the drametic performances of the anclents. And side by side wth th1s neo-classical andeavour, he shows a lonowledge of the theatre In his orm time, telling us in h1s Brlef disocum of the plays staged on moving carts in Mlanders in his dav. Finally, theatre lajaexy is used in a number of his poers, espectally in one sonnet of his

\section{Gelodecrye:}

Gi'est-ce de ceste $\nabla 10$ ? un publio eschafault, ou celuy qul spait mloux jouer som personnage, Selon ses passion eschangeant lo viseje, Est tousjours blen venu et rien ne luy défault.

... Alnal sourentes fols l'on volt sur un theatre Un conte, un duc, un roy à allle joux s'esbatre, St puls on un instant un savetier nouveau ...2

It way be partly because of this theatrical intereat that it is the plots that are the most attractive feature of $\mathrm{hlo}$ two conedies: they are restless, skilfully built up and unifled, especially in Li treagrlore

\footnotetext{
${ }^{1}$ Cf. bibllography, seotion 1, below, and f1.5. 1.

2 mortre complat at poéstes oholales, ed. L. Finvert, Paris,
} 1922, p. 316. 
with Its financial complloations, es though he vere most arare of this side of dramatic writing. Yls oharacters are less full than Jodelle's; hls language less oolourful than Selleau's.

Reruy Belleau, as we sar, acted in the first performances of Jodelle's Cleopatre and Le reneontres he was also to write verses for Balf'g Le brave. His own comody, La reoonnue, was first published In the posthumous collection of 1578, but in an spparently incomplete form, in that a number of the Iines lack a rhyme. Marty-Laveaux points out ten suoh lines in the $\mathrm{play}_{3}{ }^{2}$ four of them are lines onding a scene and one of them is the olosing line of the whole plays

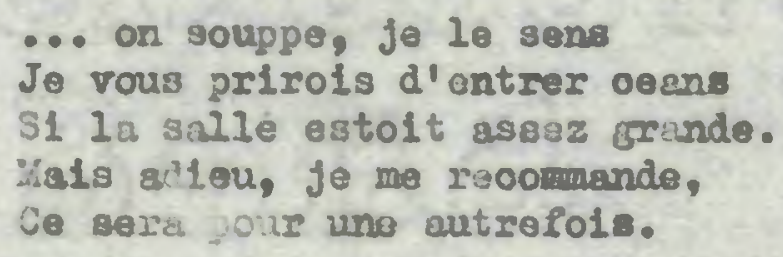

It may Indeed be, as the preface Ali leoteur of the 1578 odition says, that the play was loft unfinished, but it seens an odd process of composition whereby extra lines should be added for the saire of rhyme at a later date, so that I am inclinod to accopt the imperfoction as 1 stands.

The play 1s set in 1563, the year of the slege of Le Havre end a yoar after the slese of Poitlers, both of wich are mentioned

1 Lomy Belleau, Gurres Foetiques, od. Ch. Marty-Laveaux, vol. 2, Paris, 1878 , p. 483 . 
In the text. We may suppose that the date of composition, and perhaps of performance, is the same as the date of the action. In any case, the play must already have been old by the time of its first publication in 1578 .

La reoonnue's subject is actain reminiscent of farce; but nevertheless in one respect is nearer to Terentian oomedy than is Jodelle's play: in that Belleau gives us a much more unified picture of a bourgeois society. Jodelle's maxi complaisant and his wife, a churchman whose pleasures ure misic and hunting, and two soldiers fresh from the wars, are a varied collection and they give a piecemeal picture of their society. With La reconnue we are mach more clearly in a singie unified milleus that of bourceois men of law and their families. Honsieur is an adrocate, Malstre Jehan is his clerk; the young lover 13 also in the legal world. The young woman around whom the action revolves is, plausibly, ifonsieur's ward; Madame, the nei chbour and the servants discuss the problems of marriage and family Iife completely within the context of a closed circle. So closed is it, in fact, that the whole atmosphere is most successfully a claustrophic one, of sour discontent at one's professional or marital status, of selfishness, of determination to use other people to gain one's own ends: an atmosphere entirely different from the gaiety of nearly all other French Renalssance comedies. 
Balf's two plays, Le brave and L'eunuque, have tholr plece in the history of French Fenalsaanoe oomedy as adspatations from plautus and Terenoe rospect1vely. L'eunmene makes only small changes for stylistic purposes, and the proper names are only nodifled and not chanisod, Phoadris in the Eunuchus beoomes 'Pedrl jouvanceal'. It seeds $11 \mathrm{kely}$ that it was performod, perhaps at Court, for the manuscript noir in the Bibliotheque Fationsle bears the wards "Aahevée Lendemain do Nö̈l devant jour 1565", as though it were written for some Cloristins festivity. Le brave certulnly was so performed, as Its t1tlo-parg tello us:

Le Brave, comedie de Jan Antoine de $3 a I f$, jouse devant le Roy on I'hostel de Qulse, à Parle, le XCXVIII de junviex H.D.IXVII.I

Freoding or following the aoto were five chantz reciter entre les actes de la comedle', verses perhaps sung, and In honour of the fiogal famlly and whout conneotion with the subjeot matter of the plays a variant on the instrumental musio used for the same purpose In Jodelle's L'Huines

Wesmo Io son qui les actes separe, Comme je croy, rous eust semblé barbare,

S1 l'on eust eu la ouriosit

De remouliex du tout l'antlquité. ${ }^{2}$

1

J.A. de Barf, Le brave, Por1s, 1567.

2 I' virène, ed. Balmas, prolozue, 11. 69-72. On Barf's ... 
Le brave 18 rather more of an adaptation than 18 L'eumquas:

Plautus' Pyrgopolynices becomes Talllebras, Periplectomenus Bontams. The orfinal is sometimes out, soretimes anplifled, in the last scene of the play, for instanse, Tatllebras has a speach of fourteen lines in which he pulle hinself tojether ("Ay-jo au molns toute ma personne?") Fhich is not in Plautus and mu perhaps be a dellberate amplifloation of the brasgart captaln's part.

Jean de la Tallle is a flsure of tranaition between the PIs1ade and the more Itallunate generation which was to follow. One of his two oonedies, Le Nempmat, is a translation from iriosto, while the other, Lea coreivan, borrows 1ts plot from Boocacclo. T.A. Daley belleved ${ }^{2}$ that 1 t wa based mainly on Parabogco's II Viluppo (1547), to which if sertainly shows strong resomblanoes. It is also very simflar to Nardt's I due follal rival1 (1513). Tut both the Italian plave are certainly based on the fifth story of the fifth day of Bocoaccio's Decameron. And La Tallle's play lo mach simpler

... "ohantz", of. Helon Purkis, "Les Intermòdes à la cour de France",

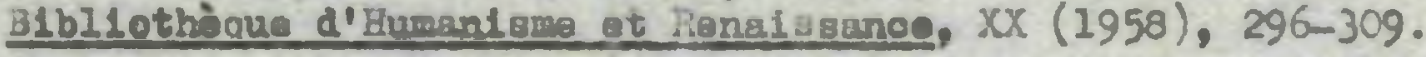

1 The susgestion is, of course, dependent on textual factors: It would be necessary to disoover preclsely what text of Plautus was arailable to Baff for translation.

2 T.A. Daley, Jean do la Taille (1538-1608), etude historiqua et littlraire, Par1s, 1934, Pp. 193-5. 
than elther of the Italian plays, so that it appears to be derived not from elther of the Italian plavs, but from Boocaccio, elther from the orlginal or from a Fronch translation. Tiro feotors confirm th18. Plrat, in La Tallle, the heroine $1 \mathrm{~s}$ reoosnised by a mark under her left gar. Nelther II Viluppo nor I due follel refoll hes trils, but it is the device used by Boccacolo. And second, In Le Taille the heroine bears the unusiral nawe of Restltue, a name not used elthor in II V1luppo or in I due follol rivall. Thle name adinittedily, iu not Boccaccio's herolne's name alther; but in the form Restituta, it appears in th Bucoeeding atory of the Decemeron, the sixth story of the fifth day. The play Itself may be dated at 1562. for in act II, soene 11 Fleurdelys ls oalled "une fllle foune d'un quinze ans", and In act IV, soene $v$ we learn that she was four or flve yeqrs old when the thanch army entered Toul (In 1552). Ie Neromant probably dates from the same perlod, when la Tallle and his brother Jacques were at the Univeralty of Paris and when we know that they both wote tragedies and comedies.

Le Jegreant takes 1 ta plece in the number of translations of Itallan comedes into Fronch, whloh had begun already in the $1540^{\prime} \mathrm{g}$

I Jean de la Tallle atates that his brother wrote "comase moy (relon lo vroy art, et la fegon antique) Fömes entlers, Tragedles et Cosodies, on 1 's 1572, f. 70 ). 
but Les corrivan is the flrst ori jinal French oomedy to be inspired by an Italian source. In this, ind especially in that it is a nondramstic source, La Tallle shows hls orlolnallty, fust as he did in his Sail le furloux, in shoring an individual variation on trudition. But despite Its Italian dobt, Los corrivaux (Iike Saij) is only a Viriation on an established tradition, not a breaking awry fram it l1ke Le Loyor's Nephelooocuste later. In its formal structuro, it remalns olose to I'Jugène, La trescriàre. Les esbahls and Ls reconme. It is short, it has few soenes\}. Its charcaters are few. It uses a farvical aituation whereby two sorvants find themselves at the same plase at the same time to give secret alpols to the two young lovers who have bribed then; but the situation 18 less developed than it ilf ght have been in one of the later Itallamate plays of the kind of Turmèbe's lues oantong.

To these varlous oomedies we may add three translations from the Italian in this early period. Charles Satienne's Comede

1 Cf. Daley, op. ait.3 A. "̈ernor, Joen de la Taille und sein Saiil le furleux, Le1pzis, 1908, pp. IVi-1Vi11. 
du 3acriflce, Lyon, 1543, has the distinotion of belns the flrst translation of an Italian comody into frenoh, and is taiken from GIIngannati of the Intronat1 of Siona. It proved popular enoligh to be printed In two further editione, in 1548 and 1556, though under the new title of Leg abusez. ' Jaques Bourgeols' Comedie tras alonate, en lacuelle sont contenues les Amoura reoreetives

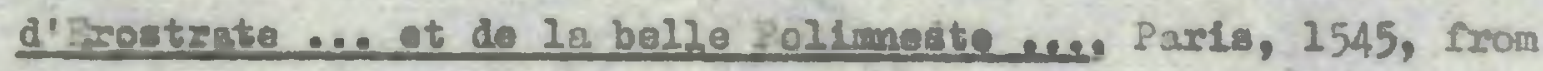
Ariosto's I Suppesit1, unfortunately does not survive, thoun the very preoision of the title, given by the Vallidre in $1768^{2}$, seems to shon that it did in fuat extat. Jean lerre de Hespes' Comedie des supposez, too, seems to have been sood doal less popurar than Hatlenne's play, in that the flrst odition (Paria, 1552) exists in a re-19sue of 1565, some thirty jears later, conolations of unoold coples of the firet odition provided only with a nev title-page.

It is surely remarksble that two of these three transiations, and La laille's Le Neverenant as woll as Godard's Les dob uilsez 23ter In the century, should all be from Arlosto, when very laxjo nutubers

1 The flrst odition 13 rare; a oopy in the Blbliotheque de I'Arsenal is ofted by lime Jomblionval, Traduations at adeptations frangríses du théêtre étranser, vol. 3, Parls, 1960, p. 70 . Cf. H. La Lan, "Charles Istlomo et le théatre", Rerue du selulème slècle, XIV (1927), 336-47.

2 Blbllothògue, vol. 3, Drosdon, 176e, p. 243. 
of other Italian oomedies were by this time in existence and in print. It 18 yet another oxample of Arlosto's grest popularity in Frinco in the 16 th contury in vaxious literary flelds, Including the related one of tragl-oomedy. 1

The whole question of translation and intation, of courise, has a partioular sisnificanoe whon it is considered in the oontext of the 11teraxy theories of the time, according to which transiation was a highly acceptable forn of literuxy endeavour. ${ }^{2}$ Thames Sobillet co:Id write in 1548, "La Varsion ou Traduction ost aujourd'huy 10 pöéme plus freyuant et mieus rooou des estimés fö́tes ot des doctes leoteurs ${ }^{3}$ and the example of, 8E, Amyot, and countless others throughout the century conflims this. The less direct form of Imitation was by 80 much the nore accoptable. Ju Sellay's 1 dea 18 woll known, thet the wittar ghould take over elemonts from his models

1 Gamier's Bradamante, the first aurviring tragl-oomedy, is from Arlosto 80, presumably, wes the lost La belle Genievre, pexformod at Fontainoblecu in 1564 (Cf. G. Cohen, "Ronsard et la thestre", "Mllemges offerts a Henrl Choinerd, Pirls, 1951, p. 124).

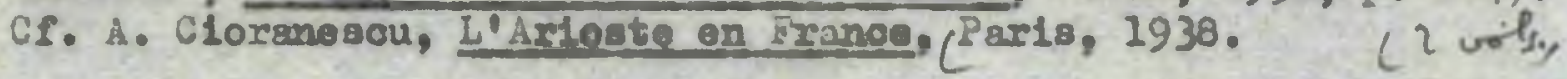

2 Cf. esp. Grahame Caktor, 161ade Poet10e, Cambridge, 1964, in partioular ohapter 6 'Imitation of model authors', pp. 63-76. 3 Art Fontlque Prangars, od. F. Gaiffo, Parls, 1938, p. 28. 
(who might be Greek or Rorran or Itallan), should assimilate them to beoome as It were part of his om flesh and blood, and then out of thes, once assinilated, should produoe his own works. hotual iltercil trenslation found less fevour in his eyes, though some of his ow poems are in fact almost direct translations from the Itallan. Sebillet, his opponent, on these srounds was able to scouse him of hypocrlay:

S1 je fay moins pour moy en traduisent anclens autours qu'on cérchant tinventfons nourelles, je ne suy toutafols tant a riopendre que celuy qut sa vante d'aroir troursó, ce qu'll he mot a mot tradult dés autres.l

But it rasined a fsct that tranolations and imitatione from the Latin and from the Itallen found sufflolent favour in Denalssunce eyes for there to have beon a constant stream of thein thoughout our purlod. For comedy perhass more than for other liteingry genres, the point is an lmportant one, and wo shall return to it.

The zenre of oomedy, they, has Its place in the Plsiade's literary activity. Fonsard himself seems to have taken part in 1t, for his blographer Clauid 3 inet tello us that he translated Aristophanes' ylutue while at the collège de Coguerot. If this were so, it and to Loyer's Nenhlococuale of 1578 would be the only. know

1

Goted from I. Chamard, Joschin du Bellav, Lille, 1900. 
translations of Arlotophanes into French in the 16th oentury. Brit it hes not ourvivod, and a Plutus is also attributed to Baff, who, as we kacw, tranklated or sdapted two Latin oomodies and has wall have translated this aleo. Without further ovilonoe, we cannot do better then sdopt $\mathrm{H}$. Lebèzue's injenious augeestion that the translation was a jolnt undertaleing of the two whlle at the Colloge de coqueret. ${ }^{1}$ - There are also other marginal connototlons of Monsard with the theatres the "ohant" which he wrote for Ba? $f^{\prime} \mathrm{g}$ Le breve, or the liking for faroe whloh be shows in the Blerte a Is Rovme of 1564 .

Guand volrmons-nous sur lo haut d'une sciene Quelque Janin avant la joüe pleine Ou do farine ou d'anore, qui dirs quelque bon not qui vous ré jotira? ${ }^{2}$

In the time of the Plelade, ten comedies at least were writtens two were performod st court, which was not 8 small sohlevement; Belleau and Jean de la Parrue sctod in the performanoe of La remoontre with Cléonatre; jitlenne Pasquier, Jean Vauquelin de la

1 Tableau, p. 301. Gustave Cohen, in his "rionsard et lo thøattre". p. 123, sujsests that the translation was neithor by konsurd nor by Baff, but by Dorat. Cf. lso Ronsard, Gurres complètes, od. P. Lewmonier, VI, p. 462 and $n$.

2 Qurres oorsolètes, VIII, p. 148. 
Fresnave and Trumcle (father of the author of Is oontene) Sar the performanoe. Verse for le breve was written by Vasquin Philleul, Ronsard, Selleau, Desportes and Barf himself. It is no exasteration to say that at th1s early period, oomedy was a genre that owed its existenoe almot entirely to the students of the Collège de Boncourt. flrgt Jodelle, with his follow-students Bolleau and Le Peruse as aotors; then Belleau himself wh1le La Tallle and Grivin both otudied there. ${ }^{2}$ ifuret and Buchanan, both teaching at the Collège do Bonoourt in the early $1550^{\circ}$, may pexhaps have encouraged this produotion, though they themselves smote tragedies anly and not comediez.

Ten plays are not many, in a pexiod of twenty years. Italy was produoling far larger numbers of comadtes at this times so was ingland, fifty yoars later. The number of the oinedies is not so lmportant as their qualities; but st1ll, we may ask why there were so few. First, it is oertain that the comlo genre was less highly rated than the traglo, as we shell see when we oome to examine comlc thooxy in the Renasasances It dealt with bourgeols rather then nobles, it showed comparatively txivial matters for entertainment rather than h1gh morsal ones for edffloatlon. Joubtless Terence was

1 Cf. H. Chamard, H1stolne de 1 s Plolode, rol. II, pp. 5-3. 
highly esteemed; but it was for hls rhetorioal gualities and not for his moral ones while authors 1 ike V1rgll had their share of esteok. Second, on practioal groundss of all ilterery worlics, plays cannot exist only an the printed pages they noed a theatro and a wholo theatrioal tradition. The Plolade goneration had only fellor-students to use as actors, necessarily amateurs without any establishod tradition. The living theatre of the time had only trivial faroes as a comio zenre. These authors, then - Jodelle, Grerin, Belleau, La Tallle - were faoed with a choleo of a living theatrical tradition in the farces, or a University milieu without permenenoe or experiences and all of this first generation seem to have trled to oreate, and to have sucoeeded in crating, a fusion of the two. But thay st1ll lacked theatres and actors; and practlcal reasons of this kind doubtless partly explain the mall number of comedies written at the time of the Flelade.

\section{Italiamate comedva $2572-88$.}

In the late $1570^{\circ} \mathrm{s}$, a nov poriod begins not only in the history of comedy but in the literaiy scone as a wholo. The Itallanism of the tive of the Plelade, that by reaction had for a time beome less ovident in Frunce, now roturas in a different way, and in strensth. Translations and adaptations of Ital 1an worice appeari Italian muslo and Iiteriture become talking polntas and 
In the thestre particularly, the oltuation is completely ahangd by the enormous suocess, hitherto only sporedio, of the trivelling troupes of Itallan actors.

The translatlons and adaptations are leglon. One of the most proliflo witers was Gablel Chappuls, who by the sheor volume of his work and the kaleldosoope of his interests resemblos the other writers of comedies Plerre de Larfroy and Irangols d'Ambolse. The full strean of his literary produotion is around the late $1570^{\prime} \mathrm{s}$ and early $1580^{\prime} \mathrm{a}$ - precisely the period which concerns us here. Itallan litorature concerns him most of all. One book in partioular interesto us heres the 1583 edition of his translation from Antonfranoesoo Don1's I Iondir Les mondes coloztes, terrestreg et inferneux ... Mirez des aurres de Doll Morentin, par

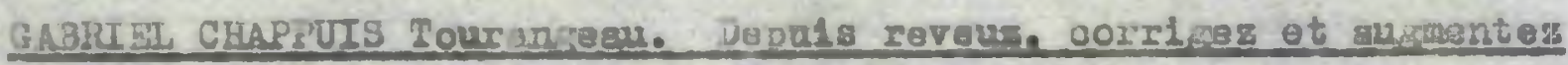
Au sonde des Cururoz ... par F.C.T. [Francols (?) Chappuis Tourungeau], ? Lyons, Barthelom Honorat1, 2583. I Honat first publlshod in 1552 , wo a collection of dialosues, Luolanic in form but without Inolan's tronohant wt, adopting a varlant of Luolan's Vera Historla: a satire on this world by a supposed description of another. Chappuls first

1

Both the 1583 and the 1580 editions (see belor) have "E.C.T.", but there is no doubt that the worls as a whole 19 by Gabriel Chappuls. 


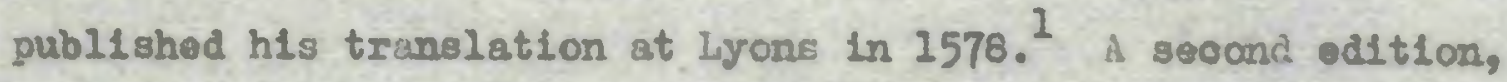
of 1500, claing on the title-page that the Mondes are here "reveuz, corrigez et augmentez du lionde des Cornuz par F.C.T."; but in fact they are no such thin:. The yoade des Cormen firet appears in the 1583 edition (though 1ts existence earller my be prosumed fron the rontion in 1580), and it includos a oomedy, L'avare comenu. Te are to lmaglne the situation of the prolosue to The Beaser's Opers: to prove a polnt (In this case about ouckolds), Le Poëte takes le curlaux aslde and has a play acter beforo hims

\begin{abstract}
Je vous foray sortir maintonant quelques personngres quil vous demonatreront par is Scene Conlque une autre raniere de cormuz que vous ne ponslez at rous foront toucher au dolst ce que jo vous nye [sic, "dre"? ] car la chose representée au oif ainal qu'elle ha ente faite, ha plus d'energle ot d'efflosce, que ce quil se deolare par paroltop.2
\end{abstract}

In between the five eots, and after the play, thore are discussions betwoen the two onlookers. Ihla play, Ilavare oorzul appears to be an original crestion by Chappuis - so, indeed, does the whole of the Monde dee corsus - a polnt whloh I have never seen sufificiently made

I Les ropaes celeuteg, torrastres ot Informoux ... IIrez des curres de Doni Florcatine par Gabriel Chappule Touranceau. Lyons, Barthelomy Honorati, 1578.

2

1583 odn., p. 666. 
clear. I No edition of Doni that I have seen Includes an Italian original of this section, so that Chappuis in fact appears to have appended his own original contribution to his translation. The title-page of the 1583 edition is in fact ambiguous: "reveuz, corrigez et augmentez du lionde des Comuz" could mean that Chappuis was the author of the additions, or merely that he was adding more translations to this 1583 edition. But in view of the absence of an original by Doni, and the very traditionally Frerch nature of the play, it is most likely that the play is by Chappuis. The play itself reminds us of the earlier generation in Its combination of farce elements with modern ideas of the comic 1deal. The avant-ieu repeats some of Jodelle's claings

Vous orrez l'antique sujet Et non le stile trop abject Des basteleurs qui veulent plaire Tant seulement au populaire. ${ }^{2}$

1 In his artiole "L'avare de Doni et L'avare de Nolière", Revue d'Histolre Littéraire de la France, I (1894), 38-48, inile Roy bases literary judgements on the unfortunate assumption that Chappuis' play is necessarily a translation of a play by Doni, existing but not found by Roy. Toldo, five years later, in a footnote to his "La comédie frangalse de la Renalssance", ibid., VI (1899), p. 571, attributes "une oertaine originalité" to Chappuis in the seotion Le monde des comus.

2 1583 edn., p. 669. 
The play 1teelf, like I' Suking, has five sots. But there are fen other classical eloments: Iike L'Busène, its simple plot derives from the faroes (a viotilard amourew and his amorous adventures) and 1ts netre is octosyllablo like the farcos'. Only by its Inclusion in a tranelation from tha Italian does it proplde a link with the new generation.

One of the more interesting gloures - though his oomedy 18 unfortunately lost - io Hieroamo d'Avost. In 1583 he published his Babals de Hierosme d'Avoot. de Laval. sur 109 eonete du dirin Potrargua, a Blin book elofantly producedr essais not in Montal gne's sense or in ours, but experiments or attempts in translation. The sonnots are fer in number out thoughtful in teohnique and presentation. D'srost hes a more than aoaderio interest in translation and its groblemes the dedication discusses the ways in which he lo naturalising Potraxoh, while at the end of the book, for comparioon with his orm versions of the same poems, he prints four translations of petraroh sonnets by other poots: two by Vasquin Philieul of Carpentres, and two versions of Hor che'l olel .... one by PolEotier and one by fitlenne du Tronohot. D'Arost's interest in the Italians extended to comody. La Crolx du llaine reports ${ }^{1}$ that he has made a translation from Louls

I La Crolx du Xlaine, 3 Lbllotbiau frangolea, Paris, 1584, [1772-3 edn.: ] I, 373. 
Dowentohi, culled Les doux courtisanes, which 18 now (1584) ready for publiantion. As far as we know, it never eppeared, and $\mathrm{L}_{2}$ Crolx du liaine!s is the only evidenoe that we have wbout it. That should pe rellable evidence, however, for d'Arost's book actually contains a sonnot "A lionsieur de La Crolx du haina, sur sa s1bliotheque". ${ }^{1}$

The pattern of Chappuis' and d'Arost's aohlevement an interest in literary creation, largely based on Itallan modelB, Fith a bias towards translation, and an interest in comedy sa one part of that creative activity - is on a small scale a pattern typical of two of the other known comlc mriters in Frunce in the $170^{\prime} \mathrm{s}$ and $\cdot 80^{\prime} 8$; Plerro de Lexivoy and Irangols d'Aabolse. It seens 11kely that odet de Pumèbe, too, had he lived, al ght have written in the arme pattem, for his one pley, Les contens, shows him to have had a oloser knowledgo of Itallan literaturs than a mere passing intorest could account for. Tho philosopher Glordanc Bruno, visiting firlo in 1581-3, published his ccmedy thexes it may gell have been Trenoh Influences of this kind that inspired him too to proiuce this side-produot of his other very diffebent works.

1 In the Boesies appended to the 38sale (but dated 1583), f.11. The poen by Philieul provides a link with the earlier ceneration of comio writers, for as we sas Philieul was the suthor of one of the "Chantz recltez ontre les aotes de le comedie" of Balf's Brave in 1567. 
Plerre de Larlvey fits the pattern olosely. Hlo plays are not the lsolated products of a single enthusiast for the Itallan theatre, but rather fit into the variegated literery produotion, of many different kinds but alrays Itallanats, of a oirole interestod In the same kinds of models and I1terary teohniques, producing the same kinds (and the same volume) of works. Larivey's interests were as wide as any? h1s luits facetieuses are translated from Straparola, the Fllogofle fabureune from Hilrenzuola and Dont, the Philosophle at Institution rosele from \$locolomind, the Fumantte de Josue-christ from Aretino, the Veilloe from Amigto. His 19 th century editor Fournier saw him as a Renaissance Jeleyll and Hydo, tuming now to sacrod worka, now to profune ones ("upròs cette débauohe de traductions condques, où la déeonce svalt eu fott à souffrir, notre ohanoine trouva bon do ee purifler par un peu de philosophle et de plêté ... lui-même vivalt, malscé le contraste de ces ácrits ol môlás, avec toute l'salfication d'un chanolno honnête et pratiquant"). ${ }^{1}$ Cortainly a glance at Larivey's comelies will show that they al ght well represent ono side, in moral terms, of such s charsoterisation. For us, we need only regard him, I think, as a man of wide interests; and if ro place him in the context of the group in whloh he moved, we can 880 that these wlde interests are in fict typical of the whole groups lisivey,

1 Le théftre fronea is au XVIo ot ou XVII alèole, Pexis, 1871, p.56. 
d'Ambolse, Chrppule, d'srost, Gabrlel Le Breton, an others connocted Wth the group even if not authors of comedies such as hangols de Belleforest or Bbroalde de Verville: a literary ooterle who unlike the Clnq Autours left no colleotive works, and who unllke Madsme de Ramboulliet's friends left little direot evidenoe of aotual metings, but whose frlendehip is shown by a whole abries of 1 imlnuy verses (to be found In numbers in the pages of Laohovre), by dedications, even sometines by "L'Impsimeur au Lsoteur". I The most oonstint of their preocoupations was an interest in the literature of Italy. 411 nine of Lurlvey's comedies - Indeod, all trelve, If wo include the throe that wore not evontually published - are dodloated to Rrangois d'Ambolso. The frlendahip between those two was a long ane. As early as 1573 a somnet by Larivey wes included in a rork by the young d'Ambolises Lis Holome, ${ }^{2}$ wile the dedication of his second collection of plays, in 1611, 1s nogrly forty joaro later. It

1

For instance, the Intriguing note by the printer of d'Ambolse's

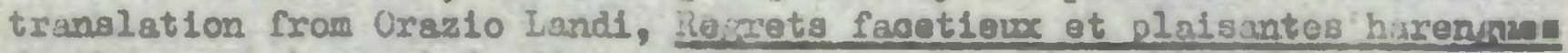
funobres sure la mort de divorg animanx, Paris, H1colas Bonfon, $1583:$ that the translation was orliginally to be made by Frangolo do Belloforest, who howerer passed the talk on to d'Ambolses that d'Ambolse had accepted it as an honour, al thouzh extremely occupled with joumeys to Gernanay and Italy.

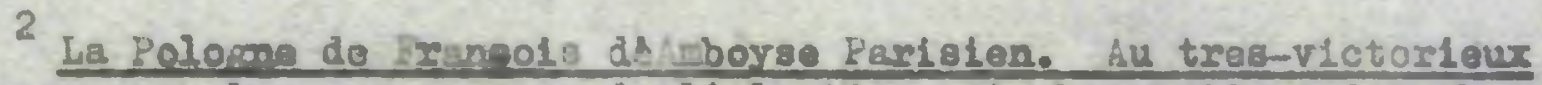

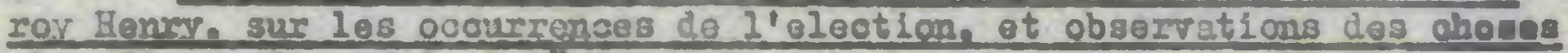
glus dirnag de memolre velieg par l'authour on con vorece. Lí diverses Ianues. Parli, Idenis Du Pre, 1573, r. 10r. 
is diffloult to discover precisely what tholr relations were. Larivey, thoush a canon of Troyes sho at least to hards the end of his ilfo is known to have performod his dutles in residenoe at mroyes, implies in a publleation of 1580 that he has served Pardeosus, "oonseiller du Roy en la cour de Parlement de Parls", in somo caproity for tienty yoars. This, presumably, in Paris. D'Amboise, though from 1581 to 1585 and again in 1589 a member of the Parlement at femes, does not appear to have exercised his office there, ${ }^{1}$ and to judge from his wany publications in Perts remained largely in that city. Somothing of a clue is provided iy the aare publication of Larivay - Plocolomini's philosophle at Institution morale - In whose dedication Larivey writes to Pardessus, "ce grand politique P1ccolominl ayant apprins lo lunge frangolse on rostre maison ot ì vos despens". This seomis to meen that the tranalation was made in Pardeseus' house, presumbbly while Larivey was in his service in sope oupacity, and at a time when d'Ambolse and Pandessus were professicmal collesgues. It should be noted that not the least of Plooolomini's many works is the comody Whlessandres there is more than the ordinary family likeness of any two Ranalsaunce bragerts between Plooolomint's Captain Nhilaolgt

1 Cf. F. Saulnier, Le Parlement de Broterne 1554-1790, R.omea, 1909, p. 26. 
and d'Ambolse's Jom Jieghos, while Dx. Spector sees in number of resomblances between the plas and Iurnebe's hew ocatens. ${ }^{1}$ The connootion ith d'Ambolse is strensthened by a tranolation whioh d'Ambolse made from jot another of P1000lamin1's works: the Dialowas at devis des davolselles. whloh went through at least four editions by $1583 .^{2}$

A colleague of a'dmbcise, though younger than he, wao Odet de Iumebo. Tumèbe died in 1581 at the aje of 29, and anly one mijor work of his survives: the comedy Les contens. The play wew published in the sane year (1534) as d'Amboise's Les Jecpolitines (though both pleys are earlier); the Itallanate nature of both plays, the readin which both presuppose, the use of the comlc, are so strikingly similur, that some connection between the two men

1 Odot de Turnèbe, Les contens, od. N.B. Spector, Peris, 1964, pp. 146-167.

2 I have seen two editionss Paris, Vincent Normand, $1581_{3}$ and Paris, Robert le liancnier, 1583, two Lyons editions, one without date and one of 1583, both Benoist ligand, are oited by Meudrier,

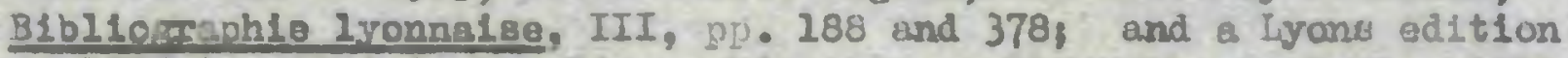
of 1577 is olted in tho Blosgaphle universelle, rol. 2, Parla, 1811, p. 25. 
seems likely. One would expeot it in any oase from the profesaional 11nke. And the soolety in whioh both men moved - legalistio, Intellecturl, Itril anste - a amall one. Pardessus' house may well hure entertsined theso two cis well es Larivey. Siooolomini's oumedy I'Alessendro, as we saw above, appears to have bean lanown to Tumber, whlch would flt in with the translations from that author mede by both d'Ambolse and Larivey.

D'Ambolse's play, Les Despolitaines, is the only survivins comedy of hil out of severul which he says were acteds "veües et receuës aveo un indiolble plaisir." I La Crolx du balne seys that he wrote four comdies in all. This one 18 lively, entertaining, though probably less suocessfur than his friend Odet de Turnobe's Las contenss Professor Larton calls it "undoubtedly one of the best of the century". ${ }^{3}$ It borrows fron tro main playss Terence's Eunuch and elther the Olimpla of Della Porta or the Anoelica of Fabritio de Fornaris (the Ankellos, wo we Bhall see, 18 simply a reworking of the 1584, f. 2 .

Frangols d'Ambo1se, Les liespolitainge, Par1s, fibel I'Anjeller, 2 Blbliothoque rengolse $[1772-3$ edn.], I, 201.

3 1949, p. 83. 
Olimpia). Neither of these two last plays, however, was published before Les Neapolitaines, so that we must assume thther that d'Amboise knew a manuscript copy of one of them or that he saw a performince, whether in Italy or in France. Moreover, he mast . ve gained his lenowledge of one or other play well before 2 December 2583, the date of the privilege of his om comedy. We know that the hrgelica was acted in France in 1584, before its publication in 1585 (Fomaris refors to this in his dedication, as we shall see), so that it may well be that it was in faot also acted thexe oven earliex, that d'Ambolse saw it and used it for his play. Fornaris tells us that he has had the model for his play - that is to say, the olinpla In his hands for some years, so he may well have used it for noting purposes before 1584 .

Les Neapolitaines is today one of the rarest of 16 th century books. I have triced only two coples, both in the Bibliotheque de l'Arsenal in Paris. A slicht bibliographical point arises the two copies, although both of 1584, are not identical. The titla-page of one describes the play as 'frcecleuse', the other as 'fort facecieuse',

1 Bayle called Les Neapolitaines "Ia traduction d'une comédie italienne" (Dictionnaire historique et critique, 3rd edn., Rotteriam, Mlcheel Bohm, 1720, I, 175); its 19th century editor, Foumier, wrote that it mi ht indeed be a translation, like Lisivey's plays, and that an Italian original forit might one day turn up (Le théâtre francais, p. 132). Is yot, none has. I hope to examine the question of sources more closely in a new edition of the play which I an preparing. 
an alterstion which has nocessitated changing the setting of the types and the privileges differ. ${ }^{I}$ poselbly two impressions are concerned, or possibly the differenoes were introduced by I'ingeller, the printer, in the course of printing.

In preolsely this perlod - in 1582 - one of the masterpieoes of Italian comedy was published In Paris: Glordano Bruno's Il Candelalo. ${ }^{2}$ Critics are unanimous about the exoollenoe of this play, which is nevertheless the philosopher's only dramatio mork, for Its liveliness and $\pi$ It and for its use of the drematic posalbilities that the genre of comedy offers. We know that Bruno was in Parls from late in 1581 to (at latest) June $15833^{3}$ the activity of the Irench literary olrele there which we have Just discussed, as well as the popularity of the Itallan sotors and Itallan theatre there mas havo prompted him to publish - indeed, perhaps even to compose - there rather than In Italy.

Ithin our perlod, two trinslations of Il Candelalo were

1 For rull detalls, seo the bibllography below. Cf. fig. 2 . 2 Candelalo ocmedia del Bruno Nolano Aohademioo di malla Aohadenis detto 11 festidito. In Triatitlo hilario in Hilaritato

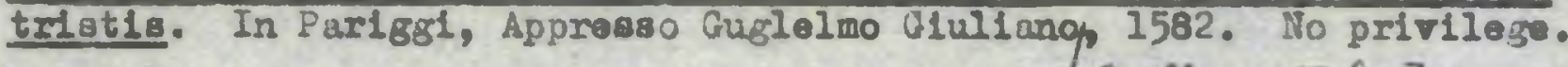

3 [Gutloume Jihen]

Cf. Pranoes Yates, Glordano 3 runo and the hermatio tradition, London, 1964, pp. 190, 202-4. 
made Into Fronch. One was printed in 1633 as Bonifaoe et la Pédant, ${ }^{1}$ one is still in manuscript, in what is probably an early 17 th century hand; $^{2}$ both are anowymous. The first 1a a poor effort indeed. Its athor writes, in the preface Al lectours

Coux quit l'auront louë [II Candelato] on son orisinal, recognolatrefont alsément combion de choser il m'a falu rotranohor, et coux qui la regarderont de prez, telle qu'elle sort de mos mains, se douteront bien combien 11 en a falu changer. Les iuthours quil s'attachent aux nalvetez de lour lanjue, et awx particularitez de lour nation, comne font principalement les Comiques, sont plus à imiter, qu' is traduires une trop grande fldelits m'out rendu ridlcule, - t c'eust esté proprement on oette oocusion qu'll se rut fait des v10es Frangols, de vertus estrangeress Tu ne trouveras dono pas tous jours loy les mosmss choses, quoy que tu trouves le mesme subjet, non 108 mesmes roncontres, quoy que de semblebles, mals plus modestess on un mot, si quelque liberte, du moing point de libertinage. Adler.

Thls is no proud atatement of confldence in one's native language and the consequent necessary teohniques of lmitation, such as we wight have found at the timo of the Plelade, rather, prinolpally, a statement of puriflcation of offending passages, which in the case of a

1 Boalfroe et le pédent comedle en arosen Imitée de I'Itallon de Bruno Volano. Paris, Flerre Menard, 1633.

2 Cf. bibligsraphy below.

Bibliothoque Nationale, WS. Pr. n.a. 2879, fr. 226-240r. 
play like II Candelalo is as absurd as Dr. Bowdler's onterprise, and as unsuocossful. If wo examino the text, as we axe lavited to do, we find that it is a out rather than an altered version of the original, and we also find two other curlous facts: flrst, not all the passages which might be considered offensite have roally been removed and second, oertain persages which seem to us todas theatrioally lively and morally inoffenoive, have gone. Thus, the play on asint and animi in I, 111, remains, Bruno's text readss

Bartholomeo. In queato teupo s'inamoró 11 Petraccha, et Gl'asini anch'essi cominclano a'rizzar 12 coda.

Bonifacio. Come harete detto?

Burth. Ho detto ohe in questo tempo se inamord 1 I Patrarcha, ot gl'animi anoh'essi si drlzzano alla contemplatione. 1

\section{And Bonlface ot le Pódrnt:}

Bartholomee. Ce fut justement en oe temps-lì que :etrarque devint amoureux, et c'est auust on oe tempg-1: que les asnes conmencent à dresser la queue.

Bonlface. tue dis tu?

Barth. Jo dy que ce fut justoment on ce texpg-1i que Petrarque devint aroureux, et que c'est aussi on ce teraps-li que les ses dressent ì la contemplation.2

A Iively passage in I, 11, where the oharacter Boniface refers to, andindeod quotes, a poem by the "lohademioo di nulla Achsderla" -

1582 odn., f. 4 verso.

2 P. 6. 
Who 18, of course, Bruno himself - disappears. So does the eurusing note in the Arjumento on the three prinolpal elements in the play. ${ }^{1}$ The mamusoript version, in the Blbliotheque Nationale, probably of the early 17 th century, 18 a dicferent trenslation from the one printed in 1633. For exaple, the play on asint and animi referred to above 18 translated as follows:

Bartholomeo. Dans co tempo la petrarque devint anoureux ot

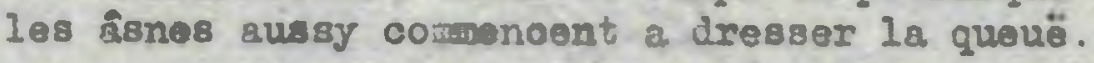

Boniface. Corment aves vous dit?

Barth. Jay dit que dans co temps la petrarque devint atoureur ot que les ["esprits" struck out and "ames" substituted] ames aussy ["se dressent" struok out and "s'elevent" substituted] s'elevent a la conternplation.2

But it soome to be a mor or lose Olose transiation of Bruno's ple and although it is intoresting that it ahould have been mado, this stralghtforward translation noed not concern us here. There appeare to be no evidenoe which might comneot it with any specifle person or troupa.

Ith the Anzellea of Fabisio de Fornaris, we return to strlotly staje history: the Itallan troupes in Paris. A very full 00.1lection of documents published by Axwand Baschet In 1382 atill remalns the essential referenoe rork; little ner ovidenoe has been
1 cf. oh. 6 below.
2 3.4., WS Fr. n.d. 2879, i. 226 verso. 
discovered since then. I from hls book, and from a study of the French theatre as a whole, it is clear that the success of the Itallans in Parls from 157 onwards was of capital importance. The Geloe1, the Confldenti, the Raccolti, their success and thelr Influence are undoubted even if our knowledge of their repertory and even of their names is limited. One lmportant text in that ropertory is Pornaris! Ancel10s. 2

Fornarls was the leader of the Confldenti and a gneolalist In the role of the bracieart aoldiex, that sure ouooess an the Renalssance stage. As the braiggart soldier, he oalled hinself "II Capitano Coocodrillo". John illot probably saw hlm ill Parls, and he included him in one of the dialosues in his Ortho-epla sallio, London, $1593 .^{3}$ We oven have a oontemporary print and an oil painting

1 Les combiens 1taliens i la conr de Brance sous Charles IX, Henri III. Bmer IV et Louls XIII, garis, 1882. The Influonoe of the Itallars on Fronch comedy has been discuseed in throe recent artiolesi

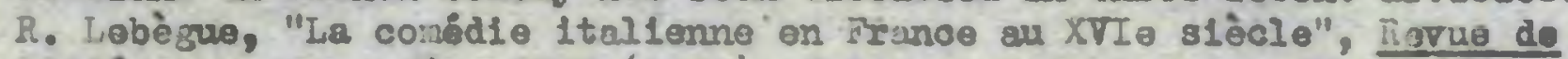

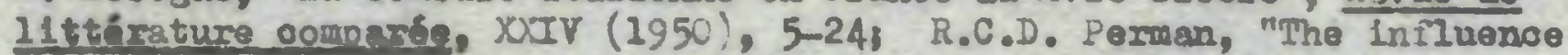
of the conmedis dell'arte on the renah theatre before 1640", Branch Stulies, IX (1955), 293-303, N.3. Spector, "Odot de Iumebo's Lee contens and the Itallan comedy", Frenoh Studiee, XIII (1959), 304-313.

2

Anselloar comodla de Fabritio de Pornaria Mapolitano detto 11 Capltano Epooodrlile Conice Confldente, Paris, Abel l'Angeller, 1585.

${ }^{3}$ Cf. Frances Iates, A gtudy of Lore's Labour's Lost, Cambridge, 1936, pp. $50-72,163,177$. 
of hig in his role of Coocodrillo, 1fving up to the thunderous captain of his play. ${ }^{1}$ Anvelica, in which the captioin is called Cocoodrillo, is a reworking of the comedy olimple by Giambattista Della forta (In whioh the oaptain lo oullod Trasilogo). Formaxis says in the dediostion to the Due de Joyeuse (In whose house he says It was acted) that it is baded on a oomedy given him by a Neapolitan Gentleman in Venice:- "pl fu da un gerat1l-iomo NapolItano virtuosissimo spirto, donata questa comedia" - quite possibly Della Forta himself, who 1339 l1ke fornaris a Neapolitan and who spont a considerable time in Venice at this period. The theory that somaris construoted his play on a commodia dell'exte sconario by Della Porta (rather than on a full-length commedia erualta by him $)^{2}$ appears to rest on anunerepported statement by the 18th centiury scholar Franoesoo Bartoll. ${ }^{3}$ In fact, the play 18 so elmilar to Climis that no other source cowos into the quostion. Ancelloe was acted, acoordinc to the dedloatlon, in the

1 Cf. $\$ 1 g \cdot 10$.

2 For example, in M.T. Harrlok, Itallin comdy in the Ronalsaance, Urbana, 1960, pp. 216-22, where the theory 18 used to magort an argument in the text.

3 Ifotzicie lstorlohe de' oonlol 1tallent, Padua, 1781, I, 230. The question 18 fully dealt vith by Loulse G. Clubb, Glarbatt1st8 Delis Eorte Dramat1st, Princeton, 1965, pp. 250, 305-6. 
house of the Dre de Jogeuse. As a vehiole for fornaris in his rolo of Coocodrillo, 28 , we see him in the paintins, 1 it is excellant; but we should not assume that the changes from his model were directide axolueively towards the development and expansion of this role. He oays that hla model was "da gle vista, ot in qualoho parte labellita, ó florlta, per guanto con la Conica prattlos sapero Intraduoendoll 11 capitano Coocodr1110 con eloune sue rodamontate". I In fact, Coccodrillo's Iole is jy no means disproportionate (IV, il is the last soene, by no means noar the end, In whloh he appears). Olinple has been aharged acoording to Fornaris' taste ("laiblifta, o lorita") as a totality, in many details outalde the oaptain's part, doubtless to sult the troupe as a whole of whlch Fornarls was leader. Anvollos, then, is a commedie exudits - not a oommed1a dell'arte - acted by the Conrldenti in Parle. It can hardly have been the only one of 1 ts $\mathrm{kind}$. A professlonsl troupe does not derelop the technique nooessery for such a performanoe for the sake of a single play. Horeorer, the little we know of the 16 th century. Italian troupes tells us that they performed both oompdie errdite and commedle dell'artes two senres, and teohniques, related but oertalniy different. 
He may add to thle the soraps of ovidenoe that we have about the performanoe of oomedies in Prance at this time (such as d'Ambolse's plays "vouës ot receuës areo un plaloir indic1ble") and it seons qulte olear that the dramatio production of France, at least in the $1570^{\prime} \mathrm{a}$ and $180 \%$, was set within the context of aotive and freciuent stage performances.

One such stage performance is that at the aln âteau do Pougy in 1585. As 1t very probably ooncerned olther Larivey or d'Ambolse, it is worth reoallin, it hers. It was a performance of a comedy at the bapt1sm of Honr1, due de Luxembourg, on 26 January 1585 [n.s. 1586] at Fouss. The festivities inoluded a banquet, "et apros souper force lhisigue, un and Bal, une Comedie, et toute cutre sorte d'esbatements et recrestions honnestes, qul durerent I'cspace do trols jourg". I The words are frow the description of the Discours

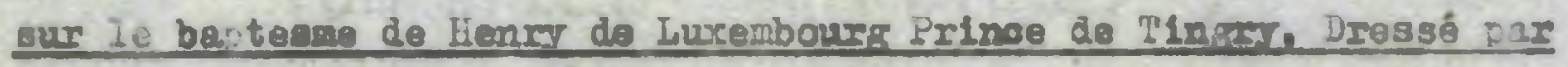
Malatre Gulliaure de Tair Doren on 1 logline de Trores that 18, by a oolleague of Larivey. The baptiam was adminiatered by the 3iahop of Iroyes. That the oomedy was one of Larivey's seems at least possibles It would be conflrmed by Larivay's dedication of his plvers diecours (from Cappelloni) to Charles, Ilenri's oousin, another member of the

1. Vignier, Histolre de 1 a malson de Lurembours, Paris, 1617 , p. 392. 
house of Luxembourg. Charles, too, was the dedicates of d'Ambolse's Les llespolitaines. The connections eeen to be top many to be fortuitous.

In 1599, fourteen yoare aftar pub11shtng Angelica, Abel 1'Angelior published a translation of it into French: Angelique Comdle, de Babrice de Fourharis Napolitain dit lo Capitaine Cooodr1110 Comique Confident. $218[810]$ en Frencole, des 1 inzues Itallonne et Espeganolle, par le slour L.C. The sap in time 18 surprising. "Le siour L.C." may woll be "Larivey Champenols", sinoe the adjeotive appears on the titlo-page on all Larivey's acknowledged work ("Plerre de Larivey Champenoio") 3 if $\mathrm{so}$, the gap in time would be parallellod by the equally surprising gap in Larivey's acknoviedzed dranatio publications, between the 1579 edition and the three subsequent plays thirty years late, in 1611. The attribution is by no moans cortaln, howere. In all Larivey's niso acknowledzed plays, the sotion ls modifled so that the plays may be "representées comes advenues on Branoe"s the place-names are changed, the savour of Frenoh collogulal speech replaces the Itallan. But Inisaliaue takes place in Vendoe, like Its orlolnal, even though its prose style is

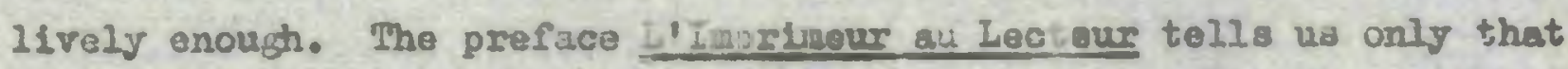
some amall ohinges have been made in the translation, There appours to be no evidence other than the inltlals "L.C." comnocting this 
translation with any speciflc troupe or I1terary circle.

When Hontal ono travolled to Italy in 1580-1, ho bought in sloronoe "un paquet d'onzo comédies". "He oan hardly have been alone in th13, and in fact many of the coples of Itallan plays now In Franch librarles have probably been in Franoe sinoe the 16th contury. Larivey, to translite ilis nine plays, must have had access to his nine orlglnals, and Turnobe and d'Anbolse, too, unless they saw their varlous modela aoted by Itallan troupes, nust have lenom ooples of thes. D'Ambolise, who oextainly travelled in Italy, ${ }^{3}$ may well have dono as Hontaisne did. But somo supploment to these imported copler was foasible, and two Parts printers a a a commorolal opaning in the ande for Itallan thingas Jerome de Marnaf and tho widow of Gulliaume Cavellat, who published in 1585 a reprint of the old faolng-page translation of Arlosto's I Supposit2

1 The printer is Abel I'injelier, the same who printed Larivey's other plass and A'Ambolso's Les Nespoliteinges but in vien of L'Anguller's considexuble other productions, this is soanty ovidenoe. - The Italien version was onoe nore reprinted, In Vonice in 1607 the dodication of this odition refers to "L'Angelica Comedia del Capltan Coocodrillo, atumpata glà in Purlgg". Th1s new edition is perhaps ourlous, since the layts close orlelnal oliming had slreody beon reprinted in Venice in 1597, after the first Haples edition of 1539 (of. Clubb, Qlambattiata Delie Forta, p. 318).

2 Journal de Voraze en Itelie, ed. H. Rat, Paris, 1955, p. 192.

3

Cf. above, p. 42, n.1. 
by Joen-P1erre de Hosmes. I It 18 somothing of a blbliographioal curlosity. Thirty-elght years had el apsed sinee the last edition of this translation, yet the typo is identioal. Ither the type had been left agt up for 38 years (which 18 unllkely) or thlo edition ropresents a number of unsold ooples of the serller edition, provided :Ith new t1tle-pages and sold off. In any case, the trenslator's name is not mantioned, and the now edition, ualike the old, is explicitly almed at the teach yourself market: "Pour I'utilits de coux qui desiront sqavolr la langre Itallenno." Hontalgne comments on the Itailan play that he knew, and his oominent, as one rould expect, is to the point. Hla tagte In some matters wae for gimpllolty - In the cennibalg' songs of love and war, for example, which he paraphrases in Des canntbales ${ }^{2}$ - and In comedy he preforred Terenoe and Plautus to what be considured the excessiva complexity of the Itallansi

Pour l'estimation do Térence, 11 m'est souvont

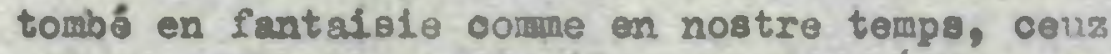
quil se meslent de falre des comedies (oome les Itallens qui y sont assoz houroux) amplolent trols ou quatre argunents do oelles de Térence ou de Iuto pour en fsire une deo lours. Ils ontassent,

I Hirst publishod by Bstiense Groulleau in 1552, of. chapter I abore.

2 Essule, *1. J. Plattard, Par1s, 1931, I, 11, 103-5. 
ex. une seule comedie, cing ou six contes de 30cosoe .... N' avant pas in lour assez de quol hous arrester, $11 \mathrm{~s}$ veulent que le conte nous amuse. 1

He is telling us here about his own taste, as so often in the Besale, and the ooment is hardly Intended to be an absolute judgoment; aftor all, Blbblens's Calandris or Bruno's Il Candelalo are not Intrinsically $10811 \mathrm{ke} 2 \mathrm{y}$ to sucoeed than Tersnoe or Plautus, and Hontal gne mat hare knom that the Calandria had in faot aucoesded in stage in Franoe in hls oin oentury. In the theatre, a stage success counts for more than any abstraot evaluative judgement. But in one polnt he seans to bo fuctually rang, as fisc as the evidence arailable to us whows Itallan samedies are not as a zule bulit up on "oing ou Blx contss de Boccace" or Indeed of any other contour. 'H.T. Herriok's Italian oomedy in the ienalsaance, which covers all the most Important plays in some detall, mentions several broed on one atory of 3000 acoilo, none baped on iaore than one. In Thanoe (as we saw in the first part of this chapter) the anly comedy besed on Boccacoio is Jean do La Falllo's Les Corrivens, and this is based on a single story, borrowing only a proper name rean shother story.

One produot of the new Italianism, in 1580, was Robert

1 Ib1d., II, 1, 115. 
Gamier's Arodamante. It may appear odd to introduce this tragicamody into a discuasion of comedy; but certain fontures of the play can best be understood in the context of apocifloelly oomic theory and practice of the time. First, the name of the ganre: a tragf-comody mey be so oulled because of certain character eloments, as lautus applied the term tracicomodis to his Amphitisyon: a play not only about gods and heroes (like a trajedy) or about ordinary citizens (Iike a comedy) but a play aixin; the two. In Brederante, the comic character element is in the couple Ayron and Beatrix. Aymon is a paladin of Charlemagne's court, and might be expected to behave aocordingly; yet he and his wife ieatrix discuse the future of their daughter Brademente as any bourgeols couple would in any out-ani-out oomedy; anxious ooncern that her marxiage shall be sooilily acceptable, conplaints that childron no lonser obey thelr paronts, and 80 an. Ihe result is a dellberately comio incon ruity. Another feature related to comedy is in the charicter of Leon. This brazgart goes through all the standara paoes of any brafiart in any Renalsaanoe oomedy, though not as violentlys ho bossts, he threatens, he is feced with the need to fight, he is deflated. Tumbe's Rodoinont, Hardy's Scanderbe3, do nothing different. This point, it ia true, should not be elasgerated, beoause although this is primarily a situstion of comedy, it is one of trafl-comedy and of non-thartrical genres as welly Gamier's 
brasgart has a model, indeed, in the orlando furioso, the main source for the play as a whole: the bractart Rocomont. ${ }^{1}$

The history of oomody at this time is not tidy. Te are floed 1th saps like the fourteen years between Ansellce and Its translation and too many facts, like the repertory of the Italian troupes, are unknown to us. We come now to two writers Whin our period isplated both geo jraphically and aesthetically from the soolety we have just discussed. The first is Pierre I. Loyer, Angerin. Better known that his plass today are his volumas on witcheraft, sizeable and pessing through thres editions in 1586, 1605 and 1608, as well as a 1605 trunslation into Lnglish. His two plays, Le mot insensé and Les iéphélooocugde, ou la nube des coouz, are quite isolated in their day. The 1869 editor of the comedy La Nophéloooculte oelled it "une auvre quil n'a pa.s, co nous semble, son pendant dans quelque langue que ce soit"s in faot, it is an adapted version of Aristophunes' Clouds, with sone elements from the B1rds; with the lost Plutus of Ronsard (or Balf; or Dorat) it is the only comedy from arlstophanos within our period. The other is Gerard de Vivre, a Ghent schoolmater. His three plays are all written "pour l'utilité de la jeunesse et us:3e des esooles francolses", and to judge from the number of

${ }^{1}$ On the brascart zenerally, of. part III below. 
editions, enjoyed some enocess in their time. All three are called "comedies", but all three are in fact hybrits. One of thom, La fidelité nuptiale, wa flrst published in $1577^{l}$ and already in part Imitates the techniques of the Italian troupes of the ' 70 ' 3 . La Vallière rightly spoaks of lazal in this plays in act II Charès, "Joune zentilhorne arec ls cappe et l'espée", sings to his lute, as a serenade to his beloved's winciow above, no fewer than fivo popular twises of the day (Toutes les nulots, Susanne un jour, Bon jour mon ocour, Douen meroire, Hon ocur se recomande à vous), but 13 interrupted by a servant emptyin a buoket of water from the riniow. In act III his valet triee to imitate him, and a whole serles of stago directions desoribe the lazzi of the scene, for exanple:

Cependant qu'il ohanter, Bortira un autre accoustre legierement eyant un masque devant la face, lequel se mectra devant la porte toút debout on un coin, là ou l'autre ira chanter, et se tlendra lis coy, conse si o'estolt une colome à soustonix les sonustrazes.

Vivre's ounoern for stage bueiness is seen, too, in speolfio styns that he uses throughout his plays the full table will be found in the chapter on staging below (II, 7). Lefidelité nuptinle and the

${ }^{1}$ Comedle de la fidelité nuptiale, Anvers, 1577. 
other two plays are as far as I know the only French plays of the century where stage direotions and siens are used in any number. The lazzi, the mask, and oertain names (Achant10, Fardaliscs) in perticular show Itallun influence.

\section{To Comatlie's isélite: 1589-1630.}

It may be imagined that Eaile Chasles, with his Darwinian theory of the evolution of literatire, found this an inprofitable period. To $\mathrm{him}$, it seamed a period of silence through which irench comedy somehow had to pass before the now comedy of the 17 th century could be resched, "Ia oombdie grandit en silence, dans le secret, pour ainsi dire; et, lorsqu'elle reparaft au XVIle slècle, on la trouve mûrie et dêj̉ forte" (La oomédie on prance au VIo siècle, p. 114). In fact, the silence is in part an absence of documente; if we ounnot "see" conedy at this time, then to continue the Darwintan metaphor, it is partly because the fosslls have been destroyed. But we are slightly better off today than Chales was. In particular, the Delerkauf-Holsboer in hor life of Alexandre Hardy (unfortunately published in a non-literary periodical), ${ }^{1}$ and Professor Gill in the introduction to his edition of Les rascieurs,

I S. Wilma Delerkauf-Kolsboer, "La vis d'Alexandre Hìrdy, Poòte du Ro1", Proceedinge of the Amerioan Philosophleal Society, 91 (1947), $373-404$.

2 cf. bibllography below. 
have demonstrated that a whole comic jenre existed at this tirs, whose plays were very yrobsbly slinilar to the one surviving exarple Les ramonoura: that is, complex, vigorous and designed as entertainment, never publishod, and standing flruly in a long thoatre tradition. Professor Gill has shom conclusively that Les remoneurs cannot be earlier than 1623 (probably 1624); ${ }^{1}$ so that if wo may. judje from this one play (and it seems that we may) then comeillo's scorn for the plays before Nellte - "Je n'arols pour cuide gu'un peu le sens comun, aveo los exemples de fou lis Herdy" ${ }^{2}$ - seems to da-ive from a prejudice ajainsti a form of drama he considered out of date, and not frow the do yenoration of the fonre 1tself. Renwisaance comedy was out of date, just as llarot, saint-Gelais and Seb1llet rere out of date and condemned by the Plélade despite any merits that may be epparent to us today. In any case, no spoclal ploading is nocossary to show that Lers ramoneura is as Iively a play, as capable of conieving stage success, as any of the 16th century comedies. 3ut how deep 13 the silence that Chasles refers to? It seoms lraprobable in hiatorical terms even if not in evolutionist onos,

1 gd. c1t., pp. $x 00 x-20 a c r$. 2 Examen to eflite, ed. Mario Rogues and Marion Llèvre, Iille and Genera, 1950, p. 135. 
that the genre of comedy ahould disappes from the scene at the end of the 16th oentury, produce one excellent play around 1624 and then take a different turn with Comeille. Let us look at the orldence. The following table roproduces everything I have found that 18 relevant to the texts of ectual comedies in Fr nce from 1586 to 1629 , ezoludin; only faroos pure and simple and references to performunce, which are nover conclusive with regard to specifio comedies ${ }^{1}$

1589 Franpois Perrins S1chem ravisseur, containing Les osooliers (possibly witten earlier).

1589 Gorard de Vivre: neir edition of pleys first published in 1577.

1594 Joan Godard: Ouvres, containing Les dosiniser.

1595 Gerard de Viveo: now edition.

1597 Fierre de L ndun d'Algellers: a comedy (text does not survives.

1597 Plerre de L rivey: now edition of plays first publisbed in 1579.

1597 Itienne Jodelles no adition of Gurses pośticuos, including i' luging.

1598 Jacques de Lavardins new edition of translation of the Celestina.

1599 vare de Fapillon (Le opitaine Lasphrise): Eurces, incluain, La nouvelle tra ionique.

1 For fuller details on any perticular itea, $80 e$ the bibllography below. 
1599 Translation of Foinuris' Ancelica (Irrst published in Paris in 1585) 1nto Frenoh as Angélique, possibly by Larivey.

1600 Plerre de Larivoys new edition.

1602 Jean de la Taille: now edition of plays first published in 1573.

1602 Gerard de Vivres new odition.

1604 Rény 3elleaus ne: edition of Gurres pocitiques, inoluding La reoomue.

1606 Frangois Perrin: new edition.

1608 Les brevachories du Capitalno Spavente, a transla.tion of the first 8 ix of 55 dielozues by the actor Francesco indreini, made by Jacques de Fontens.

1611 Plerre do Lriveys three new comedies published (but probably corjosed muoh earlier) and a nas edition of the sire earlier ones.

1612 Plorre Troterel, Les compivaux.

1616 La conédio de prorrarbas.

o. 1620 P llanurcript translation of Glordano Bruno's II Cendelajo.

1620 Pierre Iroterel, jillette (written sumaer 1619).

1624 Inon (Alexandre Mlardy?), Les ramonewre (betireen 1624 and 1626).

1624 Jean Godard: new edition.

1625 Alexandre tardy: Io jalowx (text does not survive).

1626 Odet de Iumbive: Les contens, new edition (f1rat published 1584), under the title Les desizuisez.

1629 Plerre Cornolile, Mélite (acted in the ceson 162-30). 
In a way, the chart is unfir, because it inoludes now editions nd reprints; but even reprints show the interest of an age in what is beins reprinted. Booksellers then as now were in the trade to stay in business. There are one or two other scraps of evidence: in the 1626 edition of Turnèbe's Les contene (no: entitled Les desculeez), the aditor Charlas Haupas writes that many people have admired the play so much that they have been maldng coples of $1 t$ by hand. ${ }^{1}$ and besides Le folowx, Mlexandre Burdy almost certainly wrote other comedies that do not survive. ${ }^{2}$ In ganeral, we have a picture of no age from which almost nothins survives to us but where activity is apparent. Fe sec Plerre de Lakdun d'M1sallers writing his oumedy in 1597, Les remegours in 1624, Nerdy's le Jaloux in 1625, Rierre Troterel parodyin: the gonre (as we shall see) in 1612 and 1619 (and you do not parrody a genre if your audience ls not faillar with the real thing). It looks very mach as though essential texts are missing, poselbly a large number of them. Why? The inswer may well lie in the finanoial and administrative arr ngements of the theatre and of the eiuivalent of copyright at the tum of the century. Paradoxicelly,
1 cf. Odet de Tumèbe, Las contens, ed. Spector, p. xiv.
${ }^{2}$ Cf. Les ramonours, ed. Gili, pp. Irili-lxil. 
It seoms that when the theatre beome eatablished enough in Brunce for regular troupes to appear, for the theatre to beoome a profossion, publication limmediately and as a direot resuit became less easy. Imo Delerkaf-Holsboor has show how Hardy was gpoolfically le fally debarred, in his contracts with the troupes, from publishins his plays, while the troupos themse?ves (who mould hold the manuscript) would have little interest in publishing a glay after its first staje sucoess was past. ha for the manusoript coples, these are notorlously ephemerel and may quite essily all have disappeared, like the composing copies, supgostd to have existed, of medieval and Penals sance musio.

Howerer that may bs, let us look at the comediea that do survive. Frangole Perrin and Jean Godard, 1solated from the oirole of d'Ambolse and his friends, need not conoern us lons here. Structural eloments in their plays will bo dealt with in grenter detall below. Brlefly, Ferrin's ourlous Les escoliers is the work of a provinolal churahman, with wide interests like his fellowwithout

shurchman Larivey, but Itrivey's zest. Besides Les escoliari, he wrote a collootion of sonnets; a tragedy jiohom ravisseur; a trajedy Jephts which miv have been a translation from Buchanan but is now lost, ${ }^{1}$ and a history of his orm city of Autun, "enciene

1 Ono of the poems printed in S10hem ravisseur, by J.3. Derdault, Is hosded "Sur la tragedie de Jephte tradultte par híonsleur Perrin". 
oapitale des Gaules", never published, and also now lost. The volum containing his plays ${ }^{2}$ is an inelegant place of printins by Guillaums Chadilere, the codications, 1 iminary verse and titlepazes haphazardly arreasod. Only ono copy of the first, 1589, edition, survives today, nnd evon that was not known to the isth century oditor of Les oscolleis, Paul Lacrolx, who worked from a muscript copy mude by Soleinne (now in the Bibliothèque liationale). ${ }^{2}$ Les escollers 1tself is a 311 ht ploce of writing, an elaborated, sene hat humourless farce with elomento of the Itallanate conventIons of Perrin's prodooestore. It may date from earlier than 1589 , as ferrin savs that he sourched it out from "un Brand fatras de vieux paplerg". There seeme to be no internal eridence of date.

Les dessuisez, publishod in 1594 in Godard's CLuvres, ${ }^{3}$ Ingy also date from earlier than its publicatlon: there seoms to be no internal evidenoe which would dete it aore precisely. It ia a procuct of tho ildis Godard, though a Parisian by blrth, lived in

1 Slohem ravissour, tryedie cxtrajto du Genese trento quatilewe Chapitre. Par Prangcis Jerrin Autunois. Daris, voillaume Cheldiere, 1589.

2 Cf. Bibliography.

3 Les ceurres de Joen Godarde Parisien. Tro vols., Iyon, Plerre Landry, 1594. Lai doscuisez, vol. 2, ps. 91-208. 
the South, published hle book in Lyon, dedioated 1 t to a Lyon worthy, and set his comedy in Toulouse. ${ }^{1}$ He adspts from Ariosto's I Supposit1, the third French miter to do so in the 16th century, and in some ways he deserves more credit for his adaptation thon he has sonetines recelved. hocording to clorenescu, the plny is dul1. But, for instanoe, prouventard the brasjart cavtain and Hauclole the brasgert valet have scenes whlch are good theatro, as we shall see, and which aro Codarc's creatlon, not Arlosto's.

The interest in Itclinate ecmody that we disoussed in the precendin chapter - a tradition from which codard ouriously seems to stand aside In mony vays, despite his sdoptation from Ariosto - continues into the 17 th century with three neg comodies by Larivey and a number of translations, dialozues, pictures, and other eccessory works. The Larivey comedies, published in $1611,{ }^{2}$ are in some ways a curious surviv: 1 frem the 16 th century, rather than a living product of the early years of the 17 th. Lexivey says that the plays are ones which he has found, dusty after meny years, In his study, he decicstos them to Frangols d'Ambolse, to whom he

1 Not "Valenoe", as A. Cimrnesou states (L'Arloste en France, vol. 1, Paris, 1939, p. 302.

2 Trois comedies des $\mathbf{s i x}$ dernieres de Pierre de Larivey Champenuis. A l'initation des anciens [sic] Grecs Latins et
Fodemes Italiens. A scavoir: La Constance. Se 'idelle. Fit les Iromoeries. Troyes, Plérre Chevillot, 1.11. 
had also declicated the 1579 collection; and as far as can be judged, the style gives no evidenoe of a date of composition later than that earllar collection. They are not, however, Incongruous In 1611; ne: editions of the 1579 collection had continuously appeared since then and presumably found a market: in 1597, 1600, and ajain to sacompany the new pl nys in 1611. The now ones are as clos a sdaptations from the Italien as the old had boen.

A continuing interest in Itallanate oomedy is shown, toc, by the three translations whlch we discussed in the precodin chapters Anéliau, in 7599, from poinuris' Anvellca, possibly mede by Larivey, and two translations from Giordano Bruno's II Candelaio, one printed in 1633, one manuscript und possibly earlier. Les bravacheries du Caoltalne Sparente ${ }^{1}$ Jives us another

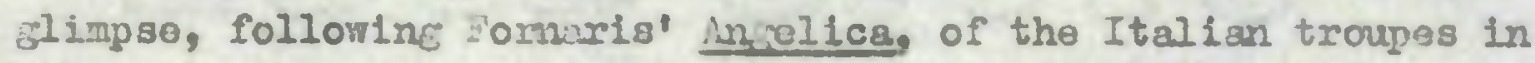
Porls. The author of this is anotier stase eaptain, francesco Ardreini of the Celosi, whose stwe lilme was "Il Capitano Spavonto" anc who tells us in his book that it is "una recoolta di tutti le Hiperboll, on'lo soleva dire nella Parte del Capitano Sparento, recitando nelle

1 Le branure del cepltano spavento. Divise in nolt1 ra ionareant1

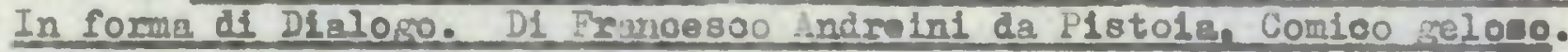
Les bravacherios du ospitalno Spaventer divisees on plusiours discours en forme de Dlalosua. De Frangels Andruini de Plstole. Comadien de Is

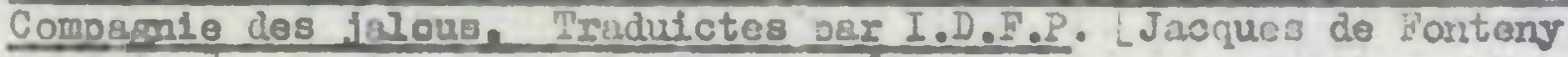
Faxisien]. Paris, David le Clero, 1608. 
Publiche, e nelle Prlvate Comedie" - just as the part of Cocoodr1llo in Angellog probebly tells us something about Bomaris' stace delivery. The original of the Bravacheries was published in Venice in 1607, ${ }^{1}$ a lon; serles of 55 dialogues, of 406 pagres. The translation, by Jaoques de Fonteny, fives us only the first 81x dialogues, but the shortentns is probably rather a good thing. The $31 x$ include things that a Frenoh audlence would certainly lonow: the fanous 110s glorlogus oplning about polishing the Captain's arnour, which is in Les ramoneurg:

Va de ce pas vers Vulcan mon Armurier, et luy di de ma part qu'il pace mes armes, plus claires que n'ost lo soleil quand 11 eat lo plus clair, afin que la splendour d'1celles oste la veüe aux regardano?

the proverblal hunger of the valet:

Ifion malstre rosouvenez rous que I' houre de disner est quasi passea 3 :

or the reference to the old Jrench war-horse Bayard (whom Adem de

1 Ie bxarure del canitano Spaventol divlae in melt1 re lonmont1 In oxma di J1810 on di Prancesco ndrolni da Plstola Comico Geloso. Vonlce, Glacomo intonio Somasco, 1607.

2

Bravapheries, f. 2.

3

Ibid., f. 21 . 
1a Hallo had already put out to Graze): ${ }^{1}$

[Order my trompette (trumpeter) to ribe early on the day of the perade] "et que galoppent son chevel Bayaxd, Il s'en aille par le cltë sonnant bouttesello, boutte-selle, tous \& cheral, tous à cheral, tous à ohevel 2

or to the old olerious-miles disputes

Hon malotre ohangez d'advis, no mettez à rostre table des docteurs, et des Capltaines, parce que par entre eux ils be rompront la teste, seulement par la preference cui se recherohe entre les gend' armes, et les lettrez.3

Jacques de Fonteny dedlosted the book to a real-life osptein,

Charles d'Anjones, "Capiteine dos cent Gentils-homes de la resison du Roy, et Colonnel ganeral de I'infanterio Italionne". Another real-life oaptain, "Le Capitaine Lasphrise", otherwise liare de Papillon, produced a by-product of our comle tradition in 1599 (thouch grobably written by 1597): La nourel1e

1 "Or eat Bayard en la pâture", Rondewur, ed. J. Cha1lley, Faris, 1942, no. 8; of. forthconing edition, The lrric worke Or dan

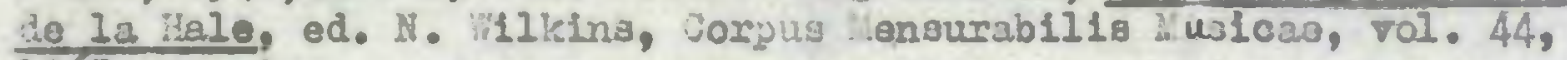
1967, no. 9.

2

3rsvacherios, 1.9.

3 Ib1d., f. 27. 
trastcomique. I It is a rork without parallel, as far as I lnow, In its time - indeed, possibly in any time. Papllion vas a man who in an ago when the gab of the stage brabjart was knom to every eduoted person, und to a good many who were not, could write such a seb about himselfs

Ure je n'ay redouté ni l'onde glaciale, Ni celle dont l'ardeur d'une sutre n'est esgrale... ... etc. ...e etc. ...

Vous m'en estss tcsioins, rencontre de Dormant, Ou je fus vo twant, an pourpoint, pesle-mesle; Le Vermay, Vymors, Foosé de La Rochelle, Vous, monde d'escarrouche, assauts de Lusicnan, Danfrons, Salnct-Lo, 3rouase et Fontenay, Maran, Salnote, Masle, La Weure et villes dauphinoises, Ls Gasoosme et Thetis ...?

or this Cartel:

Cartel snvoyé aur ennemis à Boutteville par des Capitaines mes compronons et moy. Par le Capitalne Lasphrise.

Vous autres qui vivez ...

Hous somes six soldata au Servioe du Roy Qui vous irons trouver vous donnant notre foy, ortsinal: nous donnant votre foy]

Jour vous combattre hacdis areo espée et cappe. $31 x$ do vous solent donc prots, pour scquerir honneur.

1

Les premleres cuvres poetioues du Capltaine Lasphrise: Two vols., Parie, Jean Gesselin, 1599 (priviloge 31 Jan. 1597). La nouvelle trggloomique, vol. $2, \mathrm{pp} .635-657$, reprinted in Neien thistze francais (of. biblioiraphy), vol. VII, pp. 463-491.

2 nolen thêâtro frengais, VIII, p. 465. 
"C'est toujoure au denjor que reluiait la valour "Slais il est bien heureux quil de nos mains eohappe."

The bresgart in hls play, ho:rever, Furcifer, is hardly one at all. People call him a "vaill nt gendarme", an "asseurs brifand si plein d'artiflce", but he had no gab, nons of the usual attributes. He escapes retribution at tha end, however, like most fienaissance brajurts. - The play itself his an extreordinary, quite possibly a unfque, structure. Eapilion says at the beginning

Je n'ersily en cette ourre loy

la fagon de l'ardeur antious

and indeed hedoes not. Sut nor does ho simply imltate the furces. ie are glven a lament on a'friend's death, with idess on vengeunce typical of the most Seneoan of trajodies ("Par vengenoe on connolst le ocurd'amour parfait"), the consultation of a mafician in a remote valley; an action which noves from a house outside puris, to the valley, to the cates of Paris, to an inn in Paris, to a prisons and althouch there is no prologue, on four occasions characters (different ones) turn and speak to the eudienoe, commenting on the actions

Hoรpes:

S1 jamais on a veu una ame perturbbe,

Il fallait volr Griffon ...

1 ibllothèque Nationale, ins Fr. 24450, f. 84 . 
Griffon, lw, n'est plus luy, par I'estrange spectacle: Il ne dict ni ne falct, car oe triate miracle Clolsoit la bouche $a$ tous quil sont sortis de là; Puls enfin, oouspirant, au traistre ainsi parla.1

There ls no act-division - inlead, no divialon at all - and the play is shorter than most 5-act plays and lonser than most faroes. Papillon seerns to use his title es a blanket term to cover as varied a collection of dranatic whims as the fiensissane ever produced. - Ono winoin Idea of Paplllon's is to oall the watch by the name of Rabelaig' Chicanous, that is, people who sre paid to recelve blows and who never deal them.

With the two "oomedies" of Plerre Troterel, Sleur d'Aves, Leg corrivean of 1612 and Gillette of 1620, we oome to a different kind of theatre. By their subjeot-matter, they are faroes; they are certainly inficent and make little demand on the intellect. But they are structurelly rather more than farces. H.C. Lancaster sew morit enough in then to rejret their imorality. ${ }^{2}$ Anl if we are interested in the cinds of thectrical convention ourrent in Frrace In the opening years of the 17 th century, the two plays take on a new interest. They appear to take for granted the conventions of

${ }^{1}$ incien thsatro frundels, VI, pp. 486-7.

2

H.C. Lanoaster, French Dramatic ilterature in the Seventeenth Century, part I, vol. I, Baltimore, 1929, p. 144. 
camedy to such an extent that they become parodies of the genre. A knowledse of those conventions is assumed in the audience (or reader). Lea corrivaux, for exarple, has an ddvertiecemant au Lecteur nocking that part of conlc theory whioh claims a morel sunation for coinedy:

Leoteur sçsches qus je $n^{\prime}$ ny pas composé cante folastre comedie, pour t'apprendre a suivre le vicer our il $\mathrm{n}^{\prime} \mathrm{y}$ a rien au monce que j'abhorre tant. Dt te fure do bonne ame cue je hay plus que la peste ceur qui lo suivent. Le subjeot dono, pour lequel jo l'ay composée, est à fin qu'en y royant sa noirocur ai bien depeinte, tu t'animes a suivse la vertu. Ainsi les anciens Ronalns faisoyent ivcer lour serviteure et esclaves, dovent leurs orínts, à fin qu'on contemplant leurs viluines actions, 118 apprinssent is fuir la brutallo svronperie, et les autres vices qui la ourvent.

Troterel's tongue-in-cheek clafin for the uplifting nature of his play oun best be savoured only if jou know the pleoe of theory bolind it.

A prologue, spoken by a brajgart, begine the play. Sut this standard piece of comic structure is interrupted by someone (Le Gaohe) behlnd the curtain of the stage: this is surely almed at an audience famillar with the usual uninterrupted prologue. Ind agaim, one the plas starts, we find that there is not just ane brajsart, but two or even three. And so on. Whe ther we consider these thinge as viriations on the conventions, as in the oarlier comodios, or as 
parodies makin fun of the: it seoms that farllarity with those conventions can still, in 1612 and 1620 , be sssumed.

With Los ramonours, wa are back in the main strean of

comedy, with a play (as we saw above) probably typical of a number that no lonjer survive. horoas Iroterel had parodied the conventions and had been heavily influenced by the farces, this play merely assumes the conventions and is as different from the farces as any comedy of the 1570 's or $1580^{\prime} \mathrm{g}$. Profossor Gill had discussed it in some detall in his odition, and we shall exanine a number of festures later; but perhaps one point should be wade here. Les rmonours dates from at earllest the 1623-4 season. Comellle's sesle datois from the 1629-30 season, at most six yoars later. Comeille clalmed thet his play wa written in a kind of dramiatic wildernoss; but Los r monoure shows that this is sirply untrue. It is a lively play (and as frofessor Gill hits shom probably vritten for the profescionil theatre of the time) and ane whose features are olearly treditional, the characters, the pose form porformance by the traditional faree-eotors at the Hotel do Bourgogne, the liminorilty, the struoture of its plot. It is ajainst this tradition, surely, that the udiences of 1629-30 sas plerre Comoille's new comedy Helite.

There can be no doubt that yellite did in fact inaucurate 3. new type of comedy in irances the fact 18, though, that the nemess 
does not lie where Cornoille olaimed that it did, in his Dxmen of the plays

On n'avolt jamale veu jusques-là que la Comedie fist rirs sans Personnases ridioules comme les valets boufons, les Parasites, les Capitans, les Dooteurs, etc. Celle-oy faisolt son offet par l'humour enjolíe de d'une condition au dessus de ceux qu'on volt dans 100 Comedies de Plaute et de Terence, quil n'estoiont que des larohands.I

eilite's aim is not to malie us laugh; nor does it avold conventional charactere, since the nurse is uttorly traditional, Phllandre has more than a touch of the bragsart soldier about hila, and Comeille admit 3 that Eraste's madnoss is a traditional theatrios device (thoun not of comedy), nor is there any dratiatio ginificance in any gocial diffarcnoes that there may be.

The novelty lies in a naw ethlo of love. Before Cornellle, the love-affalrs thet larmed the core of the plot (then the plays were not frankly innord like L' lu rane and la trasorière especially) were so bound up plth Renaissunce soclal structure that the parents of the joun peoplo thomselves pluyed an important part In the plays. Here, that sociel structure has been relogated to the backround, so that Mellte's mother does not appear, though her

1 Plerre Corneille, Mélite, ed. linario Roques ank Marion Lièvre. Lille and Geneva, $1550, \mathrm{D} .136$. 
approval is st1ll necessary for a marriage, and the action ouncarns only the youn people and is conducted acoording to the preoloux love-ethic familiax in the salons of IRadame de Ramboulllet and her successors. Consequently, there can be no peril of the old finlliar Ifind; no relation or friend of the family as a deus ex machina. The emphasis has chanzed, from declin with external perils to exanining the affeotions of the characters. Hence the unifled, even claustrophobic plot, honoo tho dienteled alexandrines, hence too the emphasis on indirlduality in the different kinds of affections. Some characteristics survive from earlier, such as the nurse and the brasfart parts of PhIlandre's characters the convention of staglng with decor simutant; the ep1lo sue spoken by the nurse. But they are externals, and it is clear that a new tyine of comedy has begun - neir, but not in the weys that Corneille claimed. 


\section{TH: STAGE}

The stages that were used for French Renalssance colledies are very mah a matter for deduction from indireot evidence. The loonosraphloal sources that survive are only partly relevant, beouuse they refer only to other, though related, jenress to Terence's plajs as lllustrated In Ronalssance editlons, to farces, and to Italian comedes. Somethins oan be zained from medieval 1llustrations, even though they are before our period, and from the M\&molre de liahelot, even though it is after 1t. The Iise of the professional troupes provides information in arohives mainly from the and of the 16th centuxy onwards. And flnally the plays themselves, if we look at them in detail, oonsistently lmply certain kinds of staging. All this evidence taken together, soattered though It 18, does oventually provide a coherent pioture of the comlo atage within our period.

\section{Illuatrated editlons of Terenco.}

The woodouts in Renalsganoe editions of Terenoe have recently been exhsuotively discussed by T. . Lawrenson and Helen puriels. I Their work shows above all that as the woodcut in

IT.S. Lamronson and Helen Purkis, 'Les éditlons 1llustréos de Torence dans l'Histoire du thếtro', Lo Llou thếtral ì la Renalseanoe, od. J. Jacquot, Paris, 1964, pp. 1-23 and plates I-VIII. 4. f.g. 3-5. 
Renaissance printed books is an art-form of 1 ts own, these 11lustrations too must be regarded in the first place as examples of that art-form. Renalssance woodouts were decorations, Intocrated into the dealgn of the printed paye, often copied or combined or used assin as the output of printed books increased in the 1ate 15th and early 16th oenturies. So these 1llustrations of Terenoe's plays were copled and adapted from edition to edition, the 1545 Venloe edition for exanple st1ll using variants of woodouts found In the 1493 Lyons one. They are decorations, examples of an art form and not necessarily representative of actual stage conditions of the Renalsounce.

Professor Lawrenson and lsB Purkis diatingulah three kinds of tage shown in these lllustrations to the early editionss an ontire theatrum shown in a certain number of frontispleoes a straight row of domis and a scoup of domi projectine forward into the centre of the ploture. All three represent something theatrically simples a platform with, at the baok, up to flve compartments. There is no elaboration of what the compartment 3 are masnt to be there are no windows, no balconles, or the 11ke, nothin; to indicate a difierence between one kind of bullding and another.

Upon this pattern is imposed, towarde the middle of the 16th century, the Serlian design of a noutral epaoe surrounded by stage elements on threo sides: a city street, with zepresentations 
of houses and ofty bulldings. Such a design first appears in the Terentian 1Ilustrations in the 1545 Venice edition, while woodouts showlas the older pattern still continue to sppear, and by 1614 we have the flrat edition of Terence using only the Serllan type of design. I Serl10's work was flrst published in France in 15451 we shall return to it later.

for far, then, are these woodouts sources of Informition about 16 th oentury theatre dealon, in partioular for comedy? It is apparent that a too literal interpretation of theris 1 dingerous. But there are two ways at least in which they are relevant to the 16th century staje, and in particular to comedy.

Firet, an artiat, eren if interested primarily in the desion of a printed book, does not produce a ploture from nothing. We will be quite ju tifled in looking to the theatre for same inspiration. Professor Lawrenson elsewhere rightly looks to the medieval ustery play for some of the inspirations

Firstly, the period of Torentian 1llustration 1s that of the mystery play. Secondly, the conoept of house in the comedies of Terenoe and the manstan would easily be allied in the mind of the 1llustrator. Thirdly, whenever the houses in the Terence 1llustrations jut forward they are virtually identioal with

1 The woodcuts in this 1614 edition by Jean de Tournes, are ourlous in that they had already existed a half-century earller, sinoe 1556. It 1s poseible that they were even then intended for an edition of Terenoe, but this is unproven. CF. Larronson and Purkis, op. oit., p. 17, n. 32 . 
the baldaquin type of mgstery compartment. Fourthly, the labelled houses in the 1llustrations resemble the sariteanx of the aystery, and fifthly Lrowe of ingstery mans lons can rese ble an arcade such es those in the ferentien 1llustrations].

The complex medieval msstexy and pession play sets, though, used moh more than mere curtains for their doni, sone, such as Eell and the Sea of Galllee in the Valenciennes set, are very oomplex. why, then, were these Terentian woodouts so simplifled? Partly, certainly, as a kind of abstract systematisation of the action of the play (Badius wrote, far Trecheel's 164 A edition, "Erfeclmus ut etiam Illiterati ex lmofnibus quas oullibet scense prasposuimas, legere atque acclpere possint comica arsumenta")/ but partly also, I think. beoalise the thratre of the time which may have influenoed then Included not only myatery and passion plays but also farces and sott10e, whose atages were much simpler." The late 15th century, when the early lllustrated editions of Terence were produced, was, after all, the golden of of the furce. Whether as 180lated pleces or as parts of a raore extended play, farces were at the time of the

1 T. . Lawrensan, The Freroh stake in the 17 th century. Manchester, 1957. P. 52.

2 The distinotion between faroe and sottle need not detiln us here, where we are discussing only the question of stagtar. Cr. Ian Maxwoll, Franch farce and John Heywood, Lelbourno, 1946, pp. $18-20$. 
Trechsel odition the only flourlshing comie theatrical form in Frances and they were, of course, much simpler than mystery and passion plays and, as we shall see, performed on more primitive stares. It may well be that the simpliolty of the farce stage had some Influense on the illustrations to the new editions of classical comedy.

The early editions, and Truchel's in partiouler, were humanist productlons with a podagoglcal alm. The starges they show, 38 we saw, are in the first plsoe systematisations of Terenoe's comedes secondly (and loosely) they derive from contemporary stazes, and thirdly they comespond (In an even looser fashion) to humanist ideas of the olissicel stage (1deas about five entrances, oto.). The parallel with the nature of tho flrst native Fronch comedies is remarkable: Jodelle and his Lmediato suocessors are also humenists, with serious alms even if not pedagoguas; they Imitate above all the contenporary stage, that 1s the faroes; and only very loosely imitate the olassical models for which they enthuse. In the stage practice of the $1550^{\circ} \mathrm{g}$, as with the illustrated editions of Terenoe sixty years earllex, the attraction of the faroes does seem to have been stronger than the attraction of classical models.

Secondly, whatever stages may have actual ly been used for fensiseance comedies, sny oultivated member of the audience of suoh 
comedies oannot but havo hal these woodouts in aind. I'erence's plays, as wa have seen, rere part of every gentlemen's oducaticn, und they were studied doubtless in these lllustrated editions, so that plass in a olassical ganre, such as the Plelado's comedies, would Ineyitably cell these woodauts to aind. They would, thex take their place within the olose relationshlp of suthor and audience, in the small humantat and Court clrcles of the $2550^{\prime} \mathrm{s}$.

\section{Bances.}

It is remarkable how larje a nulaber of encrarings, woodcuts and paintings are inspired by Renalssance furces In Fince and the Low Countriess quite a large proportion of the whole iconographical ovidence for Fremoh Renalssanoe staje design. Thls proportion, thouzh, probsbly does not correspon to theatrical real1ty. Cnoe asain, we are doaling not with any kind of deliberate historlcal record of the theatre, but with the fine arts? a fashion of painting probsbly socounts for the large number of those pletures, Just as at other times frohions for st1ll-11 fos or lanuscapes produced large nuabers of patnitings of those kinds. The sisplicity and vigour of the faros stages azs well have sppealed and so begun this partioular fashlon. Other thestrical jenres attreted less attention from artists, even though re know from other sources that In torns of the actual thestre they ware as important as farces: 
religlous plavs st1ll, but particularly formal tragedy and comedy. But whereas the Terentian woodcuts gave us little reliable evidence about actual atasges, these plotures of farces are prabably rather nearer reality. The plctures all show \& simple, erem primitive platform stage. The ting palnting in the Cambral oft of part-books, ${ }^{2}$ the 'Playerwater' detall, ${ }^{3}$ and the plotures of Tabarin, 4 all show trostles supporting the stase. Such stajes were, the;, portables and indeed, it wes essential to the early professional troupes, before their establishment in Paris, that they and their equipment should be mobllo. The earliest known travellin; profees1omal troupe, at Rouen in 1556, speoifloally performed farces ca part

1 Suar a stage is probably the desoendant of a single elenant of the multiple decor of olaborate religlous productions. In Fouquet' $\beta$ Nartrce de Solnte Apolline, the maisong are al roady independont, with thoir orm atage and roof, and very like the farce stajes of these later plotures. This orl gin is the more likely since farces wore in fact soted as part of such religious productions. I am incebted for this susgestion to the unpublished thesis of A. Iindley, The Development and diffusion of farae in Brance towards the end of the Iddo tres (Univeraity of Hull, 1965), p. 349 .

2 Cumbrai, B1bliothèque muniolpale, us 126, vol. II, f. 53. Reproduced in L. Nouseinao, Le théátre, Paris, 1957, p. $123.4 . \mathrm{fg} .6$.

3 Amsterdam, Rijkamuseum. Detail of a painting attributod to Pleter Balten. Reproduced 1bid., p. 197 . If fig. 7.

4 Two eneravings, reproduced respeotively in houssinsc, op. olt., p. 161, and in (Cambridge, Mass., 1960, pl. 10. 
of Ito repertoty. ${ }^{1}$ Tho equipment is rudimentary, senerally Inoluding a ourtain at the back. In the first two oases above, thore is an area behind ths curtain from which actors may appear. A table and ohair, and musioal instruments in the osee of Tablain, are all the propertios used, though others are referred to in the texts of faroes. The beauty of the cambral painting is that it oatches perfectly the atmosphere of one side of this kind of performances sadness and desolstion, dusk approsohing, vexy few spectators. The other plotures have mostly exphssised the other sides lively but cheap and brash fair found entertalnmont, pald for by colleotion and not by admiksion, often linked with comerce, as in the 'Orvietan' print. ${ }^{2}$ Tho sadnoss is famillar to us todsy from Chaplin and from a whole tradition of muslo-hall, the brashness wo still soe set agalnat that sadrees, as In Las Dnfants du paradis. Can these farce piotures toll us anthing about tho stage for honalssunos oomedies? Ajain, I think, primerily in the context of author radienoe relationohip. faroes ware the only thriving comio

1 cr. Wlley, op. olt., pp. 37-9.

2 Reproduced, for exrmple, In 411 ardyoe 1110011 , Hasicg, Hilmos and miracles [1931], Ifew York, 1963, p. 225. (A Group of fieures on the left of the stage are not spectators, as suggested by Jean Jacquot,

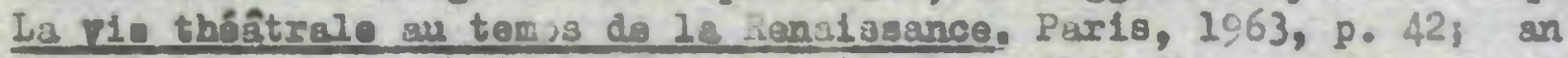
inscription above their hosds makes it olear that they are a group of sctors, 'extras'.) (f.fig. 8 . 
fora in the Prenoh theatre of the mld-26th century, and thelr stazes must therefore have bean known to the audiences of the Pleidade comecies, plays which are themselves, as we have seen, so sinilar to the faroes. Sebillet and Du Bellay oertainiy lonow then and referred to them, the one to approve and the other to conderm. Jodell''s L'lugene, the flrst arench henalasanco comody, really noeds no more in the way of atsige dasion than does a typical faroe. Indeod, in a sense, it sems to require 1080: for the text of the farces themselves often seems to exggest acre compler. stajes than the giotures of farces over show. Ne may take as an example one from the Rocuell I'sepperel, the Faroe a trols personnaress Le savetier. 10 se cont ot 1 a laitière, " whloh the oditors date in the $1480^{\prime} \mathrm{g}$ or $1490^{\prime} \mathrm{s}$ s this play seems to demend two diutinct 'oompartments' and a neut al 'street' space, for example at 11.14 and 81 'estes vous leans', 1. 88 'en ma maioon', and 1.195 'hors de mon repaire'. The Faroe du porteur d'eau, probably dating frum the $153018,{ }^{2}$ seems to need more st1118 each of the three scoondery

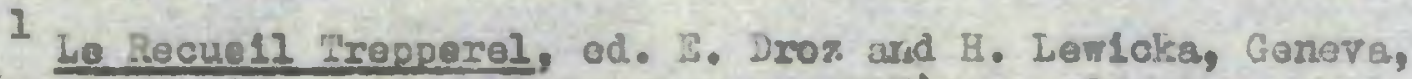
1961 (Iravewx d'turnanisma of Ronal seance XCV), pp. 25-40.

2 Text in is. joumier, Le thâêtro prange is arant le

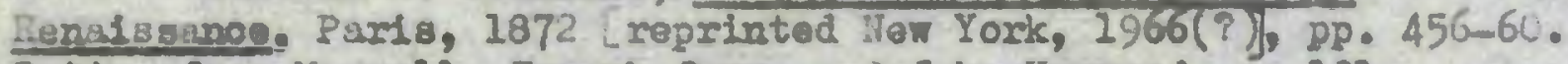
Datin from haxwell, Brench farce and John Herrood, p. 131. 
charsoters (the ontramettour, the amoureuse and her mother) seems to have hls or her orn compartment, and all four seeil to more every for lines from compartment to compartment. At one point they eren go to churah to bo marxleds "Ils s'en vont à l'ogllse et eotant roverus lo yorteur d'ecu conmenoe à dire ..." Improvistion 18 easier, though, at such high apeeds and since the progreas of time is troated with the scantest respect of any pley I know ("Car O'est demsin, vous lo sgavaz/ qu'll nous faut aller à l'egliso./ Soyons, d'uns fagon exquizo,/ Tous deux fort bien sccommodez/ Vollà le dimanche rom..$n^{1}$ ), there is 2 ittle rouson to suppose that any very great respeot for stuging is nocessary. ${ }^{2}$ So also, surely, for Le suvatier, le sercent ot la laftlere, and for lionulosanco farces In generel; but it would not nocessarily be right to oonolude that It is also so for the more lasmed genre of Renaiseanoe comedy. Wo shail roturn to this point.

Another plotoriai genra that awaits proper coment is the woodcut 1llustrations to early sditions of farces. So few of these

\section{P. 459.}

2 A. Hindley, The Derelopment and difrusion of faxpe, pp. 328-44, comes to the sare conclusion on tho same scounds: that the te:ts of the farces seem to susceat oomplex sets, but that since the plctorial orlisnoe forblde our takin theis Iiteraily, wo are foroed to the conclusion of improvisation on simple stajes. 
have been published that it is diffloult to draw solid oonolusions; but from the title pares of the reouell Irepperel, ${ }^{1}$ from the 11lustrations to Patholin and others in the British luseum, it does seen that in general the plotures are dram a thoush the scenes were happening in $11 \mathrm{fe}$ and not in a theatre. The woodout in te savatier, lo sernent ot la laitlexe, for example, shows grass and a flower, and a horse in the baoksfound, and so tells us little sbout the stege. ${ }^{2}$ Like the Terentian 1llustrstions, these woodouts vere doubtless primarily intended as part of the design of a printed page, and scarcely at all as lliustrations of stages.

\section{Itallan oomedies.}

With the arriral of the Italian troupes in Iranoe from 1571, a new kind of thestrioul illustration appears engroving;, woodouts and paintings of the Itulian comedy. This plotorles cenre is to some extent less clear-cut than elther the Terentlen roodcuts or the farce plotures; but boing (at this early dete at least) 1088 formulated as an artistio gure than el ther of them, wo may perhaps rely on these plctures rather more to find out about actual stage sets. They are of two kinds, flret the engravings and woodouts

1

ad. olt.

2 liecull Irepoerel, ed. oit., p. 29. 
found in the Recuell Fossard, the Compositlans de Rhettorlove (Lyons, 1601) and in 1solated souroes of a similar kind, and second, apparently of a different nature, paintings of groups of aotors on atage. The first clagrly represents the oommadia dell'arte in Frances an as we nove into the 17 th century, the Intersration of Itallan connadsa dell' axte actors and Irench farce actors, begun elrisdy in the $1570^{\prime} \mathrm{s}$ with Aman Sarat and his troupe, becomes more apperrent in them.

The second kind is less farcical, nore dignifled. But the division is not sharps some palntings of this socond kind are certalnly derived from Foesarel engravines, and it is even possible that all of them are. ${ }^{1}$ Howevar, it may 2180 bo that aom at least of these peintings represent not the commodis dell'arte, but performances of a ootmodia erudita or of some other genre - not neoessarily other actors, but the same actors in different roles. I have not scen this sugrestion mele, but it seens probables the flrst Italian troupes in France, we know, performed in both styles of acting. In that case, for instance, the glotures often referred to as the earliest represent it lons of the oormedia dell'arte - one

1 natiole; 800 bolow.

As, Indeed, Charles sterling has susgested in his 
In private posseseion in Parie, ${ }^{2}$ the other in the Wusde Camavelet, Parls ${ }^{2}$ - could equally well be plctures of lewmed comedy. The very essence of eormedis dell'arte improvisution has meant that we know very little of 1ts procise characterlaticas but from the ease wth which Pormarls, for example, could insert his character of coccodrillo into a leamed comedy, the two kinds of acting do not seem to have been so very far distant from each other, and were certalniy prsotioed by the same actors.

inost of the gurviving patntings have been olosely discussed in an axticle by Charles Storling, ${ }^{3}$ whose conolusion is that as a group thay are derived from ongrevings such as those in the Reouell Possard. This is demonstrable for paintinge in the New York Metropolitan línocum at Rennes and at Bézters, which all show groups of aotors in Itallan ocmedy-scenes. The paintings have stylistlo

1 Reprocuced In W1coll, Mekg, mimeo and miracles, 118.224 a sxoup of Beren eotors, includins an old man with cuckold's horm, whout stave setting.

2 Reproulucod in $110 y$, Tho early publlo theater, flg. I; a spoup of five actors, with two othor fljures in the wing, with a yian curtain as brckizouna.

3' arly paintings of the Colmedla dell'arte in France', Bullatin of the Lotropolitan Musoum of Art, New York, 1953. pp. $11-32$. 
affinities and generaly show lewish characteristios, so that once again wo have to some extent a defined artistle gonre. The engrsvines are not dlocussed by Sterling, and would need a separate study, as far as I know not yet written.

One paintine in the linsée Municlyal at Bayoux particularly concerns us here. Dated by sterlins from the costumes at $1570-4$, 1t shows a group of eleven actors in the foreground, one of whom wears the costume of Pantalone. ${ }^{1}$ Behind them is a secand group of nine people diffioult to ldent1fy: possibly further actors, or, as Sterlin; sug,esta, a courtly audionce. No enstaring like it io known, omly a water-oolour in the lennin collection in the Bibliothòque Nationale, Cabinet des istampes, ${ }^{2}$ showing only the front group and possibly deriving from an identioal source. The most interesting feature is the back oround a faosde wth an aroh In the centre ohowlng a view in perspectivo - preoleely as in the Teatro 011mploo stage at V1oenza. It 18 the only ourviving Renalssanoe ploture in prance of such a stege set in the streight thestre. ${ }^{3}$

The other paintings, and the Foanase prints and the

1 Reproduoed in Lawrenson, The Brench atare, flg. 29.

2 Vol. XII, f. 34 i cf. Sterling, op. olt., p. 29.

3 Sets with facades are, of course, found (of. Larreneon, ... 
Compostions de antorimas all have elther no baokground, or a simple curtain, or mere rudimente of the Serlian design such as the houses indiosted on rlint and left in some of the onjrivings. The Italian companies who came to reance, then, from the $157 C^{\prime}$ 's onwards, yould seem from the ploturas to have used ourprisingly almple seto. One picture only the painting at Bayeux) has a facude-typa set with a soene behind it in perapoctive, as In the Teatro Olimplco; some only of the ensravings in the heouell Fossard and Conpoeitions de Rhitoxinue have ruxlants, and those primitivo indead, of Sarlio's design. Otherwise, only buck curtains are shom. Yot the leamed oomedioe that existed by the hundred in Italy and some of whtch the actors brought with then demend more complex sets than these: Bibbiens's Is Colandrta, for Instance, plajed at Lyor in 1548. In Italy, and doubilose in France too, more must havo been provided. Serlio himself, whose comic soene is doubtiees related to the sets actually used for suoh comedies, was in Srance from 1550 to 1554; If that wis so, surely porformances such es that of Almann''s Flora at Fontcinobleau in 1555 must havo used more then a simple back curtaln ar the primitivo

... The Brench stace, jussin), but only in ganres such as ontries and builets, nover in the straight theatre. - Sterling (p. 19) considere It a normal comnodla dell'arte set, but he does not refer to, and appears to f fnore, the visw in perspective through tho central eron. 
struotures ssen in the Compositions de Inhétorique.

It may well be that a troupe with falr finanoial baclings, such co the Confldenti playin for the Due do Joyeuse, would bave used some form of Sexl10's design but that no pictures of such performances have survived. As we hove soen, the 1conorraphical evidenoe forms so much a part of the world of the fine arts, and It may ecoily be that such performances did not find their artists. Fie should at any rite not nule the possibility out on mothodolostcal srounds, since there is internal avidence in the plays themselves to support the 1doa of cevolopod stage dosign and not simply a back curtain. I shall return to discuss the typo of set involved aftor exaining the plavs and their requiremonts in dotatl.

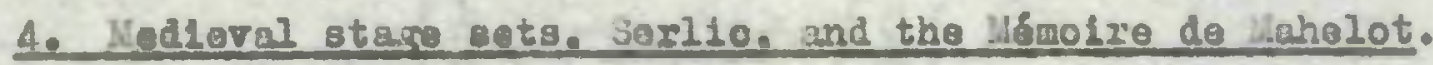

The question arlses: how fir are Sarlio's dosizns, and the arawing in the Mermolre de Hahelot, survivals from dieval stajo dosign? Joan Jsoquot seos a continutty in Mahelot, and einghusises the Italianato nature of his crarings: "Il a parfaitement assimile

I As far as I know, there exists no study of the stuze requirements of Italian learned comedies, using internal evidenoe. The one overall at $x$ dy of the genre, I.T. Herriok's Itellan comedr If lifi Ienalseenoe, Uxbans, 1960, discusaes the plays only as literature, with very little referenoe to staging. Juob a study would be valuable for the histozy of the Renalssance thoatre, and would be partioularly solid in that a very large nunber of taxts survive. 
lee prinolpes du deoor 'à l'ltallenne" ", while mentloning modleval elements suah es "manaiona' à olalre-vole rtrólent un interriour d'un caractore encore trè môdíral". 2 Frofessor Lawrenson, whlle not donying possible medieval elements in Kahelot, ostegorloally denles the Serllo-Nahelot links "There 18 not one set whloh oould even renotely be oonjootured to be a direot Imftation of Surl10." 2 The balance betwoen modieval and neoolassioal designs is in frot a delloate ono, both in franos and In Italy. We have seen how a humpralsts edition of Terenoe could fire lllustrations reoalling the sets for mystery plays and faroes. We have seen, too, how in France the faree stlll flourished In the $155 \mathrm{c} \cdot \mathrm{s}$, though by then a stat10 genre, and influenced the Plelade; and how outside the comto theatre, as late as 1547 a wholly typloal mediaval set could still be used for the Valonoionnes passion play. All the modieval genres - and hence prosumably the stage desizne associated with thom - oontimed throughout the century, at the same timo as the Ptenulseanco genres fainod their footins. Heo-classioal dewigns flourlshod overwhelmingly in what

$$
\begin{aligned}
& 1 \text { La vie thsâtrele, p. } 160 . \\
& 2 \text { Ibid. } \\
& 3 \text { The Erunch atage, p. } 87 .
\end{aligned}
$$


Profeseor Lawrenson oells 'par -theatricals's entries, maocrades, ballets and the likes lo not the reason for this that the 'paratheatricals' were new jenres, open to now ldeas of design, wheroas the 'straight' theatre, however new some genres such es trajedy mi ht appear to be, remained atill in a modieval tradition?

Tho kinds of nea-olassical design, derived from Italy, are ospecially asplicable to the straight theatre. Flrst, the fagade with a number of doors in 1 (t (five according to theory) with parts of a set bullt in perspeotive bohlnd the doors and visible through then. Th1s, above all, is still vialble in the peatro (f. $f$, 13)

011 mioo at V1cenzy For the Frenoh theatro (not 'para-theatricals'), a. we saw, there exists only one ploture of this kind of set: that at Baysux.

The other kind is in the desi ns assoolated with the name of Serllo. These flrat appeared in France in the translation by Jean Martin in $1545 .^{1}$ Serlio himself oame to France in 1541 and stayed until his doath in 1554 - that 18, he was in Frence at the time of the first performarioe of Jodelle's comedies L' Jurène and

1 Il arimo libro d'arahitettura II secondo libro di

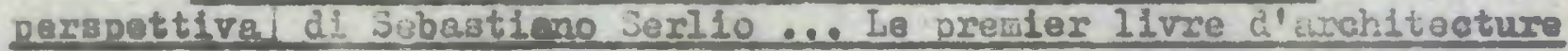
Le second IIvre do perapective de Sebastian jerlio... mis en lunzue Esaneorro par Johan Lartin, Paria, 2545. Cf.fj 12. 
La rencontace. Serllo discusses the three types of alcor spectfled by Vitruvius (tragio, ocmic and satyrio) and gives 1llutrations of model desifns for esch type, wh th emphasis on the principles of perspective. The buok of tho stage, for exauple, should be higher by onominth than the front. ${ }^{1}$

But these desichs, though they have the trapplnger of the Flenalasance in thoir palaces, citles, North Italian Renalsance towers, and so on, seom in their sssence to bo derived from the medieval thoatre. Nowhere in Vitruvius or other clasgloul sources is thete any referenoe to s sintral noutral space with buildings (or forests), supposedly realiatic, on three sides; ${ }^{2}$ whereas ouch an 1 doe is perfectly reconoilable with medieval strge dealen. The Vilenolennas (ef. fg. i1) staje, though nore sprecd out, uses the principlef so does the set shown in Fouquet's plcture of the martyrdom of Saint Appiline.

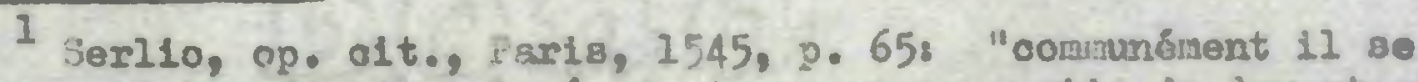
falot une platte forme, eslevée de terce en sa partie de devent au nveau de nostre veue, et la pastio de derriere plus haulte seuiement d'une neurlesme part."

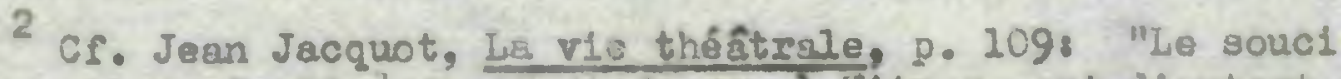
[de la part de Serlio] de 80 conformer à Vitruve est d' autant plus curlewe que la scène acrlienne, svec sa Brunde ouverture centrilo, n'a plus rien de commun aveo la soóns anticue, aveo $8 a$ figade orméo de colonnes et de statues et percóes de trols ouvertures. Il n'est pas molis curleux de voir Jean ilartin, dans son Vitruve, reproculre le plan âu théâtre latin par Fra Glocondo, puls, sans explication, les trols typos de déoor de 3erilo, qui résument la pratique dos théâtres de le Renalsaance. On $n^{\prime}$ aursit su sdrettre sveo lus de desinvolture lo divorce ce la théorie et de la pratique." 
Serllo'e desl na are not new, but reworkings of an old principle. In Frunoe in the late 16th century, Serlio's desins, even If consistently hailed as neomolassioal, would have has an alr of farillarity about them. For contemporary aulances, they would be a continustion of the moleval theatro, in a difforont suiso. That sume version of them was in fact ueed wlll appear from exaninetion of the plays themselves.

The next ajor plotorial document for the Irenoin theatre 1s the Minolre de Wahelot, ${ }^{1}$ nearly ono hundred years after Serl10' designs. Professor Lawenson Lnsists that Wahelot's sets are not directly related to Serlio, on the grounds that the esience of a Hehelot set is the indopendence of eich separate compartment, whereas Serl10' sots aro dosigned an unifled wholes. ${ }^{2}$ In vioy of the scanty orldenoe for the yours proceding lishelot, the qusstion probably oennot be finally settlod. ${ }^{3}$ But the essenoe of a liaholot set does not in frot necessarily 11 in in the incopendence of in the relationship of 1 ts oomponants, but rather in the exlatence of a

1 Bibliothèque nationalo, Is Fr. 24330. Nodern odition: Le ..émolre de Mhelot. igurent at nutres decorateura, ed. H.C. Lunouster, Par1s, 1920.

2 The French staxe, p. 86-9.

3 new edition of the Snolre 18 in preparation and may brine forward new eridence. 
noutral central space surrounded on three gides by stogre elements. This is always the basic design in wahelot, whereas there are not always more than one or two compartments: for example the specification for the anonymous Les trois semblables is simply "II faut que le theatre solt en pastoralle a la discretion du feinteur", 1 the corresponiting drawing boing of a single woodland scene; and Eardy's La folle d'Isabelle has one compartment only whose placing on stage is a matter of indifferences "Vous la pouvez mettre au milieu du theatre si vous voulez", ${ }^{2}$ an injunction which is in fict carried out in the drawing. There is no jusgling with a number of independent elements in sets such as these.

There 1s, of course, such a juggling in mediaval rellgious play sets, where the different mansions are in fact a series of different structures - even, in Fouquet's ifartrre de Sainte Apolline, a serles of different theatres, each with 1 ts om stage and roof. We saw above how one of these stiuctures may have given Ifise to the common type of farce stage. In the mobile religicus plays, ${ }^{3}$ the

1 Mémoire, ed. Lancaster, p. 79.

2 Ibid., p. 74 .

3 uhich were known to Grêvin, writin in 1561: "st quant à moy je suls de ceste opinion quo la Comédie a pris son nom $\alpha \pi_{0}$ Tw

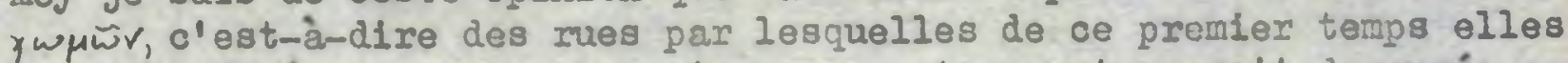
estoyent jouées: et semble qu'encore ceste coustume solt demeurée en ... 
different mansions wero on separate oarts and thus no: fired in ary permanent spetial relationship at all. So that to the extent to which Hahelot's sets do involvo combinstions of premexistont stago eloments, they may be suid to bo in a modieval tradition. Bach of jerllo's throe sets shows tils same baslo cosign (of a neutral central spiveo surrounded on three aides by atcuse elemonts), and moreover oan glso bo regarded as consisting of a number of compartmonts, unifled by the Itallan Into a more colverent whole than In some of Ifaholot's dusians. In all three sets, the 1 des of oompartments as opposed to a less diversiflod set is neither emphasiged nor excluded. His coilc sceno consists of seven buildingrs a church at the bacis, two houses and an $1 \mathrm{~m}$ (or shop) on the loft, and three houses on the right. ${ }^{1}$ All seven have doors, and all five houses have windows or balconies (or both) above. The shinpe of the Inn reminds us of the shop in, for instanoe, the drawing for Jurval's Acurite in the Memolre." Tho plays for whioh ho was desiming - and

... blandres, et Pais bas, où los joueurs da Comédies se fant trainer par les oarrofours bur des ohariots et là jouent leurs histolres, Comédies, et ieroes" (3rief discours: Mhótre cowplst, ed. I. Pinvert, Par18, 1922, p. 8).

1 serl10's text states that the houses are those of bourgeols oltizens that ono of them is that of a maoquerolle; ard that thore 18 a torple and a hostellexle (Sarllo, op. olt., Parla, 1545, cr. S. I. Holsjoer, L'htetolre do la mise an goino dans lo thóstre Ifagrals do 1600 i 1657. Paris, 1933, pp. 280-1).

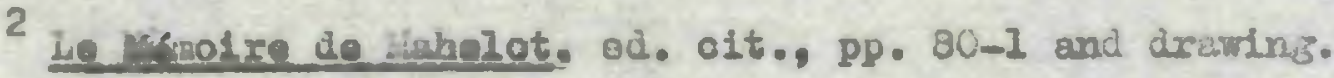


wo knor that he had prsctionl exgorlence in Italy - did demand compartments, and such compartments are perfectly competible with his sets. So would be the demands made by Fench comedies of the late 16th century.

It is diffioult to escape the conclusion that there is a continuity of stage de日isn in Brance without a brouk at 1500 or 15508 the medieval deaijns being modifled especially by Serlian oner, thomelves medieval but in reo-classloul dress, and onrlahed espocially in the early 17 th contury until we theo them in in Taholot's drawings, ioonosraphionl ovidence bolng leoking in between, but some support being found in the plays themselves. Ihe continulty is of course rolative. There are 80 many unionorns, and 80 many different kinds of starging in existenoe at this period, that it would be foollah to over-xate the importanoe of this continuity or indeed to do more than simply state 1ts existence.

\section{Performanoes.}

- There is no nead to ioositulate here the controversy, over half a century old now, to deolde whether Frenoh fen:issunce tragedies and comedies were Intended for the atage or the arohalr. Lanson's Investigetions proved finsily that the tragedles were in fuct performed, while in. Lebèctu's gableau gives us mary details 
about performanoes of comedies. ${ }^{l}$

The ovidenoe that we hive for our partloular plays relates ralnly to the early ones (up to 1570) and to the late ones (1624-28). The question of Jodelle's two comedies and their representation, as we sam in the flrst chanter, is a thomy one in 1ts detalis. But those detaile noed not conoern us here. It is estrollshed, on the tastimony of Etienne Pasquier, that is rencontre was acted.

Cesto Comodio [La renocntre], ot la Cleopatre furent

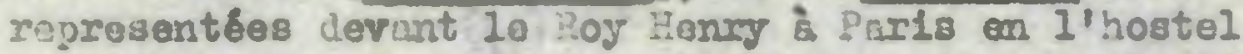
Le Relms, arsog'un srand applaudissoment de toute le compacrie: Et depuls enoores an College de Boncour, où toutes les fanestres estclent taploseas d'uno Infintte de personoges d'honraur, et la cour al plaine d'Broollers que les portes du College en regorgeolent. Je lo dy corme oeluy qui y estols presont avocg'le grand Iomebus on uno mosmo Chambro. It les entroparleurs sstolent tous homes de nom: Cat mesme Rency Belleau, at Jean de la Peruse, jouolent les prinolpowx roulets. 2

Onoe, then, at the Hotel de lelms, once at tho Collès? ce Boncourt; both times, presumably, on a stese propared or lmprovisel for the ocoiston. The precise date is uncertain, If. Balmas, in hls edition

${ }^{1}$ Cf. esp. E. Rigal, De Jodelle à Hollère, Paris, 1911; Q. Lanaon, 'Etudes sur 108 ori gines de la tragldie olassivue en France', Revin d'hlstolre littéralre de la Franee, X (1903), 177-231 and 413-6; R. Lobogue, Tableau de la comédie frangaise

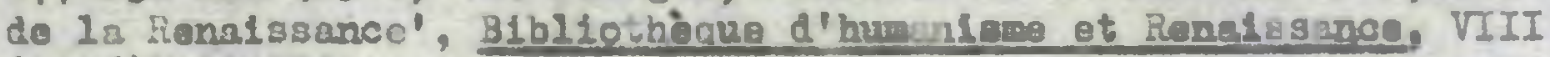
$(19 \cdot 6), 278-344$.

\footnotetext{
p. 741 .

$-2$ Les recherahes de la Frnoe, Paris, 1611, VI, V11,
} 


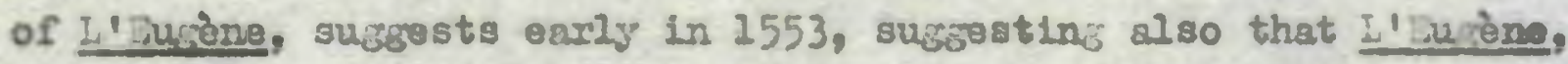
whlch he dates very precisely in the last fortnlght of joptouber 1552, was probably also repreaented in a collegu.?

Jodelle's example of an intejrated performance of a tracody and a oomody together, in a floyal and acadomio milieu, wao followed by Jaccues Grévin a fer years later. Problemo of dating arlise hore al30. Grofin himgelf telis us that ha tresomiare, though put off (for reasons whioh are not row clear) in 1557, was performed on 5 Februsxy 1558 (new style 1559) and Les esbahls on 17 February 1560 (n.8. 1561):

Ceste comodie [La tresoriare] rut falcte par 10 o ommandement du rol Iienry II pour servlx aux nopoes de madare Cleude, duchesse de Lorraine, mals pour ourlques empeschenans diffárées ot dopula mise en jeu à Paris au collège de Beauvsis, après la setyre qu' on appelle comanáoment los Veawx, le V. do férrler H.D.LVIII.2

Ceste ocmedie [Les esbahls] rut mise en jou au collège de Beauvais, a Parls, lo XVIIIe jour de février L.D. IX après la trazéde de J. Cósar et leo Joux sstyriques, appolom commúóment los Veaux. 3

so evidanc3 aurvires sbout the staging of Le faubert Ine, if that

$$
\begin{aligned}
& 1 \text { Stienne Jodelle, Jujue, ed. J. Balmas, M1lan, 1955, pp. 5-12. } \\
& 2 \text { Guoted from Jaogues Grévin, Thêtre ooublot, ed. I. Pinvert, }
\end{aligned}
$$
Paris, 1922, pp: 353-4. 
was indoed a thlxd comody by Grêln (see Appendix B).

Jean-Antoine de Balf Included details of the performince

of $\mathrm{hls}$ 3rave on the title page of the first edition:

Le Brave, comedie de Jan Antoine de Balf, jouee devant le Roy on l'hostel de Gulse, ì Paris, le

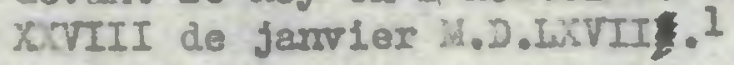

The occesion was an important one, and ajain, in a royal and acadento setting; ajain, in a building with, presumably, an lapprovised stage. The first odition in 1567 fives the 'chantz reolter entre les actes de lis comodie' by fonserd, Belf himself, Desportes, Philleul and Bellear; but thuy havo already vanishod by the 1572 edition.

No performance of I' elonugue is lenom to us, only a note about its translations the oxleinal manusoript, now in the Bibliotheque Nationale, beard the note in a l6th oentury hand, probably Balf's oms "Aohevie Leiderain de Noel devant jour 1565." Porhaps It wo intended for a whristmas entertainment, or for a performance in the early part of 1566.

Sxternal evidence about Plibiado plave, then, fives us a pleture of a spoolfioally Univeralty milleu, sometimes with Jalvaraity jokes or references (the Irotonotaire in Grevin's La tresortione), and ith fioyal patrorige. Joan da la Taille tells us that he and

I J.A. de Balf, Le Brave, Faxis, 1567. 
his brother Jacques wrote plays in thoir youth, while students: that 1s, assin, in the milleu of the University of Parls. The stares were presumably prepared for the oocastons. There is no reason whey they should not have been elaborates after all, the set at Vicenza was prepared for 3 single ocousion, and we have all seen present das sohool and University productions whose sets ure by no ans simple or 1mprovised. Dxtermal ovidence takes us no furthor.

To thase royal and soaclemlo performances wo should add the performanoes of Italian plays in royal and aristocratio circles: B1bblena's La Celandxie in 2548 at Lyor, Alamann''s Jlors in 1555 at Fontainebleau, Forneris' Ancelios in 1584 at the house of the Dnc de Joyeuse at Paris. The firist took place in the 'Grande salle de saint-Jean', a hish raulted room in which tha set was bullt by the Itallan Ifamnoeolo, of jerlian type, speciflonly using porspeotive. ${ }^{1}$

Betwoan La Tallle and the $1620^{\prime}$, we never know when or where any Glven comedy - othor than Aszellon - was performad. Gerard de Vivre tells us that soting in sohools is pedagoglo.2ly

Is.H. Holsboer, L'histolre de la miee en acine dans le

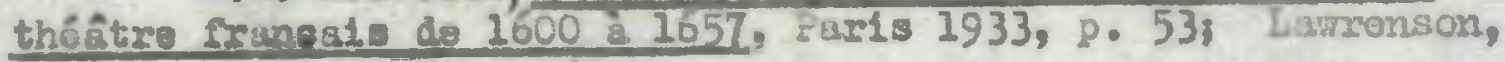
The French stace, p. 126. 
effective, oven giving sterge directions in some detall for performanoe, and we may perhaps conclude from the wany editions of de Virro's plays (in which stage direotions always appeared) that they were found useful for their purpose and so were in fact acted in sohools. Franopols d'Ambolse tells us that his comeles were "Voües et receïes areo un plaislr indiclble", but does not sey when or there. Gabrlel Chsppuys makes his Poëte say

La ohose representee au tili ainsi qu'elle his esté falte, ha plus d'energie et d'effloace, que oe quil se doclare par parolles.l

but this 18, of ocurse, not conolusire eridence for performance. i. Lebesus's 'Tableau' Inoludes references to nany performances of 'oomedles', but the term is notorlously general and can refer to moralities or farces or other genres as well as to strlct cumedies.

In the Britioh liusoum oopy of Larivey's Le morfondu, the 1579 edition, the Drematis personas bears a l1st of aotors in a late 16th or early 27 th century hand, which appears to show that the play wes actod, but the actors prove diffloult to 1dentify. The list is as follows (the two Il ght-haind colume beine printed, the rest in mamusoript)s

1 Gebrlel Chappurs, Les inondes Celestes... de Danl, Lyons, 1583 , p. 666. 


\begin{tabular}{|c|c|}
\hline In motte & PHIIIPPES \\
\hline michel & CLIIRS \\
\hline bretone & LOYS \\
\hline most1er & L. LABIRT \\
\hline la fonteine & CHALLTS \\
\hline floury & LAZMRE \\
\hline fonteine & AGNES \\
\hline bretane - & AGATHE \\
\hline lanoelo & LEOER \\
\hline 1 a motte & JOACEIS \\
\hline inlohel & HELAIN: \\
\hline
\end{tabular}

Amourewx.

Servante. comparmon de Phillppes. servitaur de phillopes. Asloureux. V1oillard. sa Serrante. fomse de Josohim. serviteur de Charles. Laquals de Lazere. Vlelllard. Flepce de Lazare.

In the $1630^{\prime} \mathrm{s}$, a young Erangols de is Kotte oculd act Philippes (but he ls otherwise not hoard of unt1l 1641), Floury illght be Bloury Jaoob, by this tims cortainly apt for a vielllard's part; mlchel oould be inlohel de La Chappe (d. 1642), whose dauchter La Motte later marrled; La Fontelno could be Itienne Fuffin, oalled La Eonteine, who was aating up to 1638 ; Brotone could be lloèl Le Broton, celled Hauteroche, who was born about 1616. On this asoumption, hostier and Lancelot oannot be ldentifled at all. - One other performance of a plag by Larivey or d'Aubolse may have beon that of the Chattean de jougy which we disoussed in chapter 1. But in foneral, the referen:as vare vory soattered. Perheps more evidence once existed, and the notorlously ephemeral nature of reoords of this kind is to blame.

1 Cf. G. Longrbalen, Dlotionnaire blosreaphiaue des combafens Franpals du XVIIe sleole, Parls, 1961, paselm. I an hoping that II. Yongxéden himself may be able to cast som 11 ght ox this list. 
The performance of comedies in Hardy's time has been ably cilsouabed by ime Delerkauf-Holsboer in her 'Vle d'Alexandre Hardy' and by Professor Gill in his edition of Les remoneurs. Their conclusions were, as we saw, that Ilardy certainly wrote comedios and that in fact the very question of 'copyright' in connection with atage performance was probdly responsible for the fallure of these plays to resch print. It was the troupes of Valleran le Conte and later of Fierre le imessier (Bollerose) and V1lilers, with hardy as porte a seges, that acted such oomedies. Supporting th1s evidenoe, we lonow on the testimony of Thomas Platter that Valleran's troupe, in 1599, speolfically parformed oomedless

A l'hotel de Bourgozno il y a un comedion nominó Valeran, enjag par le fiol. Il jous tous les jours, après lo repas, une oomédie on vers frangale, et débite ensulte une farce our ce qui pout Etre arrivé de dróle à Paris, on falt d'smourettes ou d'autres aneodotes du wếne genre. ${ }^{1}$

Platter's distinction between 'comosde on vers frangsis' and

' farce' 18 quite olear.

Les ramoneurs itself is conneoted with the Hotel de Bourjognes that 1s, probably with the 'Comediens du l.ot', a oompany inoluding not onlyectors of Valleran's kind, but also the three

\footnotetext{
p. 316 .

I Translated from the orifinal, olted by Lebague, 'I'ableau',
} 
furce actors Oros-Gulllaume, Gaultier Garguille, and Turlupin. The autior of the play makes the valet Martin says "Voila vrajement un bel exemple à ros dieclples quit verront representer l'histoire de cea bellos anours dans un hotel de 30ursozno", ${ }^{2}$ a line which could have its full effect only in a performanoe in the Hotel de 3ourgogne 1tself. W1th this play, indeed, we aro returning from conjecture to frot; and it whe delite, played only some five years later (1629-30), that eatablished (as Corneille tells us in his Exangn) the troupe of liontdory at paris, to begln a period in which the public theatre in Irance was to oome once more to an aoknoiledged aligniflcance.

6. The evidance of the plars $\quad 1550-1570$.

The internal evidenoe of the plays themselvee has not, as far as I know, been used before to yleld informatlon about stage sets, perhaps beoause thelr evidence, as posisibly non-dramatlo works, has been mistrusted. Let us put this objeotion aside, for the roment, and exarine what information they have to offers way then decide upon its value.

For I'Surine, two oompertments only are needed: the houses of Gulllaume and of Jujgene. I, 111 is set insice Qulllaume' B house

I IV, xz ed. G111, pp. 133-4. 
("lials comment? qui entre oéans?/Avez-rous lalssé l'huis ouvert?")

It must have been a door through which lossire Jean enters, and it has an upper storey (III,1i1). It has a garden (I,11i), but this noed not nucessarlly be represented on stage. Elugène's house needs $a \operatorname{door}(\nabla, \nabla$ "Voylà l'abbé ot mon Helène/Devant la porte", "Sus, ontrons"), but no action takes place in the interlor. Forlmond's house is referred to (V, 11 and IV) but need not be on stage. So, short of improvisation, there must be one compartment with an Interiors one with only a door (II, 1).

Jodelle's other comedy, La rencontre, ls lost, but we do know something about its staglng. Etfenne Pasquier says of its

La Zencontre ainsi appell6e parce qu'au gros de la meslange, tous 108 personneses s'ostolent trouver pesle-mesle ossuellement dedans une malson, fuzeau qui fut fort bien par luy deneslé par 1s olosture du jou. 1

The soene where this confusion takes plsce, with all the characters within a single house, 13 presumably shown on-staje, like the scene inside Gulllaume's horse in i' wisine. It would be diffloult to improrise. Stafing clearly is of some importanoe when the very title and basis of the plot are derived from $1 t$.

1 Les rooherohes de 18 Ixinnoe, Paris, 1611, VI, V11, p. 741. 
In La tresoriare, the Trésorier's house is the only essent1 is cokyuriments it has a door whioh is knooked at and used (III, $v_{;} I V, 111$, eto.), and an upper storej 19 referred to. The whole play appears to take place outside this houses all aotion within it is reportod. One wijht ouppose from III, 111 ("II est chez lo aire Sulpioe") that II, 111 took plsoe at Sulpioe's houses but Constanoe's appearanoe in that soene sujgests otherwlse, that it was ruther at the Trésorier's house.

Les esbahile is almilarly undemanding. (tnily ono coipartment, Gerard's house, is needed. It has a door through whioh L'Adrocat enters, and emerges (III, IV, IV, 1 ) and an upper storey (III, V "Jo montray Jusqu'en la chembrette") whioh is probably shom on-stage, since Panthaleone appears to doliver his serensites to a window above In II, 111 and $\nabla, 1$. II, 111 defindtely tokes plooe in the stroet, "devant I'huge du sire cerard". Otherwise referonces to place are ofter improcise. Ho action nocessarily takes place within Gerard's house. Compartments for Josse and Claude would be possible, but the neutral opace could also be used for them. Although, as we saw, there is no a priori resson why a college production should not have an elaborate set, it doss appear that Gróvin has chosen to make only modest demands on his otage-builders. Unlike Jodelle in both his plays, Grérin does not set any of his action inside a compertment. A single 'flat' with a door and window in 1t, or even a back ourtain 
with an eperture, would bo adecuate for elther play.

In La reconnue, action once nore taites place lnglde a oompartment. In I, 11, Madame refers to kitohen equipment ("ce chaudran", eto.), so that wo are quite definitely inside the kitchen. The kitohen has a door cormunioating with the rest of the house, since Janne asks for 1 t to be closed In IV, V. There is also a door from the street into the house, which Janne openss it may lesd into the iftohen, but this is not absolutely olear and would in any case be odd on social grounds. There are a rool or fooms above (I, 11 "Antolnette, descendez") and a window $(\nabla, 1)$. One other compartment 1s esecntial, the Volsine's house (I, IV-Vi IV, 111). There is definitely a noutral street area (act $V$ ). An extra compartment for L'imoureux (IV, VI) mould be possible but is not essential. So - asain, short of improvisation - the rangurements are the same ss for L'issone: a 'street' area, with two compirtments, sction tairins place within one of them.

The set for Les corclvaux a.Iso requires only two compartments, with a street in front. The compertments are Jacqueline's house and Fremin's house, In a restiential pert of Paris (II, 111 "Jo m'en vals ì la villo"). InIII, 111 Benard is outside Jacquelino's ("lo logis oì se tiont mon f1ls") and In III, $\nabla$, without montion of his having moved, he ls outside Fremin's ("Jo ne demande autre ohose, entron dedans"), so that the houses any be supposed to be noar each other in 
terms of the play 1tself. Both of them have doors . Fremin's has a back door as well (I, 111, I, 11, etc.), but it 1s evidently supposed to be off-stage (III, 111, etc.). Whuch of the action takes place speciflesily in the street, and none within the houser. Le Nogromant is of course a translations but in any case it follows the pattorn in reguiring two cospgrtments, with a street in front. The two compartments are supposed to be near ench other in terms of the play $(I, 11)$, and there to e referenoe $(I V, \nabla 1)$ to "ces malsons prochaines", whioh muy be mers flats.

Balf's two plays follow the stagins requirements of their orlsinals. Le brave in partioular requires two compartments: the houses of Talllebras and Bontans (corresponding to those of Fyrgopolynloes and Periplectonenus in the Miles plorloous), Jut all the rotion takes place outside them.

The stage requirements of these first comedies, then, are quite consistent. There are five original plays, three translations and the missing Le zencontre. The most that is needed is a noutral space with two compartments, with actlon inside ono of them and door in the other (L'Jusine, La reoonnue). The least is a neutral 8pace with ons oompartment wh do door (Grérin's two plays). La Tatlle's two plays need two oompartments, but no actlon takes place 
Whin them, Jodelle's other play, La renoontre, has aotion Fithin a compsrtment but it is possibly the only conpartment - wo cainnot knors.

This is not the staging required for Terenoe's plays at any period, for there no action is arer seen heppening inside a house. It could correspand to the décor of the 1llustratlons to Lenalasance editions of Terenoes in those 11 lustrations curtains are used and sometimes the drawn surtain reveals a character inside, 1 a procedure that could be followed for L'Juzene and La recomma. But the décors of the Fercntian 1llustrations are essentlally rows or Broups of numbers of compartinents, whereas here there are only one or at most two.

Nor has it any Itallan charscter; ${ }^{2}$ nor 18 it the staging of the farces. In reading farce, one becomes used to the rertilinous changes of sceneedependin coubtless on improvisation, whereas here the atmosphere is different, calner, rether suggesting that an actual set is being used than laplyin improvisation.

1 For example, in an 1llustration to phormlo in the 1518 Venios edition, reproduced in Lawrenson and Furkis, 'Les editions lllustreses de Terence', 11g. 13.

2 The farce-1lke character of L'irgène is quite at variance with Serl10's elaborate comlo scene, which 3 almas nevertholeas reproduoes in his edition of Jodelle's play. 
It doss seem that a klnd of set 1s lmplied, espoolally In L'Dukine a? La recomnue, and alo0 in I.es oorrivaux and Le rencontre, which is different from anything known to ws fram plctorial evidance. A reusanable solution could be that the model for these weitere in conoalving the setting for their plays was the Perentian 111uotrations, but that since their plays were 10 s complex structurally than Toreno' 3 , so were thelr sets. A raxy almple design for I'Jugène inlght be:

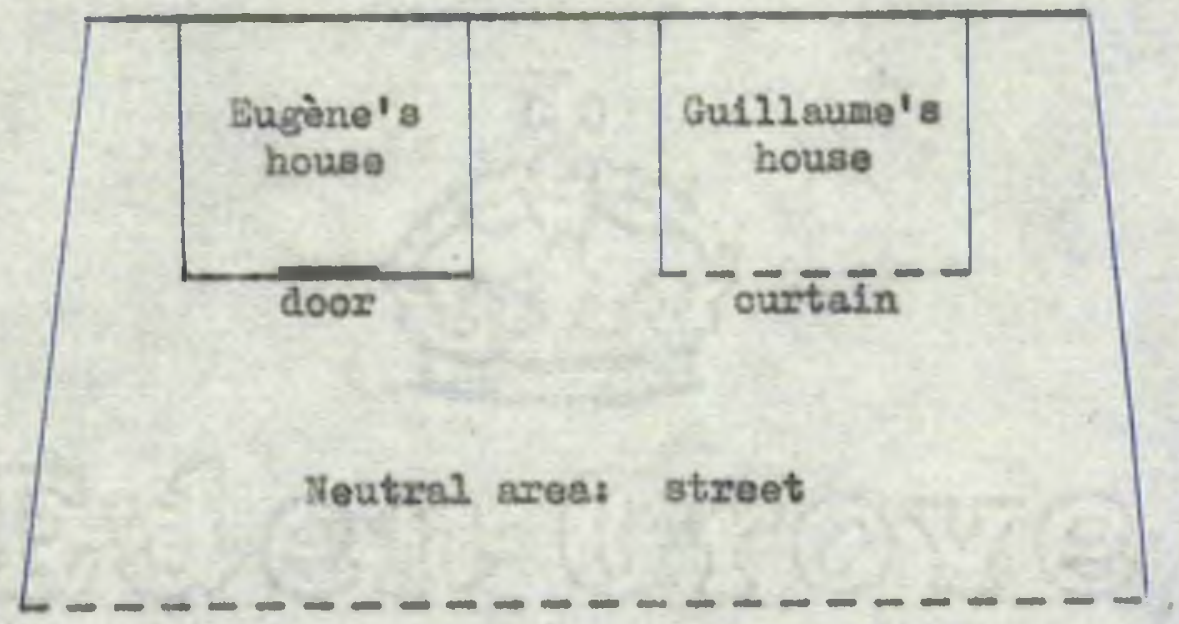

2. The evidenge of the nImat $1571-1630$.

De Vivre's la slollte nuotlale, as we saw, is the rlret oomedy in Frenoh to laltate the Italian plavero nowly established in Fraroe in the $1570^{\circ} \mathrm{s}$. Already 1 ts ataging 18 afferent from that of the earller genaration. It is not - laborates but it makes full use of the decor implied. There 
18 a window above - Srom whioh a servant, Pardallisa, throw

down water as it were into the streot, shouting as she does so "Garde I'eaue. Garde I'owe". There are pillars supportlog the "fenestrages" or balcony - and a misked Ilowre tho stends hidden as though he were one of the pillars:

Cependant qu'1l ohantera, sortira un autre aocoustré leglerement ayent un masque devant

1s faoe, lequel se mectra devant le porte tout dobout en un coln, là ou l'autro lre chanter, et se tlendra 11. coy, come 81 c'estolt une colorms à soustenlr 108 fenestrazes.

Thlo active use of stane elements seem different from the nore passive use seen in the comedies of the earlier generation. There is something of it in Larivoy's Les esprits, Two compartments are noededs Severin's house and H1lalre's house. They are near each other in terme of the play (III, 111). Sevarin's naeds a door and a windo above, and both of these are actively used, the first in III, 111 where the door can be hoard opentng, and the sooond in II, 111, where tiles are throw down from 1t. Hilalre's needs only a doox, through which Frontin enters and emergas ( $I, V)$, It also has a 'liugs de derriere' (III, 11) but this is not nocessarily on stage. The otago must represent, or at least give the 1IIusion iof, two or more streets (I, 11 "Je 18 vour appelor levant qu'II change de rue"). Near Severin's house there is a 'trou' in whlah ho hldes his purse (II, 111, otc.). Gererd's Ielat1on's house, and Iuffin's house, 
are referred to and suld to be in the same strat as each other (IV, 11), but are not neceasarily on stage.

Tumèbe's Les contens roguires three compartments: the houses of Girard, Louise and Honsieur Bartole the lanyer. ${ }^{1}$ the flrst noeds a door, and in IV, $\checkmark$ a winiom above $1 \mathrm{~s}$ 1mpllod ("Cui est limbas?). The second needs a door whloh can be locked wth a key (1t is so looked at $\nabla, 111$ ) and a window above whlch opons and closes $(V, 111)$. None of the action other than reported action needs to 80 on Inside Loulse's house, ${ }^{2}$ but we know some things about its interiors it has a 'petit oratoire' (III, F11), a 'sallo' below (III, Vil, otc.), and a rcon or rooms abovo (I, 1 "Gr' an se despesche de descendre"). The 'salle' has vilndows opening into tho gour (act IV). The house also has a 'hws de derriere' ( $(, 11)$. Monsieur Bartole's houre needs only a door (IV, Ir-V). - These three compartinents are supposed to be noar enoh other in terms of the play itself (in III, 111 Basile, who is

1 Dr. Spector, in his edition of the play, p. $200 \mathrm{rrl}$, only sounts two, omitting wonslewr Bartole's house. AI though it is true that in production this house oould be set off stage, there seems no resson to suppose that it is not a third compartment on stage: of. IV, iv "Won frero, allons trouver ce fareux adrocat onolour Bartis, quil demeure tout loy-contre", and IV, $\checkmark$ "Tenez, la royla quil sort de chez lionsleur Bartole."

2 Part of I, 1 could well be set inside, but î. Lebègue is wong In assuming this to bo essential ('Unité et pluralité de lieu dano lo thêtre rrange1s 1450-1600', Le 110u thfêtrel à le Renalosanoe, Paris, 1964, p. 352). 
outs1de Girard's house spesks of the door of Loulse's house as "coste prochaine porte", while from IV, $\nabla$ we Gather that 4. Martole's house is near Glrard's). Mlrard's house appeare to be a were Ilat, because In IV, v Girard and Dustsohe speale in the stroet, rather than In the house, for no drematic resion at all the only reason that sueserts 1 teelf is that the set does not allow them to enter. ${ }^{1}$ - As well as the main neutral space, there are at least two 'ruelles' $(I, 1)$. In $I, 111$ Rodomont hides under an 'aurent', but $V$, iv referring to this same scene soys that he hid behind a 'oherrète', a cart, this 18 an inoonsistency, but one or other, or both, is neoessary.

Lee Nespolitaines almlarly needs throe oompartments: Angrilque's house, the Collàse des Lambards, and the Inn the Bsou de France. The first is supposed to be in the Faubourg saint-Geriuln $(I, 1)$ it hes a doox, through which exit casille, muning (III, v1), It has a window (II,111) s and it probably has a 'haute gallerie', otherwise Gaster's Ile (III, 1i1) would have no point. It has an upper storey where Anerllque and V1rginie live (III, V111). To ootion takes plaoe within 1t; indeed, in III, ril1 it seems old that the action should continue outside the house. The Collège des Lombarc's

1 Dr. Spootor arggests in his edition, p. xoxvil, that the reason is to preserve the unity of place. Thls theoretioel reason may well be corredt, the conclusion rejarding the staging is neverthelees also valid. 
has a windows in V, iv the Innkeoper oalls Camilles "Je le ra" appeler par la fenestre", and Camille appears there. The liscu de France has a door through whloh the innkeeper enters and emergra $(\nabla, 111)$. - The strset is used $(\nabla, x$, oto. $)$ as poutral territory. - Cther compartments are posible, but not essential; one likely one is Auguatin's house, for in I, 1 he 18 oallins out to Loys, who, precisely, 1s staying at hom, and another possible one is the house where Dlechos is staying (II, 111, III, Vi\} I, 111). Other places are named, whioh the characters vialt it thin the time of the ilay's actlon, but they are not on-stage: the patissurle (II, II), Isaboay's house (IV, IV), etc.

The evidence of Fornaris In elioe and 3mino's Il Candelato, both published in Jranoe, merely supporte our data so fars neither presupposes a etase in any way different from thet of Les contone or Les Heapolitalnes. "L.C."'s Ancelique is a olose translation of Anvolica. As we sew, It is doubthul whether Lasphrlse's louvelle tractoomique was over acted, but if it were actod, it would be an exooption to the practice so fary it would noed five oompartmentes Dominloyue's house outside Paris, with a gate that opans; the magiolan's cave; a olty sate of Faris, again whioh opens; an inn with a window, a door that opens, and a scene inside the Inns and a prison.

Perrin's Los oseoliers is far simpler than any of the 
plays we heve been discussing. As we have seen, it stands outside the Itrifarnts tradition, and the stito of the comadla arudita 1s foreign to 1t. In this, as in other ways, the pley is a return to other, simpler, forms. There is only one compartment, Marin's house; this has s door which can be heard opening (II, 11). If Friquet in I, $\nabla$ is not speaking in seneral terms, it seoms that from the outs1de of the house one can seo a staircase, a door and a window. Some of the sotion $1 \mathrm{~s}$ definitely in the street (IV, $\nabla)$. Las dosaulaes, although an udaptation from the Itallan, is also almple. Only ono compartment is essentials Grogolro's house in a resident1al pert of Toulouse ${ }^{1}(\nabla, 1)$ III, $\checkmark$ "lion père dolt retourner ... blentost de la ville"). It has a door through which Louise enters and emerges (II, 11, IV, 111). III, $\nabla-\nabla i$ could take place within the house, but noed not. Other possible oumpartments are the volsine's house (II, 11), Prourentard's house (III, IV) and Passetrouvant's house (IV, Vi11); any of these could ba on-stage, but need not. Some sotion definitely takes place in the street (III, 1 and IV), anc the stage seoms to have tiro streets or at least thelr appeazunce (III, 17 "1I a jà gajón l'sutre sue"). Troterel's two plevs, 11ke Les esoollers, look baok to farce in many ways, and not least in their staging. The awarenoss of stage

1 Hot "Valance", as A. Cloranesou states (L'Mrloote on Drange. vol. 1, Paria, 1939, p. 302). 
Sécor which wo saw in La fidelité nuptiale and ies esprite is absent hera, whal we havo only t3oasional roferences to bosic st s, - lements such as a door (Les corrivanx, II, 1V). One of the rare references to s ourtain in Frenoh Rentissance cowady is in Leg comiveur. III, 11i.

The set for Les ranonours, on the other hand, 1o relatively complex. It consists of four compertments, every one of thein this time with doors. The play opens outside the Captaln's houso, "oe

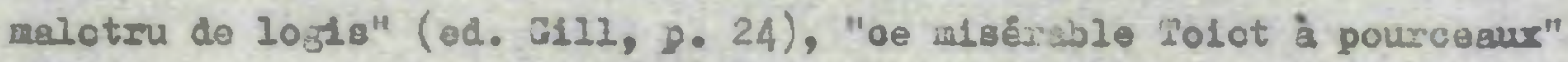
(p. 4) it has a door out of which caleffre ohases the crocheteur (p. 63 of. Les Jaspolitalnes, III, v1), and a window above (pp. 13, 32). Part at least of III, ir takes place within the house, when the chimney is swepts this ls a room geperate from Diane's room, the one whioh has the window (p. 91). - Separated from the Captain's house by a drain or 'rulsseau' (p. 21) is Dame Bomne's frult shop, which has a window 'opposite' (p. 43) and commanding a view of the Captain's house. People 'so ins and out of her door (pp. 70, 72). - Claude's house has a badroom lnalde (pp. 120-134) in which, as in the Captain's house, action takes plisoe; the door of the bouroom 18 even broken in (p. 127). Besilos this, there are referenoes to a 'Chambre de nant1seoment' above (p. 137), a 'salle' (p. 150) which is possibly the same as the 'ohambe' (8.97) but whioh is speolfically not used (p. 150), and a 'porte de derrierre' (p. 127). Jinally, there 
Is the house of Dawe Koulse, the lingère, whioh has a windon (p. 153) and a room above (p. 1.45). This is certainly the most compllosted set of any of our playos unless a very great deal of Improvisation were employed, the bare stage of the getel de 3oursogne as we see it in 30sse's print (reproduced, for example, frontispiece) in GIII's edition, (would bo wholly insufficlent. If the plas was scted at the Hôtel de 3ourgozne, as it would appear (p. 134); and Introduction, pp. ock $\left.f_{.}\right)$, thon we surely must sssime a more olaborate set, slmilar to those in tho kehelot drevings. As for the arrungement of the oompartments, we know that the Captain's and Borne's houses are very near each other, that Ph1lippe's turns left out of the captain's house to go to Clauce's (p. 87), so that Glaudo's mast be on stago left of the Captain's; and that the Ingire's house is probably not meant to be very far from Claude's, as Galaffre ousily follows Martin from one to the other. Finally, the number of references to streets, partloulexly small anes (pp. $71,73,87,92,119,143$ ) suj3ests gaps botwoen the compartmants, perhaps alleys as in the Vlcenza set. One arrangeof the whole alght bes 


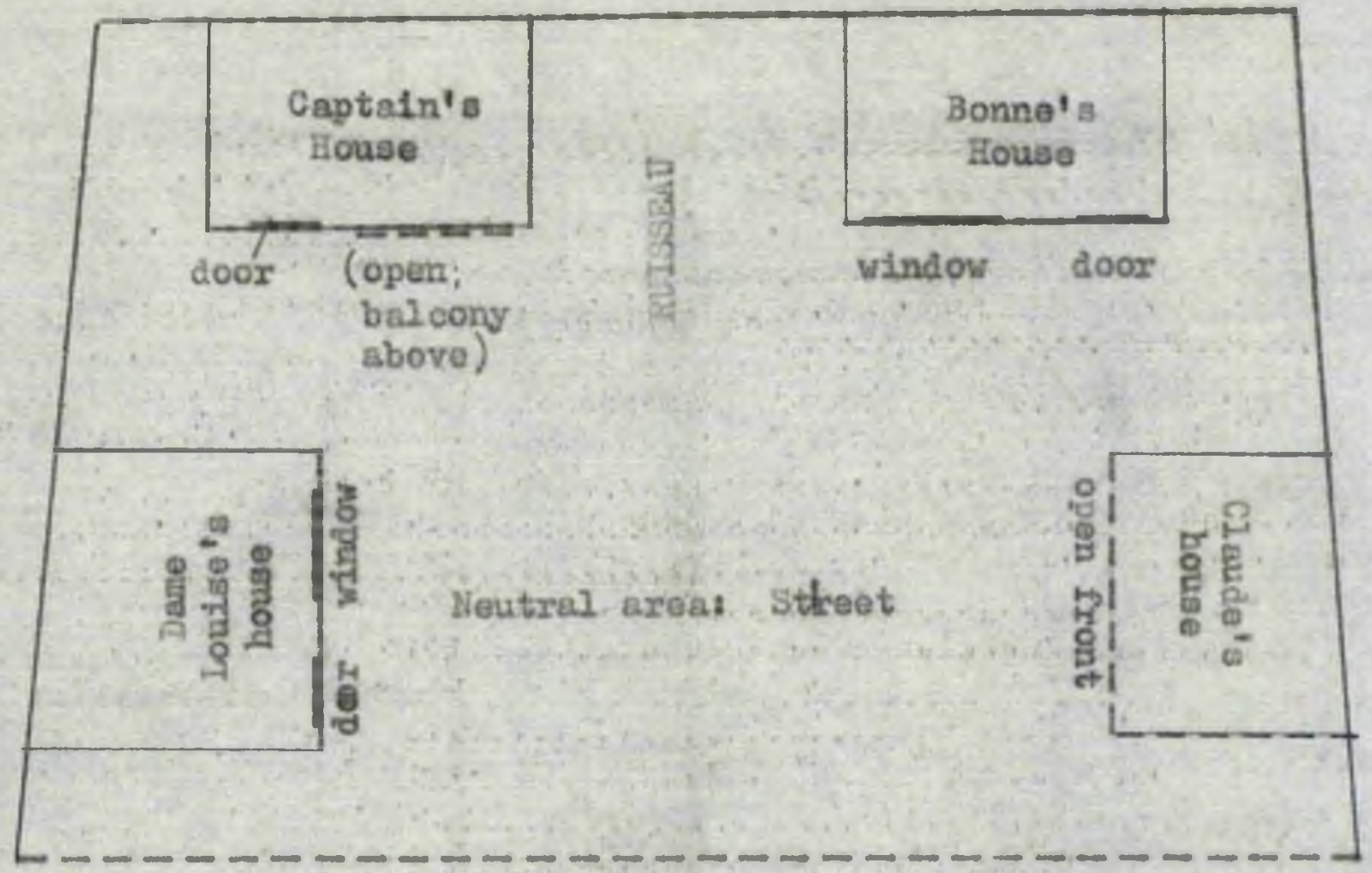

Cornell10's isslite, written in the same cooade as

Les ramonours, atands firmly in the tradition of multiple deoor. In the examen whioh he published in 1660 , he wrotes

Co sens cormun, quil e日bilt toute ma Regle... a'avolt dorilié assez d'everelon do oet horrible dereglement quil mettolt Farle, liome, of Constantinople sur le mosme Theatre, pour redulre le mien dans une seule Ville. 1

The three necessary oumpartments - the houses of M6I1te, of Cliton, and of Tirsis and Cloris - are indeed supposed to be in the tome but novertheless in different quarterg and far

1 Goted from Plerre Cornellle, Lólite, ed. Luxio ioque日 and Llarion Ilèvre, Lil1e and Genera, $1950, \mathrm{p} .135$. 
enough away for Tirsls never to have seen Melite before (Ecamen: "oes quartiors dolvent estre si eslolgnez l'un de l'nutre, que les Actours avent 11 ou de ne pas s'entreconnolotre" ${ }^{1}$ ). He saw that Tumèbe in his play has minimised the artifioiality of tize conventions but Corneille, forty years later, here otill acoepts 1t. Later, in the Bxamen, ho was to conolder it a fault that characters were allowed only a short time to move fron one uarter to anothers but of courise, in taras of the convontion, there is no objection to this. ${ }^{2}$ - Mellte's house, like so many others, hes a window at first floor lovel at hioh she appoars (II, vill "Ile parolst eu travers d'une jelousie ... Mellte se retire de Ia falousle et descend"), Clorlg' hes a door (III, vil "gllo Iuy forme 1a porte au nez").

What are the constent foatures of this oonvention?

First, It is quite olear that a form of d6oor aimultane is involved, a single set with number of hicises..$^{3}$ and the stages in the

\section{Ib1d., p. 138.}

2 Thus Tirsis in aot I between scenes 111 and $v, 82$ lines, Tireis in act II between scenes $\checkmark$ and v111, 84 lines; Cloris in act $\nabla$ between scones 111 and $\nabla, 541$ ines.

3 Is It necessary to refute the 1 des of successive chanjes of scene? In the 19th century, Thoms Love Peacock, translating GIIngannat1, wrote: "I hare ... marked thres ohanges of scenes is atreet with two hotels and the house of Ghorardo. A street, with the house of slaminio. As street, with the house of V1reinio",... 
1llustrated editions of Terence will no longer dc, because they do not hure windows, doors whioh can be heard opening, and so ons wh1le the elaborate set of Serlio's comic scene, with its ohurch anl tower, shop and flve or more houses, is never necessary.

It 18 olear that a ohange has taken place with the coming of the Italian troupes. From Jodelle to La Taille, the maximum number of compartments needed wgs two, with sction tailing place in one of them (I'sugene, La recomme). From Larivey to Les ramoneurs, two to four or even flve compartmonte are noeded, with action Lnalde the In Les renone urs, and the compartments need to be nore coaplex. But the staging seems to have altered only in dezree ind not in essenoe. The excmple of La Tallle should warn us a alnst assuming that a sharp broak occurred overnight. Ia Faille's models were Itallan (though admittedly he wrote before the Itallen troupes came), but still, as an adifirer of the Flelado he demands no more complex sets than they do. The Itallans aoj have scored a great success in France in the 1570's, but the stage demands of French comedy do not seeu to bave altered - ossentially as a raøult with zorxin and even Godard, adaptor from the Italian as he was, it was still possible to fotum to a

... an orror which has found its way, whout coinment, into a modern reprints The centus of the Itallan theater, Now York, 1964, p. 100. 
set demanding only a sinjle compartment. This continulty supports the particuiar ldeas about cosifinutty of stage design which I susgosted in part 4 of this chepter.

Separate compartmente, then, with a neutrel street area Qreans for Le brave, are used throughout our perlod. Whe tom ls alwavs Furis (oxcopt $C$ Toulouse for Les desauisez, and Saumur for L'arare cornu), alt tough references to the provinces are nore frequent than they will bo, for exumple, in post-ilchelleu olays. Some of the action takes place in the street, and sometimes it is speclflcally made clear that the charactero are In neutral territory and not outside a spociflc oharacter's house (hos Deapolitalves. III, xt, eto.) In Leti egorite, Los ocntens. Loc dognulees and tos rumpoure it appeare that there 18 wore than one street, or at lesot the 11lusion of more than one street, on-stage. To this extent, the convention oorresponds to Serl10's "comlo scene", where small alleys open off the inain central space.

The number of essential compartiente, even in the later perlod, varies Iron one to four. In Perrin's Los escoliors, visin's house is the only one, and there 18 no reference whatsoever to any other oompartment. At the other extrewe, Les ramonours neads four compartments; and Les Neapolitalnes nods at leest three, probably four or even flve, while in addition four other glacea vistted by 
the oharcoters off-stage in the course of the play are procisely nared.

The compartmente in the comedies, then, are always tom houses 7 th a street or streets in front of them. It 18 perhaps noterorthy that no comedy has any compertment reiresenting anythin other than a toin house. The mémoire de Mahelot, from a later perlod in the hlstory of the theatre, has oorgartments of mory othor kirids (cuves, castlos, cometerles, prisons, grardens, oceans, otc.), not merely in trigedies, tragloomedies and pastorals, but also in ovmedios such as Du hyer's Les vendances de Juresnes. '

The town houses resularly have certain fortures in cominon. arery one has a door opening diractly on to the street, In vipw of the audionoe; in every base without exoeption a character or oharacters go through these doors, and in Los esurits and Les eseclifera ona can be hosrd opening. In Log contens loulse locks ons with a key. Sometimes the door is all that the corgartment requires somet1mes considerably more. Thus, in Lee ooxtans Loulse's house has an upper storey with a visible window that opens and closes, and several others also have upper storeys and windovs. Angélique's house in Les Deapolítalnes appears to have a 'haute gallerlo', but there is nerer a balcony of the gopac and Jullet kind.

1 Le Molre de Moholot, ed. olt., p. 94. 
Any serensäing (Les esbahis, La fidélité nuptisle, Les rawoneurs)

18 done to an upen window.

It $1 \mathrm{~s}$ clear, however, that some cospartments, althoush they may hare a door, oould perfectly well bo mere 'flats' or ourtairs, without an interior whlch oun be acted in. Suoh are Giraxd's house In Les contens (IV, IV) and Angélique's house in Les Neapoll taines whore as I havo sald it causes somo dramatio awkwaraness in both ouses that cheracters are forced to remain outside a house. In other pleys, there is no duch amkrardiness, but nevectholess there is often no evidenoe whether a petioular scano ls taking plaoo inolde a house or in the street outside. Many compartinents thus have no need to be anything other than 'flats' or curtains.

Others certainly have Interlors within which action tokes plaoe. Such are Gulllaure's house, L'Bugène, I, 111, presums.biy the house in Jodelle's lost play La rencontre, Ionsleur's house, Le reoonnue, I, 11, Gande's and the Captein's houses in Les ramonoures and perhaps Grejolre's house, Los desinlsez, III, $\checkmark$ and $\nabla 1$ (the aotion inside loilse's house in Les oontens, though oonsiderable, 18 meroly reported). Ill $31 x$ houses have a door, comunicating with the street, through which characters pass in the course of the play, action taking place both in house and sizeet. It 13 nooesary, therefore, that both the inside of the house and the street should be 
in view of the audiance. There aro two solutions. Pirst, for the earller plive I susgssted the use of a curtain, as in the Terentian 1llustrations suoh a curtain was certainly used a fow yaars later in the liahelot drawings. I Ox 1 t wight bo done by dellberately omittine the wall of a house that is on the audence's side, so that the interior is visible to the audionoes Serlio 11 ustrates this in his trante scene, but not in the comlc scene. ${ }^{2}$ in Les runonapur (IV, $x$ ) (and in Lasphrise's Mourelie travioomiane) an interior door is broken dow, susgesting sowethin of the kind. Some of the Mahelot sets are close to tha sets required for these pleys. For one thin, they are plotures of sets bullt on the IIbtel de Bourjogne stare, where Les ranoneurs for one wis performed, the set for Les ramonourg not being essentially differont from that requirod for the earlier plays. In generil they are more complex; but where it happens that a plas makes similar demands to those of our comedies, the set 1s similar. The closest 18 probably Rotrou's Les Mlensohmas, with four town houses, oach having a door and a vindow above, and with a neutral street area and alleys betwoen the

1 Cf. Le Mémolre de Mrbolot, ed. c1t., pp. 73-4 (Hardy's Le

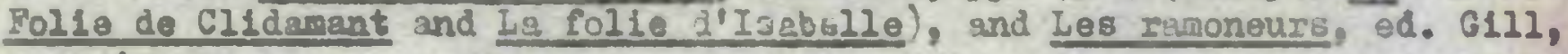
p. xxiz.

2 Roproduced, for example, in Lavrenson, the prench stige, flg. 9. 
houses. ${ }^{1}$

It is, of course, an artifictal convention that places whIch mijht be supposed to be some distanoe apart ars get close to owch other on stags. Potiron in La reconnue, arriflng at llonsleur's hous, from off-st go, 1s 'hors a'huloine' (IV, $\nabla 1)$. But st lewst In the comedles the vurlous houses are all supposed to be within the same town, thus fulfiIIn any theoretloel roquirament for the unity of place, wherges in the trosedies and tragl-comedies of the turn of the century (suoh as chrotion de Crolx' Les porturals infortunis) dist anoes of many miles orn be Lnvolved. In one play, Les contens, the three compartmonts are supposed to be vary noar each other $1 \mathrm{n}$ termo of the plav 1tself (III, 111 and IV, $\nabla$ ), a touch of realism peouline to this play and strictly unneceseary in terase of the convention of door almultans.

A problem presents 1tself in tise cssas of L'Dugene and Ies liespolltaines which may be solved according to the tegree of artifiolality which is assumed. In L' usene, it 1s reported that In the interval between II, 11 and III, 1 hrnault goos to Julliciume's

1 Le llemolre de vahelot, od. olt., 2.89 and drawing. $\mathrm{g} \cdot \mathrm{fg} \cdot 14$.

2 The two compartwents of jos corrivaux aro ol inl larly supposed to be near euch others but the fact has to be deduced and is less obvious than in Les contons. 
house, enters, confronts the oompany present, and doparts. In Ies Heavolitaines it is aimilarly reported that between III, xil1 and IV, 1 Canille enters Angélique's house and sends Cormelle off to do the shopping, Cornellio retums, is delayed by some atucionts, Cai11le leares, Combl1e entexs and then emorges.. Wo leam the 30 things by reports but in both cases the house concermed is a corepertment on stege and in full view of the audienoo. Are we to assume that the audienoe 'forgets' that it has not seen the action? Or that in both cases thore is a break in the performenoe, an interval, perhaps oven with a ourtain drawn? The elaborate dumbshows that would otherwise be receseary can herdly bo considered. 111 this sugsoats a remerisably stablo soenio convention, In which the sanie features reour continually. Throe consicerutions Ina we to think that they rapresent ar actual stage oonvention throustiout the period and not at any time a literafy and hypothetioal one. One is their vory otabilitys the detalls of decor (and, 38 we shall see, of time-sequence) hardily ohange through seventy-flve years, whereas freedom froin the linitations of the stirge in fit haro sucgested varlants whioh we do not in frot find. Seocond, the letalls have had to be sleaned from texts where they are acattered, hapharardly and often anblezouslys if ther wore not prsotion, they might surely be expected to be more yatematic. They occur inclientaliy in the 
plays, usually having a dranatic function so well so fiving mere scenic Information: thus in Les Feapelitalnes, $\nabla$, IV, Marc-iursl adrulring all the colleges is not merely indiosting 'sconory' to a reader, he 18 expressing the astonishment und naivety supposod to be proper to a strunger visiting Parls for the firat tine. Often It is not clear whother a scene 18 supposed to be at cone house or another, 1nside or outside, and the very laok of system, when one oonsiders It together with the consistenoy of the detally that can be gleaned, seems to be a good indioation that the convention we are doaling with is a pristioal and not merely a literal ono. And finally and ore convinoingly, actual produotion sesma to be sujegted by the two pasagea where characters, at the oost of some dramat lo awkwardness, choose to remain outslde a coipgartment rathor then enter 1t. The only reason that presents 1 tself is sconic nocegeity, in that the compartments in questions are were flats or ourtains, and that action ormnot talse plaoe whin thom. Fad tho plays not been written with produotion in mind, the aharioters could quite simply have 'entered' their compartments and continued their conversation.

The cuestion of improrlection was mentioned in comection with the farees. Improvisation by a good actor would, of oourse, at once remove the necessity for many of the pleces of staje set whioh 
wo have been disoussing, and for propertles as well. Tho Jean-iouls Barrault of Ies enfants du paralis Id not nood an actual pocket watch to convey to us the idee of one, and the Itallan actors so closely connected with the Fronch comedy of this time had a suputation for Improvisation as great as any in theatro history. A 'realist' schocl of acting at this t me is bost unlikely, and it wculd ba netve to take literally exch alngle reference to stagins in these lavs. 3ut there is no evidence; and if i play refers to a serenadu sung to a windor abora, 1 t 18 at lesst difficult to do al thout the intor. had above all, the continutty of the references to winicus and the 1ike, and to the nature of the total set, does sugsest thet throughout our porlod acturl staje sets were used.

1. Action on-sterges stylos of natins costumas propertier: masksi gtace-directions.

The point about lmprovisction leads on to the whole guestion of acting and action on-stage. Lost xiolent action, we find, 13 set off-stajo, a standard theoreticel prinolple of course for trazodies up to the ond of the ICth century, and followed in the comedies too. The rlot in Les corrivaux. the escapo throun the

1 hore detalls about aoting w1ll be found in part III, there astdes and solllogules, ani the spoeck proper to oortaln charioters, are 31scussed. 
window in Les contens, and all the seductions, happen off-atage, just iike all the deaths and murders in the trajgedies. If we compste Renaissance farce, we see how little physical action is used in chis comic tradition, where the most violent astions that can be ciced are Camille's hasty exit from a house in Les Neapolitains (III, vi). the tile-throwing in Les esprits (II,iii), and Rodomont's arrest in Les contens (III, ii) - and also, exceptionally, the brasing dom of a door in Les ramoneurs ( $p .127$ ), which may be accounted for by the play's late date or by its known connection with the farce-actors. One action of setting certein action of f-stage is that the woten's parts can be made very small.

Other stage business can be deduced from the text. We have already seen how characters continually go in and out of door. Other action involves the use of properties: for example panthaleone singins to his lute in Les esbahis, or the use of disguise. Character after charucter overhears without being seen: such as Potiron in La reconnue (III, iv), Désiré in Les esprits (II, i1i), or Gregol co and Maudolé in Les desguisez (IV, $v$ ) who specifically move aside for the purpose. In Les contens, characters hide their faces with theis cloaks (III, $v$ i IV, $i$ and iv). The particularly liveiy actions in de Vivre's La fidelité nuptiale were rightly described by La Valiloro in 1768 as lazzi: 
Ascanlo, valot do Charès, est sussi sortí arec un luth, et va chanter dans les rues. Tout oet acte so passe on lazzis [s10] antre oe valet ot une ilgure misquée qui lut falt plusieurs nlchos. ${ }^{1}$

To judge from this knockabout scene, from the bright costupes, from the maks, and from the Italian names in the plny, it does look very muoh as though do Virre has been influenoed by the ouxr.edis Cell'arte, already in the 1570 's, rather more than has ol ther d'Arabolse or Tumèbe.

Thers are three seronades. Panthaleone in (II, 111 and $V, 1$ ) singe lines frorn Orlando furioso to the luto.

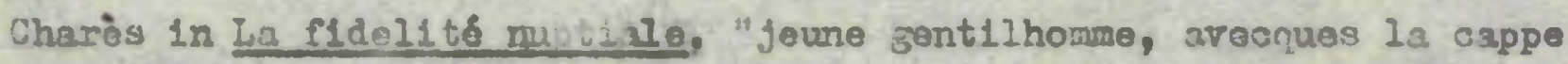
et I'espee", sings parts of no less than fivs of the most poouler chansons of the days Touteg los nulots, Jusanne un four, Io four mon ooeur, Douloe monolre, and Lon ooeur se reoommande a rous; his "Gerson" Asoanio ("ear rous sevoa Messleure Tel Maistre, tol valot") sings parts of D'Anours wo va tout au rebcurs, an entrant on wz 19xdinat, Chancoons propos and cul vout entret on sraco. In Log rrmoneurg, philippes aven hires a consort of volces, lutes and guttars to serenade Diane:s

(Dlani:) Mon Dieu, quello ravlsaante melodie, qquel

1 La Valliòre, Bibliothèue du theâtre rransolo denuts son orifine, vol. I, Dresden, 1768, Pp. 215-7. 
agréable melange do volis, de luts et de Guttarresi. Sisoute in als où ton nom est lingere ....

lioferenoes to ficial anl boulily expregsion ovour, but aro

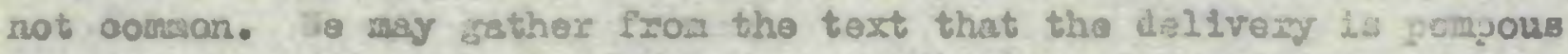

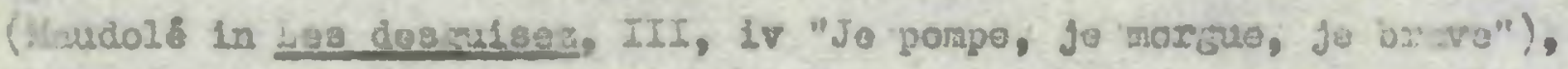
ox ly-10al, or riolunt, but thore in not mah other evicingu about

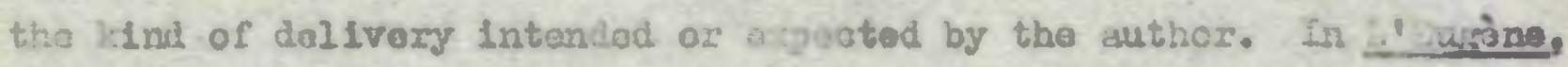
II, il, Morimond Bays to Amault "litu t'en venols tzopisnut / Four me trourer" and "Je te voyols mouvolr 10 doy, / tet marmonner en tos

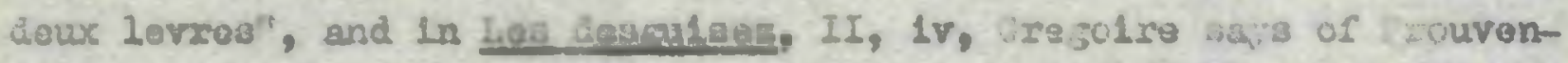
tard "Il g"on Vo furleusenent". Datalls of stage deliverg, aw Lis the succoedinz century, do not appoar to have been purt of the author's

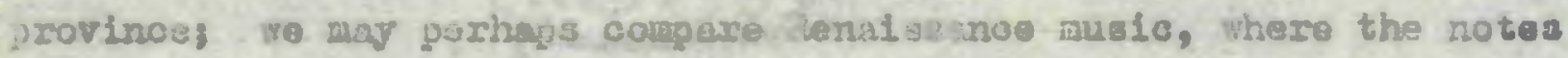
beforo the parforwers oule cortainly be pl yed in may alfforont way and on mosy different instruments, to bo dpolded by the porfoxmers, Ant apecisled by the cangoser.

Costusea are oftim rixial and colourful in the conediess

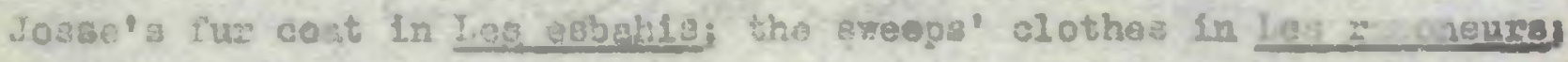

1

Les roporeurs, od. Giml, D. 34. G.f.g. 15.

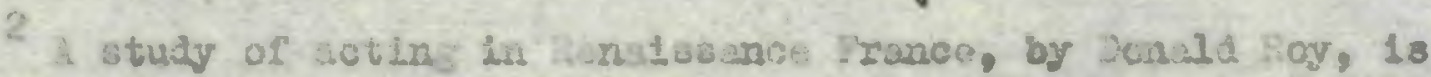

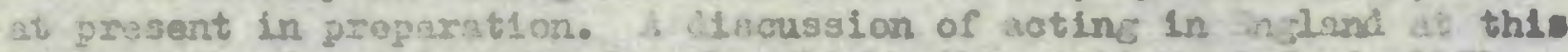
tive may bo found in 3.L. Joseok, Ii gabothan Boting, Oxfork, 2951. 
Dom 'Dleghos' oloak in Les Masuolitainas. Diagutse is comonly part of the plays' comle structures in Ies ramoneurs sweeps' olothos with a Ilttle soot ere used to dissuise a woman as a man, in Les contan Al1x is disgulsed also so a man, ind In Les desgulsez the device is of course funlamental to the play. Costume 18 inore lmportant atill In Les contens, where Túmòbe has wade of a soarlot oloak something more than a stook disulse. It and a second clook excaotly like it are intograted Into the plot, and are essential to no less than six different scenes of the jlay, worn by four different ohsracters. The scarlet colour, as Ix. Speotor paints out, is an 1ronlo cormont on the eupposed virtue of Geneviefve, to whlch the oloaks are al zaye related. I Gexard de Vivro, too, though he says in the jrefroe lux lecteums to his colleotion of plays that comedies deal with "matlere vul falre" and therefore do not require elaborate costunes, nevertholesa uses several costumes to some meaning in La fldellte nuptlale, such as a blick dress gignifying melancis $y$ and mouming, or the white sleeres of Palestre signifyins wifely virtue.

Ilo ferences to other 'scenery' or to 'properties' other than clothing are not frequent. In Los esbahls, La flaellté nupt1ale and Les ramoneurs we have the lutes and oultars noeded for the serenales.

\footnotetext{
1 Les oontens, ed. Spootor, Introduction, pp. xIv1-v11, 2xT1-1x.
} 
In La reconnue thare is kitchen equipwent, in Les eaprits tiles and a purse and a 'trou' to hide the purse in, in Los ocontens and 'auvent' andior a oart, in Las dessuleez a puree. A plece of 'sconery' or more comp artments or 'flats' la Implled Ln Les Nospolitaines, V, 1V8 "Toutes cos grandes malsons, sont-ce colléges?". Les ramoneurs is unique in needine quite a collection of sall 'props'. A good use of them is found in Les corrivaux, III, ili, where the two servants Allzon and Claude find themselves in tha otreet ombarressed by the distarf und terch then they aro respectively carryling and whloh each Intends to wave as a secret sismal to the lover who h:s bribed him for the purpose,

The Italian actors, es re see tham in the plotures of Itelian comedy in Frunoe, wore masks for some oharacters but not for otherg, that 18, for any givan play we are to assume the rather odd theatrical technlque wheroby aome actors woar them while othurs do not. The French farco-actors outalnly used them, the teohnicue

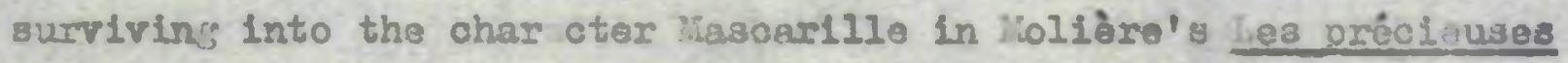
ridioules, ${ }^{1}$ while masks vere among the equipment of Valleran 10 Conte in $1598 .^{2}$ In our plara, though actors may well have uied thon, only

IThe Testoment de feu Gnulter-Garcullle refers to thos hablt noli, non rasque, miz chevelure blanche"s cf. D. Loy, Conditions and

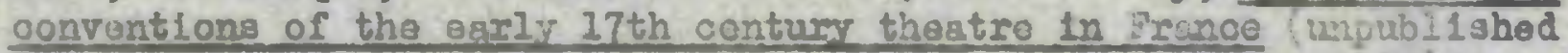

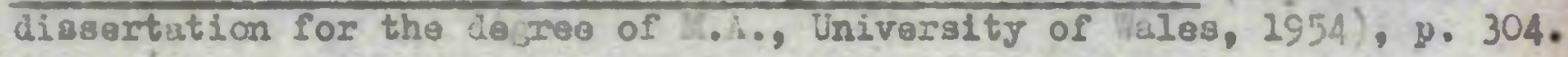
2 D. Hoy, ibid. 
one pley spectrles a mesk, and that orly for one cherseter: de Vivre's las fldolité nuotiale. A stroge direotion, at the point where tocanio is singing hls flrst sone (D' Amoure me ve tout au rebours), roads: "Copendent qu'Il [Asconlo] ohantera, sortixa un sutro accoustré legierement asant un mesque devent la face." In Addition, In the last scene of Les levoolitialnes, Gester the porasite tuxns to the audionoe for the flnal speech of the play which includes the trords: "an nez, tel que vous le royez, squt blen à quoy s'om tenir: qui bien fera bien trouvera", which may possibly refer to a mask.

As for strge direotions, they are found in uantity only in one source, onco ajain the plays of cerard de rivro, which seom to have much to tell us about the fenaisance stage. Lrory edition of de Vivre's plays incluces a list of slgons which are liberally used in tho ploys themselvos:

La simifioation des slgnes, desquels f'useray en toutos mes comedies.

(x) Ce sizme, sionifile une pause.

(x) Cestuy Alux.

$(x \times)$ Cestuy trols, chasoune pause yaut une roprise d'haleine.

d) In pourmenement par tout le Theatro.

( ) Cocy simirio parler bas. 
"Cecy slemifia, de porler plus vite que le reste.

- Ceey de parler plus lentement que le reste.

In adition to these sifns, de Tivre's plays al so contain staye directions istren in full, such as the one quoted above for its mention of a masis. Occestonal stage oiroctions are found in the other plays, but they are rere end lsolated, like thio from Leg espritg: "Il ergche, et coux de daduns jettent des tullos" (II, 111). The woris "ingh tach tooh" are curiously put Into the wouth of cheracters in Larivoy's, Turmàbe's and d'Ambolse's plays to Indioate that they are knocktng at a door. They may therafore be classed as a staje direction.'

But detalls of acting technique and of stape conditions at this time are unlikely to be peculiar to the genre of comedy; sc that these deta1ls, Gisaned from the taxt of French fonalisance cumedies, cen be soen to bo relevint to the french kenaissance as a whole, about whlch we have such scanty evidence today.

1.

Oxuzic Vocchi's 1 'tafi mage, Venice, 1597, which be not quite the flrat opera $1 \mathrm{~s}$ \& play aun; in madrigat fom, most oxtram crdinarily getg the works "ich tech toch" to ausic, is thouph thay Hert Indeed spoken by the charncter conoerned and not merely representin the sound of his lonocking. 
1. Comio theory In the Mrench Ronatasanoe.

Drumatic criticism in Renaissance Brance is at first of jht small in quantity. There is no parallel to Comeille's Discoure, for example, nor to the ample prologues and epleties which Ben Jonson added to his pleys. We have todey three souroes for Frenoh Renisannos dramatic theorles: the treatises on poetry in generel, the liminury material to sctual comedies, and (for comedy) the oomentaries on Terenoe. The flrst of these fires drama a small plsce indeed; the secund is frngrentary; and the thixd prinarily pedroglo, oven podantio. At first sicht, this is perhajs surprisin;, to us for whom the dramatic procuction of the lonalssance is one of its principal legucies. But in Frunce, for various social, political and economic reasons, arama never achieved the flowering thet it did for exazgle in Inglend: in the inst decade of the 16th cantury, when aristocratio patronace and popular support combined in England to encourage a ramidly inoreasins dr natic activity, Pranoe was in the srip of a far sadier political situation, and the inglish fusion of clasicic influences, of the experience of the Italian actors, and the nat1ve drama, was never achievel there. 
Sut all the same, the dearth of thecretical materlal 18 partly an 11lusion. The extracts from treat1ses, ani the Iininary i..aterial to plays, may seom frementary indeed, but the apperranoe 18 deceptive, for two reasons. iretly, drama in general was not, In the 16th century, consicied as anything other than as a spocles of poetry, alon; vith the ode, the hym, the eplc and other forms. Scaliger, pratoing the conto form, pra1ses it opociflcally in Its context is such a species: comady is the rixst and trae form of poetry In goneral, beonuse of the speoial role of invention in it: Tantum enim abest, ut Comoedia ooma non sits ut pene ormium et primun, et verum existinem. In eo enin rlota ormi:, ot matoria quasita tote.1

Jpecifloally aramatic oriticlsm as such was less possiblo then that it 18 today, when theorles of the drama - as of the novel or of lyric poetry - are often readily disoussod in 1eolation. It follows that mary ideas which are cortainly relevant to Renatsu nco views on drama are to bo found expressed as relevant to pootry in general. It is essential to keop this broader viow in mind. here the author of a treitise mrites a section on tragedy or cumady (or on the evic, the hym or the ode), he will put in it only auch ideas sa are supplementary to ideas in loh he bas expressed as relevant to poetry in senarals laas on imitation, invontion, decorrm and the

\section{1} Joetloes libri septen, Ioldelber:, 1607 edn., I, 2. 
like. We must therefore take full notioe of those more wiliely applioable 1deas. - nil secondly, one form of oomic theory was Inescapably part of evory oultiv ted man's oduration during the Renissance: Terence's plays and the ooumentaries on thom, both those ascribed to Donatus and those by more recent critics. Marvin T. Herriok has discussed the influenos of the compentaries in s Luropean context, ${ }^{2}$ while H. . Laton has shom particularily how Groat was the number of editions of Terance published in Funoe at this tino. 2

All the sources of colnic theory in firance are normally descriptive, usually of Ierentien or of contemporary French protice. They are less often prescriptive, even though thoy may ostensibly apperr so, or historical in any dischronistic sense. Then Jauwuin de la ireanaye in 1605 prescribes rules for the observince of liscorum of specch in comody:

Grand' difference $y$ a frire un maistre parler, Ou Davus qui ne dolt su malstre g'ézaller, ou lo bon Pantelon, ou Zany lont Ganasse

1

Marvin T. Herrick, Conic Ihoory in the Sixtegnth Cantury (IIlinols Studies in Lan uive and Iterature, 34, nos. 1-2), Urbane, 1950, published separately, Urbena, 1964.

2 1926. 11.. Lawton, Téxcuce on Brance au XVIo Bibele, Puris, 
Nous a representé la fragon et la srace ${ }^{1}$

he is cortainly referring to the ndria of Terence and to plase performed in sance by the Itallian troupe of ansasa. ${ }^{2}$ His presoriptive or didactio form is, as so often, with Renaissance instruction books, in fret a oloals for description, in this crse of erence and the cowsedia dell'exte. Then a genulnely presoriptivo approach is in faot adoyted, it is usually in soneral terns, not in terms of detailed drinatio prsctice; thas Du Beilays

quanti enx comedies et tr jedies, si les roys ct les republiques les vouloint restituer on leur ancienne dignité, qu'ont usurpée los farces et moraliter, je seroy' bian d'opinion que tu t'y e:ployasses, et si tu le veux falre pour l'ornement de te Lanjue, tu scals ou tu en dolbs trouver 103 arohetypes. 3

The dramatic thoory that is to be found in fenelasance treatises on poetry - those of Sebillet, Du Bellay, Peletier Au Nens, Sorliger, Pierre de Laudun. d'Aljuliers, Vauguelin de la Fresnaye -

1 Jean Vauquelin de la Presnaye, I'Art Doet1que, I, 1605; quoted frow H.W. Lawton, Landbook of Rrenoh Renalssance drumaile theory, Manahoster, 1949, p. 104 .

2 On Ganassa, of. A. Baschet, Les co: édiens Italiens ì 1. cour de rance, Paris, 1302, chapter 1 .

3 Ls Deffence et Illustr tion de la Lanme rensorse Paris, 1549, II, ivi od. 11. Chomind, Paris, 1901, p1. 125-6. 
and most of the relevant liminary material, have been valuably gathered together by H. . . Lawton in his Handbook of Nrench Renaisgance dramatio theory (Hanchester, 1949), whioh will be frequently referred to in the pages that follow. The material is nocessarily 18olated; In the case of the theory, from the rest of the treatise, and in the case of the lininary material, from the plays that accompany 1 t. W.F. Patterson's Three centurios of French poetio theorr (Ann Arbor, 1935) amplifies the context in the first csoe, while the examination of the plays themselves in the present work should give the oontext of the second. A brief survey of the sources that survive, their stutements on comedy, and the context of those statements, is as follows.

ile may be gin with the period just before the Plélade. Earlier than that, conlc theory wes certalnly dlscussed, but primurily in connection with the plays of Terence and the commentaries on them, and the ideas vere broadly ldentical with those of Donatus and his suocessors. And as far as comle practice is concerned, our material begins at the mal-centurys the literal translations of the earller period, and the other conres such as the plays of Marguerite de Navarre, do not conoerm us here. Ith these theoretioal ideas in mind, it should be possible in the succesding chapters to approsoh the dramatic prootioe of the time and in particular the use that is made of dramitic conventions directed towards audiences with certain 
lnown tastos and 1iterisy trainin?.

The firat full-lenth trestise relevant to ocmedy is Thomas Sebillet's lut Pootiuue Pransois (Lyon, 1548). Its author's interest in drame 18 show by his translation into Frenoh of "Luripides' Iohiven1a. It preoedes Jodelle's I' Lurene by some four yeari, and by 1ts dato uready has a partioular intarest, bocuse of the somewhat embarrassed position in whlch the Pleiade as a Jroup found thomselves towards its author'a ideas. Herrt Chamrd has shown how dootrines which the plelade would have liked to groolain resoundingly as now and their own had already been expresged, arkarardy for them, by jebillet. ${ }^{l}$ ts far as comedy is concomad, it tums out that the situation is complex. Seblllet's esction on the tinoatre 1s primarlig desoriptive, cccepting the medievil genres as they still activoly survived in his own dey. He is concemed with questions of terminology: Farces, Lotties, Comodies Latines, Comadies

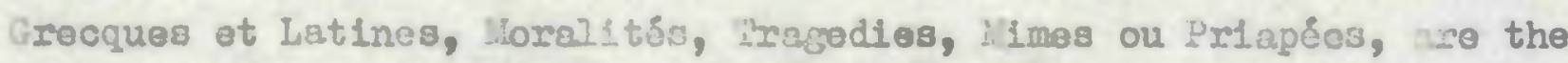
ter 9 whose relationships and ilfferonces ho discussca in two chort para,rophs. Larller, he has discussed morilit1es nd foroos, accepting them (despite his disapproval of the incecancy of the furces) as part of the stato of the theatre in his time, and indeed ivins

1 Chanard, I1stolre de Ia plélade, I, 160-3 and 192-215. 
certain maxims and instructions for miting them. -- His comantary on them 1s, then, deccriptive ("nouc no falsans aujourd'juy ne pures

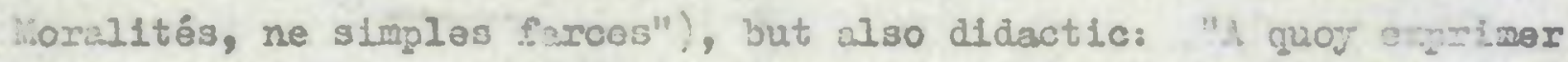
[frrces] tu no doutes polnt que les vers de hult eyllabas ne solant plus plaisans, et la ryme platte plus coulante." It Is stranje, to sav the least, that he does no' disouss farentian comedy desyito the several comentaries on, truslations of, and aiscuscions of Ierence which had appeared beforo his timo, nor Itallan coiady Les ite the famous court pericran nce of the Calandrle at Iyon in 1548 and despite Estienno's tranolation of GI'Inoganeti into Fenoh In 1543; he is concemed with the oontemporary medievil survivals only. From the more forvard-looking ldeas found in the rast of the

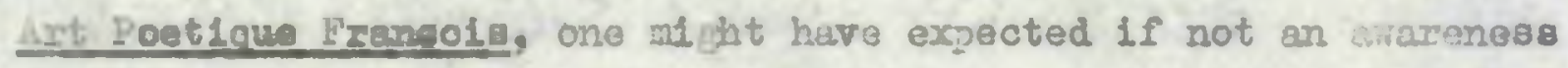
of Italian theatro, at least moro interest in Terence. Du Bellay, us one tieht expect, rejects this vier, For him, the classical theatre is alone rorthy of imitation. But the short paragraph in whiah he expresses this view (dicid ahovo) is a bongre statement Inded in a treatise supposed to prepare the ray for a new national literature. Not only are the Italian comodies not mentionod in the Deffonce ot Illustration (which in the field of lycio poetry strongly and of course succossfully advocates an on other things the imitation of Italian models), but evan the name of feronos, 
the obvious model, does not appear.

The question of inftation of ancient comedies, of abandonrent or preservation of medieval forms, which has so far been answored only with lack of perception on Seb1llet's part and lack of attention on Du Bellay'8, takes a more interesting turn with the theory anl practice of stienne Jodelle. It 18, as one would expoct, totally opposed to sebillet's. Jodelle does not acoept the status quos for him, moralities and farces are part of the medievalism which is to be refected in farour of antiquity. They are impatlently disisisedi

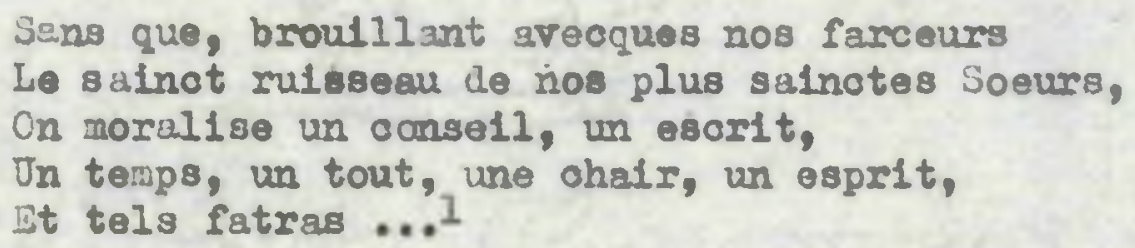

But a disorepancy olearly exists between Jodelle's theory and his practice. In theory, farces cause an unwelcome muddying of "le sainot rulsseau de nos plus sainotes Soeurs"; in fact, L'Wurène ores wuch to farce techntque and conventions. ${ }^{2}$ So that wheress in the fleld of serlous drama, Jocielle's olaims to have broken with the modieval genres

1 Etlenne Jodelle, i'Jugène, ed. J.F. Balmas, Lillan, 1955, prologue, 11. 37-41.

2 Cf. part I above. 
In favour of a olessloal ane (Seneoan tragedy) were fully justifled, in the field of comedy his similar claims were not substantiated. The next treatiso is Jacques Peletier du Mans'. Ant Poetlque, Lyon, 1555. Here arain, as one would expeot of a member of the Plalade witing a theoretioal work, modieval genres are dismisseds

Nous esperons qué les Furodis qu'on nous à 81 lon; tans Jouepo of conuertiront an $g^{\prime}$ anro do la oomedís: les Ieus des Martiróp, an Is formó dó Tragedíbs I

What 18 perhaps more surprising is that creation of comedy in France is expressed as a plous hope and not as something which has alresdy been begun, according to Peletier, the Frenoh oomio theatro st1ll consists of worthles: medieval genress

nous $n^{\prime}$ auons point ancorós vì an notró Frangoes aucuns Ecriz, qui ussét la vré formé Comiquós mọs bien forcé Moralitez, e telés sortés dé jeuz. Auquez 16 nom dé Comedí n'st pas di. 2

In fact, Jodelle's i'3ukve dates from some throe yoars before this treatise; did feletier simply not know of it? It may well bo so, for he admits that he knows the cleopatre oniy at second hand ("und [tragedie] par Stlend Iodeló Parisien, dó laqueló f'è oul seulómant 16 brult"). ${ }^{3}$ or could it be that the fareical elements in the play

I Art Poëtlque. II, $v_{;}$ad. A. Boulanjer, Paris, 1930, p. 172.

2 Ib1d., II, vil, p. 139.

3 Ib1d., pp. 192-3. 
made it unworthy, for Peletler, of the name of comedy? In any case, with the exolusion of modieval senres and the omission of Jodelle, it is olear that what peletier has to 8 as about comedy will desoribe clasical proctice, and not prestice in Frenoe in his orm time.

Peletier's discussion of conedy la the longest that had as yet been writton in France. Fo discusses in succossion comedy as a mliror of lifo which shows us certain types of peoples plot-Btructures the merits and demerits of Terenoe, Plautus and others 3 the desirability of comedy in France; the differences between comedy and trajedy (rank of characters, endins, eloments of the plot, diction). Hls starting point is Cloero's description of comedy as "imitationem vitae, speculum consuetudinis, imaginem verltatis"; his analysis is from Aristotle and Donatus; and his model is Terenoe. It may bo worth discussing these points.

The Cloeronian desoription was known only through Donatus' De trezoedia et oomoodie. But it was widely knom and continually quoted we shall find it again, for oxample, in Larivey's dedication of his 1579 colleotion: "La Comedie, vray mirouer de noz cuvres". For these men, it is of course only a statement in partiouiar terras of the lienalssunoe principle of imitatio: art is not somethin created anew, something "orisinal"s but an Imitation, elther of naturo, direotly, or of naturo through 
other (generally classical) writers. The 1dea 1s Platonic, and may have been famillar to Donstus, as well as to his Renalssance succersors. Thus comedy, like all other forms of art, is a recreation, a mirror to life. For Peletier, the things it reflecte ara:

l'auartop ou 13 pruilanop des vielhana: 138 anours e ardeurs des jounés anfans dy mpsons les astuó́s e ruspés dé leurs Amiéss la vilénifo deshonnetéte des haquáreaus: la façon des Feróns tantót seuerôs, tantót faollós: l'assantaoion e vilóte des parasites: la vantórí o brapple d'un Soudart rótire do la sugrrós la dillg'anoṕ des Nourricés: I'Indulg'ancó des Merpisl

that 18, the chareoteristics of niddle-olass people and their servants and hencers-on, seleoted according to Terentien models, as opposed to the kincs and nobles of tragody.

Donatus, and not "les Greos", propldes the terninology for Peletier's disoussior of plot-structures prologue, protasis, opitasis, oatastrophe. They are the standeri terms used in that falliar oommentary, and I shall disouss them further in the section on plot-struoture below.

Peletier's discussion of oomedy and of the differenocs between tragedy and comedy is in Arstotelian terms, of plot,

1 Art Boötlaue, II, Vi1s ed. cit., pp. 186-7. 
character and speech. About sppeoh or diction, he sav that "La Comodio parlo facllomant et ... popuiorómant", ${ }^{1}$ and refers to Cireilius, clled by Cicero a "mauues auteur dé Latinite". 2 These Arlstotelian diviaions are readily though waltly aooepted here, Q.3 in wost of the subsequent theoretical writings on comedy. Their Inning is not yet over: the three next chapters in this book are besed on the same division.

Poletier proclatms the excellence of Terence. Theorist after theorist ill later do the same thine and the popularity of that euthor has been olearly shown by Professor Lawton in his Térence on irance gu XVIe slècle. It should only be reatembered here, first that this popularity was not asclusively based an dramatio merlt in Terences and second that Terence is not the only model for the aotual oumedles (as opposed to theorles of comedy) that were written in France bofore Cornellle. is for the reasons for the popularity, Profeseor Herriok has sugseated that the datin one may have been quite simply the existence of Donatus' axcellent camentary. ${ }^{3}$ Also, Arlstophanos miay have been better in many ways,

1

Ibld., p. 290.

2

Ib1d., p. 189.

3

Herrick, Comic theory, p. 5. 
but ho was too irmoral for schols; Blautus too may have been better, but his Latin is not as andrable as Terence's and therefore, sain, not so suftable for teeching in sohools. Scallger says that he prefers Plautus as a comle writer, lerence as a styl1st. ${ }^{1}$ These pelant's rowans may not be the whole story, for Terence's plays st1ll hold the statge today, but they are Important.

liost of Peletier's 1deas reappear, treated at greater lonsth, in J.C. Scallger's poetices Iibri septem, first published at Lyon in 1561. The subjeots trested ares the definition of comedys peril in comedjs the differenoes between trejedy and comedy in terms of plot-elewents, charseter and dictions plotstructure, at some lensths e discussion of the merits and demerits of Terence. We have the Cloeronian statement, slightly chanod ("Cacterum, vel ex authoribus, vel 1psius vitao nostrso exemplis sib1 quisque quantum volet sumet") s the Jonatian analysis of structure, with ahanges by Soaliger, wile the whole basis of the analysis is Aristotelian and Terence is the model, with occssionel referenos to plautus. The discussion is a very full one, and based

1

"Nain equidem Plautun ut Comioum, Perentium ut loçuutorem admirabor" (Pootloes 11bri geptem, Hoidelberg, 1607 adn., VI, 11, p. 707 . 
on firm knowledge of his modols. His inost individual contribution is the addition of a fourth division, catastasis, to Donatus' three which are pzotasis, epitasis und catastropho: this I shall Ieexamine in the next chapter.

After Soallier, the seme ideas reappear. Jaoques Crórin quotes his Clcers on dorrody: "Cloéron l'appello Luitation de vie, ulrouer des ooustumes, et imaje de vérité" beforo entering into 3 history of the genre from earliest times. I It is quite olear that there was a solid body of critical stataments which was well known to all and could be assumed as baslo knowledgo in any audience. In a sense, then, this body of knowledge forma a convention, a frumowork upon which variations oan be built. In 1577 Gerard de Vivro wrotes

Amis Lectours, chasoun squit desja bien que c'est que le Comedie, pouxtant be m'amuseray à la rous desohlffrer en oo liou ol, ì curas, qu'11 y en a tant d'autres qui en ont faict mention.2

Plerre de Laudun d'Alzaliers' Art Poëtique Prancols, aris, 1579, contains similur ides, crouped under subjeot-matter,

1 Brlef discours pour l'intellisenoe de ce théatre, Théâtre cumplet, ed. L. Pinvort, Feris, 1922, p. 7.

\footnotetext{
2 Com die dee amomrs de Thosoue et Diantre, Paris, 1577, prefuoe Aux Lecteurs.
} 
type of characters, plot-structure, diction. He says, Interestingly, that comedy and farce are not roally very different from each other by their contont: only that farees are shorter and do not have acts, and min not introduce goes or gocilesses or charaters frore norellties (comedies of course many not introluce them either - but de Leudun has now turned to the most general definition of "oomedia"). ${ }^{1}$ Jean Vauquelin de la Fresnave, in his full but diffreo Art potiaue, Paris, 1605, uses blrilin idass he adds to them some evilont lonowledge of the Itallan sotoris in Franoe, as we saw, and of both Grévin's and Belleau's work. It is interesting to find this literary theorist insiatin; that rules are not important compared with following the model of naturo. Iven a fareo, if it does that, is better than a comedy:

quelquefolo une farce au vray Patelinée, Où par art on ne rolt nulie rime ordonnée... Pour oe qu' au vray las moeurs y sont representées, Le日 personnes rendra beaucoup plus contentés, Et les amusera plustost cont mile fols Que des vers sans plaisir rangez dessous les lois, N'ayant auce ni suc, ni rendant exprimé La Nsture on ses mocurs de chroun blen almée, Nature ost le patron sur qui so dolt former Ce qu'on veut pour lons tamps en co monde enlmer. ${ }^{2}$

To these treatises mast be added the soattered liminary miterial:

1 Goted from Lartom, Hiandbook, 2. 92.

2 Ibld., p. 112. 
Larivey's dedication to Prangois d'Anbolse, where ho defends his use of prose on the erounl's that orilnary people do not speak in verse; or Frunçois d'Anbolse's grologue in which he olaims that his play 1s, by exception, not based on an Invented sotion, but on a true story or Godari's morslising on his combiring a tragedy and a comedy into a sinjlo unit. ${ }^{2}$ D'Amboise evan applies the theory to his own play, telling us prectsely which part is tho protasis, which the epitasis, and which the catastrophe. 2

To have not yet cansidered the ethical view of canedy. S1f Philip Sidney, in his Defence of Poetry, expresses such s views

Comedy is an imitation of the oomion errors of Iife, which he the comic writer] represents in the most ridiculous and scomful sort that may be; so that it 18 imuossible that any beholder can be content to be such a one. How, as in

\footnotetext{
1 Ancien théstre franeadi, V, pp. 2-3; ibid., VII, pp. 241-2; Lawton, Handbook, 2. 90 .

2 Les Noapolitainss, Paris, 1584, ff. 4-13 "Sommaire de ceste histolre Contque". "He "So:malre" ls not reprinted in inclen thestre franeals, VII, or in Foumler's Le thốtro frangois. Irroughout the period, the editiuns of Terence, with comentaries, continued to appear. In the yoar that 'Lunane was written, 1552, for instance, appeared the monster edition at Paris, containing besides Terenoe's plays rriting and oumentarles by elghteen oritios. It would cortainly be of value to exanine in datall the com ntaries that may have boen lnom to, and ured by, the French Renaiasence writers of comedy. Phis I have not done in full detail, airing rather at an exaination of the pleys themselves, with the context of Donatus' coimentarles (oertainly the best lnow of thes) and of Erenah Nenaiseance theorists.
} 
Georetry, the oblique mast be fonom as well as the right, and in Arlthmetiok the odd as well as the even, 80 in the actions of our Ilfe who seeth not the filthiness of evil wanteth a srest foll to peroeive the beauty of virtue.t

In France, as throughout Europe in the Rensissance, this ethical point was discussed as well as the aesthetic ono. De Virre writes at some length about the moral function of his plays, which are Intonded to show the "variables accidents de fortune". Larivey too develops the Ciceronian image of the mirror to show his pleys' moral function:

Toutes fols, considerant que la Comedie, vral miroüer do noz ceuvres, n'est qu'une morale fllosofle, donnant lumière à tout o honneste diselpline, et per consequent à toute vertu, ainsl que le tesizol gne indronique, gul premier I's faict reolr aux Latins, f'en ay voulu jetter ces pramiers fondamens, ou j'oy mis, camme on bloc, divers enselignements fort profitables, blsigment les vitieuses actions et louant les honnestes, affin de falre oognolatre oomblen le mel est à eviter, et arec quel courgge et aflection lo vertu dolbt estre viorassée, pour meriter louanci, acquerir bonneur en ceste vie et esperer non seulement una gloire sntre les hommes, mals une oeleste recompense après le trespas.2

1 cuoted from M.C. Bradbrook, The prowth and structure of Blizabothan comedi, London, 1955, p. 29.

2 Eplotre to Frangols d'Arbolse to his 1579 collections Anoien the 3 tre francals. $7, \mathrm{pp} .1-2$. 
How far did this vien turn out to be an excusa for imriorality, und how far was it real?

Worility is not important in the Plelade comedies. Though those plays were bom in a University milleu, they wore not Intended to have pedarofic value. The differenoe is important; at the Colleste de Boncourt, comedias were written only by stulents: when teachers such as Muret and Buchanan wrote drama, they wiote edifying trajedies. Jolelle's aims were to make his own reputation, and to aohleve an sesthetically successful exumple of the new classical genre in French, but not to teach anything. In fact, L'Sujène is Immoral both in Ito action and in Its outcomes NILx at the end of the play pramises fidelity not to her husbend but to her lover the churchman Bucèno. La tresortère is about at tempted adultery, once sucoessful end onge unsuccessful, and about unscrusulous finencial dealings: no work of condemnation of these thing is uttered. Les oontens plays ironically with the gap betwoen real Imnorilty and the bourgeols concem for appearances: the ircry is sesthetically successful, but han no reformin; intent. Host of the other plays end with a maxriage after a successful, and often forclble, seduction. "Ihay say the comedies rather tozoh than reprehend anorous concelts", wrote Sidney - and so indeed it appoars. ${ }^{1}$

1 Braubrook, Blizabothen comedr. p. 30. Cr. Des Autelz' ... 
Les ramoneurs in the asrly $1620^{\prime} \mathrm{s}$, with its prostitutes and prom curesses, is thoroughly in the sate tradition. But islite, some five years later, represents the and of this kind of Renulesance comedy, for in it not only does formollle take as ils abject poople's affections only, but he spocifically oondems infldelity. In practice, then, Ranaiss nce comody seems to huve wimed at dellont rathar than mor 1 reform. Ferheps the injishman Iyly had the most honost abtitude whon he wrote that his plays voro made for pleasure, were "mere pastime or plajs of the imajination". He irites, too, thrt they were made "to move inward delight ... to breed soft siling, not loud laughing". I Lauphter is not an 1mportunt aim of the iranch plavrighte either, whether in theory or practices wo laujh at the predicaments in i' u dène or Les corrivaux, at the puns, at the bragsarts, but these are all iloments

... similar statement woout comedy (though not about nstive Prench comedy, which did not exist whon ho wrote): "Or que la ioralits ... soit plus profitable que ny 1. Comedie, ny la lregedie, 11 en appert, pource que ces deux tendent plus à la oorruption que à la bonne information des moours: I'une groposant tout exemple de lasclvité, I'autre de cruauté et tyrannie" (Bepl1que ... aux nuxleuses deferses de Louls bialiset, Ijon, 1551; cucted from largaret L.H. Ioume, Gull1aumo Dos Autelz, Geneva, 1961, p. 46).

1

Irologre to the iomen in the hoor (1597), Endicton (1579), and Sepho and Phoo (1582?). uoted from J.H.H. Atkins, nilioh itorax criticism The Renescenos, London, 1947, p. 240. 
inoidental to the principal aim, which is delight.

To sum up: the comic theory follows a constant

pattern throughout our period. Also, it appears in many different sources, pedagogic, theoretical and theatrical; so that a majority of any cultivated audience must have been aware of 1 . Variations on it must have been recognised, such as, for plot, Belleau's unusual delaying of his action to a sudden quickening in act $V$; for charscter, the variety of servants and masters; and for speech, the interplay of kinds of language proper to captains, valets, heroines, and the rest. The reft of this book is about those variations.

\section{Plot.}

Comedy_as one part_of a performance

The Greek ideal of an overall dramatic performance, conslsting of tragedies, comedies, and satyr-plays or mimes, all on a single occasion, oould hardly fail to appeal to the Pléiade, anxious as they were to revive the practice of the ancients in every way possible. They revived Greek practice, for example, in the famous cerenony of the "bouc" which they connected with the supposed etymology of "tragoedia" as "joat-song". But despite their ip-service to Athens, it was Rome that zave them their principal models (Seneca for tragedy and Terence for comedy), and in Rome, as 
far as the survivin evidence shows, suoh overall dranatio performances were not the zeneral practice. ${ }^{1}$ On these grounde alone, then, it $1 \mathrm{~s}$ hardly surprising that the Plelade and their suocessors only rarely achleved such performanoes.

Jodelle and Grévin are tho first to have done so.

The famous productions at the Hottel de Reims and the Collèse de Bonoourt consisted of cleopatre and L'Eugine together, and thelr author was regularly praised for his introduction of both genres into iranoe. ${ }^{2}$ Grévin went a step further than Jodelle in includin: the equivalent of a third dramatic genre of the anolents, the satyr-plays

Ceste cornédie [Les esbahls] fut rafse on jou au collèbo de Beaurals, à Paris, le XVIIe jour de févrler LI.D.LX. après la tragédie de J. César et les Jeux satyriques, appelez somannément les Veanx. 3

1

the first known Latin dramatist, Livius Andronicus, produced a trejedy and a cohedy at the Ludi flomani of 239 B.C., acoording to Cassiodorus (v. Beare, The Roman stare, London, 1955, p. 17). But Beare and other sources otherwise have little to say about suoh com binations.

2

For example in the letter of Denjs Lambin cited by M. Balmas, In his edition of I' Jupène, p. 10. "Delectavit me in primis epiatols ture loous de oomoedils et trajoedi1s Gall1ois. Libenter enim audio linguam nostram, quam ceterse nationes burbaran et inopen esse dlount, antiquarum poetarum venores et omamenta capere, interpretari et exprimere posse."

3 inoted from J. Grévin, Theftre complet, ed. L. pinvert, Par18, 1922, p. 355. 
The satyr-play Les Veaux seems to have been performed also two years earlier, accompanyin Grévin's other comedy La tresorièr, but this time without a trazedy.

Ceste coméde [La tresorière] nt ... mise on jou à paris au collegge de Bezurais, après la satyre qu' on appelle commément les Veaur, le v. de fóvrier M.D.LVIII.1

Los Veaux may possibly have been an imitation of an ancient genre, perhaps aven of luripides' Cyclops, the one surviving satyr-play, but in view of Grofin's own remark that the farces of his ow time are descended from one of these genres, the mime, it wes quite likely simply a farce ("Les anoiens aroyent encores une autre eorte de Comédie qu'1ls appeloyent Mirus ou Bastelerie, pour autant qu'elle estolt falote de parollss ordes ot v1llaines, et de matières asgez deshonnestes ... De là sont venues les farces des Prangois, comme nous pouvons facllement volr"). ${ }^{2}$ Grévin claimed, as we saw in chapter I, that his plays were the first French plays on ancient models (perhaps beceuge he publishod his plays, which Jodelle at

1 Ib1d., pp. 353-4.

2 Brief discours pour I'Intellizence de oe théstre, Théâtre oomplot, p. 8. 
this time had not), and 80 for him the question of an authentio performanee might have been all the more important.

Even with this early generation of enthusiasts for antiquity, however, other influences may have come to bcar. A "farce", we know, was orfiglnally somethin used to stuff ("farclr") a performance of another kind of play, and still in the 16th century was used in this way in the ingtery plays. " Grévin himself writes that he lenows two other kinds of theatre where this sort of programe-buildinc took places the perambulating theatre of the Iow Countries, and the stages of the University of Paris itself:

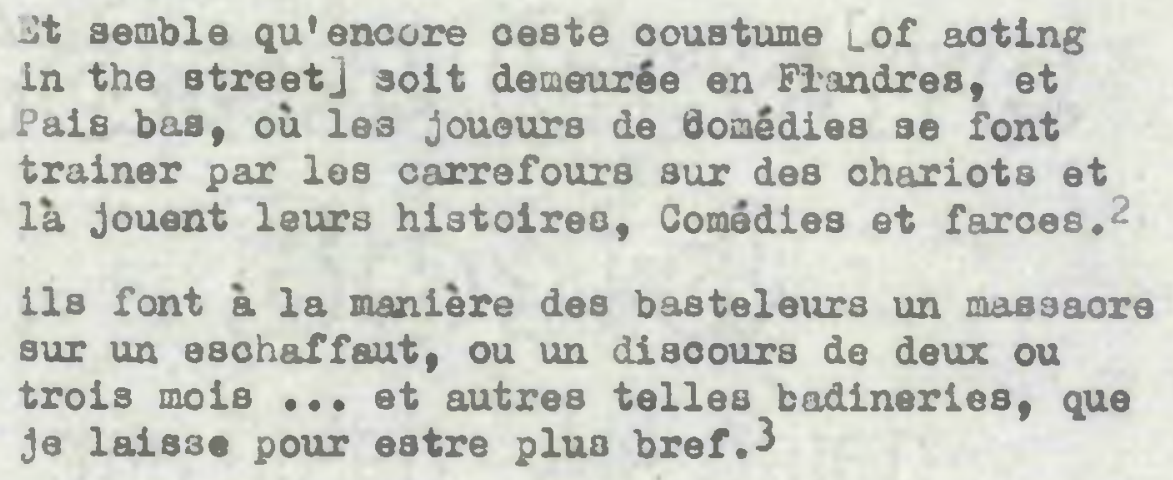

This is an obvhous kind of progranme-building in all agea, perfectly

1 cf. Grace Frank, The medioval French drama, Oxford, 1954, pp. 245-6.

${ }^{2}$ J. Grérin, Thétre complet, od. cit., p. 8.

3 Ibld., p. 10. 
normal to Boswell for example ("At nicht I was with Lady Crawford at The Bezgar's Opere ... The farce was The Pintnor Trlokec"; "The play wa False Jellcacy, and the farce, A Eeep behind the durtain"), though in the professional theatre of our own day it is perhaps less frequent. Furthermore, as Grevin says, the question of the personal speclalisation of the aramatist, acoording to his temporament, rast be considereds

car coms ains1 solt que des homines, les uns sojent greves et sévères, les eutres galllards et joyeux, 11 eat adronu que les premiers 80 sont mis à escrire des Trasédies graves et sévères, 108 seconds se sont exeroez en Comédes zalllardes et joyeuses.2

Belleau's La reconmue and Jean-Antolne de Ball's Le brave and L'ounuque are in comparison quite 1solated. The title-page of le brave, we saw, talls us that it was performed on 28 January 1567 [n.s. 1568], but there is no racord of a play of any other genre accompaying 1t. The "chantz recitez entre les actes de la comedie" are the only extraneous element; in view of 3alf's known interest in music, 3 "recitez" may well mean "sung". It is only surpriging that

1 Boswell in seiroh of a rife, London, $1957, \mathrm{pp} .141,146$.

2 Grévin, Ihêâtre corjolet, p. 9.

3 Cf. Frances Yates, French acodemieg of the sixteerth century, London, 1947, chapter III. 
Balf, who even founded the Acoulenle de Nusique et de Poésle preolsely in order to recreate the pratioe of the anciente in uniting poetry and musio, was not also interested (as far so wo inow) in unitin: forms of drama.

After the Plelade, no such ideals of the union of the forms of drema seem to have existed. "riters oertainly mrote soth trazedies and comedies - both the La Tallle brothers, d'Ambolise, Perrin - but not usually, apparently, for performanoe together. In the prologue to Goderd's Les despuliez, there is a reference to the performance together of Godard's trasody La Franciade and his comedy:

Car on a blen voulu, pour mieux vous contenter, Dessus cette eschaffut icl ropresenter Ces deux poèmes-1à, qui vous feront antendre Que la fortune pout ses longue mains estendre Aussi blon sur los srands corme sur les petitsl

and although this is not reliablo eridence of an actual performance, It does show that Godard is atterpting some meaningoul relation between the two plays. He also olaimed that he was the first in frunce to wite both kinds of play, but this is the claim either of 1 morance or of impucence. - Finally, with the classical generation - Nalret, Corneille, Rotrou - we have plays of both kinds, in considereble

1 Ancion thêtre frungais, VII, p. 340. 
numbers, but written xether as part of their authors' varied dramatic production, not for performance together on a single ocoasion.

Comic structure in thoort and practioe

Comio theory in the Renalgsanoe, as we san, wes basod above all on the commentarles of Donatus on Terentlan praotice. Beare quotes lilohout as saylng that "the remarks of ... Donatus involve absurdities which would do honour to a professional humorlst", ${ }^{1}$, but at lesst in the Renaissance the remarks were taken perfectly seriously. On the question of the overall siruoture of a comedy, the centrel point at issue is that eccording to Horatlan precept and the versions of Grook and Roman plays which the Renalssance knew, plays should have, and did have, five acts; yet the arlototelian division involves only three divisions, a begtnning, a middle and an end, or as Donatuo puts it (apart from the prolosue which is a nere introduction), protasis, epitasis, and catastrophe. Donatus' statement is as follows:

Comoedia per quatuor partes dividitur: Prolosum, Protasin, ipitasin, Catastrophen. Prolozu s est velut preafatio quredan fabulae, in quo solo lioet praeter argumentur allquid ad populum, vel ex Poetao vel ox

1 w. Beare, The Bomen atare, London, 1955, p. 207. 
1psius fabules vel ox actoris cormodo, loqui. Protasis primus est actus, initium drammatis. Epitasis incrementum, processusqu turjarum, ac totus, ut 1ta dixerim, nodus erroris, Catastrophe conversio rerum eat ad lucundos exitus, patefeata cunotis oognitione gestorum.1

Jacques Peletier du liens takes over these 1deas:

La Comedí a trogo partiṕs prinoipalos, sans 1o rrologué. La prómiare, at la proposition du fqt, au prómier sctpi. Iaquale ot apelo des Gréz Protas16. I an olo s'expliqué une partió dó tout l'Argunint, pour tónir lo pouplé an etanté de connoptro lo surplus. La spoonde, t I'auncóment ou prosres, qué les Gréz dispt Epitasic. C'ot quand les aferós tombét on dificulte, o anturd peur e esperancé. Ia tieroc, ęt la Catastrofó, soudeiné conupreion des ohosps au mieus.?

And the same 1deas mere taken over by most Renaissance thoorists. Beare put it as followss. "The scholsrs of the Renaissunos did thelf best to reconolle the two theorles, five-act and three-part, but I aeree with Leo ... that the two are matually exolusive. "3 ${ }^{3}$ The difficulty was certainly present. Sut in fact, as we shall soe below, the act-division of Manclssance comedies was relatively

\footnotetext{
I De tragoedia et comoedias quoted from H. W. Lawton, Eandbbook …p. p.

2 Art Poötique, ed. cit., II, Vil, p. 187.

3 Beare, The Roman atace, p. 207.
} 
unimportant, the action sometimes appearine to be perfectly continuous from the end of one act to the beginning of the noxt. and theoretical diacussion of the parts of a comedy and their dispostion was moh more often concerned with Donatus' three parts than with act-division. Scalleer, for instance, anparently analysing the structure of actual plays more closely than many other critics, ${ }^{1}$ concluded that a fourth division was necessary, which he called catastasis:

Protasis est, in que proponitur et narratur suma rel sine deolaratione exitus ... Epitasis, in qua turbse aut excitentur, aut intenduntur. Catastasis, est vigor, ac status Fobulas, in qua res miscetur in co fortuna tempestate, in quam subducta est. hano partem multi non animsdverteres necessarla tamen est. Catastrophe, conversio nejotil exajitati in tranquililtatem non axpectatam. His partibus additus, ut1 dicebamus, Prologus ...2

I propose to examine the plays themselves, which after all are the important texts, to 800 what kfnd of structure was used in pratice. In fact, all the surviving lienirissance comedies could be analysed according to Donatus' and Scallger's

1 "soio a nonnullis tres tantum enumeratas, nos autem ad sibt1liora somper animum appulimus" (Poetices Iibrl septem, I, ixi Eeldelberg, 1607 edn., p. 32.

2 Ibid., p. 33. 
principles, and it will be convenient to follow to some extent their divisions in discussing first the prologue (and epilogue) and then the rest of the plays - whlch may or may not correspond to their divisions. Prse emphssis will be, hovever, rather on discovering the function of such parts in the totel drematic effect than on establishine them on and theoretical grounds.

Prologueg and epilosues

These two sections of the play lie out3ide the formal sot- and soene-division. Both of them aro normally found.s Le reconme and Les reponeurg are the only ones of the regular comedies before Mblite without a prologue, and Lee descuiser the only ono without an epiloure. Heslite includes an epilosue.

The prologue has a lon ancestry, both classioel and nedievai. Every play of lerence has a prologue, the Hecyra even two, in which the author addresses his audience more or less in polemical fashion. Jean Bodel's Jou de 3aint iloolas has a prologue cailing, quite traditlonally by that time, for silence. ${ }^{2}$ Giordano 3runo's Il Candelalo has an Antiprologo, a Proprologo, and a oonventional Prolose; Proterel in Les corrivaws, as we sau, plays with the tradition too, by having his prologue interrupted by someone

1 Ed. F.J. "larme, Oxford, 1951, p. 4 . 
behind the curtain. Shroughout this lons perlod, the prologre's main funotion in terms of the theatre was to ease the transition from the sudienoe's world to the plavers' world. This function is never essential, but it oan be used for comic or other effect. It is only one of a number of devices used to establish a relationship with the audience (others are the soliloquy, the aside, the chorus in tragedy, but by virtue of its position its uses are different from uny of these.

First, el though the prologue is a less integral part of the play than, say, a chorus, it has the acivantage of addressine the audienoe directly. In every one of the prolosios we are considering, the audlence is acidressed as "vous". The specker usually speciflcally states that he is not the author. But nolther does he saj he is an "actor", in cold reallty; he usually loads the audienoo from the inowledse of whore they are, or I the boundary of izlusion, until they and he are within the action of the play. Por exariple:

Ce nonobstant, j'ai sceu de luy [le poète], Comme une chose blen secrette, Gue cesto comedie est faicte Sur le discours de quelque anour cui s'eat conduit au carefour De Salnct-Sovrin; mais jo rous prie, D'autant que vous avez envie D'estre secrets, de tenir ooys Car je roy oy derriore moy Le sire Josse. I

1 Les eabahts, prologue, 11. 62-71. 
Although the speaker is specifically never the suthor, it is never said who he 2a. One may perhap compare the epllojues, whloh perform the corresponding funotion of laading the audience brok over the boundary of illusion, they are all spoken by one of the drenatis personae, who turns to the audience and addresses them directly. In production, any of the nine prologues could siriliarly be spoken by one of the dramatis personize, and way well have boen so intended. ${ }^{1}$

But if this mere all, the prologue would be superfluous; It would be naive to suppose that an audienco is reaily in need of help over the boundary of illuston. In these plays, it has another function: to prepare the audionce for the play by discussing comfe practice and theory and how the particiar play fits into these. ${ }^{2}$ The prolosue to I'Eugene, for e ample, olaims that it is the rirst

1

Orazio Vecchi's L'LFfid rmaso, Ventos, 1597, is perhas not striatiy comparable. But tize prologue of this musical aetting of a comedia erudita is definitely put into the mouth of ane of the charceters, Lel10 (of. fis. 16). So 1s the prologue (the third, normal one) to Il Candeloio, phlch 18 spoken by a beadle. And it is falrly clear (though not conclusirel that the speaker of the prologhe In Iroterel'B Los corrivewx, and Ie Caohe, are the two characters who open the play proper: Brajard and Gaullard.

2

The prolosue to the Jeu de jaint N100las does this toos of. F.J. 'arne's edition, Oxford, 1951, pp. xvil-xvili. 
French oomedy. The prolocue to Los Heapolitainos explains that It is an exception to the uruel rule that comedies are invented to please the "simple populace", and why. Les dessulsez was grinted together with a tragedy, La Ir moiade, and the prologus is at pains to point out that this juxtaposition is intended to show how fortune strikes dom the jreat but merely plays with the humble and 10 aves them happy in the end. These 1deas can be pelantic, as those of Les desguigez cortainly are, but they appear to shor at least that the audionces of these plays, 39 well as th authors, were interested in the theory behind them. For us, the exanination of the prologues, beside other purely theoretical writings about comedy, has some points of interset to offor. First, In the lator plays, the references to varioty as a merit:

Or, j'espère qu'elle [cette conédie] vous plaira, pour estre toute plaine de variables humeurs, affections, plaisirs ot pessions

... Ia gentillesse de l'invention, le bel ordre, la diversité du subject.. ? $^{2}$

1 Les espritg, Ancien théctre frangals, $\nabla$, p. 201. Ify $1 \mathrm{talics}$ (alsc in the quotations below). - The fact that this prologue is translated from the Italian neod not affect 1 ts validity as an expresaton of Larivey's Ideas.

2 Los Noapolitaines, Ancion theâtre frangeie, VII, p. 133. 
Second, the emphasis on verbal style: the above extract from - Les Neapolitaines continues:

Les sages discours, les bons enseignements, sentences, exemples et proverbes, les faceties et sornettes dont elle est semée de toutes partsl

while in the prologue to I'Jugène the list of qualities desirable in a comedy reads:

Guels vers, quels ris, quel honneur et quels mots. ${ }^{2}$

The prologues usually say that their aim is to entertain the audience. Only two, those to Les escoliers and Les descuisez, overtly state a moral aim; the other seven have no reference at all to any didactic purpose (cf. Les Neapolitalnes, p. 134, "plaisante et facetiouse"; Les esprits, p. 201, "J'espère qu'elie vous plairs"). The supposed aim of the prologues, as we have seen, is to ease the audience gently into the play, and it appears to heve been concluded that edification was a recomendation; for of these seven prologues, four belon; to plays whose authors, we know, expressed elsewhere their didactic intentions:

Or je reviens à la Comédie, qui est un discours fabuleux ... par lequel on peult apprendre ce qui est utile pour la vie, et au contraire cognoistre

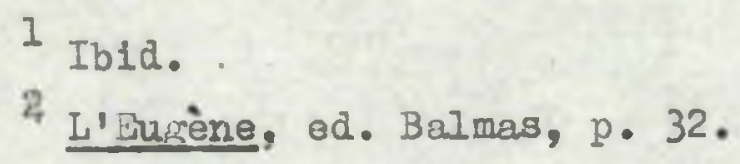


ce que Ion dolt flix, enseignez par le bonheur ou malheux d'sutzu. 1

Touterfolo, considerant que la Conedie, vrey iroüer de nos cuvres, n'est qu'me morale filosorle, donnant lumière a toute honneste disclpline, et par consequent à toute vertu ...2

aux autres qui la liront elle apportera aussi un frand proffiot et contentement 3

None of the prologuas includer the full "Axgunent", 4

but four of them (to LITusene, Les esbahis, Les esprits and Leg

Dontens) state specifloaly that they are not golng to give detalls

of the plot because the play it itself w11l do that woll enough.

Uno play, Ia reconnue, which has no prologue, has a printed

"Argument".

For us, the snowled, of theory of oomody that we can

1 J. Grévin, Brief discours; quoted from H. IT. Lanton, Handbook ..... p. 55 .

2 plexre de Laribus, Fistre to Francols d'Ambolse to the 1579 collection, anolen théatre fransela, V, pp. I-2.

3 irancols. d'Ambolse, Les lespolitaines, preface, Anolen thêêtre tranase1s. VII, p. 239.

4 The prologue to La Ta1110's Les corrivaux gives a food doal of the plot, but st1I? leaves the outoom bor the play itself to show. 
gain from these prologues has its interest. But their ohlef function, 28 we sait, lay in establishlng a relationshlp with the audienoes and It is here that their main interest, and such drumatio quelities as they have, are to be found. We shall return to them, and to the epllogues, in this context.

The epilogues perform the reverse function to the prologres, in bringing the audience back to their own world. They are slways spoken by one of the aotors, who turns to the audience and speaks to them. They axe scnerally shorter than tho prolocues (I Guiene has only one line). As the prologues contained the S1lete, so the ep1lozues contrin the plaudite. Thus Podomont in

\section{Les oontens:}

Mesdames, qui avez pris patience de nous ouIr ceste apresdisn3e, s'il voug plaist revenir on ce lieu le jour des noces de Basile et Geneviefve, vous aurer lo plalsir de volr courir la barue... Cependant, vous ferez bien de vous retirer ohez vous. Car volcy l'houre que l'on comence à soujer aux bonnos maisons. It si nostre ocnedie vous a esté arreable, je vous prie de nous le falre cosnolstre à quelque signe d'allegresse $(v, v 1)$.

\section{ixposition}

The first part of a comedy in contemporary theory was the protasis. Nocordin to Donstus, the protasis is the first act of the play: "rotasis primus est actus, initium druanstis", and 
asain, "rotesis est primus aotus fabulae, quo pars axsumenti explicatur, pars reticstur ad populi expectationem tenenderi". ${ }^{1}$ To some extent, then, it is what we call the exposition. But clearly, the exposition and the first aot are not necessarily symonymous: for instance, in Larivey's Les esprits the exposition is still going on in sot two, by which time Urbain his obtained his Felloiane: the action has begun. Scalijer himself pointed out that tho protasis (evidently for him meening "exposition") of the 1 10s sloriogus comes in sat two (though Balf, in his adaptetion Le bravo, moved It Bllghtly fackend into aot one, soene two). By "actus", Donatus seems to have meant not necessarily an act in our sense (one of five formal sections of the play) but simply a part of the plays and the 16th century underatood protesis in that sense, as the boginning, including the exposition but if necessary also including somo action. Professor Herriok quctes Dryden's Eugenius:

First the protasls, or entrance, which gives Il hit only to the chexacters of the persons, and prooeeds very little into any part of the action. 2

1 De Tresosdia et Conuedia; H. \%. Lawton, Handbook .... pp. $12,14,16$.

2 gaser of Dramatic Boetry; M.T. Herrick, Conle theory in the olxteenth century, Irbani, $1950, \mathrm{p} .117$. 
The important point seems to be how the exposition as such is handled, especially as act-divisfon in our sense, and in this period, is not so very significant in practice.

It is handled with a varying dejree of conventianality. At its stiffest, It consists of cne charaoter telling another details that that oharecter cannot but know already, the toohnique aatirlaed by Sherldan in the Critic: Mr. Fuff, as ho knows all this, why does 3 ir Welter go on telling him?". I Thls is found in only one play: surprisingly, Luzivey's Les esprits, which is otherwise not a stiff or excessivoly conventional play. Hila1re tells his wife ilizabeth details that sh cannot but lonow lreedy, and she 18 so obviously a protatio charceter, a puppet fieure provided for the purpose of the exposition, that she does not oven appear at all in the rest of the play.

One de ree lessstiff - at least It is more honest 1s the exposition by solifoquy. This is usod in three nlays: Los esbahis, La reoonnue and Los dos uisez. The first tio share a pecullar features that the youns lover (L'Adrooat and I'Mnoureux respeotively) is not oven mentioned in the opening soliloguy, and hardly at all until his arrival, in each oase at II, 1. Apart from

1 The Critic, II, 11, Sheridan's Plavs and Poems, ad. R.C. Rhodes, voI. II, Cxford, 1923, p. 219. 
this, in Les esbehis ono soliloquy suffices (I, i), in La reconnue Janne's first soliloguy and Hisistro Jehan's asides (I, I) tells us all except a ninor deteil or two; in Les desalsez two auccessive soliloguies are necessary (but as we shall see there is a atructural reason for these).

The other plays all opon with dialogue that is to some extent motivated. Les contens is the best motivated of all: at the opening of this play Louise has got hor daughter Genevieve up at an unniturally early hour, so that Gonevieve has perfectly good rasone for wasting to know why - and thus justifyins the expowition. This soems to be another example of the deliberate disizise of tho conventlons in this play similar "roalistic" preoccupations also blux the oonventions of décor sivultaie and of time-sequance in it. Ies Nespolitaines and Des escoliers use cialogue in which somo action is elroady taking place: Aucustin is tring to got Beta on to his side, and fiarin is tryins to get some truth out of Finet. In the firat case, some slifhtly stiff expository detalls by Beta ara nocessary, and In the seoond, a supplenentary monologue by inet. I'duciene is perhaps the most plesaing of all: Jodelle quits slmply ontertains us With the pleasures of the churchinen's life, and of Eugene's in particuiar, before ever gettin; down to the exposition. When he does, ho introduces it frankly with: 
d'un cas noureau ...

II'est à ceste heure souvenu

Pour lequal anpells t'avolsl

and the rest of the exposition is made in the same dialogue and In a supplementary monolosio by Hessire Jean (Florimond's late arrival in II, 1, is perhaps surpriaing; compare the late aypearance of the lovers in Les esuehis and he reconnue). The teohnical euse of the exposition in this play is paralleled only in Las contens. The division between exposition and action varios in sharpnoas. Somatimes an atterupt is male to aroid an excessively conventional beginning by intorliniking tho twos thus in L'iu ène I, ili, llessire Jean appears at Gulllaume's house, obojin orders received in I, 1, before Florlmond appears to complete the exposition In II, 1. The plot of Ies esprits is so complex that the exposition is not complete until II, 1 , well after Urbaln has bargained with Ruffin and got his Pelloione (even the denoument of this play takes sore than the usual aot $V$ and ovorflows brokwards into aot IV). An opening in modise res, with expl nations followins, is never used in these plays. 2

1

I'iugène, 11. 220-5.

2 In three plays, strictly speaking the exposition is not complete until the ond, when facts unknom to cherecters and audience alike, and necessary to the plot, are revealeds La reconnue, LoB corrivaux and Les Nospolitaines. 
As woll as being integrated with the action, it is necessary that the exposition should be integrated with character. It is so in L'Dugine, where Thegene's sensuralty is so dvelt on in the first part of the play boforo ever the exposition besins. It is lalso In Les Yeapolitaines, where the dialosue of Ausustin and Beta shows both their ohrracters clearly (Au,ustin the dovoted and deterained lover, Beta the ready-vitted and bribatrle seivant). In fut, ell these plays, evan les esooliers, do consilerably wo:e than meraly expound at the besining the individual character of the spoakers is always made qutte clear (even vizeiseth in Le日 esprits. who only appears in I, i), ant the exposition of the pleys gonerally shows, very competently, the atmosphere that is goins to dominate (the hedonism of Les Neswolitaines, the sour misunthropy of La reconnue). In pleys as dependent on oonvontion as these are, ons night perhaps have expected the expositions to be stiffer than they in fact are.

\section{Catastrophe or dénouement}

It is convenient to take the last part of the structure next. Here practice bears out theory. The catestrophe in Lonatus' words is the "conversio rerun ... ad iucundos exitus, patefecta cunctis oognitione gestorim", and again, the "axplicatio fabulne" -that 1s, a change in the action leading to a happy endin (the opposite of Aristotlets reTá(aris in trajedy) and the revelation to 
aremyone of the true state of things (e.g., that Pamphila is after all free-bom, in the Iunuoh). Scallerer adds that the happy ending mast be "non expectatam". AII this $1 \mathrm{~s}$ very aimilar to the extremely convartional onding of tho nodem detective story: a happy ending and the unexpected revolition of the true state of thince.

Like the expositions, the cetastrophes or dénouenonts are treuted in practice witl a varying de free of conventlonilty. Del ex muohina are not uncomnon. Seven of the pluys employ nuw characters who arrive more or less out of the blue to reveal new fucts, or to influence the situation in a now wa, so that the "happy ending" may bo schlevod. Les Neupolitaines Introduces the now charceter of :uro-iurel, a jeweller from Naplos who his not been mentioned in the four precedine acts. He revoals new facts whloh resolve the situation. WO2: is he the only one: the sub-plot (Dloghos and Gaster) Is fiven another completely new chareoter, the messen;er Louppes, who reveals fucts that persuacle Dleghos to laavo and thus ronove his prosenue from the "happy ending". The arrival of these two new characters is certainly artificials but the ingtery surrounding Angelique's past and the oonstant references to 1 t are bound to wam the reidus that something of the kind will happen.

In La reoonoue, Les corrivaux, Les esprita, Les dosrulsoz, and Les ramonsure, a parent (or parents) of one of the lovers Livolved arrives at the enl of the play and makes the "heppy ending" possible. 
Since the "happy ending" alwass Involves marriage, and since in terms of the plays marrlaje ulways involves settlements and fally details, the very absence of the parent conoerned in a wry prapares his arzival. In addition, there is geherally other prepartion. In Les desmuisez the plot at the end is already tumin upon Olivier's Pather, and Pasetrouvant is havin to iapersonate him, so that his arrival is prepered and affoctive. In Les corrivaus, the prologue has aready told us of the father's existence. In Los osprita, the Ürbain-Feliciane relationship has been prepared frón as eurly as act I, and moreover Cercri's arrival is prepared two scenes before he actually arrivos (IV, $\nabla$ ). In La reconnue, some slicht indic tion of intoinette's father's arrivel in Psris is given early in the play $(I, v)$ when Malstre Johan saษs:

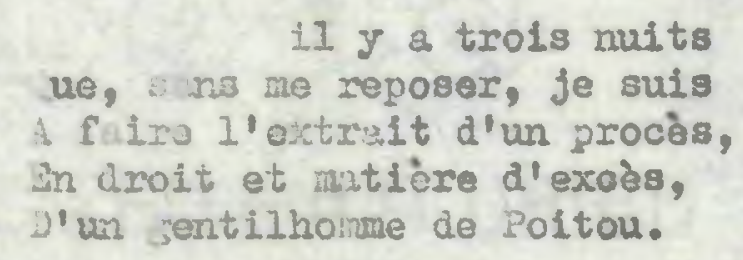

but the main preparation lies in the obvious lack of parents of this girl whose marriage involves so many people. There is a second new character as rell, in tho demouement of this plas: the canitaine, who has been so much discuesod in the preceding acts. Wuoh more preparcition is made for the arrival of hgnès at the end of Les esbahis, whose function is to set Josse out of the 
way of the "happy ending". Fe Grdually learn a lot about her past, and about her affair with the Gentilhomme, before she appeers in at $\nabla$. In all these ceses, ho revor, preparation must not be confused with motivation. In Les desgulsez, it fits the pattern of the plot very well that ierre Gnland should arrive when he does, but that is not to say that his arrelval is motivated in terms of the 2lay. He has simply armived in culouse, looking for his sor, by chance at this particular tive. The same applies to all the other examplegs A ऊnès' arrival may be prepared, but it is mere coincidenoo that she, the Gentilhomme's whore, should turn out to be the same person as Josse's wife. Jodelle, in livuène, achieves a better motivated plot by makins the arrival of a new character, Floriand, the source of his plot and not a mere accidental impinisement upon 1 t. But in the later plays, it is clear that the arrival of new ahoraters hus become a convention that does not noed to be motivated.

The acceptance of this convention is shown by comparing Grévin's Les esbahie with his Le rescrière. Ia tresorière is the oarlier play, and it is completely motivated by charcter, not by del ex maching. Loys' anger' at his rival's success proctpltates the climas, all the reactions to which are In character. Dgapite this early production, however, lin the later play Grêpln lntroducod new charsoters at the end, showin that the intemally motivated dénouement was not, for him, something that need necessarily be aimed at. 
Two other plays have a denouement that does not depend on new characters or fucts: Les contens and Les escoliers. The technique of Les escoliers 19 primitive when cormpared with Les contens, but nevertheless it is true of both that the denonement derives from character and not from chance. In ies esculferes, the inquialtive and meddlesome neighbour iniquet is credibly unlled into working on his neighbour lifaclou to allow the marrisge of sobrin and Grassettes and the fathers keolou and Marin, soeing thst it is after all a perfectly auiteble marriag, credibly decide to allow it after soolding their ohildren. In Les contens similarly, after a good deal of cuarreling the perente of Basile and Genevieve, sceing that it is also a perfectly suitable marriage, decide to allow it. This is not, of course, to condarm the convention of dei ex maching mexely on srounds of artificiallty nevertheless, it is of interest that the convention is not univeral and that La tresorière, Les oontens and Les escollers, at least, successfuly arold 1t. The dénoument of vélite, too, is intormally motivated. Loose ends are seldom left over. The captains often have a marriage provided for them as a conoletion prize (La Ieconnue, Les Terpolitaines, Les deszulsez). Belleau in La reconnue is so concerned with rounding off his play that practically all the charcoters, and what they will receive, are passed in review in orders I'Amourewx and Antolnette, Fotiron, Monsieur, Lladame, Maistre Jehan, 
the captain, Janne. The plot of Les esprits is complex enough with Its three pairs of oventually unitod lovers not to involve auditional loose ands in any case. Las oscollerg and Les corrivaux also have no loose enda. In il Luene, Matihleu the oreditor is introluced so late into the play that he is hardiy an integral part of the plot; nevertheless, he is not merelj a loose end to be dealt with, for the way husene satisfies him is an effective demonstration of their respective characters. Los esbahis alone does not end so tidily. At the end of the play, H'Adrocat'B disguise is st1ll unknom to Gexurd, the guilt being attributed to Panthaleone. The revolation of the facts, and the mixribse of L'Adrocat and Hadalène, ara marely promised to the audience in the opilogue and not actually arranged within the play. But this is a solitary and not pexticularly oi niflcant example. There are no oases in these comedies where the play significantly ends with a question maxk, like lartuffe, or Le issinthrope, or Trelfth Mint.

Fitasis and catastasis

The part of the play between exposition and denovoment is less clear-cut than eithor of thom. One signifloant queation 18 whether or not a elimax occurs at any point to divide it wp. ta rooonmue, Los egprits and Les desulsez have no such obvious climax. In the first, the unusual lack of a climux serves to build up the 
susponse: Nonsiour's mchinations come nearer and nesrer success until, only in the last sot, he is finally folled and the atmosphere clesred. In the second, the plot's complexity is sufficient entertinment in itself to sustain a single level of action throughout, and the three pairs of lovers almply continue to manace or mismanage their affairs until the dénouement. The success of Les descuisez depends on the sradusl complication of the intrigue through four acts, one disguise and doception involving another, unt1 the disguises are broken dom, in strictly reverse order, in the list act. In $s i x$ other plays, the course of the action is changed about the holf-way point. The ohange is precipltated by a seduotion in Les contens, sot III, and in Les osbahis and Les Heapolltaines between acts III and IV; by Richard's discovery of his master!s rival's success in act III of La tresorière; by Florimond's violent removal of his funititure in sot III of LlBusène; and by an attempted rape in act III of Les corrivaxx. In each case a reaction is provaited. Let IV of Les contens is occupied by Basile's attempted prevention of that reaction; aot IV and part of act $V$ of jes eabahis by GeIard's ohaffin; of Josse about the seduction, and Josse's violent recotion; act IV of Les lenolitainos by Cisoussion until the dei e.c nowhing of act $V$ provide the solution; 0ots IV and $V$ of Los corriveux by radual resction and solution; so that in esch osse the cllmax ohanges the course of the ction. In L' inzane there is a differenoe, 
in that the removal of the furniture is not an unexpected disaster, but in a similar way resctions and oventually a solution are provoked.

Les esoollers repressonts a variation on this techniquo. The climax occurs, not half way through the plot, but in act IV. After three acts of discussion and plotting, suddenly in sct IV the pace quickens, a plot is laid, carried out and discovered ali in the coursecof the act. It la quick, and effective; but the execution of this play as a whole is not good enough to carry it off.

The theoretical discussion of this part of a comedy, In the 16th century, concems the meaning of Donatus' third part, epitasis, and of soaligex's added fourth part, catastasis. Donatus calls tha epitasis "Increnenturi, processusque turbarum, aa totus, ut 1t dixerim, nodus erroria", ${ }^{1}$ but as the term by ellmination has to cover everything between the protasis and the catastrophe, this seoras a little vague. It soems to we that scalifer's two torpa, between thera, are tuch more closoly related to seturl dramatic practice both in Terence and in our comedies.

Ipitasis, in cua turbie aut excitantur, aut intenduntur. Catestasis, est vigor, ac status Fabulac, in qua ris aiscetur in ea fortune terapestate, in quam subducta est."2

\footnotetext{
${ }^{1}$ E. . . Lawton, Hendbook...., p. 12 .

2 cr. above, p.
} 
For example, in Les Neapolitaines the epitasis would cover everything that happene up to Camilie's seduction of Virginie; that seduotion and 1ts immodiate sequels would be the oatastasis; and the solution of the problem, the catastrophe. It will be seen that the "climax" I have been discussing, and which I see as an important part of the dramatic struoture, is in fact very close to joellger's catastabis.

\section{Pertis and obstacles}

One of the main principles of plot-structure in these plays is the gradual removal of obstacles or perils in the way of the prinoipal characters' ends. Thos ende may be either moral or immoral. Sugène's alm is to enjoy Mlix at his lelsure; Loys' and the Frotenotaire's aim in La tresoriere is to enjoy Constantes Basile's aim in LeB oontene is to marxy Generiève (even though his methods may be the reverse of moral); Olivier's aim in Leg deszulsez is to murry Loulse. The morality is irrelevant. In terms of plotstructure, the action is bullt on the removal of the perils or obstacless Florinond's anger in L' Jukene, toulse's obstinsoy in Les contens, and so on. The most frequent pattern is a double ones the young lover first has to win the girly and then has to obtain the approval of soolety for marrying her (Les esbahls, La reoonnue, Les corrivaux, Les esprits, Les contens, Les Neapolitaines, Les 
degulsez, ies escollerd, Les ramoneure). In terms of the structures we have been discussing, the overcoming of the first obstecle is Soalicer's catastagls; the overomin of the seoond, the catastrophe. Althouch this applies to nost of our comedies, some like ' waje have only one obstacle and so are outside this definition. Melite is a variant on this pattern. The obstacles to Tirsis and Mélite are Eraste's jealousy and machinations we see how they begin, suoceed, are discovered and crercome, and almost the whole action is built on thess. The second obstacle, obtaining social epprobation, 1s stlll there in the shape of N61ite's mother's approval, but it is 80 played dow that $=2$ are hardly aware of it. The perils and obstacles are still the basis of the plot, but they come from the characters theraselves, not from society outside; from other members of the sane generation, not from an olcer generation.

The multiplieation and removal of obstacles, then, form a principal feature of the plot-structure of these comedies. Te have the testimony of Raysiguler on the sudiance's reaction to 1t:

La plus grande part de ceux qul portent le teston à l'hostel de Bourgangne veulent que l'on contente leurs your par la divergité ot ohangement de la face du Theatre ot que le crand nombre des accidens et adventures extraordinaires leur ostent la cognolssance du sujet.I

1 De Rayssiguler, proface to I'Aminte du Tasse. Iragi-oosodie ... 
Though Raysiguier wa doubtless referring mainly to trogi-ocmedy, behind his exagferation there is some truth for comedy too. The truth is that there are often a number of "acoldens et adventures extraordinaires", the exaggeration, in that an audience if it is attentive is never forced to lose the thread of the plot. Charistere on stage may be decolved, but we, the audience, are always aware of the deception. Thus, in Les esbahis, IV, 11, Gerard believes that L'Adrocat is Josee, but it has been made quite olear to us that in fact L'Adrooat is disguised. In the same play, the moman discussed by Claude and to Gentilhome (act III) is in frot Agnès, Josse's wifej as soon as it becomes nocessary for us to know this, we are told 1t.

Disguises and plot-structure

One mitht have supposed, from the reputation that Renalsganoe comedies have ss plays of complex intrigue, that disgulse and deoeit played a fundamental part in these plays. But in fact, only one of them uses disfulse and decelt as the msin structural principle of the plot, and it is indeed called Les dessuisez. In this play Clivier, the hero, disguises himself as a valet; but then,

... pastoralle acoommodie eu Theatre Frangois, Par1s, 1632; quoted prot Y.C. Lancastar, "De Rayssiguter", Rerue d'histolre littéraire de Ia Brance, XXIX (1922), p. 263. 
needine to introduoe himself in person, is obliged to use his valet disguised as himself; when his valet promises to prociuce his father, and this is not poseible, a further impersonation becomes necessary. At one point in the play, we are confronted with a true olivier and Plerre Galand, and a false pair of the same. The plot is built up upon the multiplication of disguises and upon their remoral in reverse order. ${ }^{1}$

In all the others, disguise and deceit are only a means of complicating the plot. The climax of the play 18 sometimes the discovery of the disgulie or deoelt is but this is not to say that tha theme is the fundamental basis of the plot. In Les esoollers, four and a half acts pass before the disguiae is adopted to enable the hero to attain his ends, and then it is put on and disoovered in the course of a single act. In Les Nespolitaines, the only deceit is Camille's mothod of jettine Cornelle out of the wey, a very minor part of the plot. In Lisugans, only Guillawme is decelved; but the action does not turn upon Guillaume, but upon Florimond, who is perfectly aware of the situation. In Les esbahis and Les oontens the climex results from the disgulse, but nevertheless is only ono element

1 The sequence of disgulses is taken from the play's model, Arlosto's I Suppositi. Nevertheloss, some important ways in which it is used and developed are Godard's: Jaudole's brasging in his master's clothes, and his confrontation with Frouventas. 
In the plot anone others. La reoonnue, admittedly, uses the theme rather mores Lonsieur's atternt to decelve his wife runs through all the play, while one pretence gots out of hands the csptain is announced to be desa, I' hmoureux plans to pretand he is alive, and in fact he tums out to have been alive all the time. - Although the theme oocurs in all these plays to some extent, it is never fundamental to the plot in the play in whioh It is In, 8av, Du Byor's Les Vendanzes de Suresnes or Molière's Tartuffe. Nor do we jet have a pretence lesding to a reality (as in Rotrou's Saint-Genest, where the actor playin a Christian bacores a Christian). Perhaps its most aignifloant use is in the irony of Les contens, where real and pretonded piety are continually played off agalnst each other.

Nevertheless, the theme has its importance in the relationship which it makes possible with the audience. As we have soen, the audlence is not deceired in these plays, but always knows perfectly well who is disgulsed as whom, snd preclsely what deceits are being attempted. The lnte set lles in watching the charaters' reactions, and how the deceifts aro made and exposed.

Linked with this, and with the same kind of function, is the discrepanoy betwoen what is and what is not. The brasgrart soldiers claim to be brave but are regularly shown to be, in fact, the opposite. Josse in Les egbahis claimg to be strong and capable of maklag loves in fact he has a cold and has to sear a fur coat. The 
audience knows the facts very mell in esoh case, not oniy from the plays themselves, but from the tradition whioh told them that a braggart soldier or an old man in love were not to be taken seriourly.

Act_ and scone-division

In 20th contury pleys, it is normal for an author to specify the divisions and subdivistons which he requires and whioh a producer nill generally respect. He may use the division as a means of variety and contrast; after a scene of galety and moroment the lights may be dimned, or the scenery changed, for a more subduad scene. In the plays we are conoldering, the divisions are much 1088 clear. Slnce the stage set was bound to remain the same, or almost the same, throughout the performance, changes of scene could not be used in this way for contrast. Speeoh and the entry and exit of characters were the main means avallabley and the formal soene-division in these plars in in fact based entirely on the entrance and exit of characters. A character may leave the atage entirely; or he may simply drats naide to another part of it, whence he may return a scene or two later (thus, perhaps, Les descuisez, IV, 111- $)$ ). Orten it is not olear which is intended, nor does it need to be made clear, the question beins left in the hands of the actors. The result is that the indicated soene-division is 
less formalised then in 20 th century (or even 17 th century) plays, and that there are considerable inconsistencies from play to play, anc oven within a single play. ${ }^{l}$

The theoretioal basis is simple. Charles Estienne 1s typioal:

Guand devx personnaijos ou trols avolent devisé et tenu propos enserible, at que l'ung se retiroit, ou qu'il en venolt ung aultre en nouveau propos, 1lz appollolent cela une soene, o'est a dire commutation ou variation de propos.2

Lonatus also linked aots and scenes with entranoes and exits, but took the principle to absurdity: "No oharacter who has left the stage five times can exit any more" - whlch Scaliger saw was, to start with, 11terally untrue. ${ }^{3}$

La tresoriàre, Les esbahla and Les contens are, in fact, the only plays whioh are consistent within themselves. Is

1 The sceno-diviaion is not necesserily antirely the work of the author, and It may be that the printer, or a copylst, or other intermediary, had a hand in any inoonsistenoles.

2 Eplotre du traductoux au lecteux, Andrie, 1542 (H.W. Larton, Handbook $\cdots$, p. 38).

3

Donatus quoted from Herrick, Comic theory ..., p. 109. Sealiger: "Personam eandea negat Donatus plus quinquies exire in presoenium, falso. Vel statir ipsa in sndria Davus ootendt haud ita ease, tum allbi saepe" (I, $1 x_{;}$od. c1t., p. 35). 
trosorière and Les esbihts adopt one simplo prinoiple: the entry of a now charicter entalls the declaration of a neir scone. Thus, in Les esbahis, V, 1, Futhulecne has a soliloguy overheard by Jullen; dialogue between the two follows. Then new chareoters enter and V, 11 is declared; but Panthaleone and Julien romain on-stage and a page or two latar, wthin the same scene, roturn into the convarsation. Les contens adds to this the principle that when a character is left alone on-Btage for a sollloquy, a new scene is deolared (I, Vi, eto.).

None of the other plays is so conalatent. The two basic principles remain the same: that the entry of a new charecter or his isolation on-stage for a soliloquy entails the declaration of a new scene. But in every case there sre exceptions. In Le reconnue, IV, 11, lladame enters in the mlddle of a scene, and a new scene is not deolared, whoreas when she entered after III, 1 the normal prooedure was followed. In Les esprits, V, i, Ruffin knocke at the door, Severin appears and a new scone is doclarod $(V, 11)$ as one would expects but in III, i, Prontin had knocked at the door, Urbain had appeared in exactly the same way, and a nex scone was not declared. After Lee deszuisez, III, vil, Olivier has a soliloquy entailing a now soene; but in II, 111, Grégolre's soliloquy does not entail one. Sirilar exanples are found in all the other plays, including ses lite. 
It might be thought that these inoonsistencies are In fact intended, that they ropresent something to do with stage produotion. This does not appecr to be so: in the exarples I have cited (and others could be fiven) the inconsistencies occur in peosages as nearly parallel as could bo. "He must oonolude that al though the basic prinoiplos remain oonstant, the details of the scene division cannot have been regarded as greatly sijniflcant. and in fact, of course, they are not of the greatest simificanoe. If the entry of a character (posaibly a very minor one) should justify a new soene, why should not his exit? Important divisions in the plays must be based on more fundamental oriteria (0.5., a turning point in the plot, or an obviously important ontry) rhioh the producer and act fors then as now must deoide upon.

In one 1solated oase things are different: Perrin's Lee escollars. The division here is based upon other prinolples, and noither the entry nor the exit of a character entalls a now soene. Thus, in the inidale of IV, 1, Corbon snters and no new sceno is declared. And a typical plan for a soene in this play precisely involves an entry in the middles soliloguy by $A$, entry of $B$, sol1loquy by 3 , dialo ue between $A$ and $B$ (thus I, $\nabla ;$ II, 1 ;

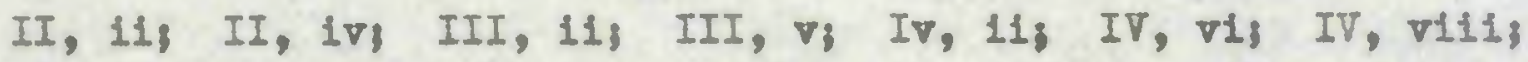
$\nabla$, 111). The prinoiple that is adopted appears to be that of a break of a tableau in performance, as is perfectly possible with 
décor gimultane. The acts are much more split up than usual; whereas, for example, in Les esprits act I, like the other acts, oontinues without a break, here act I consists of four separate tableaux: scenes 1 and 11 shows llaclou and Finet, scene 111 Grassette and Babillo, soene iv Jobrin, ani scene $v$ Friquet and arin. The prinolples of construction and consequently of scenedivision are uite different. Aot-division is less important than it is in later plays. The structure of the plot doss correspond to some extent with the act-division, but the oorrespondence is not at all strict. ${ }^{1}$ As far as elther narrative or atage production is conoerned, the division between two acts often has little more si gnificance than a division between scenas. In Les Nerpolitaines, II, 1 simply carries on the action of the last scene of Act I (Ir), the same two characters being on stage without any apparent break in time. In Les desizisez, movin; to the other extrene, a day or more seems to elapge at some point within act III. If the diftsion vere nomally more important, one mifht sey that in both these oases (and in others)

1 Far less strict, either in classical or Renalssande practioe, than Josse Bade's analysis of Terence would su geat: "In primo horum actuui ut plurimum explicatur arejnentum. In secundo fabula aji inolpit ot ad finem tendere cupit. In tertio inseritur perturbatio et impedimentum et desperatio rel conoupitae. In quarto remedium aliculus interventus affertur. In quinto autem omia ad optatum finem ut lam saepe dixl perduountur" (Iraenotamenta, Lyons, 1502, xix; Handbook,..,p. 30) 
the dramatisto oonoerned rere deliberately departing from a convention in order to obtain a partioular effect; but this does not appear to be the case. Sometimes it would be diffloult, without the written indications, to arrive at the same division into five acts as the author has ostablishod. Thet division may well be a concession to the contemporary theory of comedy, not an obst3ole but at the same time not a thoroughly integral part of the atructure of the plsy. It 13 clear that we should not sive too sreat siznificascs to it. The prinolples of construction are not dependent on formal scene-division, nor are the "realiatic". Chamard orticised the sceno-division in I' Suriene and La reoonnues

Les soènes se suivent et ne se lient pas. ${ }^{1}$

Les scènes a'y suocèdent à peu près au hasard, sans préparetion, sans enchainement.2

But these plays sain thelr of foct in othar ways, and the criticiom, though posalbly vilid for the 20th century armohair resder, 18 anachronistic.

Time-8equence

- - - - - .

1

Iistolre de la Plélgde, II, p. 18.

2

Ibld., III, 291. 
Ono other convestion of plot-structure remalns to be discusied: the time-seinence. In every play except Les desinulsez, Les ramoneurs and Melite, the unity of time is observed, the action takin; place within at most one day. Sometimes the time of day 1s explloitly and oarofully atated as the play goes on sometimes it is very vague. Five plays begin in the morning and end just before "souper" (about 6 p.m., according to Les contens, $V, \nabla 1)_{3}^{1}$ four state no precise times LOB dessulsez occuples two not necessarily conseoutive days; Les ramoneurs besins in the afternoon of one day and finishes two hours before supper the next; while Ulite, wuprisingly, is the sost loosily constructad of all. I' Du èng is one of the five. At some time before III, 1, hessire Jean was "bancueting" with Gulllaume and Alix; we presume this was the midday meal. In $V$, IV, Borimond says "desjà la nuict s'approche", and in $V, V$, the sreeting "3on solr" is used and supper

1 The terms used for the tro main meals of the day are "disner" and "souper", which I shell translate, for purposes of clarity, as "lunch" and "supper" respeotively. The examples fiven by Z. Husuet, Diotionalre de le lanue frangalsetlu seiziène slèole, vol. 3, Paris, 1946, pp. 208-9, show that "disner", when It did not mean "breakfast" (and 1t appears not to be used in this sense in the plays, where "déjeuner" is used, as In La reconnue, I, 1), meant a meal at uldday or shortly after. 0. Bloch ani ". vor Wartburg, in their Dictlonnalro atymolorique de la langus frangaige, Paris, 1950, p. 176, state that "Io premier des deux repas quotidiens ... avalt lieu vers 10 heures au XVI siècle", but this is not confirmed by any text that I lcnow. "Souper" 18 regularly the evening meal, served sbout 6 p.m. 
is beins prepared. Other Indio tions of the passing of tine, however, are few.

Le reconnue ulso occupies one day: it begins stralght after the night $(I, 1)$ and ends just before supper on the same day $(v, v)$. Is in L'turène, other indications are fev.

Les esprits besins in the morning. In I, i1, Hilaire Gives orces for the preparation of lunch. In I, $\nabla$, Frontin goes off to prepare lunch for Fortune, and one $\mathrm{mi}$ jht assume that by his next appearance (II, 1), he had lunched. But as late as III, vi, rrontin says to Severin "Venoz disner"; this may be simply inadvertence, or wore likely may servo a dramatio purpose in omphasisin, the fact that Severin is so harassed that he has not eaten. In V, vil, Frontin goes off to prepare supper.

Les contens contains inore preoisions wbout time that any of the above, but each one sorves a dramatic purpose. This, in I, 1, it is so eurly that the sun is not oven up, and the conversation bears very laregly on why Louise and Genevieve are up at this unueually early hour. In II, $v$, it strikes $10 \mathrm{u} . \mathrm{m}$. Lunch is esten. An assigmation made for 1 p.is. is carriod out in II, ill. In IV, IV, the freeting "Bon vespre" is used. In IV, $r$, Loulse savs it is an hour and a half since she locked "Mustache" Into her "salla" (III, vi1). In $V, 1$, Anthoine asys it is an hour sinoe he went on his errand (IV, i). In the last scene of the play $(V, v 1)$ Basile says "Bon solr" rather 
than "Bon vespre", Louise says it is nearly $6 \mathrm{p.m}$. and invites the company to supper.

Les Neapolitaines is also precise. It oocuples from "early" In the moming (I, 1i) until Just before supper. In II, 111, Diejhos says "Je oroy qu'il s'approche de midi". It is the hour for lunch; Augustin and Angelique have this meal betwoen III, ii and III, v, and Dleghos and Gaster between III, 11 and III, vi. As early as III, xill, Camille is able to plan to send Comélie to do the shoppin for supper, and in $\nabla$, ili, the host of the Esou de France gtvos orders for tiaro-Aurel's supper. In $\nabla, x$, Louppes says he has been looking for Dleghos for elght hours - presumably since the morming. At the end of the play, supper is about to be served the plauite takes the forms "Jernenez les malns, et moy les dente." The four plays that are not preclse are la tresorière, Les esbahis, Les corrivaux and Les escollers. The total references to time in these plays are as follows: In la tresorlère, as early as II, 111, we hear "Vous sçavez qu'1l est desjà tard", and the epllosue refers to a banquet which is about to be prepared. - In Los esbahis, by II, iv the mass is over. In I, 111, Penthaleone is said to come in the evenings but this can hardly be true of both his serenading appearances. There are, I think, no other Indicetions; but the play could well take place in a single day. - Les corrivaux, too, could occupy one dey only. By I, 11, soms of the dey has 
certainly passed ("je n'ay falt que trccasser por toute la villo powr volr si je trouverais Claudo ..."). In IV, 111, Foll: save "nous n'avons point souppê", surggesting that supper-time is not far awey. The traditional invitation to supper that one might have expected at the ond does not ocour. - Les esooliers is not merely imprecise, but clumsy. Mready in II, i, Finet says "Le jour cormence \&े se belsser"; but still in V, 111, it is not yet sunset. Betveen IV, IV and vi Sobrin has entered Marin's house, seduced Grassette and had a long conversation with her which is reported in scene vis the shortness of the time is excessive even for the convention.

Les dessuisez, the last of the 16th century comedien, is the oniy one of them that does not observe the unity of time. In III, 11, Olivier offers his sorvioes to Grejolre as valet, and in III, $v$ ho is well established in the household, having shom that he oan play the spinet, read and rite, and plense Gregolre. The artiflciality of this speed night perhaps be ovorlooked but In fict even within the play's own terms two separate days mast be concerned. In I, 111, lunch is served and Clivier and Maudolé go off to eat. In II, $v$, Maudole has fresh nows for Olivier, so that we must assume that time has passed; then olivier offers his sorvices, is acceted and ostablishos himself and then in III, $v$, Louise says "despesohons nous, de srace, / D'aller aprester à disner". 
This would be impossible if one day only were mant, but an the other hand there 18 no clear $8 \mathrm{ag}$, so that watever intention one assumes, the exooution is clumsy. In $v, \nabla, a$ banquet, presumativ supper, 18 about to be served, yo that the first dsy ocoupies from before lunch to after 1t, and the reoond, not necessarliy oonsecutive, from before lunch to just before supper.

All the 16th oentury plegs, then, except only the list one, Les desculoer, take place within one day. Four plays do not give dotalls of the passing of time. All the others oocupy from morning unt13 just before supper: that is, a time longer thar the play would take in actual proluotion. Therefore, an artiriolal druatio convention is regularly being observed here, that the supposed time is longer than the acting time. This 18 nornal and acoeptable enough; but sometimes the artificiality is pressed to such a point that the convention demands more than pessive accoptanoe. Thus, in Les Neapolitaines, III, xill, Camille tells us what Anefélique, Augustin and he have dono sinco scone $x 1 ;$ and in III, $x 11$, Gaster tells us what Dieghos hes done sinoe scene V11; in esoh oase the time nesded would be obviously much more than the acting time. At two points in this same play, no timo at all is allowed for an sctions In II, vili, Augustin sents Loys on an errand and already in the next soone (III, 1) is impatientIy awalting his retum, while in III, xill, Comillo plans the seduction of Virginie and wroedy in the nent scene 
$(I V, 1)$ bo has carried it out. Porhspa intervals or at lasst saps

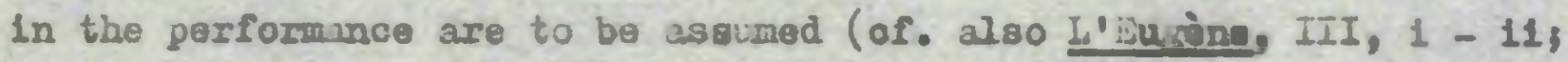
III, 111 - IV, is IV, $\nabla-V, i_{3}$ L8 roconme, $V, 1$ - i1; Les corrivon, III, 11 - IV III, 1 - IV, 1; Les esprit8, II, $\nabla$ - III, 1).

Les contens, as we sam, minimised the artifiolality of the déoor simultand oonvention by the assumption that the complitments were noar bach other in terms of the play itself. It elso minimises the artificiality of the time comantion, in two ways. Hrat, whereas Iea leapolltaines usually allows only a soene or two for a roported action to take plsce (soe cbove), Lel contens usually allowe plonty of tinse (e.8., Rodomont is led off to prison in III, 11, and rotums free In IV, 11). And second, although the play is preolse when need be (for example, in the huxpy of the early morning in I, 1, when the churah bell is heard soundin; the parts of the mass), when thero is no dramatio neod, it is varue. Host of acts III and IV take pla.0e simply in the "après-dienée", and ve foel no lack of any lndicetion of time, whoress in Les asbahls such a laok was jarring (why does Panthaleone give two serenedes in one day? eto.).

In La reoonma, a partloular kind of atmosphere is created by the passing of time. Everyone la in a hursy. It 18 time for Janne to get supper, or for lotiron to report to his master, or Honsleur cannot wait until night falls. The play is unique in this, chli jains by it in two wavs. Elrst, the play is obviously more ilvely 
If speeded alongs second, this sense of hury fits in well with the atmosphere that Bolleal is creatins. In fact, he has drom for us a set of complalinin and selfish peoplo: Janno sick of her job, Jadame tormenting Janne andiher husband, the inciulaitive Volsine, the adulterous kansieur, Malstro Jean and the Centilhoume de Folotou complaining of the law courts. The!r inablilty to be oontent with the moment is part of their character, and part of the charsoter of the play.

Le日 ramonurus and alite, perhaps surprisingly, are the only penah Renalssanoe comedies whose sotion frankly oocuples more than one day. In LeE rehoneuxs, I, Vil, the Captain says "dillans now coucher", and in I, vill there is a serenade in the "douce at farorable nuit", after wich the cutain says "Il sers decialn jour". A whole ntight, then, aust be supposed between sote I and II. On the other hand, the action ends, exceptionally, two hours before dinnar: In V, v111 the Captain agks for "uno couple d'houres de lo181r au preparatif du souper"3 so that the aotion does not take wore than 24 hours. - Wilte is the loovest of the plavs, since on Comeille's own admission in his Ixaman a weok or fortulight must be sssuned between acts I and II and ajain between acts II and III $\left(0.80,1.542{ }^{~ " C e}\right.$ que depuis hult jours je bruslols de sqarolr"). As with the decor, the details of the tire-sequence can only be discovered by combing through the glays. Te generelly find 
then there only when they are essentlal to the plot (indoed, sometimes they are omitted there they seem necessary) and where they serve some dramatio purpose (especlally L'Dureme and Les Meapolitalnes). They do not seem to be there as part of a purely ilteral and non-scenlo convention.

3. Charaoter.

3ixtoenth oentury theorles of oharacter in drama are dominated by the prinolples of doourum found in aristotle, Cloero and Horace. Aristotle numes slx oirounistinces that differentlate Indivicuel men: cmotions, hablts, aje, fortunes, sex and nationality, and says thit the writer should:

endeavour always after tho nooeseny or the probsblo; so that whencver suoh-and-such a personase says or does such-and-swoh a thing; It shall be the probable or necessary outcome of his charisoter.?

Cicero, writing in the Crator, seyse

Horeover the orstor wist have an eye to propriety nct only in thought but in langrage. For the same style and the same thouphts mat not be used in portraylag every condition in $11 f \theta$, or every rank, position or aro, and in tiat a siriliar distinction must be made in respect of plooe, time and audienco.

1 Guoted from E. E. Loblns, Dranatio Char oterisation in Pxinted Commenterien on Feronce, 1473-1600 (IIIInols studies in lansurso and I1terature, X(XN), Irbana, 1951, p. 38. 
The universel rule, in oratory as in life, is to consider propriety. This depends on the subject under discussion, and on the aharioter of both the spoelrex and the audienoe.1

a statement about rhetorle applicable to Iitereture and therefore to comedy too. In Iife, Casticlione's Courtier applied the conoept to sociel intercourse. Guintilian's disouscion of the term with noference to oratory even comparod comedy:
In the case of the doclaimors indoed it is of the first importance that they should consider what best suits eoch cherscter, for they rarely play the role of adroostes in their deolanations. As a rale they impersonate $80 \mathrm{ons}$, parents, rioh men, old mon, sentle or harsh of teraper, misers, superstitious persons, coweurde, and mookert, Bo that hardiy even comic actors have to ascume more numerous roles in thelx performanoes on the stage than those in thein doolsmations.?

The list sounds like any of the Iiste in Frenoh Renaissance thoorists, clearly derived from Ierentian pratioe, which we aramined In the chapter on comic theory above.

Such 1deas, of oourge, tell us hoir dramstists ought to handle characters once they have created them but not what sont of

1 Quoted from H.T. Herrick, Comlc theory in the olxteenth century, Urbana, 1964, p. 136.

2 Ibid., p. 133. 
ohsracters they oujht to oreate. In lict, in Prench Fendisaunce comedy the characters ane those of Prench bourgeols soolety, rystematioed into a number of types at first based on native frroos and on Terence, and later set into a sholo oomic tradition. ' They are of course floures of their om time: the rolationship of the valet to his master 18 the 16 th contury reletionship, not the Joman cne, and the relet lonship of the younger and older fonerstions to each other la entirely that of Renalisanoe society. Sinco comedy in Frnee was bors in a Univorsity nilieu, University char oters are often found in the pleys: the young lover, especially, is often a student (La reoonnue, Les Jeapol1isines, Les ramoneura, etc.). Somotinge he is specificaly a law student like L'Amouroux in La recomue - and indeed, at a later date, 1kko Cornolllo's horo Dorante in Lo mentour.

It was concluded that these characters vere flctional, and therefore mi ght have whatever names the dramatist ohoose to Elve then, and alght behave as the druiftist wished. Howevar, the very fact that people established 11 ts comedy, considered as standerd for comeáy in goneral, meant that comlo charscters were looked upon not in the first place as individuais,

1 cf. H.W. Lawton, "La survivinoe dos personneses térentiens", Bullet1r de 1 'Aseooletion Gul1leume Budé, 1964, 85-94. 
but as a series of flsuros ropresentative of definod human typos. The question of how far a oharioter in a comady should represent a

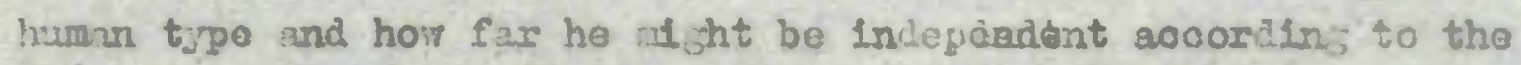
dominds of the oomody, wes much disousseds that 19, hor far he should observe soolal decorium and how far dramatlo decorum. Thus, the 1mpertinenoe of the slave Davus in Andr1a, III, 11, 492, was condemed as Indeoorous by W1121chtus, ${ }^{1}$ because a elave should never sook his master. Dramitically, hovever, it is olear that Davus! impertinenoe 1s effective. Donatus applles the different kinas of docorurs thus, on lititio $\nabla, 11$, he remarks that S1mo's ancer is refleoted In his speeah in thit he says nothins but orlis repoltedly for his slavo - an axample of docorrm of amotions. ${ }^{2}$ It is a question that comes to the foro in any discursion of characterisation not only on Terenoe but in any of the kinds of 16 th century comedy that ultimately derive rrom him.

Anci if wo turn to sotual oomlo practice in Irenoe in the tenalasance, we find a breadth of poesibllities purallel to the theoretical ones. In thocry, a pallat should respect his master: in faot, in Godard's Les degzilseg, Haudolé almost rights his mater for

1

Herrlok, Comlo theory, p. 140 .

2

Robbins, Ixamstio Characteriration, p. 43. 
a oult of clothes. In theory, a soldler brass in fact, in

I'Eùine, Florimond does not behavo partioularly as a soldier at 21. Our 20 th century Ldeas about "des parsonnages fixes, stéréotypea", should perhags be aodifled. The set types reserable the meskeswhich in any case Renalosanoe sctors in many cases wore: and It 18 olear, for Instenoe frop Profeasor 18 fooll's work, that the masks of the cormedie dell'arte plavers mere no hindrance to variety - Indeod, in the hands of these particular highly exporienoed and tochntoally accomplished aotors, they were rather an ald. J1inlarly, in Fanalizance comedy, when the sudfence saw sn old man, a youns lover, a soldier, they expected cortain thinga. But these thinge vere only a basis, a foundation upon whloh flrot the suthor and then the actor was free to make his om varlations? the relationehlp between otaje and auditorlum was rather helped than hindered by the convention.

The question of docomun of ohargoter comes to the fore In the mixed genres. Dlautua' Niphitruo, the first "tragl-comedy", Whs so oalled for reasons of decoutus. Gods belons properly to tragedy, where they havo certain norms of behaviour. If, as here, they are found in comedy, behaving and speaking like the normal midile-class fleures of comody, then a reason of decorum is called into existence for oalling the play a tragi-comedy. So, too, in Gamier's 3radamante. Socording to the 
principles of docarum, a pal gdin of Charlamazne's oourt and his \%1fe ought to bohave and speak with proper dignity. Instexd, Mymon and Boatrix are in a traj-oomedy with a lot which is structurally very like that of a Renalss nnoe comedy, and they behavo like nomal riddlo-olsss people in such a coredy. There results the curious spectacle of Charlemegne's court comins forcibly down to earth without the justifleation of the Iuclanic sookery of the gods whioh was Flautus'.

The definftion of "stook" oharactere, then, is a delleate one." Charaotare like the bragsert or the young lover are rocosnisable from play to play; their social sroupings are generally the sames yet in a number of rajs $1 t$ would bo wron to regard them anly as a serles of types. Plautus, In the prolozue to the Captirl (11. 57 ff.) bossts that his play is unusual in not containing characters such as the perjured olave donler, the pril

I The stock aharcoters are Alscuased in B. R1 gal's "Les pereonnages conventionnels dens les oomédies du XVIe sibele", chapter 1 in his De Jodelle à Jollère, Paris, 1911 (also in Eavue d'histolre litterafre de la granoe, IV (1897), 167-79. On the brasgurt, ef. aspeolally 0. Feot, Der lles Glorlosus in der Iranzöslsohen Comodle

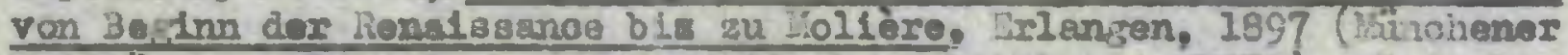
Beltrige zur Romanisohan und ngliechen Phllologle, XIII) i D.C. Boughner,

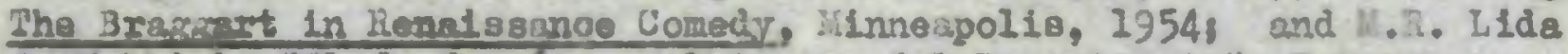

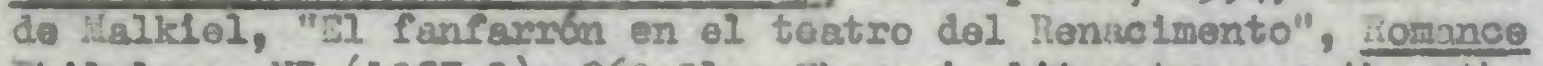
Fhiloloxy, iI (1957-8), 263-91. There 1s 11tersture on the other types of Renalsaunoe comodys of. for example C. Dletschy, Dlo "Damo d'intriare"

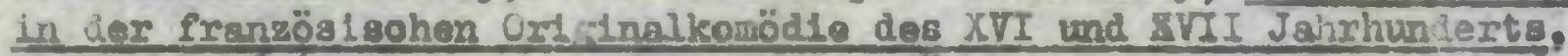

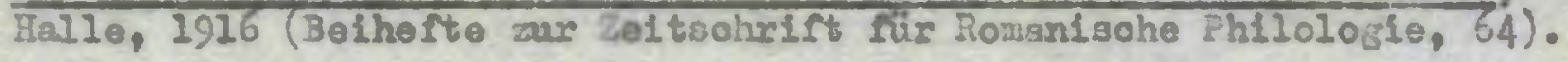


courtesan, or the brassart warrior, whloh are cocmon in his other pless. ${ }^{1}$ The Renalsoance authors, however, do not avoid types; how, preolsely, do they use them?

Nearly elways, the stook charioters are used as a basis for varlation. The old $\operatorname{man}$ in love, the timld horolne, and so on, are all certainly foundragain and again, but it is rare to find any on of them unolaborated, that is whthout the acidition of some Pesture or other which makes the oharaoter in question more than a mare examplo of the type. 19th sentury Molière oritios thought it Imortant - as did Lolière's oontemporaries - that charuoters should be universal, typleal of the human rsoe as a whole. But this oemnot be done literally. Ireme domands somothing more than a aherzeter so general, or than a simple types and in these plays nearly aleays the stoak aharaoters are used as a basis for variation: ruocingtion by the audience lo assumed, so that upon a famillar "type" may be bullt ug an indivicul ohersoter for use whin the play in question. Thus, Josse in ten uabahis is an "old man in lore"; but in act $V$ he is given oertain "brosgart" charsoterisatios whioh make hla something more than the atock char cter.

On the other hand, the oharadters are never very profolind.

1 C1ted by G.:. Duckrorth, the nature of riogan oamedr. Frinceton, 1952, p. 236. 
Severin in Los esorite 15 perheips the neareat approach in these plays to the minute exploration of a folble whioh we find in nollàre: a niser to whom lollare in fact owed aome foctures of his L'argre. Usually, tho oharsoters are developed enough to hold the audionce's attentlon, but not deeply enough orer to maico charaoter more important and si nifloant thnn plot. ${ }^{1}$ soldom, too, does a charioter develop in the oourze of a plays the abbe Lujine in Jodello's play to the only example I have found, who at the beglnnin of the play, sooording to Messire Jean, does not think enough of the future to guard afeinst misfortune $(I, 11) 3$ in the midale shows himaelf quite urable to think of a solution (II, iv III, 11; IV, 11; IV, IV); and st the snd shows hinself prectical both in thinging of a solution $(T, 1)$ and in oarryin: it out $(\nabla, 11)$. Derelopment was not expected of characters in comedy. cuintilian

IIf the evaluation of a plav is in question, other frotors must be oonsidered than the mere rolative 1mportance in it of "oumedie d'Intrigue" and "oomele do carsctere". The two mast be lintegrated. Chasles gave eicosive importince to that relation when he wrotes "Ia o nódle d'intrizue, qul se pleft à exolter la ourlosité et aे autisfairo I'Lmajlnation, recherohe les aventures, los surprises du hasard; elle peint l'imbrojl10 des évónemento, I'limpréne de la v1o extérleure, tout ce quil ne dépend pas de l'boinere, tout oe qui, par l'llluston ou 1'équiroque, trouble l'Intell1 jenoe ... La comédle de caractèro of fro un autre speotacle aux hormes, qu'elle suppose nés llbres et ralsonnables ... Son objet, quf ast l'étude, 1 s connalssance et la pointure de l'humanité, l'élève 0110-mône au dozté le plus haut de la ilttereture." (La cosáale .... p. 213-4). 
had sald that comedy resembled othos, or the set definition of a flxed personality, as distinct from trajedy which resembled patbos, a mood or phase of feeling. ?

It would be wron to sugsest too many qualitles for these plays 3 and it mas be a fault In them, conslderod as a group, that their oharacters are in fact not profound. To admire Twolfth a 1 ht For tho dopth of Ifalpolio's character as well as for the suppleness of the plot or the boauty of the lenguage; we adrifat the punuchus 1:2 the same way. ven in the best of these plays - L'zuime, He日 Qontens Las ranoneurs - thou tho characterisation mo be ald ful 1t very soidan ahows us any oharcoter in deptls, a fault that Profossor Lavton blemes on the excessivaly bookish quality of the initation in them. ${ }^{2}$ The most profound is probsbly Severin in Les esprits. This miser soes through decelts and misfortunes, his beloved troasure has been stolen: and then (IV, 111) he 18 sble to realise that his miserliness has in frot been an offenoe to himselfs

Fan un mosmo jour j'ax pordu deux mille escuz, j'as esté desnyalisé d'un ztiby, trompé par rrantin et deshonoré par Urbaln, lo fapon que

1 Cf. H.C. Bradbrook, the geonth and atructure of slizabethen comedy, London; $1955,8.43$. 2 "La ourvivanoe des porsonnages terentiens", pp. 93-4. 
Jo $n^{\prime}$ atten plus que la mort. O fortune, que tu es cruello, quand tu dellbòres faire mal ¿ queloun! Je n'ay jamalo offenoé que moy-mesme. 1

But hovever this may be, it is certainly apparent that in the hands of ak1lful author, the stook characters provide not a mere Punch and Judy show w1th unverying choraters, but an griertsinbent in which variatian upon the famlllax fl gures serves to ring tho ahanjes upon the wany relationships possible. The variation of each charicter is done with the ensemble of all the rest in aind.

A good example is Josse in Grérin's Les eabahla. We sain that ho 18 the "old man in love" who in act $V$ is given sowe "brasgart" oharacteristics. But there is alreqdy a brassart in the plav, Fanthaleones and he for hls part, oompered with the bragsarts in later plays, is greatly toned down. ${ }^{2}$ whoh of the last

\section{1} Areien thâtre fr neale, T, p. 266.

2

Pantalone in the Itallan plays is of course not usually a brassart; he is properly a mymifloo, an alaerly citizen (of. Allardyee N1ooll, the orla of liarleouln, eap. pp. 44-55). Thon he becomes a serenading lover, as ho 18 in Les eabahie, this 18 only as a varlation on his normal charroter, not as a replacoment for $1 t$. It appears that Gretin did not know, or deliberately lemored, the characteristics of Pantalone in Italy. Cf. R.C.D. Perman, "The influenoe of the corimedia dell'arte on the Prench thestro before 1640", Mrenoh 3tudiea, Ix (1955), D. 295. 
act is bullt upon these two oharecters and the inter-relet1onship of their two different kinas of brasgado. "Brajgarto" are alsc used in this way in Les desoulsez, where the rezular stook charceter, Prouventard, 1s falrly standerd, but where he is put side by side जIth a valet given certain "brasourt" characteristios (Hudole). In Lea Nozpolitaines, a stock "timia herolne" (V1rginio) is used wiale by sleo with a supposed Fldow and her mother, Anjelique, who is not s Btook oharactor. In Les contens, the entranetteuse Françoise 1s dereloped by oupposed ploty, played off arginst the real plety of Genovisve's mother, Loulse.

In short, to uso an:fook charicter as such, whout devolopment, is to trost him only as an individual, with very limitod. raferenoe to those around $\mathrm{hl}$, and is therefore sultable only for ocmparatively undevoloped drame. These plsys, on the other hand, are bullt up on the relationship between all the charactera; and for this, It is necessary that a stock ohsricter, if uoed at all, should bo modiffed to gult the druatio situations envi3aged. and In fact, we find that a stock ohartoter pure and stmple is a rarity in these plays. I Giordeno Brwno has a coment which 13 to the point

1 is tuatene is the earliest of the oomodies and so a speolal case. Guillaume is typloel of the ooen of the farces Eugtine is a mal: doveloped exanple of the pleasure-seeklns churchman of the faroe; out naltiar of the two soldiers is typloal of the brawsart in any source available to Jodolle. liost of tho plav's aharacters seem... 
on his own woe of stock charaotexs in II Candelsio, and which is entirely true for the Brenoh comedles:

Son tré materlo principuli intessute in sleme nela presanto comedia i' arar as Bonifa [010] l'alohimia di Burtholomeo et la pedantaria di Tímphurlo. Peré per la oojnition distinta de sussett1, resston delliondine, et evidenza dell'artiflolos: testura kapportiano prlas de per lui l'Instnido anante, seconito il sordido avaro. Terzo 11 gorfo pedante, Decuall l'insipldo non é senzis goffaria, et sordidezzs. Il sordido á pirimente insipldo et foffo, it 11 joffo non है men oordido ot Insipldo ohe goffo.?

Fone of the camedies spotlights ane bingle cheructer at the expense of the othors. It is seldom even posalble to say that one ohrrater is more important than the others: indeed, the very titles of nearly all the ocmedies are in the plurel. Les eobnhis, Les esprits, Lee ranon uns. The plot-structure is al ways constructod on s roup, as with the cormedia dell'axte, and as wh Terence, whoreas lollorre, for instance, following Cornelile, often focussed his plots on a Blngle characters L'crare, Lo mideoin malgre lui, Le malade Imsiningire.

... to have an Impression of nomoss, and as a group, they can certainly not be set within any single comic tradition.

1 Qlordano Bruno, Candolaio comede del 3rmo Noleno, Paris, 2502, f. ã 111 . 
As examples, I shall discuss four types: the old man In love, the servant, the brassart soldier, and the young heroine. The old man in love is one of the simplest. He appears in Josse In Les esbahis and Honsieur in La reconnue. Josse believes his Tife is dead, and he wishes to marry Madalene; he his a couch and a cold, but otherwise believes himself vigorous. This migt be the end of his character; but Grérin has widened the canvas by the comic contrast with another (similarly unconventional) bragsart type. Monsieur has the aore complex aim of marrying Antoinette off to his clerk to serve his own ends, and the interest of his character lies not only in his being an "old man in love", but in the considerable amount of ingenuity he is foroed to deploy tomide those ends.

The servant is a new creation of Renalssance comedy. He is not found as such in perence of Plautus, al though certain features of the Roman slave and paresite survive in him. ${ }^{1}$ Ee is part of the same process of 16 th centuiy modernisation of comedy which resulted in the substitution of European proper numes for Graeco-Roman ones, and of Italian and French marriage customs and problems for Roman ones. The Roman slave was bound to obey his

I Cf. G. D. Duckworth, the nature of Roman comedy, Pxinceton, 1952, pp. 249-53 and 265-7 respectively. 
master, and wht foar is beatin; if he did not. The henulos noe servant, however, 18 not bound in the same way, whother he 18 called Yalet, sorviteur, or laque1s. He is based upon somathing in l6th century sosiety which had no preclse equivalent in tho Roman.

Sorvants in those plays are nover uaed exoept in confunction with their masters ss ons of a palr. There is no suoh t?ing as a "sorvant" typo 1solatod in a play, lookins for a job. Whether in the social context of corrylus out orders for his master, or In other drumatic torts, the servant is never seen as anythins other then foll to a moter. He may be a foul and tha mater self-possessed (ifaudolé and Cl1vier in Los dosculsez); or tho reverse (Gogter and Don Deghos in Les Nogpolitalnos). He may talk to the audlonce: about his master (Antolno in Les esbahls, Messire Jean in I'Durene). Or he mey express ldeas that balanoe his nistor's (ant1-hero1am, or ant1-Petrarohan love). No ono detall (auch as anti-horolom) is common to all these servants tholr profal standins and their balanclns against their aceters are the only constint festures.

Coce these prinolples of the novelty of the role end Its function are gresped, the almost infinite variety of the sarvants In these plavs mike sense. Some mock their masters (Gagter in Les Ieapolitaines), some seive thom faithrully (Antolne in Les contenn). Some axe noral and seriougminded (Flnet in Lea escollore), wout are 
oynioal. Ind so on. The servent flgure is in fact probebly the role in which the teohnique of vurlation upon a stook charcater Is best applled.

Amon; all the different croctions, the two most

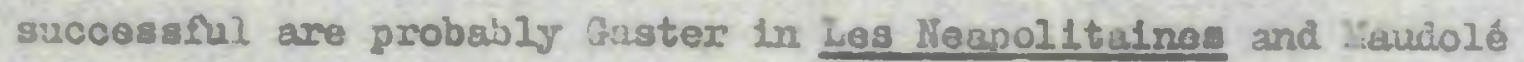
In Lea desoulaes. Gaster is a development of the Gnatho of Terenos's Duruch. In a fine sollloquy (I, 1V), he proclaims his polloys to attach himsolf to a mater and got as moch out of hin as possible. He is a mâuerean with no compunotlons sbout it a lively oynio, drawn ith much verve and verbal riohness. Heudols is the best thing about les despulsez, and an orictnal creation by Godord. ${ }^{2}$ Ho is a 5001 as well as a valet timia, but ewaugering when he is in his master's olothes ("Je pompe, jo morgue, je brave") - until he 18 attakked. He cannot oven weat h1s master's clothes proparty (III, 1), while he quite forgets himsilf in thinkln about the oomine banuet in $\nabla, \gamma$. Hia urassing and hla folly, howevor, nake him a flsure of fun him elf, so that the cannot be 80 moch an intermeliary betmeen the eudience and the grinaipel oharacters as soma of the other servants are. Thit function is performed in this play by Vaduplé, Prouventard's Izquale.

I Nelther he, nor, Prourunterd, against whom ho ls set, appears in irlosto's I Suppositi. whioh is the model for Los desanisez. 
It 18 done mostly by mozns of asides: of Vadug $1 e^{\prime}$ s 30 speeches exactly half are asides, ${ }^{1}$ while in the othor plars, such asices as there are are nearly always in the mouth of servant3.

To have seen that one of the servant's funotions is to serve os a counterbalanoe, in the audience's eyes, to his imster's 1dess. This epplies in pextloular to two kinds of ldews uplifted Petrarohar sentinents in love, and valour in combat. The servant regularly expresses hls nore down-to-earth views on love, and hlo Freater care for his oin ain, rospeotively. Thus, in Les comiveux. I, 11, F1ledelfe expreasea his love for Flourdelys:

mals quoy? gui est celuy qui no connolt, les forces d'amour? Gut ne connolt qu'1l est avougle, jeune et rolose, sans loy et sens ralson? C'ost par luy que jo n'ey non plus de repos que si j'avols le vif argant soubs les pleds.

while in soene iv his vilat Gillet is overheardi

Treyament to soroy bion un frand sot, pendant que non malstre demeine une vie anoureuse, s1 Lie part je ne me jettola susal our l'anour: non polnt de la sorte qu'11 fait, oar 11 est de ces arloureux transis, qui ne s'amueant qu' ${ }^{2}$ uns, et sont deux ou trols ans i lanterner, sans qu' é la fin 118 viennent au polnot.

Bontface's cowardliness in Ls troscrtèro, IV, $v$, 1s typloal:

114 are esides; 14 are ireot spech 2 contain both. 
Car, quand j'al ouy ce beau mesnage, Alnsi qu'un horme de courage J'ol saibré le grenter au foln.

Like the Bervants, the brassart soldiers differ cons1derably from esch other, perhaps beasuse of the Widely differins sources used. Morimond and smoult in L'Nursme axe the first exsmples in late, oring more to Plautus than to Itallan sodels. But they are aore than milites Bloriosi. Amsult, the irasatble Gascon, is the more developod of the two, but even he oan hirdily be coxpared to Pleutus' Pyrgopolymioes.

\section{Inat. j'en rante tous los oleur 31 to ne fais tomber on bas Tant de jambos at tant do bres Que paris on sora psive. (III, 1)}

All this is morely a pert of a fuller character ( he is a Gascon, a jood soldier, a faith ful follower of plorinond, and a scholar as well), we laugh, but only temporarily. In gensral, Jodelle uses these characters, to pralse, not to rook, the profession of arms, while there is no quastion of tho boast being exposed as an empty boast, as in plautus or in later french ouredy. Althougd Hessirg Jean says of thest

Sont de coux, dont l'un vend a terre, L'autre un moulin à vent ohorauche, (IV, iv) 
they are in frot takan quite seriously.

The naxt braggert, Penthaieone in Grivin's Les esbahis, 1e sloo untypicel. As we have seen, he is not the equivalent of the Italtar Pantalone. Dr. Perman calls hia a "young fop". He sings, in Itallan, ${ }^{1}$ to his lute, declares hinself in lovo, but doea little about it. Tro passages link hia with the brasgurt tralition:

\section{Vous lo verres tentost vantor, Tantost elover ses beaur fricts ... (II, iii)}

and ect $Y$, where he goes through the standard procese of bouts, threste and exposure then Jultion calls his oluff and forces bla to retrest.

These two passagoe axo scarcely sufficient to make him e: fuil and succesaful oharacter. His whole role, in fact, is handed with a costein gucherie: he appecrs trice ondy, his role is poripherel to the wain plot, he wixos confusingly the poles of Petraxchan lover and soldier, has vory name is insppropriato to gither rolo. In V, iv, his attorpted intesvention ("Flecser Gerazd,

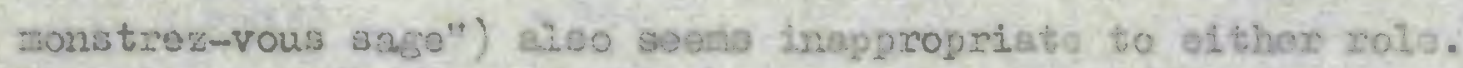
The brasgart soldier begins to be a recomisable

1 Mot macuranio French-Italian, as D.C. Boughner states (The 3rantraxt in Renalesnace Gonedy, p. 126). 
type in French ilenaissande comedy with "Lo capitaine" in Bellogu's Le reconnue. 2 The othera in the plays we are conslooring are Don Dioghos in Les Fespolitaines, Fodomont in Los oontens, Prouventard in Los dosguisez, and Standele in lemencewt, One feature only is conotant to all of thoms the sap between what this brasjart soldier bossts and what he 18 . This gap is usually made apparent by a threefold process of bosots, thrests, and exposure. Thus, In Les deserisez, II, 1, Prouventard bossts in a standard ferm of rab:

J'al falt connulstio ma valliance Au pass de Flandre, ou j'ay mis Cent fois à sac les ennemlo...

He threatans Grógolre:

31 vous ne mo render lo mlen, Jo $10 x^{\prime}$ auray bien par justice. Il $n$ 'est ohose que je ne puisse. Par 10 ang, lo ventro et la megrt!

Vous vous ropentirez du tort Que vous me falstes. (II, IV)

But soon he sees a man with a sword:

1 He is numod in the dramatis personse as "Le oppltaine lodomont"; but in fact his speeohes merely bear the ho sding "Ise copltalne" and he 1 is never actually named in the play. In $V, 17$, llaistre Jehan says he "tranche là du Rodomont" as though this were tet his narse. 
C'ost de le part pouthestre aussi

Du alre Grejoire...

Lials jo les empescheray blen

Do the tenir et mo surprendre,

St deussé-je la fulte prondre.

Kais s'1ls viennent pour mo frapper,

Par où we pourray-je eschepper? (III, ק)

It may be fighting thit is at stake (s rourentard) or it may be lovo (Dleghos). In any cage the maln dramatio funotion of these oaptains is to create a gag botween what 18 clalmod atcil what is performed.

Seen in this 1ight, their stonifloance in the dramatic structure emerges. The ilfferenoe between what is claimed and what is performod 13, aftex all, one of the main structural prinoiples upon which Renaiseance comedy ls bullt. Wo might compare the moral siturtions the actual laok of virtue in these playe coupled with concern for the outward appearance of it. The braggurts have tholx oim epplication of 1t, sometimes simple, and sometimes noro dereloped as in Les dessulsez whero a valet (haudolé) brage and is get asainst the brassart soldier proper.

It may be surprising, in viow of the evident cowardiness of the captains, that they are readily accepted into society. The craven prourantard is respeoted and indeod feared by Grósole, and is twice offered an advantageous marriage. 
Rodomont in ien contens is offered one as well, but refuses; Dleghos is sumsoned off to a good marriage at homes the captaln In ia reconnue is a highly respected aember of the king's forces, who at the end is fiven a spare niece and a job. (Santhaleone is an exception in this respoot so in others.) They moy all be exposed as cowards, but Instead of belng chased. off the stage at the end, they are all given a consolation prize of some sort. This may be scceptable as part of the required "happy ending", but in Ia raconnue at lociet loads to a dremstio inconsistency: the caitain's gab, considered as a rerbal exercise and entertalnment, is as good as any that will be found In these comedies yet it is quite irrelevant both to the action of the play and to h1s lonown reelly valorous oharacter. It 18 the firgt part of the "boasts, tireats, exposure" pattern, well executed but 1solated and quite unintegrated. Dramatically, it Is odd that a charroter should boast emptily and be mocked - end yet should be acceptel. In the end. Plautus' Fyrgopolymices is not accepted in this way. It may be that the high esteen in whioh the profession of arias was held in the 16th century socounts for 1t: the bresgart may personally be a fool and a coward, but his profession is an honourable one.

The haroines, unlike the servants and oaptains, are nearly all of a type. Possibly played by boys and therefore by less 
experlenced actors, tholr parts ans genarally amall. In Les asbahie, Ledalène appears anly in II, $\nabla 1$ and IV, $\nabla$, is timid, lamenting oreature. In La reoonme, Antoinette appears only in I, 111 and IV, 1-11. Sho is a devout huguenot, w1th little w1I of hox own, and certainly not in control of the marital intrigues golng on around her. The heroines of Les egprette do not appear, or at least speak, at all, the only femsle parts being a mature wife and mother, and a mald. ${ }^{1}$ In Les Nespolltalnes, Angolique appears only in III, Vi-VI11, and IV, 11. Nevertheles, the is oertainly not timid; but then sho is supposed to bo a ridow and Is therefore not the typical youns herolne. That role lo fllled by VIrginte, whose one appearance in the play (III, VIII-1X) shows

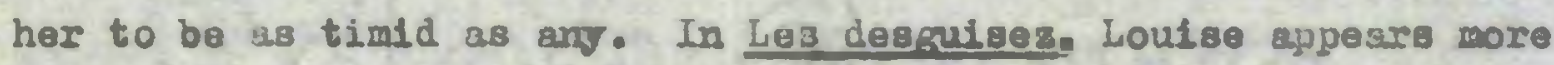
ofter than is usual (II, 111; III, $\nabla$ and $1 x\}$ IV, 1 and 111, $V$, IV and $v$ ), but she 18 extraordinarily timid. She breathes no word of protest at her father's cosmand, either to him or to her mald; she leaves Olivier Imadiately whon teo reveals his disguises her fear for her reputation is obsessive. In Les oomivaux,

1

The absance of the three herolnes, around whom the plot revolves, certainly crestes an odd Impression. But as the ploy 18 an adaptation from the Itallan, their absenoe may bo accourated for by Italian rather than rench stag practice. 
Reatitue appeare only in I, 1, while Fleurdelys does not appear at all. Lost of the exposition is put into Rest1tue's wouth in this one oarly apperranoe, thus combinine the domands of the exposition ith a short appearanca of the herolne.

The herolnes, then, are very similar - mere 80 perhaps than any other types to be found in these plays. Whereas tho servants wero different from play to play, these axs usually expotly what one expects. A set pleoe that oocurs egain and ajuin is the lament by the herolne on har unfortunate jesition, of whioh a typioal example is this from Les esbahis $^{2}$

\section{HADALIBSE, seuro}

Hé! 1a Meur de mos Jounes ans S'en lramelle alnol perduo, Lt la joje tant attendue Lise à nesut, par la contrainte D'une trop enviouse oratnte? C'est or' que je sen la puissance D'arcours mis, las! mon impulssance, Les inenaces et la promesse in' ont romis on telle deatresse, (u'ores que je veullle une chose, Toutesfols lihonneur y oppose...

One might suppose that this eimilsity is due to the laok of Independence which unmarried daughters had, as a matter of historioal faot, in the remaissance. Only one herfolne is mare 
determined: Gressette in Les eseollers, who, Independent or not, sims to follow her oholoe by one meansoor another.

It would be tiresome to examine all the charsoters

In ell these plays. Besldes the old man in Iove, the servant, the brasgart and the heroine, two of the most important ara the young linmorato and the parent conoerned for his ohild's welfare. Sone few charaotere do not belone to a type. One 18 the Gentilhomme in Les eabahis, a sensuralist whose gyinfons contrast with his frlend the Adrocat's 1deallem ad who reminds us of Tirsis in the first soene of Helltes and Anjollque in Les Nespolitaines. a supposed widor with a blager part in the play than any horoine In these ocmedies.

Character and plot are necesearily olosely linmod, and the are olosely, the more ooherent the whole play. Les contens and I' untne ahleve the olosest syntheals of the two, in the semee that they depend only on the working out of the factors of situation and character glven us in the exposition. In LI Sugene, the abo's lack of practloultty and Hblène's lack of responee to Florimond lod to all the trouble in the pest, Culllaune's aimplicity made it posalble, and Florimond's anger bringa it to a head. Wvery other Frenoh Ronalssunce comody before ksllte, without exception, uses at least one deus ex inaching.

Such a use of types 18 oomparatively sophlaticated. 
Admittedly it needs a finor dramatist than we are dealing with bere to make out of a type a rull character, but at the same time the Infertor effeot is avolded of reoognition of the type and nothing more. In noarly every oase, the suthor has indiocted a type, so that the audience lonows approximately what to expect; and then he has played upon this lenowledge on thelr past by creating a varlation upon that bype. The technlque is one noro use of the theatrical relationship of the author and his audiance. Among the mpgt suocesaful achievements are Josse in Ies esbahis, the brascart old man in love; Maudole, the foollsh valot in leg

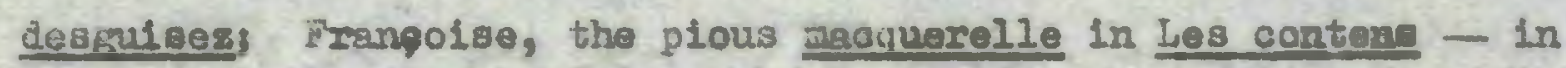
each case the suocess is due to the combination of something expected with something now.

\section{Spoeah.}

The verbsl style of comedy.

Whon Prangoia d'siboise, unier his pseudonym Thlermi

de Timoflle, preised his om comedy Les Noavolitaines, he emphasised the verbel styles

on oesting on trouvera un frangols aussi pur et correot qu'il s'on solt vou depuls que nostre lansue est nontée à ce co:able, à l'alde de tant de laborleux et subtils esprits qui $y$ ont ohacun contribué de lour trarail et dilligence pour la rendre polie et perfalcte. La lecture et la conferance en rendront seur teamoignage, outre 
la gentillesse de l'invention, le bel order, 1a diversité du suioject, les seges dlecours, les bons enselinewers, sentenoes, cramples et proverbes, les faceties et sornettes dont - lle est seméc le toutos parts ...1

Ixcept for the vazue "La jentillesse de l'invention, le bel ordre, I. diversite du subjoct", ell these virtues refer to the verbel style. Porhaps this is not surpaising in a man who wrote a great dest and published only ons play. But it is a common arghrois in other writers toos Larivoy in his lonj Iplstre to d' Ambolse discusses only the ethics of comedy and its lansuage - not its plot, 1ts characteribation, or 1ta stoging. Miss 3radibxook says that this sam emphusis 18 found in Enjland toos "The development of Blizabethan comedy is very larsely the development of its lanjuage"; and wo exainine the oritioal evolution of oomic mitins 18 ... to exanlne the goneril theory of rhotorio as applied to poetry". "

For vorbal style as well as for charsoterisation, ldeas of dooorum aro asain all-important. A character must speak, not only behave, as his onaracter and situation demanc. La Fresnayo's disoussion of decorum in comedy is dominated by the 1dea of spoechs

\section{Les Moanolitaines, prefics to Charles, duc de Luxembourg,} Anclen thst5re frangelg, VII, p. 239.

2 H.C. Bradbrook, Bllzabethar comadr, pp. 49 and 32. 
Un doux parler est propre sux homes tels que toy [Ragot]; Aux ho mbes furieux paroles furleuses, Lasoives aux lascifs, et aux joyeux joyuses; Lit lo as,o propos et lo grave dlsoours A quilconque a passé de jeunesse le oourb. Car Nature prenier dedans nous a formée L'Impression de tout pour lo rendre exprinse Par le parler après ....

Il faut que la personne ì propos discourante Suive sa passion pour estre bien disante. ${ }^{1}$

The plays do in faot follo: these 1deas. In Leb contens, III, Lx, the oervants antoine and Ferzotte here a serles of Indecent axchanjes ouitable for the oharacter of servants, while In the same play, V, 11, Busllo and Conerlove have "love-cuet" couched in the loftlest terms. The tro take place at the eame rindow of the same house, and are olearly moant to highlight oach other. In auoh osses, the roosbulury, syntax and imagery vary Greatly, though there is no equiralent to Shakespeare's use of a mixture of verse and prose, or 3odel's use of different tres for different charsoters, for the radium remains the samethisoushout each of these plays without expeption. The bresgarts, the older generation, the young lovers, all have their individual kinds of speech. The rerbal difference betwien servant and mastar is one of the nost important and clearly defined, since it is one of the

\footnotetext{
2 Lawton, IIandbook, p. 104 . quoted from
} 
clearest of sooirl dlatinctions. Here are 01ifier and Naudolé In Les despalser: the materi in love expresses his misery with a typical invocation ("O potit dicutelet allé"); Godard makes the servant first express his interest in food, agi is guite conventional, but then plays rith the master-bervant convention by making liaudole adopt the opposite view:

Noudole, J'al lo foy et la rate esmue, Tant 11 m's fallu chominer Pour vous dire qu'on va disner Et qu'on s'est desjà mis à table.

Olivier: Holas!

Halolsi cuel not espourantablo! ifl se faut-1I ains 1 faohor Quant o'est gu'on parle de masoher? Dopula un temps sans oesse 11 sto Et contrefeit toujcurs la trosne De quelque pourcesen man-brusló.

Olivier: 0 petit dieutelet siles

Haudole: Il mo faut on tristerse mottres "Si joyeur ou triste obt lo malstre, "Ie valet lo doit estrocamoel." Aht helas! que j'ay de souvi, J'ennuy, de peine et fascherie! que ara pressure en est marrie!

Oliviers o petit dieutelet allé: Moudclé: Melas!

011vier: $\quad$ Es! qu'a non Madols? ...

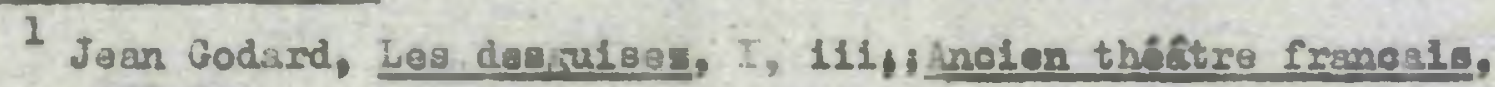
VII, pp. 348-9. 
The frequent proverbs and popular sayings like Saudolg's "S1 joyeux ou triote est le msiatre, / Le ralet doit l'estro ausi" above, correspand in a sensa to the sententias of Renaicsance tragredy. These partioul ar two Iines even share the typozrahical convention of specialy inserted sulllemets to maris them. In trasody, the sententias are put lato the nouths of kinge and axistoorats, and express with remariesblo oons tonoy throughout the century scmo aspeot of the 3tole philos ophy supposed to be proper to people of that rank. In oomedy, the proverbs and saylngs express the wladom supposed to be proper to the characters of comedy, namely the jourgeols anci the serving olass lemediately bohind ther. As d'Ambolso says, Les Mespolitalnes has a largo number of thom. So heo les oontens; ourlously, when the pley was ro-1ssued so log dogruises In 1626, the titlo-page expresily stated that the new odition ccntalned "L'esplication den Proverbes et nots dif lcilea", as though proveros as such prosented great afficulty. Larivey, too adapts into a rery easy and natural French the Italian proverbs and saylnis of hls orifinals; whlle sil the comdies of the earlier generation include that in plenty, 2.3 well. Hans of the same ohrases reappear in play after play, pos3ibly somotimos so diroct sources. They are a kind of popular stomahouse providing matertal throughout all the Renaissance. Lison the many paraliels are: 
"falre ses ohoux gras" in Las osbahlo, Les contens and Los dearulsers" "La fortuno aldo aux amouroux" in Los egbahle reappearing as "Amour aido aur bardis" In Les desguisozs ${ }^{2}$ "hals qui est galloux qu'11 so frotte" In Les eseollers correponding to "Vous me sratter ou il me demange" In Les oorrlvaux ${ }^{3}$ "qu'll s'en torohe la boushe" or some varlant of the phrase in six plays at least.

The popular kind of lwasery is the most frequent in the plass, though none of the plays 1 as deliberstely or polintediy about the oonmon people as, for Instanoe, Dekker's The Shoomalears' Hol1day. The distribution of different kinds of 1magery in a play is alonifloant of the cuthar'g concsption of his subject, and of the audience it was Intended for. Ironah Renalssance comedles show four kinds of imageryz the popular imagery of proverbs and 3 imilar flgures of speeoh; isenoh hlatory and literatures Petracohan; and classical. 4 The roferences to nutive hlatory and 11terture are, for

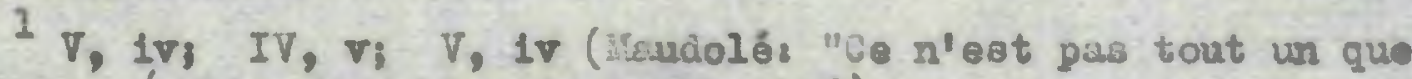
des ohowx, / Il y ura bien de laz erasse").

2 III, 111; III, V111.

3 IV, 1i, $v, 111$.

4 It would, of oourse, be possible to list the images in the lays socordin to tha type of the compare, as Dr. Spector has done in his edition of Les contens, po. xllx-11 (religion, the household, businass, animals, the body, anti-olerlcaliam, enti-feilnism, war, games) i but a list of this kind does not tell us much about the function of the 1mages. 
Instance, Rodomont's culling his sword Plumbergo in Les conten, or the frequent use of tho warl petelinges. In this breedth of Imagery they differ from other works by the sape authors. Grérin's L'Ollmpe and Gelodsorye use almost exclusively olassionl and letraxchan inszery, but his two plays inolude a ziols store of popular 1mages and turns of phrawe.

Those rioh forms of imagexy, the emblem and device, exe find tholr way into the plays. D' habolse, we know, was interested in them, tranilatins and oomenting on Paradin's book, and writing a Discourg ou traloté àes derises (Paris, 1620). Ind in his play - though it dates from many years earlier - the bracgart Dom Dieghos has his devisos:

Dieghos: Tu ve vols blon a ceste houre palsible et aimable, tellement que je te serable un petit ango, ou plustost un potit Cuplâonneau; $0^{\prime}$ est pourquoy fo porte en ma dovise uno abellie, areo ces mots: Brezia j mlel, voulant donner à entendre, par la Ileche et lo miel, guo je suis brave zuerrier et amoureux tout onse ble;

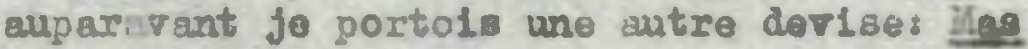
honra que vida.

Gaster: Proprement.

Dloghos: Je auls blen lors aussl furleux et torible, de sorte qu'1l $n^{\prime} y$ a al brave qui ne tremble devant moy cont pieds dans lo corps. As-tu jamalo veu polnct lo deu trars? ...

Gaster: Gul donc? Celuy qu'on dict le dieu des batallles? W'est-ce pas oestuy-là qui est pourtralct en uno modallie gue vous portiez an bonnet? 
Dieghos . C'est Iuy-mesne; me royls tout flct.

inother developed and frequent pletorlal imge is the potrarahan one of the lover as a ship in a storm, seaking a refuge - it is as It were a conetant picture, the roodcut to which the glay supplies desoriptive coment beneath. Here is sugustin in Leg

\section{Neapolitalings:}

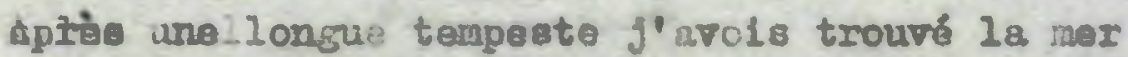
oalme trinquille pour l'esperance que je prins alux promesses de oeste servante [Bets], et on un Inotint lo vent furioux do jolousio $\mathrm{m}^{\prime}$ a reniso on toursentes puls le temps s'est rendu un peu plus asrain, le vent m'a donns en pouppe, qui me falt urigtr qu part tant deBlré....2

Surprisingly absent is tho use of jargons the jargon of tho pedant, of the doctor, or of any such specialised types. Desplte their plentiful axistence in the Italian modele arallable to Larivey and later playsrights, charaoters llke those hardly

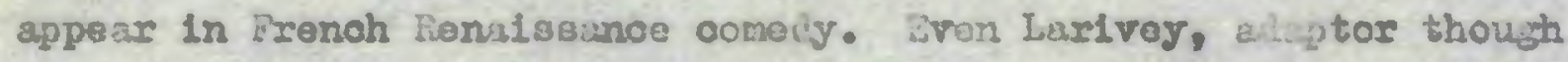
bo жथ, is comparatively sparin in his use of them. givno's II Cundelalo uses an extreme podant, Manfurio, but Turnèbe and d'Arbolse do not. The only pedint in the native comedy is Bonareius In Les rarunnarss. So that al though the speech certainly varies

$$
\begin{aligned}
& 1 \text { I, IiI. } \\
& { }^{2} \text { II, IV. }
\end{aligned}
$$


from oharacter to character, this partloular kind of exacreration 18 rare. The braserart seeme to concentrate within himseif all the need for exasjerition in those plays, and even he oan hardly be sald to use a jargon. Though his boasts may be grotesquely exasgerated, they are st1ll couched in culte normal vocabulary. ${ }^{1}$

The kinds of Ianguase that I have described ohange abruptly with plot-absuoturo. Les ranonnoure was stylistloally ent1rely in the I6th oentury tridition, but elite boglno somothing culte now for comedy: a style based on the prifcloux poetlc languaje of the early 17 th century, and in drena so far found only in some pastorgls and tragl-comedies. The imajery 10 no longer colourful and dom to eerth, but abstract. There are no servants to bring their masters down from their fancies anly one nurse, whose entirely different funotion is that of a confldante. The lanzuaz and imszery of every Renalsannce comody are rglated to a soc:al altuation and 1 ts practioal problems; Melite's lunguezo and lmagery aro related to

1

Robert Garapon, in his La funtalole verbalo à ne lo t.êêtre fruncais, Paxis, 1957, ch. III, comes to the sinilar conolusion thet jargon and "Santaisle verbale" are rare in Frenoh Renaloaunoe ocmedy. He sees Le Loyer's Nopholocoaugle as an exceptlon, where le Loyer's wodel Arletophanes hes prompted a numbar of overflowing toxrents of words, recalling not only Arlstophanes, but the farces of the time. 
otates of aind. The Imagery is that of the salons, subtle but comparatively oolourless, with the exception of Irasts's med scene, In which the imejery of the underworld is develojed at gxeat length and with strong effect.

\section{Verse and prose.}

The Plelade comedies olgniflcantly used the vohicle of the native French faroes, the octosyllable without alternate mosouline and feninine rhymos. Apart from the translatoro cherles Datlenne and Jean-Plerre de llesmes, the first to change this lo La Ta11lo, a fisure of transition in 80 many ways. His Les coreivaux is in prose, doubtloss following the model of Italy, where 80 many comedies had already been mitten thus. Le lie ronant is in prose also, although Arlosto's II Nerromante was in vorse. Les corrivaux is written in an easy stylo, always nowing and colloquial, with very few passazos in any klnd of corplox or elevated style. Iren the lover's set speech is dorn to earths

mals quoy? qui ost oeluy qui ne comoit les foroes $d^{\prime}$ smour? ul ne conrolt qu'il est aveugle, joune et volago, suns loy et sans raison? C'est par luy que je $n^{\prime}$ ay non plus de repos que 81 J'arols le vif argent soubs 108 pleds. It pour caste actuse, je n'ay fait que tracasser par toute 1a $v 1110 \ldots 1$ 
Compare Grévin's verglon of the same topos:

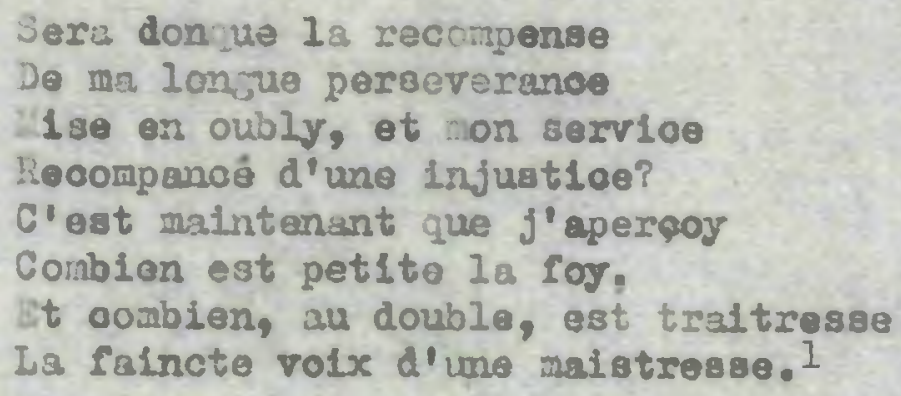

- a laront 54 lines lons, compared with la Tallle's nino lings of prose before the lover turns to practiosl measures. But La Taille is before his time in miting in prose. Balf after him, and Chappuis, st1ll use verse in thelr plave, und It is a whole new soneration, dating axactly from the arrivel in Franoe of the Italian players, that turns to prose as a modlum for

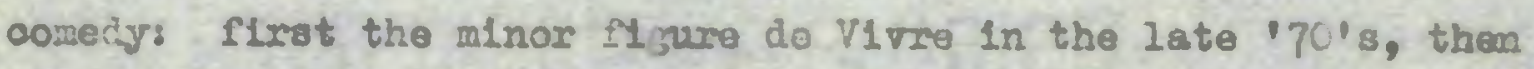
Larlvey, Tumèbe and d'Arbolse. Bruno's Il Candelato is in prose, Fomarls' Incelles too, and its trenslation Anrelicue. Los ramontiours. thoush forty years later, Bhares the same modium, as nell as sharins oinilar characteribation and subject-matter.

Porrin and Godard both return to verse for their plays. Perrin of course is turnine backe to faroe (and to Terenos) for his models, ant ming from tho Itallans Godard adspts a glay of hilosto's

1

Les esbahle, II, 1. 
which existed in a vorsion in verse as well as ano in prose.' Troterel, too, uses veraes the cotosyllable for Gillette, and surprisingly alexandrines for log corrivax. Cornellle turns to the aloxandrine, doubtless booause of its use in the tragl-comic and pastorsl gonres that jreshadowed his play.

It would bo true to $3 \mathrm{~s}$, then, that the faroes provided a rodel for the ootosyllebio metre of the Flsiade comedies, and the Itallang for the prose of the naxt ceneration. But these are listorical roasone. Is there any intringic merit in one fora rather then unother, in the octosyllable, the alexandrine, or prose?

Iienaissance theoriste and ploymights sald that there was. One sujgestion was that the more serious the subject-matter, the longer the line should be. Sobillet wites of the alexandrine:

Geste espeoe ost nolns frequente que les autres dous preoedentes [olgh- and ten-syllablo lines] ot ne so peut oroprement appliquer qu's choses fort reves, oones aussi au pols de l'aureillo se trouve pesante.?

But thls is of course an illusion. The test is an aurel one, and In actual delivery the longth of line makes very little difference. G1lbort Qadoffre wites in his Bongerd par lut-rhâme about similar

\footnotetext{
1 Cf. Arlosto, Opere Minorl, vol. II, Morence, 1857. 2 L'art poétique fringols. od. Galffe, p. 41.
} 
Ideas of Paul Lawnonier: "On reste confondu devint une telle mofoornulssance des atructures post1cues". and shows how the shortest Ines oan have the heavlegt effeot:

Coux qui sont sous lo resvell Du soleil

Coux qui habltent Niphate,

Ceux qui vont d'un boeuf surant Remaint

Les gras riveges d' 'uphrate.?

Another subsogtion was Laxivey's, a naturallistio 1dea before its times comedy deals with people of oomparatively low rank, such people do not speak in an elevato way, therefore comedy should be in prose rather than verse:

Cr, al jo n'ay voulu en ce peu, contre l'oplnion de beaucoup, obliser la rranchise de ma libert de parler la laverité de la loy de ces oritlques qui voullent que 18 Comodio solt un poëme subjeot au nombre ot mesure des vers ... jo l'ay falot [1.e., ha has written in prose] parce qu'll m's seriblé cquo le oorisun peuple, qui est le princlpal porscanage de la scène, ne s'astudle tant à agenoer 30 parolos qu'à publler son affection, qu'1l a plutost dicte cue pensbe.2

The very artifiolality of drama, of course - pextioulurly of the

1 Rongard oar lul-nene, Parls, 1960, pp. 85-6. The verse 13 from Ronsard' 3 ode ar tho d'Orleans.

2 Preface to Frangols d'Aubolse, hnclen thétre frausals, V, pp. 2-3. 
un-naturalistio Remeissanos drama - scotahes this idea from the start. Ind sinoe such things as the coares jests of the servants fit easily into verse, the theory cannot bo justified in practioal teris either. Howerer, in tho lenglsaanoe ocntext, it is evidently another atte:apt to achieve dooorum, to put the appropriate kind of speech into the wouth of the appropriate kind of person. Shalcespeare Lndeed followed the same prinoiple of deoorum in his use of veroe and proset in those tragedies where comlc passages appear in the mouth of lower-clas oharacters, those passages are in prose asainst a b ikfround of verse for the rest of the plays

Kacbeths To know in deed, 'twere best not know maself. (nookinz within) Tiake Duncan with thy monicielngt I would thou oould'at! (nter a Porter. Cnockin: within)

Porters Here's a linoolding indeed! If a rian were porter of hell-gate, he should have old turnine the key. (mookin :) nook, knook, knook. Who's there, i' the name of 3 eelsebub?

Effective $t$ ough this may be, it is of course not eesentlal to the theatre: Jonson' H lohealst is entirely in verse, from the opmplex rhatorio of 3 Ir Iplcure liamon to the rapld exohanjes and cursea of the arrival of the officers in aot $\nabla$.

Neverthelese, these theorler, combined with the exanglee of the verious aodels, orobably in fact determined the ocmic practice In Franoe. One may wonder only thy the universelly sdmirad model, 
Terenoe, with his hexameters, was not inftated in this respect from the vexy bezinning.

Monologres_and \&o1deg

The monolojues and agldes in these plays, like the prologues and epllosues, provide a relationshlp tith the aldionoe. They ray be compared with the chorus in tregedy, whion inherited from the Greaks and Sensos the function of representing, to some extent, the audietwo's or the common people's point of view. The o'sorus, composed of nom-aristocrats, cormenting on an action over whloh they had little or no poiter, proplded a link between the aharnoters in the play and the aullenoe. A rurther link existed in the soliloquy. Both, howevor, remined on the further alde of the boundary of 1llusion: in trajeoy, nelther ohorus nor sollloquy would contain any direct allusion to the aldience, or address it as "rous". Ssdécle In Les Julfres mey address Ishovah, but not the audionce.

In comedy, monologues and asldes have a oomparable but nore direct function. The aside, rase in tresody, is comion in the comedles, and by its very nature is a direot oonfldence made to the audlenoe unheard by the other oharacters. The sollloguy in tragody by 1 ts nature admits the audience's presenoe, but particularly the aside in comedy makes positive used of it, sometimes addreseing it direotly. 
Asides and monologues in, say, 19th contury melodrama, are used to stir the eudienoe's exotions; here the sppeal is rather Intellectual than enotlonal, but tha procedure is the sane.

In Les esbahis, Grévin uses nineteon nonolozues and fifteen asides or Groups of asiden - a large number for a not partloularly lonz pley. Some are used for exposition, but not tiresomely so. Only once does a speaker over speak directly to the audienoe (Julien in II, 111: "Vous le [Panthaleone] rerroz tantost vanter, / Tantost elever sas beawx falots") but there are quegtions and pirases such as "Ionsez quo ..." which are what wo call rhetorical. They are most remarkable for their guantity. There is not a single dialosue whioh is not Ranked or intercupted by a monologue or an 2side. A typloal grouplng is a monologre, followed by an aside, followed by a dialogue, thuse

Lo Gentilhommes (nonolo, $240:$ )

... Il feut sgavolr donner le tour

A ohicuns ot dieu spait ooment E11' font espargne de serment, rour jafour paslier leur deffalcte. (Aside:)

Kuis roicy venir ma tendrettes Je oroy qu'ell' est blen asseurée, A la roir tant dólibéróes II lo fault avolr à la chauldo.

Clama: Dleu vous gard, tonsleur.

Le Gent1Ihomen Dlou gard, Claude. 1 
Hany different combinations are possible, for instanoe, in the same play III, $\nabla$ bogins with a nonologue by Gerard, followed by a dialogue aside between Julien and lerion. The important point is that both monologue and esides are accepted as a more normal part of the dramatio structure than they geriarally aro today.

Los contens and Les licapolitaines havs typlosl srouplngs of the aame kind, but in theae plays it 18 more frequent to have a monologue followed by dialogue, without tho as1de. Les contens as a whole includes only four alides or groups of then. Typiosily, a dialogue will not begin or end without being ushered in or out by a monologre, thuss

$$
\begin{aligned}
& \text { Rodomont: He, mes anta, aver pitlé de moy! } \\
& \text { Sergent: Hous ne pourons. C'est trop prasohs! Sus, sus, } \\
& \text { zonons-le dessous } 108 \text { bras corian une marífo: } \\
& \text { Rodomonts } \mathrm{Ka} \text {, Hou, que je auls miserable! Au llou d'eller } \\
& \text { flancer ma mistresse, I'on me falt espouser } \\
& \text { whe prison! } \\
& \text { Baslle: (tho, inobserrod, has seen Rodomoni ostriod off) } \\
& \text { J'ay ou du plaisir pour plus de dix mille frans } \\
& \text { de rolr oe fondeur de naseanx } \$ 1 \text { mpesché au } \\
& \text { millieu de ces gergens .... }
\end{aligned}
$$

In jes jegoolitsins, Gastor has $81 \times$ monologues and takes part in alx dialogues; Log's five of each.

1 Les oontens, III, $11-111$. 
The fondness for asides and monologues is part of a whole style of acting in the Reneissance: an exesserated style in which this easily over-acted plece of dramatic convention is not out of place. In theory, they can be effective by their rarity. But in these comedies, they are so frequent that they must be accepted as part of a full convention: not a sudden effective exception, but part of the essence of the play.

The monologues fall into recognisable patterns, by their form and by their subject. Formally, thay stund at focal points of the plot: at the beginnins of scts or at points of tension or realisation. Thts in Les contens again, Thomas: monolosue about his determination to make Rodomont pay beitins act III. And astache's monolosue about his detachment from Genevieve is structurally importent because it leaves the way clear for Basile. Their subjects are regularly the same: to the lover's lament we may add the young girl's lament, the valet's cynical comments, and so on.

The asides represent one of the most exajgerated conventions of these plays. They 1mply, of course, that the character speaking is not heard by the others, and often indeed not even seen. Sometimes this leads to flat improbability. Here is the third scene of the third sat of Les corrivaux, in which four short monolosues are followed by three asides: 
Clauder Puls que jo ne voy plus personne on la rue 11 est tomps de falrs le sline quo f'al promls à Filadelfe.

Alizon Puls gue Claude et Tromin s'en sont allez, it faut que j'aille bafller I'asaignation à Euvertro.

Claude: J'sy desja ouvert l'hule de dexriere par où 11 s dojvent entres.

Alizon: Je vien tout a point de trouver nostre huys de derrtere devaroulllé par je ne aqay culu.

Claude: \&u'ost-ce çu j'oy parler derriere moy? Hi c'ost Alizan, coste vieille diablesse. Ue le diable face inaintonant une anatomie de sa cezvelles ollo me gastera tout.

Allzon Ne voyo-je pas là Claude? ito bon gró en aft ma vie, il me destourbera.

Clauder is faut-11 trouver fagon de m'an depeatrer ristamant. Vien ga, que fals-tu loy?

A print in the Reoveil Fossard, and an will painting copled from It (of. flg. 10 below) show an ovarhearing soene in setions "II capitan Cocodrillo" (1.e., Fabriglo de Eoxnaris) is shom bent double listening to a conversation, without any scenery or "props" to hide him. The artifiaial convention traglles an exasberated kind of ceting,

1 Iurnebe, ancious as orer to minirise the artificlality of his play, provldes a oart (or an "aurent") for Rodonont to hide bohind in I, $1 \nabla$, but this is quite orceptional and the matter is normsily left to the ectors, to inprovise with pechaps a "ruelle" betwoen two compartments. 
assoclated today more with melodrama than with oumedy.

The petterns of dellvory, then, fall naturally into

a Bnllnumber of recognised kindss prologues and epilogues, monologues, astdes - end, of course, normal dialogus. They are, of course, a convention. But there 18 moro variety and less stiffness in thelr use, partloularly in their many combinations, than there is in the corresponding conventlons of French Renalesance tragedys the openin ranologues, the choruses, the stichomythla, the numbers of aententire. Pracjecy achleves a cartain formality with thon, but too often st tho expense of stiffness, a fault whioh can seldom be lald at the door of the comic writers. 


\section{CURELUSION}

The comodles of Jodelle, Grévin, Bellew and La Taille are of a kind, shardnz oertain features of construction in such a way that they are unicule in the hlstory of oomedy. MII witien by students of the University of Parls within some ton years, they have a faully likeness. Thay blend the subject-matter of the native Benres with the forms of ciassical coredy in a way which is not found in any other 11 terature. Mor I indignation is absent, so is profound charsoterisation, but the peouliar blend that they have adopted gives them a Iiveliness that amply compensates. They are ouccessful entertalnment.

The later pleys too are suocesaful ontertalnment. But from Larivey onwards the Itallen comedles are taken as a new sodel, and more wholehoartedly, so that the peoullarly frenoh oharaoteristios of Las oontans or Los Neapolltainge are fower, found in varietles of speeoh and lagery rather thas in oharacters or plot. Las ramonneurg, as late as about 1624,18 mach nore French in every ways in 1to Ifvely style, 1ts reforences to Parls where it take place, its rench characters, its uoe of Prench faroe-actors - and it is regrettable that so lively a play should have been (as far as we kenow) the last of 1 ts kind, suppliunted only 
some five years later by the new comio style of Comnille.

The deoor for the plays sooms to recain oonst:unt throughout the Renalasanoe, with some alaborations - but not basic changes - around tho late $1570^{\prime} \mathrm{s}$. It conslsts, without exoeption, of a centril area supposed to be a olty street, nianked by a number of town houseb provided with doora and windows and some of whose interios are pratioable. The internal orldano of the pleys remains constant, and is supported by a certain amount of external, mostly pletorial evidenoes the farres show a primitive noutr 1 areas Serl10's "comic scens" shows a deoor of the letnd neoded (though more eleborate); the Itallans vary but in genoral erpport the patterns whilo wholot, In a déor such as that for Fotrou's Isea Menochmse, corresponde ertirely.

I have written it len;th about the conventions of the plays. These conventions, of plot-struoture, of character, and of spoeoh, ramain sanerally constant through elighty years, despite tho important andral of the Italiens ant thoir adoption as models, and despite the forty-your gap betwean Les llearolitaines and Les remonneurs. Trotore 1 and Codard, within that gre, show that the arie conventions continued to be acoepted. They are, of course, a means of relationshlp between author and cudience: in 
praotlos they mean that an euthor w1ll use the tochnigue of variation upon a norm. Brajgarts and valets are two accepted kinds of cheracters to mix the two, as Godard does in Los desculisez, is to oreate a now effect. Hnother form of Ielationohlp with the audionoe is dramatio lronss when, for instanoe, Messire Jean tells us that Mugène is growing careloss and wlll find hlmself in trouble - and the trouble then in fact arrives.

The oonstant recumence of conventions of course obstructs our 1des of originality, but that 1dea la 1rrelevent. Ily aim here has been to discover preolsely what conventichs were used, and to emphasis aiove ell the way in mioh rarlations upon them were carried out: to polnt out not unlformity, but variety, whlch 18 the assence of the plays. The principle of veriation has been well stated by Roland Baithoss

Structuraleatent, le sens no naft point par répétition mals par différenoe, en sorte qu'un termo rare, des lors qu'll est saisi dans un système d'exclusions ot de relations, sijalfie tout autant qu'in terme frequent ... A partir de comblen de trajédies aurala-je le drolt de "genérellser" uno situction raintenze? Clng, 81x, dix? 1 
Comedy in the Fruach Ronissanoe is in one way a 8elf-canscious genres. In that the elements of Its speeches show a ounstant, and unuourl, amarenoss of the aldionco. Frologues and ep1losueg lead the audienoe into and out of the play. Mroughout the action, agldes and monologues remind them that they are at the play. We find this gelf-consolousness loss often in trasedys in in ilsh Ronalseance comedys in Nollexe; or in modern comedy. Yot in another may, the French Renaissince genre stands gatde from the adience, fring them comparatively fon of the toploal referenoes that oun be most offective in cumedy. Comparetively $\mathrm{fer}$, that 18, comparos with the farces and related jonres, for instanoe the Exane archer de Bawnolet, which autirises the corps oreated by Chaxies VII in 1448. The comlo rorld 18 a eeparate one. ${ }^{1}$ In a more general way, wo mey ask whether tho conociles are partloularly relevint to thelr timas, as auny of the tragedies were claimed to be (Garnter sald thet hts pozole vas "propre pour y volr despeinctes

1 A change may have oocurred about the inid-century. in 4 Deoember 1550 91r John Karone reported from Blole that proclamations had been 1ssuod to restrain freadom of speech touching the reench king and the Council, and rished that there were a similar restriotion in andand. "Whay were wont in thelr faroes to spare no man; but now they are bridled for that polnt" (Crlondar of State Papera, Forel nn Serles, 1547-1553, p. 63; quoted frors Franoes Yates, Contribution to the study of the French sooial arema in the sixteenth contury, unpublished thesis for the decree of ...., Londan, 1926, p. 7.) 
255

les calamite de ce camp" ): probably they are only inoidantully Bo, os when Belleau refers to the sieges of Le Havre or Poitiers. Social critioler is rare, found in only a fer character o, and situations 1 ike Jodelle's hedonist churchman or Belles's aissatisfied men of law. The prineles? a lm of Punch Ranaisseuce comedy was not moral teaching of any kind, but delight. 
Appendix A \& expopses of the plave.

\section{Jodeller L'Eusène.}

I. Dujène (an abbê) and llessire Jean (hls ohaplain) discuss the luxury of a churchman's ilfe. Bugene has marriod Alix off to Gufllaume, le bon lourdent, but is now worried. lest Guillaume should realise whys nomely, that fugine misht the more easily enjoy her favours. - Hewsire Jean, alon, reveals himself as Eugeno's parraite, and oonfirms that hujène is groning careless. - Gulliaume and Alix display their respeotive simplicity and easy morels.

II. Florimond has retumad to Paris from the wares he is an old flane of Alix, and is anxious to renew the reiotionsh1p. He and his follower isnault disouss Paris, the wars, anc learning, before srnsult goes off to find ilix. - Helène, Sutèna's siater, elone: she had herself been fond of Florinond, but he had been alsoourazed by her laok of apparent respongs. She tells lusene of Plorimond's amival, he 18, rightly, apprahensive.

III. Amsult returns oith the news that $A I 1 \times$ is marriod, and why. Mlorimond is furlous ho has some fumiture Is $\$ 11 x^{\prime}$ house, and deoldes ho w1ll at least flrst roclain this.

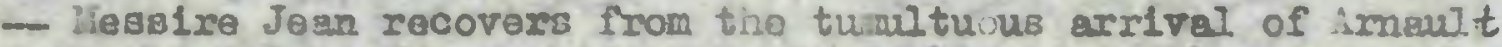
In AllX' house, whioh ho reports to Augene and Hélèno. No solution ocours. - Morimond beats Alix, and with Amalt oversees the removal of h1s furniture.

IV. Culllaume, suzaled by the whole thing, goes to see Bujene. 1'atthiou, Gulllaume's oreditor, arrives and domands

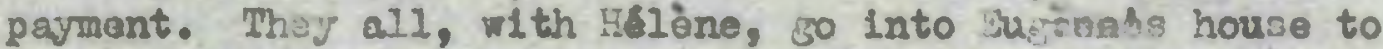
discuss the mattor. - Florimoni dooldes to kill bugene. Du, ìne realises the danger and all the problems and retires alone to think.

V. Sugène has thought of the solutions. Hellene shall be reounolled with Horimond, and hintthieu is to be offered a benefloe for one of his sons. Both of these sre parrled out,

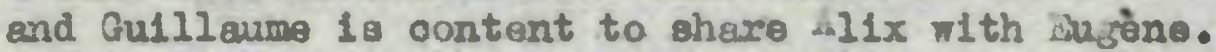




\section{Grớln: Ia tresorì̀re.}

I. Loys (a gentleman) discusses with Richard (his relet) the progresa of his love for Constante, wife of the Tresorier, a Government official. The Irosorier's inpendin ebsonoe may result in some suocess. Richard marvols at his mister's folly in loving so inconstant a woman. - Fiohard on his master's behalf offers the Tresorier intere日t to obtain perment of a sum owed. - Harle, Constante's chsmbernald, is overheard by Rlchard as she reflects that Loys takes second plase to the Protenotaire in her mistress' affections.

II. The Protenotaire ( $p$ robably a legal official ${ }^{1}$ ) discussos with 3ontface (his valet) the projress of his love for constante. The rrotenotalre is ahort of iloney; Bonifsce promises to use his injenuity to ootaln some. - Bonlface overhears Constante promlsing Rlohard a rendezrous for Loys 3 and then succeeds in borrowing 150 escus from Constante herself. - 2he iresorler tries to borrow money from Sulpice. - Mrle promises herself the pleanure of retuming Bonifrce's adranoes.

III. Loys reflects on the profit motive for hinan actions, and on Constinte. Hichard informshim that the Tresorler will produce the moneys then attempts, unsuccesefully, to seduce Irarie. Constante 3001 de her for chattering to Richard, then herself ronlocts, strangely, on the inconstancy of man. - The Protenotalre appears, anci Constante lets hil into the house - but jicherd sees this and rows that his mater shail have vengeanoc.

IV. RIchard has told Loys that he has seen. Loys reflacts bitterly, and interrogates licnard to be sure. - The Tresorier and Sulpice arrive, they and loys and Richard and an extre supgorter Thomas all try to enter the house and in the end breal: the door dom. - liarle energes and reports that the Protenotalre was caucht in flecrente delictos then Bonlface, who hild esoaped by flight, joins her.

V. Sulpioe and the Tresorier attempt to calm Loys and to prevent him from makin; the affair public; Loys ayroes on conlition that he receives the money hack that he has given to constante, and that the two quarterg' money paid hlm by the Iresorier shall be null and vold. - The Protenotalre and Bonfface deolde to keep the money lent them by Constante. - Merie 218018 content, and plans more aroura.

\footnotetext{
1 Cr. Grérin, Thbêtre complot, ed. L. PInvert, Tarls, 1922, p. 354 .
} 


\section{Grévins Los Ëbahle.}

I. Joser aloner his wife Agnes left him three years ago for a lover, taking his money, and it seems that she has died. He is now engaged to Madelon, Gerard's daughter. Liarion, lavandlère, determines to prevent him, for although ho olaimo to be vigorous enough for love, he wears a fur cost, has catarrh, oold and a cough. Antolne, his servant, allies himself aith larion.

II. L'Adrooat, in love with Kadelon, laments her en ${ }^{2}$ zement to Josse. He rejeots h1s oousin the Gentilhomme's acivice to turn to other women. With Julien his servant and the Gentilhome, he plans to try to seoure bladelon for himself. Panthalecne, yot another sultor, makes a brlef appearance serenadin her. Wartion plans to borrow Josse's olothes from Antolne for L'ddrocat 80 that he may easily onter Cerard's houre. Hadelon lamants.

\section{Claude, maquerelles the trade is not what it} was. She has Asmes in hor house, and promises her to the Gent12homme. I'idrocst, disguised as Josse, goes into forard's house; but Imediately Goracd appears.

IV. L'Adrocat emerges, full of for at his success, and avolds cerard (who had seen him through the keyhole whout penetrating the disgulse). Josse prepares to 80 to serdelon; Antoine returns with the olothes only just in time. He sets out, cerard taxes him with his amorous explolts, whioh he Indignantly denles, from whloh Gerard ooncludes that he now Iishes to repudlate Hadelon. Hadelon foars for the future, and harlon consoles her. L'Adrooat tells hls cousin of his sucoess . Jullen g0os off to find almllar game.

\section{Panthaleone is serenading ajain, unt1l Jullen}

Interrupts. Josse arrivas to f1 jht Gerard, but Jullen puts all the bleme for the seduction on Panthuleane. Aomès axrivos with the dentilhomay Josse reoojnises her, while panthaleone also has a olain on her, havin; kept her in Lyon for three jears. Josse is forced to take her brok, Panthaleone is chased off, while a. mairlase between L'idvocnt and Ladelon will be arringou. 


\section{Belleaus Lo Roconme.}

I. Janne the mald, then Maistre Jehan the olerk, complain of their hard work and of the housohold. Madamo appears; her soumess fustifies some at least of their complaints. We lourn that Monsieur, her husband, is courtins Antoinotte, a ward in their house, who, however, has an affeotion for a captain. Antoinotte lemonts. Malatre Jehen, who had fone to the paleis de iustice, rotums and invel ghs asainist it.

II. L'Anoureux, an ailvooste like lifonsieur, deliverg a monologue an the torments of love. Potiron, his valet, axrives; we loum that Honsiour for his om and is planning to marry Antoinette off to Malatre Johan. Potiron and Jann tell Malstre Johan of this.

III. Monsieur praises the virtues of Love and laments his own wife's sourness. He tries to appease her tells her that the oaptain 18 dead and atternts to persuade her of the virtues of his plan - whioh L'Anoureux, Potiron and Janne plan to thwart.

IV. Antoinetto lements the oaptain's death and tries to reoonclle herse If to the 1dea of lialetro Jehan as a husband. Janne is ordered to huy food for the engagement dinner that evening. Widame and hor nol ghbour discuss the proposed marrisge. ...nsleur hopes all will sal off without wishap. I' hinoureux on loves Potiron tells him that the oaptain is dead.

V. The coptain axrives with hio valet Bermand, and they 80 into the house. Janne reports. Then the Gentilhomes de Folotou aiso arrives and goes in. Malstre Johan comes out, then L'Anoureux 3 we learn that the Gentilhomme de Poictou is intolnette's father, that a marrioge has been arranged between Antolnette and I'Amoureux, that lionsleur Ls consequently thwarted, that L'dmoureux has been fiven a post as consilller and the osptain an option or a spare nieoe. 


\section{Le Tallles Les Corrivenx.}

I. Restitue conficies her woes to her nurses not only 1s she pregnent by Flladelfe, but Filadelfe has transferred his affections to lleurdelys. The zurse, takins a prictioul view, suegests that ohe try to 80 to tho country to dispose of the child. - Filrdelfe, waitins for news from Claudo, a servant in Fleurdelys' house, Justifles his Infidelity by the ircesistiblo power of love. Claude arrives; he has arranged for Fllacielfo to enter the house vithin the hour, and he vill ol mal with a torch when the time ocmes. Gillet, Filadelfe'g velet, declares hinself to be more down to earth than "ces amoureux transis". iladelfo giva instructions for the oomins adventure.

II. Luvertre, too, is planning an ontry into sleurdelys' house. Alizon, the other servant, arranges to si nal to him with a distaff when the time oomes. Her mater Fremin, on his way to town on important business, urges her to t ake ogre of Meurdelys. lils own relationshlp with ilizon seems equivocal.

\section{Jaqueline, Restitue's mother, arees to let her} go to the country, as she is unvell, but has meanwhile surenonod a doctor. Clande and Alizon both appear at the same spot at the same moment to sive thelr respective simals; they squable, and Claude lesves. But now there are nolses off in Fleurdelys' house, and the doctor has siven tho same angy in Restitue's. Finter Gillet, then Felippes (Duvertre's father's servant), fro: whom wo leam that the two youn men both entered Fleurdelys' house, that there was $\mathrm{fl}$ ghting, and that the serjeants of the watch arrived and carrled thom and claudo off to prison.

IV. Benard, Flladelfo's father, arrives from Hetz with his glutton valet Felix. Jaqueline heaps reprosches on hin for h1s son's behaviour, and his son's attempt on leurdeljs' honour is also revealed. Fremin and 3onard neet; we leam that Fleurdolys is in fact Sonard's daushter, lost at the slege of Yotz ten years aro and taken in by Fremin.

V. Inter Gerard, Juvertre's father with the two other men (Fromin and Benard) a solution is worked outs Euvertre shall marry Flourdelys, and Elladelfe Restitue. They so off with Fhil andre, the mester of the watch. The three valets, by now drunk, provide some 11, ht rellef. After some frightening of the youne men with the prcapeot of the law, the solutions are asreed and, moreover, Benard in1 il marry Jaqueline. 


\section{Lariveys Loo Isprits.}

I. SaverIn'B brother H1lalro, since he and BIIz beth hIs wfo ara childlass, have brousht up Ecrtuné, one of Severin's sons. Sacuuse of Severin's miserliness, his daushter Laurence oannot find a matoh, nor hug Urbain h1s other son the allowanoe a young man should have. - iortuné bnd his servant irontins Gortuns is in love ith Apoline, a eirl who is in a convent, theugh she hes not made her profossion. - Ruffln, maquareru, promises Urbain hls ellolane, on paymont of ten sous. - Frontin can bive Fortuné no good news of his Apolin. Leanwhlle Ruffin has brokitut Pellolane.

II. Dasire is in love with Laurence; Neontlu oan offer him no good news elther. Severin arrivas prontin, to pravent his goins in and discovering Urbain and Follolane, persuzdes him that the house is full of shosts. Severin joes off, flrgt hicing hls zurse (with 2,000 écus in 1t) as he does not wish to caIry it around. DesiIs, who wos hidden, sees hlm and takes the bcus, putting pobbles in their place. Severin retums with Frontin, who pronlses to find a soroorer to exoroloe the frosts; Severin cheois that the ourse is st1ll in its hidin plsoo.

III. N. Josse the sorcerer, bribed by Frontin, confures the hostsi erontin pretending to be one of then takes the rinc from the blindfolded Severin's finger 28 a sign that they have left the house. Fellolane and Urbain go into kilalre's house whloh 13 close by. Severin sonds if. Josse aways Ruffln almost fires the plot away to Severin, but 18 prevented by siontin. Soverin discovere the theft of the coina.

IV. H1latre tries to d18suede Fortune from hlo affalr with Apoline. Fortung telle H1laire of Fellclane's honourable parentase and sends Pasquette, servante, to get new 3 of hpoline. Cerard, Follclane's father, arrivas in town. Paquette sives away to Hilalre the faot that Apolino has had a child.

V. Gerand has heard the neva of Fellolane, but fuffin assures him that a marriage with Urbain my be posalble. They go to see severin, who is interested In nothlog but his purse; and then look for sellolene at Hilalre's house. - Hilalre has been to the convent and arranged a marriage betweon Jortuné and Apoline. Meanmile, also by Z1la1re's intervention, the marrisos between Urbain and Moliolane and Desiré and Laurence nool only Severin'a consent. The purso 18 produoed, finanolal axrangrments mide that gatisfy Severin, and the marriages settled. 
I. Loulss and her daunter Genevieve, are on their way to churoh, very early in order to avolic Baslle and Rodomont, who in Loulse's eyes axe both urielcome sultors for ceneviève. Hivelet, Ilodomont's leckey, sees thes $50 \mathrm{by}$, then Rodomont arrives. Thoy ovorhear 3asile, with his sorvant intoine, planninj to anter Ceneviève's house disguised as sustache. Baslle persuades Frangolse, Pleilla farme, to try to win cenevieve orer to the Idea and fix a definite time - whioh she does. Nivolet plane to ses that his master selzes thls chanoe to enter the house disguleed as ustache beforo Basile does.

II. Girard wishes to axrange the engagement of his son justache to feneviève, but sustcohe le reluctant bec use he knowe that she fivours Basile. Frangolse succeods in putting him off still further. Rodomont borrows a scrrlet costume from him, Identicel to the one which Basile has alrealy borrowed from him. Thangelse tells Basile what she hes done.

III. Rodomont, dibulsed, is gelzed by throe sergents for Cobt to Thomiss, a mischant, before he has a chance to enter Genovieve's house. Basile, alou discuised, sees him hauled off. Semaisson,

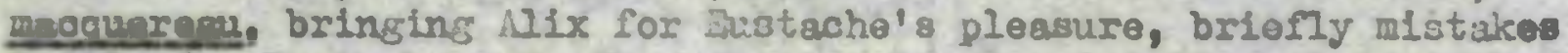
3asile for Eustacho. Besile goes in, learing Antolne outside, who too late sees Loulse retumin l.oms early. She goes in, looks through the keytrole, takes Baslle for sustrche, locks them in, and soes off to look for Gerard). Leanihlle, intoine, with Perrette, fonoviève'g mald, sets Basile out of the locked room through a mindow.

IV. Basile fotohes Alix and puts her in his plsce in the borrowed costume to decelve Loulaes on the wey they pass Thomes (who is In fact $\mathrm{Mlix}$ husband. Rodomont has been freed. Ee is still dressed as llustsohe (and is briefly taken for him by Goraxd) but decides it is too late to try to enter Generiève's house. Loulse taxes Gerard with h1s 80n's supposed attaok on Generiève's honour but Eustaohe explains to him that it was Basle. Evantuelly Loulso unlocks the door, but finds only AllX mith her daughter.

7. Frangolse reports to Besile that Loulse's latest 1dea 18 to marry ber dauchter to iodomont. Genevieve at her window, and Basle below, exchange declarations of love. Rodomont, hearine that Basile has had Genevièvo's virinity, consequently refuses her hand when it is offered to hin. Loulae realises the truth, gives in and consents to the marriage of Bas1le and Geneviève. 
I. Auguatin 18 in love with the wldow Angtique. He talks to Beta, hor servant, who he hopes will help hin to her favours. - Dom Dlejos, a Spanieh brasgart in exile from liaples, is in love with her too; in which Gaster, a parasite, encourages him. Gaster, alone, on his profossion of parasite.

II. Gaster, too, attermts to einploy Beta, for his mastor; sho pluys for t1me, fiving him a promise for tomorrow. Augustin overheare, but sho placater hin with the pronise of an lmaodiste rendezvous. - Ambrolse, husustin's father, dlsapproves of the affair with the widow though he fails to get definite onfirmation of It out of Loys, his son's servant, he nevertheless decides to out his s0n's allowanoe to the bare sinimum. - Auzustin 18 overjoyed at success with Anjliche. To oounter his father's decision, Loys suggests he turn to his friend Camille for money, and also for help if neoessary egeinst Dieghos.

III. Cantlle esrees, unc they plan to 50 to Anstique's after lunoh. Dieghos, rejected, goes off with Gaster to lunch. In the aftermoon, Augustin and Camille arrive at Ansellque's first; but Angellque is forced to invent a story for betting them out of the house when Dleghos and Gaster arrive too. Tho also succoed in puttin of Dlegtios and Gerster unt1 the noxt day. Virginie, her aupposed daughtex, laments: her fither lost all his possessions through participatins in the robellion at llaples, and has aled in Paris leavins hor alone rith Anjelique, who is not in fuct her Dolher. Jeaninile, Camille has fallen in love with Virginie, and plans hor he may win her.

IV. Comeille, Virginie's servant, laments to husustin and Angoliques Camille has sucoseded in making his was into the house and seducing Vircinis. hu ustin suggests they try to porsusde hlm to marry her, and goes off to flnd him. Heanmile Loys has found his orn pleasures.

V. Harc-Aurel, a jeweller from laples, adnires Puris. Yeoting Camille, he la able to tell him what Virginie's family ia, and moreover that by culnoldence Camille has becone heir to the lost fortunes of that family. Canille decldes he w1ll reany her, and with Augretin goes off to see her. Ioys follows with lisic-surel. Dloghos 18 furlous - unt1l Louppes, s inossengor, tells hil that he is freo to return to daples, where a marriege has been arringed for hln. Gaster dooldes ho must look for a new reohe à lalts a marrlage will be arranged between VIrginle and Canllie, and Beta and Gaster go off to tho engagement banquet. 


\section{Perxin: Les esooliers.}

I. Misclou has heard that his son Sobrin Instead of studying 1s spendin; time and woney on a love-affalr, and tries unsuccessfully to obtain the truth from his son's valet Finot. - Grassette, talkine to her sexvant Babllle, reveals that she is not interested in Sobrin, but in the $108 \mathrm{~s}$ weslthy Corbon. - iriquet, a neighbour, reveals to tarin that his daughter Grasset te is entertaining lovers.

II. Sobrin, againat Friquet's advioe, deolares that he will puroue hls love fer Grassette. Fnet, on his behalf, begins to ${ }^{\prime}$ in Bab1lle over. - Corbon declares thet he prefers learntraz, which can ralse hls social status, to sacrous pureults. - Haolou warns his son that he will not support him if he does not concentrate on his studies.

III. Bablile sjesks for jobrin to Grassette, but without suecess; this sho reports to Finet. Finet reports it to jobrin, who 18 still deterained Finot promises to think sein. - Harin suspects Babille of alding her mistress' amoure. - Finet meets Corbon and bejins to plan in that direction.

IV. It is agroed between Nobxin, Corbon and Finet that a rendereous ahal!. be arranged between Corbon and Grassetto, but that it shall ube Sobrin, disgulsed and at night, tho shall keep 1t. In roturn, Corban is to havc the benefloe that Sobrin controls. - Finet arranges the rendezvous with 3abllle. - Sobrin, disfuised as a pousant and speaking in dialeot, is admitted by liarin to the coliar. - Corbon expresses his plessure. Sobrin einerges and reoounts hls success to Finet. - Frlquet and karin havn alscovered that heo happenod, and haclou too learns it from Jarin.

V. Sobrin and Finet jain priquet to their side by threats and promises, and he persuades both diarin and Haclou to favour the marriage of Sobrin and Grassette. He reports this to sobrin and the marriage 18 arranged. 
Godards Les jeoguisez.

I. Gregoire laments: his wife has died, his household expenses are rising, while rouventerd is demanding a sum of money that Grejolre holds in trust for him. - Olivier alone, then with Maudolé, his servants he 13 in love with Louvse, Grezolre's ulaghter.

II. Prouventard boasts to his Isckey Vaduple of his allitary explo1ts, and that he will scan recover the money. cregoire decides to offer him Louyse's hand instead of the woney; ho tells Lourge, then makes the offer - but Prouventard Indi nantly refuses 1t. - Luade disoovers thst Grojolro needs a now valet, and sujgests that olivier take the job.

III. OIfier and Maudole exohange clothes. Olivior offere his services to Grejolre and 1s accepted. Maudole brags in olivier's olothes; rouventari at flrot is terrifled, but discovering ha 13 merely a valet, with Vadupié's sid chases him off. - dicnle, Louysa's servant, sdrises her that Prouventard would be a poor setoh; meanwhlle Olivior in making a good linpression. "iaudole in vain demands his clothes back. Olivier on Love. Te declares himsolf to Loupse, who however xegisters only alam.

IV. On Nioole's an: setion, Louyse now encourages Olivier. - Grezolre sends Olivier to : rouventard, but Cllviez auzsests as a botter matoh than Prouvantard a rich young man whom ho knows. Ilaudolb, inpersonating Olivier, is to be that rloh young man, a solsein which Lou se approves. Haudolf oamies out his part, but makes the slip of promising to fotoh his futher, Plerre Galland, who does not in faot live in the town. Clivier and Toudole, by blacknallin, Passotrouvant, a passer-by, with attempted rojbery, persusde him to impersonate Pierre Galland; this he sucoessivuliy does.

7. Pierre Galland himself appears unexpeotedly in tow, and by colncldenoe meets Gregolr. Fassetrouvent sill maintains himeif to bo Plerre Galland, and tempers rlse. Núadolés appears, st11l impersonating 0livier. The oonsusion increases, then is gradually cleared as lieudole reveals the truth. The merriege of Clivier and Louyse is evontually asreed, Prouventart is given an option on a spare sister of Olivier, and an engrgeivent dinner is prepared. 


\section{Anon (Hardy?): Los ramonoure.}

I. Lo Cepitaine Soanderbec boasts to his valet Gelafres and Instructs his sister Dians to stay quietly at home and see no ono. - Phillppes discusses with his ralet Martin his love for Diane, then taiks to the pedant Bonargius; liartin wino to their s1de the frult-seller Dano Bonne, who beglns to vin Diene vver. The Captain returns. Ph1llppes serenados Dlane, but the Captain apperars, and Phllippes is foroed to leave.

II. Madel on (courtisene) disousses with Dame Elande (macquerelle) the possiblilty of marrying the Captain. Bejotiations are begun. - vilippes and liartin acain turn to. Dame Borno, who takes a letter to Dlanes but the Captain aseln intermpts, oven though phllippes succeods in chesing him into the house. Hiane gitus liartin a note for his master.

III. The Captain gives orders that the houge is to be oiesneds Dlane ls to engage some ohimney-sweeps. These are Fhillppes and Llartin, who send Gelafire to fetoh inore Jine and cerry off Dlano disgrised as a sweep to claude's house. The Captain returns to find her zone. Bonarsius, hldden, has seen them.

IV. Kalatre N1colos, Kadelon's father, has arrived in Paris. - Bonarsius bribes Clisude to simuscle him into Diane's room that nizht; but s.rtin overhears the arrangement. - The Captain is determined to recover Diane. liadelon is in the bands of justice for dabt, she joes off aith the Captain and the Beriente. - lartin, unlenoim to Claude, has set a prost1tute in DLane's plade, and claude a a sroed lots in Bonarsius. Martin's and PhIllppos'student frlends, disulsed as the watch, surprise hin there, but for the promise of twelve sacus let him 80 .

V. The Captain and Itadelon are freo and searohing for Dlane and Philippes. - The Captain's rich uncle Dubiuleson has mot Madelon'g father Halstre Iloolas. - Claude glvos Galoffre tho word to follow kiartin, thus setting the captain on Dlane's track. Dubuisson and $M$. N1colas find lifdelon, who has by now aarried the Cuptain. - The Captain has found Phillppes and Dlane; eventually both the marriages are approved. 


\section{Come111e: Uélite.}

I. Braste declares to hls friend Firsis hls love for iskl1te. Tirals is sceptical about marrlage, deolarino that if he marries, it will be for Ilnanclal adrantage. Fragte, to chanje his Iriand's opinion, Introduces him to 11811 te - and sucoesds only tou well. - Iirsis finds his sister Clorls with her lover Philandre, and hints at his new lore.

II. Fraste rejrets that he ever introduoed Tirsis to lélite, the more so since 4811 to harself now shows 81 gne of her crowing arfeot1on and vows to take aotion. - Tirels rgads to his olster a sonnet in pralse of lislite wioh he has written, osto:sibly for Irats. Cloris sees the truth and encourages him. - Eraste has rritten a false love letter, ostonsibly from kelite to Mhilandre, who hovipver renues to leave his Clorls, desplte iraste's encouragonent. - élite indicates to pirsis that ohe retums his love, and Irsis ives har the sonnet.

III. The $\nabla a$ in Philandre, Flettered at K811te's supposed affection for hin, prepares to rotum 1t. He shows T1rsis two further

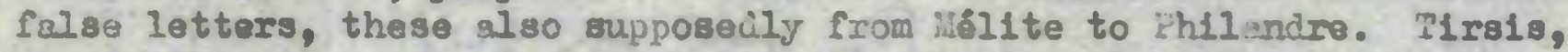
alone, lamants, Ho shows tho lettors to Claris, who trias to console him by pointing out helite's inoonetant charsoter; und herself deternines to leave the inconstent Philandre. She showg Philandre that she has the letters, and says that she intends to shor them to islite as a proof of Philandre's iudiscretion.

IV. $1911 t^{\prime} 3$ nurse triog to pexeuade her to encourano the rivh Traste rather than Tirsis. - Clorfa showe Mẻlte the lettero, but she denounoes then as forgorles. Liels (a friend of T1rais) annominoe IIrs18' death, at whlch Ifél1te imodiately fainto. - Eraste, rejoicing at MI81s' death, hears that 811 te 18 dead 3180 , and falls Into a fit of madrees, Imagining that ho too 18 dead. - Phil indre, in search of his rival Plrsis, hoars of hls and inellts's death, and of the falsity of the letters, from the mad reste. - Lisis reveals that his announoement was false, dosignod to tost dél1te's affeotions.

V. Mfite' nurse brlage iroste beok to santty. - Philandre tries, and falle, to obtaln Clorls' pardon. TIre1s and liélite, now to ehhor, consider her excessivaly hart. Iraste canfesses and is pardoned; and an attachment betweon him and Cloris is bejun. The nurbe speaks a clcsing inonolosue. 
Appendix 38 Grofin's te Maubartine.

La Joubertine is possibly a third ooredy by Grêvin. Pinvert supposed it to be 1dentioal with le tresorlère (GÍvin, Thátre oomplet, Par19, 1922, pp. 353-4; Jacques Grévin, Paris, 1899, pp. 172-3);

7. Lebigue considers that it is probably rathor a separate olay (Tableax ... p. 305). The evidence is as follows.

Gróvin tells us that he wrote a comedy called La rimbertina,

reforring (in the preface Au leoteur to Les esbahls and La tresortère) tos

coux gui ont veu la Naubartine presniére Conédie que je mls en jeu, et que j'aroye bien délibóré te donner, 81 elle ne n'eust est6 desrobée.

It is certainiy possible that this was in fact an earlier version of La tresoridre, especially as the aotion of La tresortère takes place "non loing de la place laubert" (La tresortère, prolozue).

It is true, also, that Le trosorilore wes first written for a performance in January 1559 and not performed until February 1559 , Bo that a remenlement in between is quite sonceivable: a healing to the play reads:

Ceste comadie fut falcte par lo ocimandemant fu rol Henry II pour servir aux nopces de madame Claude, duchese de Lorruino, mals pour quelçues empeschemens différés et depuls mlse on jeu è Parlo au collège de Bogurvils ... lo $v$ do fevrier MDLVIII.

It seems, too, that a compliant, yerhaps the csuse of such a 
renantement, had been lodged by soms ladies of the ifaubert quanters ï oeste plaincte, qu1 ful falote
Pour la rancoune ot lo soucy
Dos dawes de ce quartier oy.

(Les e日bahis, prologue)

These are the argumanta in ferour of ldentifyine La llaubertine with La tresorlàre. 3ut thoy sro none of them oonclusives for instance, the kavoert quastor was a student quarter, so that two plays coild quite naturally bo set there. And they aro outwol ghod by one argument, that the one roferince to La Haubertine occurs in the profaoe to both La tresorière and Les asbahis, exaotly 0.3 though it were in fact a third play. Grévin speciflcally says there that he is not ptblishing La Haubertina: "que j'avoye blen dóliberé tio donner, 81 elle ne m'oust esté desrobée." If La tresortère and La hiubertios were 1dentical, or even difierent vereions of the same play, this would not make good Bense. It is more likely, therefore, that Ta lirubertine was a third conedy by crevin. 


\section{BIBLIOGRAPHY}

1. Siapuecripte.

Anon [poselbly Alexsncire Hardy], Les ramonnoure. Blbllothòque de 1'Arsenal, Fonds Rondel, MS 194. El ghteenth century hand. In addition, a nineteonth century oopy from this manusoript is in the library of the Soolst' des Autours Dremat1ques. Cf. Les ramomeure, ad. A. G111, Par18, 1957, 9p. xi11-25111.

Barf, Jean-Antoine de, L'eunuque. Blbliothèque Nationale, WS F. Fr. 867. The manuscript oontains only L'eunuque, in a sixteenth contury hand, possibly Barf's om. 52 If. Vellum-bound. Headed "L'Eunuque de Teranoe par Bayf". A note at the and adde "Achovbe Lendemain do Noel derant Jour 1565".

3runo, Glordano, Il Candolaio. Bibllothèque Rationsle, US F. Fr. n.e. 2879, ff. 226-2487. A translation Into French of Bruno's Il Candelelo, whioh was originally publiahod in Parls in 1582 (cf. section 2 balow), bound in with other manusoript coples of plays of varying dates. Probably early seventeenth oentury hand. Headed aimply "Candolalo". Not the same translation as that publishod as 3onifaoe et le pédent in 1633 (of. seotion 2 below).

Grérin, Jacques, c. 300 alterations in Orivin's hand in a copy of he thestre de Jcrques Grevin, Paris, 1561, In the thuebe Plantin-bioretus, Anvers. Alterations probably made for a profected now edition, to be printed by Plantin, whloh nerer appoared. Alterations possibly dating from Dotober 1567 when Grévin was in Anvers. Cf. L. Pinvert, Jeaques Grérin, Paris, 1899, p. 64. PInvert reproduces the first pege of La tresortire from this oopy, 1b1d., p. 65.

Larlvey, Pierre do. The 3ritich Ifuseun oopy of Les six premieres oomadies, Par1s, 1579, has a manuscript 11st of sotors written on the 11st of Dramatis permonae of Le morfondu. Late olxteenth century or more probably early serenteenth century hand. Cf. chapter II, $\checkmark$ abore. 
Perrin, Frangols, Les escoliers. Blbliothèqu Nationale, MS F. Fr. 9299, ff. 220-262\%. One of a number of coples of plays In a nineteenth century hand according to the catalogue of the Blbliotheque Nationale, made by H. de Soleinne. Copled from the printed version in Slohom Invisseur, Parls, Gulllaume Chaudis̀re, 1589 (of. section 2 belon).

2. Books printed before 1636 (except secondary sources).

Location of the copy haed is given; a complete list of known coples is not attempted.

Ambolso, Frangols d', Les Neapolítainos, comedie franoolse fort faosoleuse. Sur le eufet d'une Histolre d'un Parlsion. un Espagpele et un Itallon. Par1s, Abel l'Anuelier, 1504. Privilogo 2 December, 1583 (B1bliotheque de 1'Arsenal). - The Blbliothòque de l'Arsenel possesses two copless 1) Fonde Rondel, Rf. 1239, t1tle as above, privilege ands "Donné à Paris le 2. Decemibe, 1583. Pa: le Conse11". 2) Anoien Fonds, $8^{\circ}$ B.I. 14.478, t1tle cont ts the word "fort", which has necessitated re-setting the word "froecleuse", priv1lego onde "Danné à Paris 10 2. Decombre, 1583. algné Par lo Canse11 DE NGUF-VILLI". No other apparent alterations. These are probably amall alterations introluoed by L'hngeller in the coures of printine, rather than indiations of a second impreselon. Ho coples other than these two are known.

Andrein1 da P1stola, Francesco, Le bravure del cepltano Spaventio, Dirise in moltt restonament In forma di D1alogo. D1

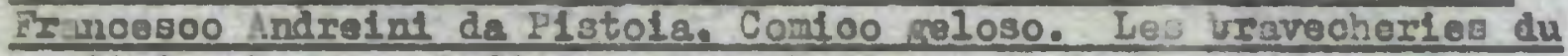
oapitaine Sparente. divisees en plusieurs discours en foxpe de

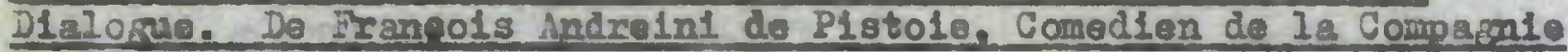
des Jaloux. Tradulotes nar T. .F.P. Jsoquos de Fontery Pariglen]. Paris, David le Clere, 1608 . Piviloge 31 Karch 1608 3ijliothaque de l'Arsenal). - A traislation of the first $81 x$ of 55 dialogues published by Andreinl in 1607: Le bravure del casitano Spavento, divise in molti racionenenti In Forme il Dieloro, di Franoesco And inini da Platola Comion Geloso. Vanioo, Glaoomo Antonío Somasoo, I6C? (31bllothique de I'Areenal).

Balf, Jean-Antolno de, Le brave, oomedie de Jan Antolne de Baif, 
Par18, Robert Eistienne, 1567. No privilege (B1bliothèque de 1'Arrenal). Aoted, woording to the t1tle-pase, on Tuesday 28 Jamrary 1567 in the Hotel de Gurse in the presence of the King.

BaIf, Jean-Antoine de, Le brave, comedle de Jan Antolne de Baif, Par18, Robort Sistlenne, 1567. No priv1lege (B1bliothèque de I'Arsenal). Aoted, acoording to the title-page, on Tuesdey 28 January, 1567 in the Hottel do culse in the presenoe of the IIng. Includes "les ohants reoltez entre les actes de la cojedie", by Ronsard, Balf, Despartes, Fllloul and Belleam; as there are flve of them and fire acts in the play, they may elther have preceded or followed each act. They are in pralse of the Royal Fandly and here no comreetion with the content of the play.

Des jowx, Paris, Luoas Breyer, 1572 (Biblluthèque de I'Arsenal) La muscript note in the Arsenal copy has changed WDLXII to LDLXIII]. Inoludes Le brave, ff. 89-160, and L'eunuque, 11. 161-208. The "chants" Included in the 1567 edition of Le brave are not jiven hore.

Belleau, Rouy, Les curres poetiquee de leng Bellecu, Paris, Q11les Gilles - or lamert Patisson], 1578 (British juseum - a C1lles Gilles copy). Contains, rol. 2, ff. 110-153, La reconmes eomedle. Pax logr Bellean.

- Le cenrres poet1cues de Bery Belleau, Yar1s, Hamert Patisson [or 0111es G11108], 1585 (B1bliotheque de l'Arsenal - a Whamert Patisson copy). Contains, vol. 2, ff. Illv - 154, ha roconnue, camadle. Par Besy Belleou.

- Les courres poetiques de Remy Bellear, Lyon, Thomas Soubron, 159? (5.1tish iluseur). Contalns, vol. 2, ff. 11lv - 154, La reconnue, conedie. Par Reny Belloau.

-i Les curres poetiques de Remy 3ellegu, Rouen, Claude le villain Lor Jean Berthelin or Thomas Daré], 1604 (British inuevu, a Le Villain copy. Bibliothèque de l'Arsenal, Berthelin and a Daré). Contains, ff. 393-434r, La reconnue, conedie. Par Remy Belleau. 
- La roconnue. A copy of La reconnue, bound separately and follated 111v-154, presumably a part of the 1585 or 1592 odition, 18 in the 31bliothèque de I'Areenal. - Another copy, bound and follated separately, Rouen, Thomas Dare, 1604, a part of the full 1604 odition, is also in the Bibllotheque de 1'Arsenal. - La Vallière, Blbllothèque..., p. 218, Cloranescu, Bibl10 raphie..., p. 111, und Lebegro, 1ableau, p. 285, give a IJTा बतItrox o! La reconme, whlch I have not traced.

Bruno, Glordano, Candelalo comedia del Bruno Nolano Achadentoo d1 nulla Achadomisl dotto 11 fastidito. In Triatitia

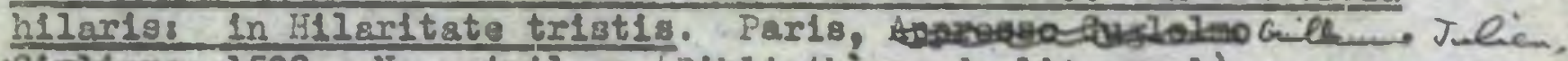
1582. No privilege (31bliothèque de l'Areonal).

- Bonlface et la pedant oomedie on prose, Imltee de l'Itallen de Bruno Xolano. Paris, Plerre Wenard, 1533. Privilege 2 April 1633 (B1bIlotheque de l'Arsenal). Based on II Candelalo. Aocording to the "Au lecteur", cuts and ohsmiges have been mudes in faot, rather cuts than ohanges, this version has lost much of the 11 fe of the orfiglnal. Not the same as a translation of Il Candelato in Bibllothèque Nationale, uS P. Fr. n.8. 2879,88 section I ebove.

Chappus, Cabriel, Les ronules colester, terrestros ot infermaux ... Irez des eurres do Donl Florentin. Dar Gabriol Chappuls Touranseau. Depuls revouz, corrlgez et augmentez du

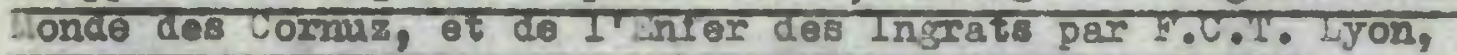

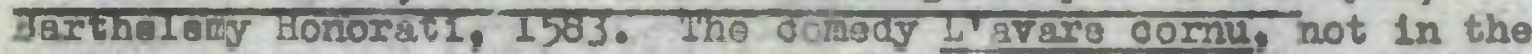
earlier editions of Les mandes oelestes..., ocouples pp. 666-714. Cf. chupter I, 11 above.

Cornollle, Plerre, Lelito, ou 168 feusses lettres. Ploce comique. PaIls, Mrangols Targe, 1633. Privilezo 31 Jamuary 1633 (B1bliotheque Nationale).

Its shelf-maxk is that given by lime Hom--onval for a 1564 adition of La recomnue (Iraductions et adaptations...., II, 24) whtoh 18 otherwlse unknown and appears to be an orror. 
D'Ave8, 800 Troterel.

El1ot, John, Oxtho-epla Gall10s, London, 1593. A set of Fronch-English dialogues. Cf. ohapter I, 11 above.

Estlenno, Charles, Conáde du Bacrifloe, dea profersourr

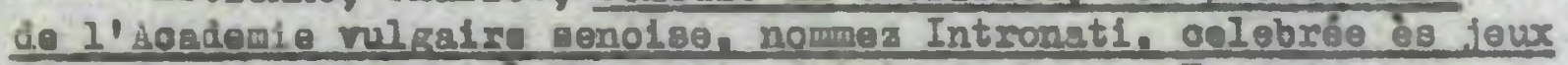

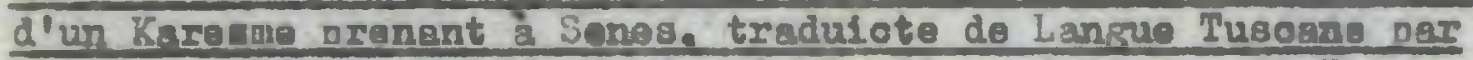
Charles Estlonne. Lyon, Franpois Fradin and Plerre de Tours, 1543 (B1bliotheque do 1'Arsenal).

(Bibliotheque Nationale).

Nat1onale). do., Parlo, Istienno Groulleau, 1556 (31bliothèque

Fonteny, Jaoques de, see Androinl.

Fornaris, Fabrizlo de, Anzolica, oomedia de Fabritio de Fornario Napolítano dotto 11 Can1tano Copcodril10 Comloo Confildente, Paris, Abol I'Angeller, 1585. Ho privilete (Britioh laseum, Bibliotheque de I'Arsenal). The dedication to the Due de Joyeusa refors to perforrance in the Duke's house. CI. ohapter I, il sibove.

- Anzellave Comedle. de Pabrloe de Fournarls Ispolltain, dit le Cenitaine Cooodrille Contare Confidant. Ils 8101 en Francols,

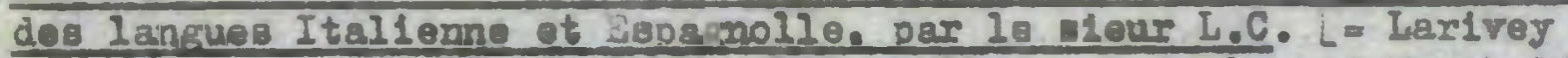
Champeno18?]. Par18, Abel I'Angeller, 1599. Pr1711080 8 March 1599 (Bibllothèque de I'Arsenal, ex-11bris V1ollet-le-Duo).

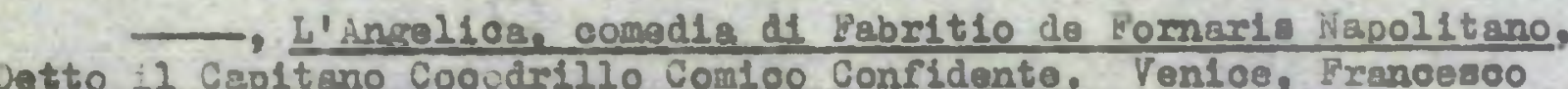
Barllott1, 1607 (3ritioh llueoum). The dedloation refere to "l'Angelloa Comedia del Capitan Cocodrillo, stampate glà In Parige'". 
Godard, Jean, Les ouvses de Jean Godard, Pariolen. Divisees on deux Tomel. A Jienry 1113 , tres-Chrestien et trosvietorlour Roy de Franoe et de Navarre... Iyon, Flerre Landry, 1594. "Ave0 Privilege"/ but none printed (Bibllothàque de 1'Arsenal). Pagination irregular. Vol. II contains Les Desruises, ocmoedie de Jean Godard Parisien. There are five pageo of "Argument our la comoedie do Jean Godard, Par Claudo lo Yrun jurisconsulte Besujoulals", elght pages of a poers "A $\mathrm{Hlcolas}$ de laneues, prealer presilent au Parlenent de Dombes, et au Slege preslatal a Lyon"s and the play pp. 99-208.

- Heslanies poetlques itragiques, comlques, et autres diverues. De l'invention de L.D.L.F. A la Franoe. Lyon, Arbrolses Travers, 1624 (British luseurls Bibliotheque de I'Arsenal, Bibliothèque de Versailles). Containg the "Argument" by Le Brun, the poem to De Langes, and the play pp. 99-208.

Grévin, Jacques, Le theatre de Jaques Grevin de Cler-mont an Beauvaisis, ... Engemble. Ia geoond partie de l'0limpe ot de le Gelodacrye. Paris [Vinoent Sertenos], 1561. Privilegi, accorded to Sertenas, 16 June 1561 (B1bliothàque de l'Arsenal). Contalns, ff. "111 ff. unfollated, 11 sides in 2ll], "Brief disoours pour I'Intelligence de ce theatre; ff. Al - dill an elegy by fionsard to Gróvin; pp. 43-5 "Au lecteur"; pp. 46-111 La triesorlères pp. 112-219 Les esbahts. A copy in the lluse Plantin loretus, Anvers, contains manuscript alterations in Grévin's hands of. section 1 above.

\section{- Le theatre de Jaques Grevin de Cler-mont en} Besuraisia, ... Parin, Vincent Sertenas and Culliawe Barb6, 1562 (3ritish tuseum). Pp. 43-5, "Au lecteur", pp. 46-111 La tresorière pp. 112-219 Les esbahis.

Jodelle, Etlenne, Les Guvres ot Meslanges Poetiques

1 La Vallière, Bibliothècue, pp. 144-5, ol tes Le théêtre de Jeoques Groin, Parls, Robort Etienne, 1560. I have not tracod this edition, nor is it mentionod in 2 invert's edition of Grévin's works, Paris, 1922. 
d'astlenno Jodelle slour du Lymodin. Parls, N1colas Chesnowu and Hanert Patisson, 1574. Privileso 24 September 1574 (Bibllotheque de I'Araenal). L'Sugine, ff. 188t-222t.

-, Les Curres et Kes3 craces poet lques d' istínne Jodelle,

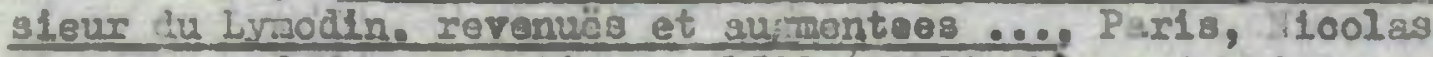
Cheoneau and hamert Patisacn, 1583 (B1bllothogue de I'Axsenal). It turène, 1. 175r-207. 1597. Nat1onale), do., Paris, R. 1e Plzeller, 1583 (B1bl1othèque

Lextrey, Plöre c, Les six premeres comedlee faoecieuses. de Plarre de Lariver. Champeno18. A l'imitation des anolens Groca,

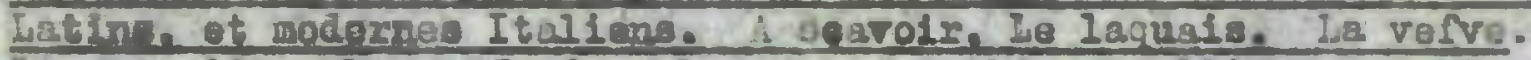
Les esprtits. Le moriondu. Les faloar. Les esoolliers. Paris, Abel I'An oller, 1579. Dedication dated 1 January, 1579. Triv1lege 26 Fobruary, 1579 (3ritish Iluseum, imperfect; Blbliothèque de l'Arwenal).

- Les pomodies feceoleuses de plexse de Lastivey Champeno1s. A l'imitation des anclon Greas, Latins, at modernes

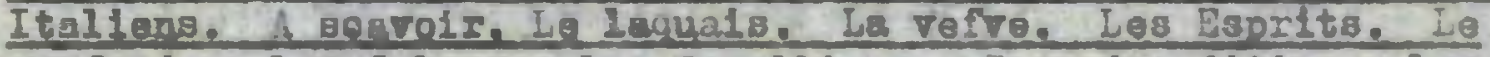
ierfondu. Les Jalowx. Les sooll1ers. Soconde edition. Lyon,

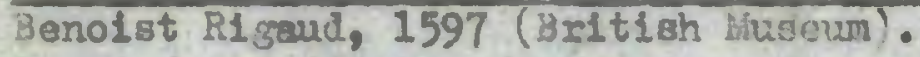

- Les comsdles floecieuses de Plerre de Larivey,

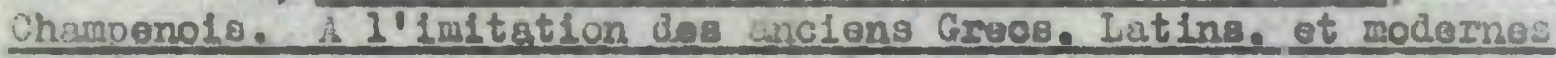
Itgliens. A segvo1r, Le Lanva1s. La verte. Les Jsprits. Le Morfondu, Les Jeloux. Les Bsoolliers. Seoond edition. Rouien, Raphaöl du Pet1t Val, 1600.

de I'Areonal). do., Rouen, Raphä̈l du Potit Val, 1601 (Bibliothòque 
- do. [ ... La Verre... Le Lorfondu ...], Rouen, Rephaël du Pet1l Val, 1611 (Brit1sh Luseum).

- Trols comedies das six dernleres de plerre de Leriver Champonols. A l'lialtation des anciens L810] Grocs, Latins et lodernes Italiens. A Searolr \& La Conśtanoe. Le Fldelle. Et les Tromperies. Troyes, Plerre Chev1llot, 1611. No privilege (3ibliotheque de l'Arsenal). Also exists with a different title-pages Trois nouvelles comedles de Plerre de Lariver. Champenols. A I'Imitation des anoiens Grocs, Latins, et modernes Italiens. A spavoir la Constance, Le Fidello, et Les rromperies. Imprimé à Trojes, st se vendent à Paris. Chez La veufve Jean du Brayet, Jean de Bordeaux, et Claude de Roddes. 1611.

- Les esprits. A copy of Les esprits, bound separately, and follated 111-165v, probably from the 1579 edition, Is in the Blbliotheque de l'srsenal. Conversely, the Brit1sh Museum copy of the 1579 edition lacks Les esprits; it may even be that the Arsenal copy is the missing section. - A copy of Les esprits, bound separately, and pasinated 209-312, from the 1601 edition, is In the British Kuseum.

Lasphrise, lo oapitaine : see Papllion.

La Tallle, Jean de, ha Pemine, ou les Gabeonites... Ensomble plusileurg autres Cuvres poëtiques de Jehan de le Tallle de Bondaror ... et de fou Jaques de la Tajlle son frero ... Parla, Federio kirel, 15731 (Bibllotheque de 1'Arsensl). On the reverse of the titlompage, in the list of contents : "Las Corrivaux, et lo lezromant, Comedies tirees de l'Italien d'Arloste" [in faot, only Le Negromant is from Ariosto of. chapter I, I above]. Ff. 65-98v Les Corrivass, comodies f. 99 a sonnet by Jaoques de la Taille;

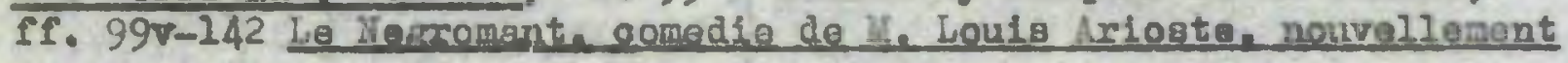

1 According to De hiaulde, Suyres de Jean de la Tał13e, vol. 3 , p. 1, the two plays flrst appeared in 1574. No 1574 adition is knom. 
Hlae en Eraneale, par Jehan do la. Tallle de Bonderer. Bound togetber, in the Arsenal copy, with other worke by Jeen and Jacques de le Taille, dated 1572 and 1573 , privilege 18 October 1570.

- do., Rouen. Du Petit Val, 1602 (B1bllothàque de Versa1lles). The sare note on the reverse of the title-pages the same titlos and follation.

Laverdin, Jaoques de, Le Celestine fldellenent repurpee, et alse on molli loure formo par Jsoques do Leverdin .... Paris, Nicoles Jonfons, n.d. [1578]. No privilego (Bibliotheque Nationale).

- La Celeatine treaicomedie. Tradult [810] d' lispamol en Fransole ... Doralere editlon. Rouen, Claude le V11lain, 1598 (Bibliothoque Nationale).

Le Loyer, Plerre, Irotopernile, ou passetemps d'amour. Eneerble une Conodle du Luet insené. Paris, Abel l'Anzelier, 1576 (Br1tioh Huseum). Ff. 64-103v le met 1naense.

-, Les aurres et merlances poetiques de Pleme le

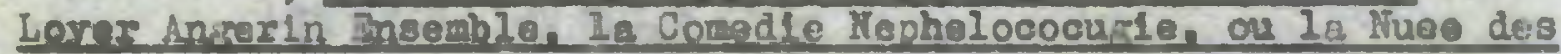
Cooua non wolns doete quo facetleuse. Parls, Jean Poupj, 1579. Privilege 1 August 1578. (Oxford, Bodlelan Llbrary; 3ritiah Huseum; Bibliothèque de l'Arsenal). Ff. 122v-160v, Le met Insense. Ff. 161-238 La oomedie Nophelococurte, ou 18 Nueo des Coous. Nephelooocuste bears the date 1578 , but to jud fe from the continuous pasination and the titie page of this edition, was probably not 13sued separately.

Mleupas, Charles, see Tumèbe.

Hesmes, Jean-Plerre de, Ia comedie des supposez de M. Lours Arlogten en Itallen at Frensors, Paris, Estienne Groulleau, 1552. Privileze 30 jeptember 1549 (Bibliothèque de l'Arsenel). 
- Comedio des supposez de lu. Lours Artoste. Italion at Bransols. Pour l'utllité de cawx qui desirent sestoir ls langue Italienne. Parls, Hierosme de Llarnef, et la veufve de Gulllavme Cavellat, 1585 (Bibliotheque de I'. rsenal). The same, re-tasued with a new title-pege. Cf. chapter I, 11 above.

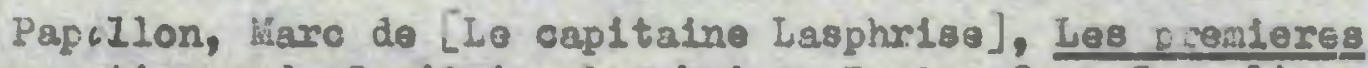
Qurres poetiques du Canitaine Lasphrise, Paris, Jean Gesselin, 1599. 2 vols. Frivilege 31 January 1597 (B1bliothèque de 1(Arsenal). La nouvelle traciconique, vol. 2, pp. 635-57.

Perrin, Frangols, Slchom nevissour. tregedle extraite du Genese trente quetrlesme Chapitre. Par Fransols Perrin Autunols. Paris, Gulilaume Chaudiere, 1589, I No privileze (Bibllotheque de 1'Arsenal, no other copy lenom). No follation before slohem 1tself. The dedication of Les escollers to Jacques arthalt is on f. $[10]$, that 1s, procedins sicher but nerertheless not applicable to 1t. A sonnet by Arthault on $f$. [7] appears to susgest that Perrin had also translated the Jephthes of Buchanan. Les Iscollers comedie, ff. 4l-73v, is not referred to on the title-page of this edition, nor has it a separate title-page. Les esoollers lo not inoluded in the 1606 edition of Slohems Slohem ravisgours, ou la

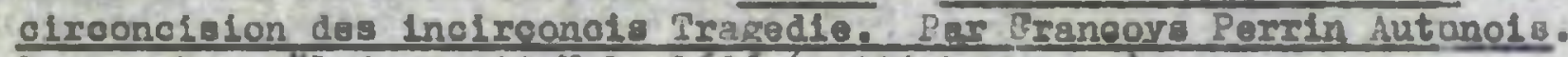
Rouen, Raphaöl du Pet1t V2l, 1605 (Brit1sh Ituseum).

Troterel, Plerre, slour d'Aras, Les corrivaur camodie facetiouse de l'inventían de B.T.S.D. Plerre Troterel Sievr d'Aves]. Rouen, Raphail du Petit Val, 1612. No privilego (B1bllothòque de l'Arsenal).

- Q1llotte, comedie facotlonse. Par le al our D. [D'Aves]. Rouen; Darid du Petit Val, 1620. No privllege (Bibllothèque de l'Arsenal).

1 La Vallière, Bibllothèque, p. 286, j1res 1586, not 1589, thus also Cloranesou, Bibllogranhlo ... P. Lacrolx in his 1866 odition of Les esool1ers and Lobèue, Thleau, p. 331. Charmasse, Mrancols Perrin, showed that this was an orror and that no 1586 edition is lonown nor have I found suoh an edition. 
Turnabe, Odet de, Les contens comedle nourelle en prose Frango18e. Parls, selix le langaler, 1584. Privilege 16 eptember 1584 (B1bllotheque de 1'Arsenal).

- Les Deszuisez. Conédie Frangoloe. Areo L'explloation des Proverbes et mota difficlles. Par Charles aupes. B101s, Cauché Collas, 1626. A second edition of Les ontens, without montion of the name of Tumebe (cited from Spector's edition of LeB contens. pp. x111-xiv. Coples in the Blbllothèque Nationale and Bibllothèque de 1'Arsenal).

Vivre, Gerard de, Comodie de le fldellte nuptiale Corapó [a10] per Gerand de Vtrre Gantols. Maletro d'esoole à Colonene. Par18, Nicolas Bonfons, 1577. No privilege (3ritiah i.useum).

Nationale). do., Farls, N1001ss Bonfons, 1578 (31bl10theque

Comale des moure de Theseut ot DLanlre.

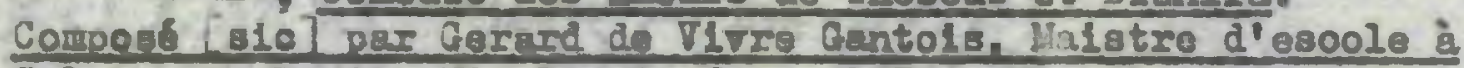
Colongene. Paris, Hicolas Bonfons, 1577. No privilogo (B1bliothèque de I'Arsenal). Dedloatory note dated 24 May 1577. Nationale).

4 , Irots comadles francolses. De Gerard de Virre Gantole. Is pzenleren Des Anourg puclaues et lorales de Theseus et Difrita 810. Le seconde De la fldelite nuptlalo dune honeste Listrone encers acn Miri et espoux. Bt la troislens, Du Patriarabe Abraham et a eervante Agar. Le tout pour lut111te de la jeunesee ot unese des esooles francoleos reveu et oorrlate par Ant. Trran. Totterdem, Jean waesbergue, 1589. Ko Privllege. The dedioation, slightly and olumeily altered to I1t all three plays, 10 the same as that of the 1577 edition of the Anours de Theseus et Jianlra, and 18. at111 dated 24 Hay 1577 (B1bliothuque de. I'Areenal). 
- do., [silut orthographical difference in title], Anvers, Gulslain Janssens, 1595. Frivilege 15 November 1589 (Blbliothèque de I'Arsenal).

-, do., [da.], Anrers, Gulslain Jenssens, 1602 (Blbllotheque de I'Arsengl, copy lacks the last few pajes \& all after Abraham $\nabla, \nabla$ ).

3. Comodles ereposed to have iven printed, but now lost.

Bourgeolo, Jacques, Comed10 tres elegante, on laquelle sont contemes los anours recroatives d'Prostrate ... et de la belle Rolirenete ...., Paris, Veuve Jeannot, 1545. Titlo jiven by La Valliere, B1bliothècue, III, p. 243. The very preolston of the title gires an assuranos that a copy was known to Le Vallidre, but none $1 \mathrm{~s}$ knom today. An adaptation or translation of Arlosto's I Supoositi.

4. Other conedies supposed to have existed in manuscrint, but nor lost. 1

Ambo1se, Frangols d' : three comedies besides Les Neapolitaines. The prefroe to tes Nespoliteines refers to "les comedies qu'll falsolt en la nyime-vere de son adolescance" and Which wore soted " "sux le thoetro olles aroient esté voijes et reoeües avec un plaisir inaiciblo", and to "plusiours belles pleces" which might be published later. La Crolx du Maine is more preolse. In his list of worics by d'Ambolse, he oltes "Trols Tragedies, quetre Comedies" (Bibllotheque, p. 87).

1 I have not inoluded in this section references to plays oalled simply "oomédie" such as the "plusieurs comedies an Irangalo" of Antolne Forestier (cf. Lebègue, Tableau, p. 292), the tern is of such general application that it covors many itinds of dramstic production other than strict comedies. References of this kind are given in full in \%. Lebegue's Tableau. 
Arost, Hlerosuie 'd' a a comedy ent1tled Les deur vourt Leanes, translated or adapted from Loys Domenichl. This comedy, acoording to La Crolx du liaine (Bibliothèue, I, 373) was ready for printing In 15843 but no copy of 1 it 18 now known, so that it appoars not to have been printed.

Baif, Jean-Antoine de : adaptations (on the lines of Le breve?) or translations (on the lines of L'eunuque?') of Terence's Fierutont1morumenos and Arlstophenes' plutas (Du Verdior, Blbliothàques of. Lebegue, Tebleau, pp. 294 and 301). Claude Blnet, in h1s V10 de Ronsard, states that Ronsard trunslated the Plutus while at the Collegre de Coqueret, where it was acted; M. Lebegue suzgasts, very plausibly, that the two translations of the plutus are ane and the same, porsibly made by Balf and ronsard in collaboration.

Boursfe, Mlohel, sleur de La Porte i two ox more comedies. Acoording to la Crolx de llaine, he wrote several trasedles and comedies in French (BlbI1othènue; of. Lebègue, Tablean, p. 295).

Chatecurloux (Cosme la Gambe) I two comedies ent1tied Lo oapltaine Bouboufle and Jodáe (Du Verdier, Blbllothòues of. Lebègue, Tablean, 9.296 ).

\section{Grơvin, Jacques, La livabertine \& see Appendlx B.}

Hardy, Alexanare, Le jalowx and possibly other comodies. Le falcux was a comedy writion by Hardy and sold by him to the troupe of Plerre Le hessier on 19 September 1625 for the our of 10011 rres toumole. For the ovidence conoerning this and possibly other oomedles by Hardy, of. S.T. Delerksur-Holsboer, "La vio d'Alexandro Hardy, Poète du Ro1", J zoceodinge of the Amorican Philosophloal Soclety, 91 (1947), 384-4013 Los ramonnours, ed. A. G111, ?axis, 1957, 90. IVi11-xovili.

Jodelle, Etlenne, La renoontre. E. Balmas, in his edition of L ' rusene, pp. 6-8, hais shown that the 1dentification of L' innene with La rencontre, first made by the Iroses Parfaict (IIstolre du thétre francis. III, Parls, 1745, p. 290), is an error. La renoontre 
wae a separate comedy, acted together with the tragedy Cleopattre In 1553, and now no longer oxtant.

Larivey, Plerre de; three comodies. The title page of the 1611 edition of La canstanoe, Le fldelle and Les tromperles, implies that these are only three out of $81 x$ further plays by Larivey: Trols comedies des alx dernleres de Plerme 3 Lartver Chempeno18. The dedloation to Franools d'Ambolse con Irms th1s. Three others, therefore, may be presumed to have existed, but were nover printed.

La Tallle, Jacques de; ane or more comedies. Jean de 1a Trille, In his Sell le Nurieux, Paris, Federio Morel, 1572 , f. 70, writes of his late brother Jacques that he wrote "oorme moy (seicin lo vray art, et la fagon antIque) Poëmes entlers, Tragedies et Comedies, en 1 's ge de 16,17 et 18 ans", and that among his papers he fourd five tragedies and one comedy. In the same volume, a number of moriss by Jaoques de la Tallle are printed, wh a title pase ( $f$. 74) by Jacques de la Taille bimself where he says that he may aftervards publlsh his "Trajedies, Comedles et autres poëmes nouveaus".

Laudun, Plerre de, d'Algallers one comedy. In hts Art Poëtlque Franonis. Paris 1597, V, 1, he writes "J'ay falot quelque comedie que l'on pource volr, si jo la mets chez I'imprimeur, toutesfole je $x^{\prime}$ en suls suere en deliberstion. Plaute et Terence en ant falot en Latin lesquelles on pourse veolr et quil serviront de patran." The mention of Plautus and Terence Lmmediately after montion of his "comedie" susgests that the pl.y was a cenuine comedy and that the word "comedle" is not used in the more general sense of "plav".

Le Breton, Gebrlel: two or more comedies, ane of which was ontitled Lo ramonnour. La Croiz du Haine, 3ibliothoque. I, 143. writes of "plusiours autres trajodies et comedies srangolses" by him, Du Verdier, Bibliothòque, p. 429, montions anly ane comody anu that antitled Lo hamanngur. Cf. Les remonnours, ed. A. C1ll, Paris, 1957, p.x. 
Pontowx, Claude do: throe comedies. Du Verdiler atates that he left in manuscript "dewr tragodies et trols oumedies, acooinmodees sur les Ilstolres de nostre temg" (Blbllothdouse) of. Lebague, Tablean, p. 294).

Ronsard s see Balf.

Tumèbe, Odet de a mamusoript ooples of Les contens, made from the 1584 editton. "Flusieurs s'on sont fait arec Grand labeur des coples à la main", viltes Charles haupas in his Epftre to the 1626 edition of the play (seo section 2 above).

Vivre, Gerard de: The dedication of the 1577 edition of Les amours de Thesens et Dlanirs cells the play "une Comedie dee premleres de ma composition", auggesting that he may have written others besides this and La fidel1te nuptiale (also published in 1577).

5. Ladern editions.

Items marked + are those used and olted in the tert of this thools sithout further precision.

\section{Collectlonss}

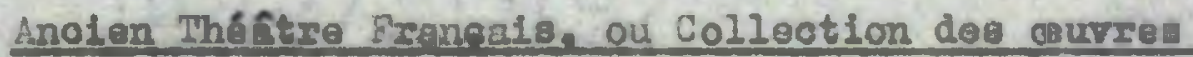

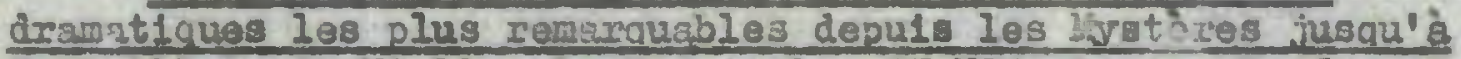
Comellle, ad. Viollet-lo-Duc, vols. IY-VII, Paris, P. Jannet, 1854-6. Jode110, L' Llakene, IV, 5-81; Grévin, Los esbahia, IV, 223-333; Bolleau, La roconnue, IV, 335-438; +tharivey's nino plays, V, 1-VII, 105; Tumebs, Les contens, VII, 107-231; Q'Ambolse, Lns Heapolitaings, VII, 233-333; + Codard, Les doszulaez, VII, 335-462, Frapilion ito oepitaine Iasphrise], ia nouvelie trazi-comique, VII, 463-91.

Le thaftre franeglas gu XV10 at au XVIIe släolos, ou oholx des conédies les plus curlousen antérlouros à Hollere, ed. E. Foumier, Paris, 1871, 8 (reprinted in two 16mo rolumes, 
Par18, 1872). Jode2le, L' uzène, 1-243 Belleau, La reconnue, 25-54i Larivey, Les esprits, 55-09; Turnobe, Les contens, 90-131; +td'Ambolse, Ies Neapoliteines, 132-65, t+ Perrin, Les escollers, 166-91, Líntluc, la comédie de proverbea, 192-2273 Du Peschler, La comédie des comédies, 235-56; Du Ryer, Les vendenges de Suresnes, 319-473 Malret, Les zelanterles du Duc d'ossonne, 373-99.

Separate editions:

+tAnon, La Tasse, ed. P.L. Jacob, Recuell de plèces zares et facótleubes, rol. III, Parls, 1873.

Balf, Jean-Antoine de, Uurres, ed. Ch. liarty-Laveaux, v01. III, Par18, 1886 (Le brare, pp. 183-373).

++Belleau, Remy, churcer poétlques, ed. Ch. Marty-Laveanx, 2 rols., Fo.rls, 1878 (La reoconmule, vol. 2, pp. 355-451).1

Bruno, Glordano, Il Candelalos reprinted, tozether with the 1633 adaptation Bontswoe et 10 pdent, in Ir Candelaso di Glordano Bruneo soniface et lo pédent comédle en prose iafíté de I'Itallen de Bruno Nolano, ed. V. Imbriani, Naples, 1886.

Comeille, Plerre, ${ }^{4+}$ islite, ed. Marlo Roques and karlon Ilèvre, L1110 and Genere, 1950.

Grévin, Jaoques, Thếtre complet et poésles cholsies, ed. L. Pinvert, Par18, 1922 (La tresoriore, 51-1133 Les esbah1s,

1 The so-called Curres complètes of Belleau, ed. A. Couverneur, 2 vols., Par18, 1867, do not inolude La reconnue. 
115-217). Cf. 2180 P.R. Augu1a, Las poètes fransolo depuis lo XIIIe alècle jusau'i Lalberbs, Parib, 1824 (La troporiere, vol. $\nabla$, $203-76)$.

+Jodelle, Etlenne, Ll Lukène, ed. B.H. Balmas, Tur1n, 1955.

+t La Tallle, Jean de, Guvsee ed. R. de Llaulde, 4 vols., Par18, 1878-82 (Les corrivaux and Le nogromant are in the rolumes ent1tled Comsdies, 1879, pp. III - CVI and CVII - CCXXVII respeotively).

++Le Layer, Plerre, La Néphélocoouste ou la Nú́e des coour, oosdie, ed. G. B runet], Turin, 1869 (11mited edition of 100 coplas). Nelther of Le Loyer'a plays is in Cuyres postiques de Plorre le Lover, ed. M.J. Turquals, Angers, 1934.

Perrin, Franpols, Les Esooliers, ed. P. LLacrolx], Bruosels, 1866 (12mited odition of 106 ooples).

++Iurnòbe, Odet de, Les Contens, ed. I.B. Spector, 2nd edn., Faris, Socisté des Textes Frangais Wodermes, 1964.

6. Wodern adrotations.

Camu, Albort, Les Isprits oomédie adaptation en trols aotes par Abert Cames, rar18, Gallimard, 1953. Adapted from Larivey's Les esprits written in 1940, acted in 1946 in 4 Igerla, romodelled for the Festival d'art dranatique d'ingers, 1953.

Philippon, Gustave, La 1'résorière, L'Ideale-ievue, 25 November 1911. An adaptation in three acts of Grévin's Le tresorière. 
7. Seoondaris sources

Atkins, J.W.H., Snglish 1iterary oritiolgm a The Renasoence, London, 1947.

Attinger, Gustare, I'asprit de la conmadio dell' exte dens le thếtze framanis, Parli, 1950.

Baldrin, T. W., W11110m Shakgoere'a Plve-Aot Structure, Urbana, 1947.

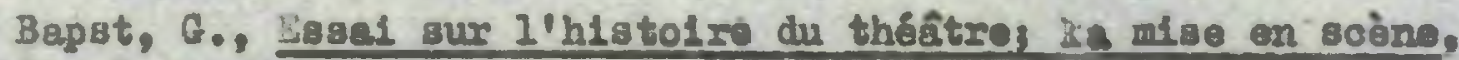

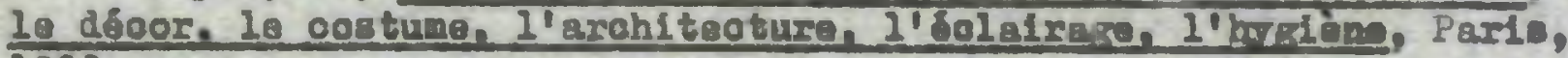
1893.

Baschot, A., Lei oomidien itallans i le oour de France sour Charles IX. Honst III. Hearr IV ot Louls XIII, Parls, 1802.

Beare, 览., The Roman stage, 2nd odn., London, 1955.

Botasso, I., "Lo Commedie 11 Lodorioo Arlosto nel teatro Irancese del cinqueoento", Olornale Storlco della letteratura itallans, CXXVII (1951), 41-80.

Boughner, D.C., The Braxgart in Bonal ssanoe Conady, A study in Comparative Jrama from irlstophanes to Shakespoare, Minneapolis, 1954.

Bowon, Barbara C., Les agrsctórlatloues essontlellos de is farce frangel se et leur survivanoe dang lel abnéce 1550-1620 (IIIInols Btudies In langrage and 11terature, 53), Orbans, 1964.

Bradbrook, U.C., the Browth and structure of Ilizabethan oomedr, London, 1955.

Brow, H.L., Musio in the Frenoh eooular thester, 1400-1500, Cambridge (liass.), 1963.

Cannings, Barbara, "Towards a definition of farce as a 11 terary senre", hodern Lancuave Revier, LVI (1961), 558-60.

Castor, Grahame, PlGlade poetios, Cambridgø, 1964. 
Chamard, Henrl, Josohtm du Bellev, Lille, 1900.

, Históer de la Plélade, 4 rols., Parls, 1939-40.

Charmasse, A. de, irangols Perrin, poète frangate du XVIo slècle. Hemolres de la Soclété aduenne, nouvelle serie, 15 (1887), pp. $1-250$.

Chasles, E., La comsdie en France au XVIe slècle, Par1s, 1862.

Clorsnescu, A., L'Arloste on Yranoe, 2 vols., Parls, 1938.

du seisleme sloole, Parls, 1959.

- Blbliorraphle de la littérature frengalae

Clubb, Loulse G., Giambathista Della Forta drematist, prinoeton, 1965.

Cohen, G., "Honsand et le th6âtre", Helanges of ferte à Henrl Chamard, Par18, 1951, 121-4.

- Le th8stre on Pranoe au moren-ege, Par1s, 1948.

Couzan, I., Des reorêsentations dramatiques ot partloullièremant de 18 comédie politloue dans les 00118zes, Paris, 1859.

Dabney, I. I., Mrenoh dramatlo literature in the relen of Henrl IV, Austin, 1952.

Daley, T.A., Jean do 1 e faille (2533-1608), Etude historlaue et 11ttéralre. Pard8, 1934.

Doougdi, 8 . and Roymond, S., Le décor de thêtre on Franoe, Paris, 1953.

Delerkauf-Holsboer, S. Wlima, "ha vie d'Alexandre Hardy, Poot to du Hol", Prooeedinge of the Amerioan Philosophlosi Soclety, 91 (1947), 328-404.

De Laudun, Plerre, d'Algallers, Art Poëtique Frangols, Par1s, 1579.

Dietsohy, Chexlotte, Dle "Dame d'Intrigue" In der franzöglachen Ortinalkomöule des XVI und XVII Jahrhunderte, Halle, 1916. 
Droz, I., and Lewlaks, H. (ods.), Le reoue1l Trepperel : Los feroes, Genera, 1961.

Du Belley, Josohim, La Defsonoo et 113uetration de la langue Ecancorse, Par1s, 19593 od. H. Chamard, Parls, 1943.

Duohartre, D., Le ooméde itellenna, Par18, 1924.

Duohartre, P.I. (ed.), Roouell de Dlusloure fraraants des premières coxidios itallonnes an dit Peouell de Possand, Paris, 1928.

Duokworth, 0.E., The nature of Roman coredy. A study in popular ontertainment, rinoeton, 1952.

Du Verdier, intolne, 31 ibliotheque, Lyon, 1585.

S1110-Formor, One, The Jacobean drams, London, 1961.

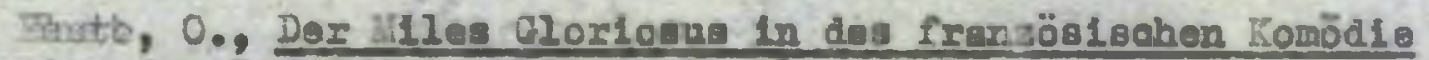

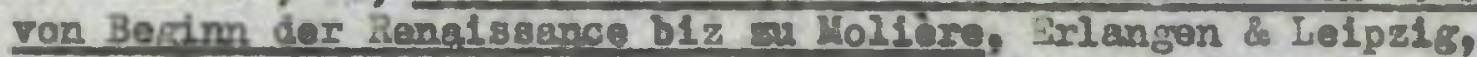

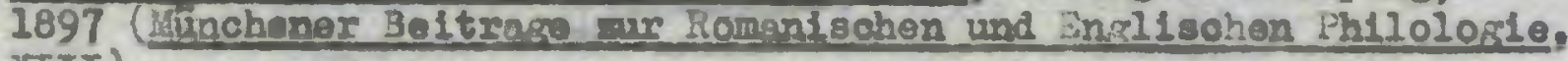
XIII).

Frank, Graoe, tha modieval Fremoh dram, Oxford, 1954.

Gudoffre, Gllbert, "L'univaralté colléglale et la Plélade", French Studies, XI (1957), 293-304.

$$
\text { - Ronsard par lui-nôn, Paris, } 1960 .
$$

Garapon, Robert, La fantalale raxble et le comlque dans le thiftre franghds, Faris, 1957.

Gorflot, L., Le thistre au collère, Parls, 1907.

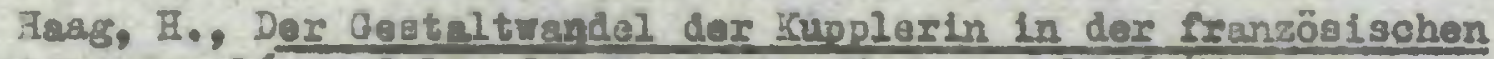
L1 terature des 16. und 17. Jehishunderts, Larburg, 1935 (Marburger Belfrege zur zomanisoben Philolorde, XVII).

Haressti, Jules, "La 11ttbrature dramatique eu temps de la Renal ssanoe", Revue d'hlstolse litteralre de la Brance, XI (1904), $680-6$. 
Haxtert1, Jules, "La oon\&dle frangaise de la Renalssance et la scène", Lenue d'guatolra Ilttéraire de la Brunce, XVI (1909), 285-301.

Horrlok, H.T., The fuslon of Horatian and srlatotellan 11teracy or1tio10m. 1531-1555, Jxbans, 1946.

- Comile thoosy in the sixteenth century (IIIInols studies in Irenguas and I1terature, XXXIV), Uxbens, 1950 reprinted aeparately, Jxbana, 1964. 1960. - Itallan comedy in the Fensisance. Unbara,

Hindley, A., The derelopment and diffusion of faree in Franoe towardis the ond of the rifidle Aces (unpubliahed dissertation for the degree of Ph.D., Univeraity of Hull, 1965).

Holsboer, S.T., Hlatolre de la mise en soène dans le thôtre franale de $1600 \times 1651$, Parle, 1933.

Hoxa-nilonval, H., Trednotions ot adantations frangaises du thóatre ftranger, vols, 1, 2 and 3, Par18, 1958, 1959, 1960.

Huguet, 2., Dlot lomnalre de la langue frangalse du $16 \mathrm{e}$ slèole, Parls, 1925 - [In proscess].

Erde, M.C., Plavwriting for Blizebothens, New York, 1949.

Jacquot, Joan (od.), Ia vie thîtrel au tempe do 18 Renaissange [oatalogue of an exhibition], Paris, 1963.

Par1s, 1964. - Le Ileu thâtral è la Ranaisaenoe.

Josoph, B.L., Blizabothan acting, Oxford, 1951.

Kindermann, H., Thoeterreschlohte Juropas, vols. II-IV, Salzburg, 1959, 1959, 1961.

Kohler, P., L'esprit olassicue et la coaldie, Paris, 1925.

La Cro1x du Lalne, Tranpois Grudf, siour de, B1bliothèque, Paris, 1584. 


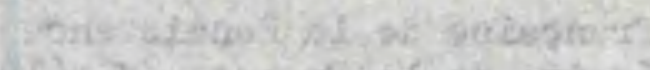

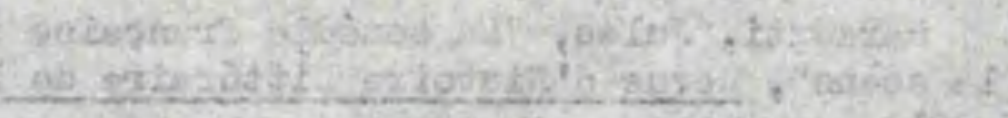

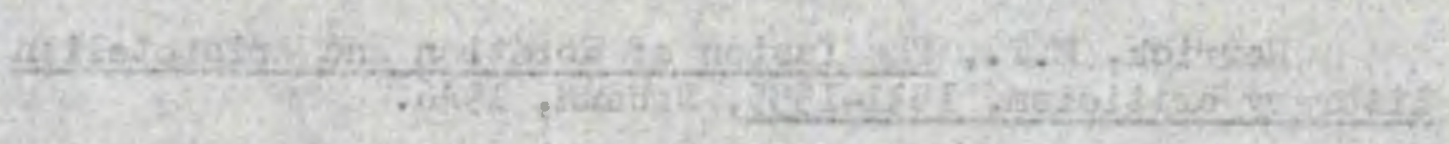

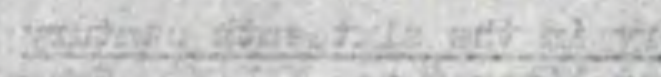

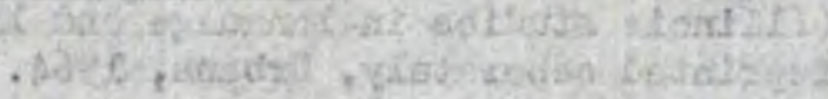

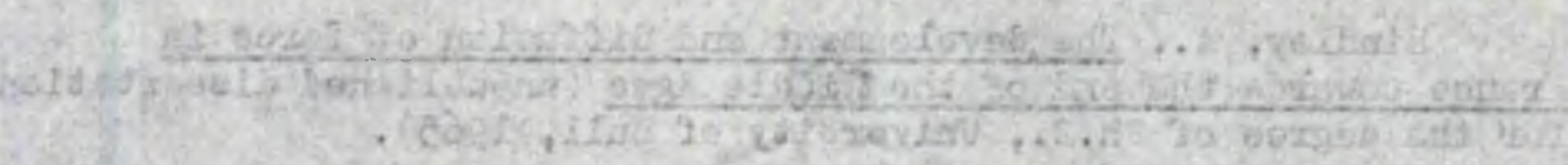

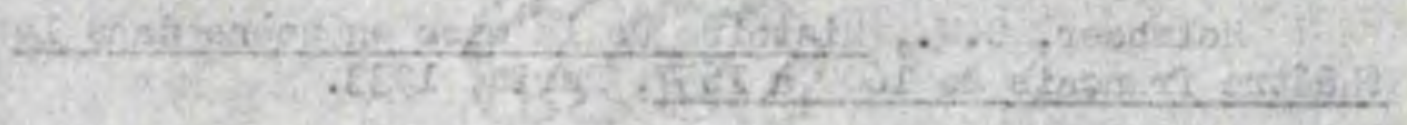

Lauton, H.W., "La survivance des personnages teventiens", Balletim

de l'Assoriation Gillame Budé, 1964, 85-94.

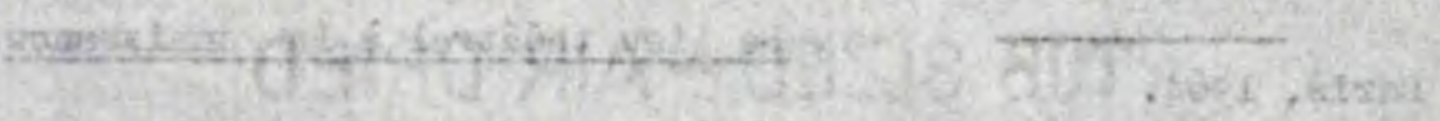

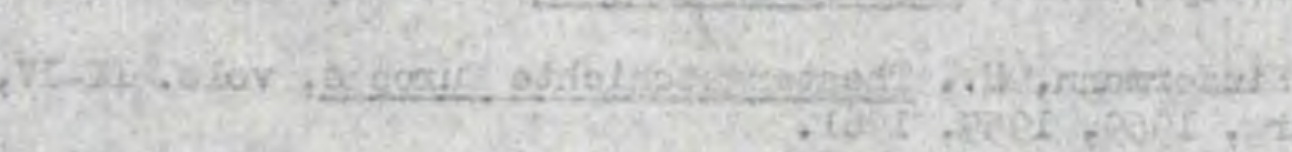


La Frosnaye, Plorre Vauquelin do, L'Art jootlque, Parls, 1605, ed. G. Pellissler, Parts, 1885.

Lanoastor, H.C. (ed.), Ie Mbolro de liaholot, Lelurent ot d'artras déoorsteurs de I'Hóte de Boursosne, Parle, 1920.

- Alatozr of French dramatio 11tercture En the serenteenth o entury, 5 parts, Baltimore, 1929-42.

¿a Vallìre, Btbliothèue du thêtro fransolo depuis son irlolne, 3 rols., Dresden, 1768.

Larronson, T.S., The Prench stage in the serenteonth century, Manohester, 1957.

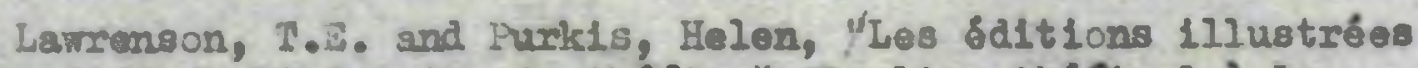
de Térence dans l'htstolre du thétrs", Jo lieu thétral à le Renalseance, ed. J. Jacquot, Par1s, 1964, 1-23.

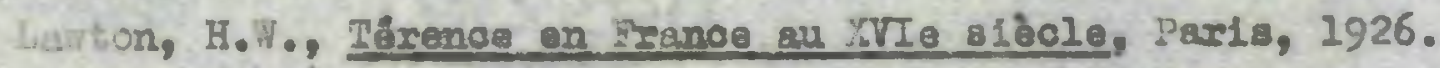
soir10- 510010, XIV "(1927), 336rarl. theory, Lanchester, 1949.

- Lea, K. I., Itallan popular comedy : study in the oompedie del1 Arte 2560-1620. Cxford, 1934.

Lobègue, Raymond, "Tableau de 1 e conbdie frang̨alse de la Renalssanoe", Blbllothlaue d'hurganlame et Rensiseanse, VII (1946), $278-344$.

, "Ia comódie Itallenno on France an XVIO siècle", Rerue de Littśrature Comparće, XXIV (1950), 5-24. France", Rivilate di' atudl tertril, 9/10 (1954), 71-7.

, "W'Influence des romanolers sur 108 dramaturges frangals de la flo du XVI0 s100le", Bibllothocuse d'juranleme et Renaisganoe, RVII (1955), 74-9. 


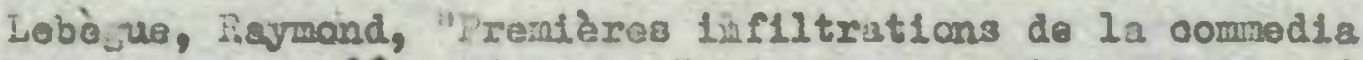
dell'arte dans le thétro Irangals", Cehlers de l'Assoolation des Etudes Fransedses, XI (1963), 165-76.

- "Unité et pluralité de liou dans le thêtre frangals", Le llou thchtral à la Renalssanoe, ed. Jean Jacquot, Parls, $1964,347-55$.

Leroux, P.J., Dictionnalre comique, astyrlaue, critlaue, burlescue. I ibre et iroverb10l. Pampelune, znd edn., 1786.

Leroux de Linoy, A., Le litre dee proverbes frangsts, 2 volo., Par1s, 2nd odn., 1859.

Ila de lalkiel, H.R., "Ml fanferrón en el teatro del Rensclmiento", Romanoe Philolosy, XI (1957-0), 268-91.

Maxwell, Ian, Prench Farce and John Herroad, Melbourno, 1946.

Mignon, Kaurice, "Les Influences 1taliennes dans la oombdie frangalse de la Lenalssanos", Revue des Cours ot Conferrenoes, XX $(1911-12), 354-60$.

Hongrédien, G., Dictlonnalre blosraphlque doe oomfdiens Exansa1s du XVIIe slèce, Faxis, 1961.

Morln, Louls, Les trols Plome de Lar1vey, Mroyse, 1937.

Houssinac, Leon, Le thêêtre, Farks, 1957.

N1coll, Mllardyce, Maks, mimes and mireles [1931], Hew York, 1963. - The world of Yarlequin, Cambridze, 1963.

Pasquier, Stlonno, Les secherches de 18 Eranoe, Paris, 1611.

Paterson, W.F., Thxee eanturles of Srenoh poet 10 theory, a exitioul hlatory of the chief arts of peetra in france (1328-1630) (Jniversity of mohifan ublications in Languaze and LIteratire, XIV-XV, 2 vols., Ann Arbor, 1935.

Peletler, Jacques, du Mans, i'Art Yoëtlque, Lyon, 1555. Ea. B. Boulonger, Faris, 1930. 
Ferman, R.C.D., "The influonoe of the corimedla dell'arte on the French theatre before 1640", Fronch Studles, IX (1955), $293-303$. $1906-7$.

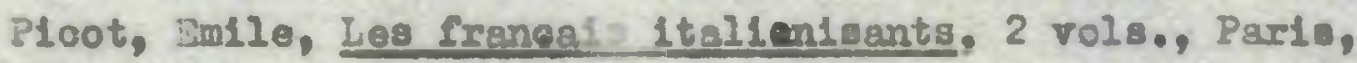

Pinvert, L., Jsoques GrSvin, Parls, 2899.

Purkis, Helen, "Les intersiòdes à la oour de Grinoe", Blbllothòqu d'Humenlone ot Renalseanoe, XX (1958), 296-309.

fietermanis, J.3. and Imwin, W.R., the conlo atyle of Berumarchale, Seattle, 1961.

Rayasiguler, Def, [Preface to] L'Aminte du Tasse,

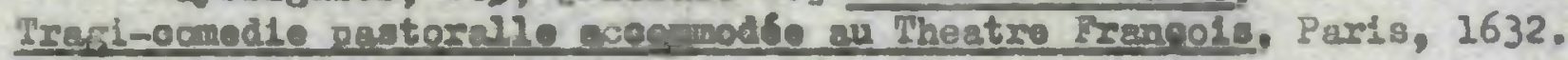

Figna, I., Alerandre Hardy ot lo thêtre frangete ì la fin

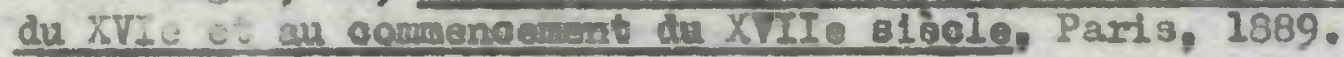
, "Les personnages oonventionnels de la combde au XVIo 81èclo", Feven d'bistolre 11ttéralre de le France, IV (1397), 167-79.

Paris, 1901. - Le thêtre franealo arant le pórlodo olessiaue, - De Jolalle i Mol1exe, Paris, 1911. [1936].

Rivallle, Loulo, Ies dobnts de P. Cornellle, Paris, n.d.

Robbins, E.W., Drasatio chargoterization in printed comentariee on Termaen 1473-1600 (II1Lnols Studies in Lanzuage and Literature, XOXV), Uxbans, 1951.

Roy, Donald, Conditions ard conrentlons of the early sevonteenth century thestre in ranoe (unpublishod dissertation for the decree of .4..., University of irales, 1954).

Roy, Bmile, "L'avare de Dont et L'avare de Hollère", Reve d'uletolre Littsrelre de Ia France, I (1894), 38-48. 
1909.

Saulnier, F., Le parlement de Bratarne $255-2700$, Remnes,

Soallger, J.-C., Poetloes librl sentom [iyon, 1561], Heidelberg, 1607.

Soherer, Jacques, Le dremsturrí olasslque on Dranoe. Parls, 1950.

- Lo dragsturste de Beaumarchais, Perto, 1954.

Sohwartz, I.A., The eorid da dell' arte and Its infucase on Pronch oomedr in the 17 th ocntrow, Now York, 1933.

Soblllet, Thomas, Art Poetlou, Frangore, Parle, 1548, od. F. Gatffe, Paris, 1932.

Serlio, Sobastiano, Il nximo libro d'erahltotture [I]

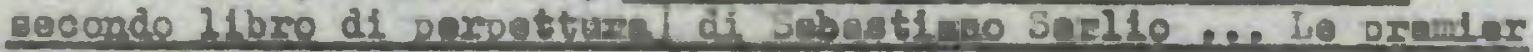

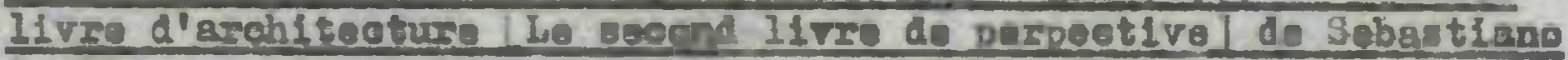

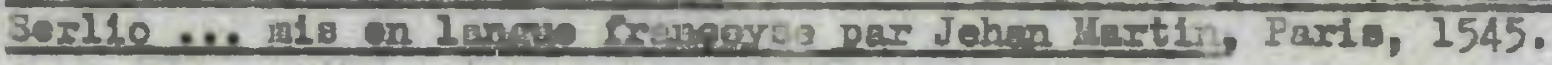

Spector, H.B., "Odet de Tumbels Les Contens and the Itallan comod", Breach Strdies, XIIII (1959), 304-13.

Sterling, C., "Warly painting of the Commedls dell'arte In Branoe", Bulletin of the Liptropolitet Huseure of Art, Now York, 1943, Pp. 11 II.

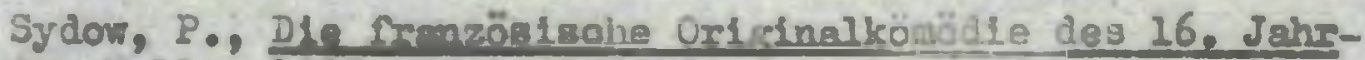
hundert8, Halle, 1908. s.d.

Tabarin, Guverede Trbarin, od. O. d'Harmonville, Paris,

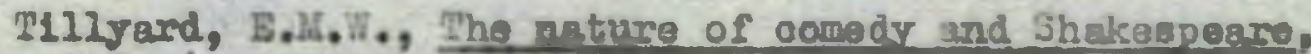
London, 1958 (The English A8sociat1on, Prosicontial Address, 1958).

Toldo, Pletro, "La conédie frangalse de la Ronalssanoo", Revue dulisotolre Llttéradre de la Pranoe, IV-VII (1897-1900). 1617.

Vlonler, N., Hlatolise de la maibon de Luxambourg, Parls, 
1960.

Vyvyan, John, Shakespeare and the Rese of Love, London,

Nolnberg, Bernard, Grittion prefeoes of the Frenoh

Remalosanoe, Eranston (IIIInols), 1950.

Wiley, T.L., The early publio theater in Franoo, Cambridge (Lass), 1960.

Iates, Prances, Contribution to the study of the French 90018 drams in the eixteenth oenturn (unpublished thesis for the dogree of U.A., London, 1926).

Cambridase, 1936.

- A atudr of Lore's Labour's Lost,

London, 2964.

Glordene 3 mune and the hormotic tradition,

Young, llargaret L.J., Gat11 louphe Dee Autels (Travaur d'Humaniano ot llenalssance, XIVII), Genove, 1961. 
A C T E PREMIER.

SC $\mathrm{E}: \mathrm{t}$.

L Y Y S, RICHARD.

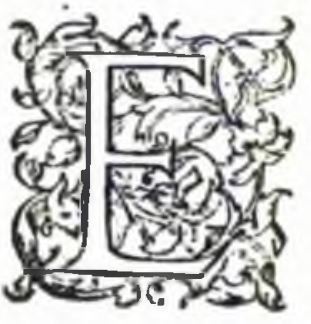

I bien Richard, quelle nouselle

apporres- 1 u de ins Cruelle?

vesidt-elle dǘngue effre roufrours

Ainfip a oureufe en fes amours?

Richard.

Möferer se cron que ls paumetre

Sans aucun repor noes foubaitre

Loys.

Entre for bras, woule a wo" mienx"

ze penfe may que cous les Diesce

Prennent plaifir en mon marrire:

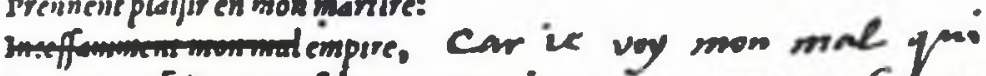

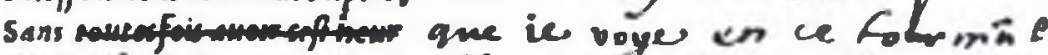

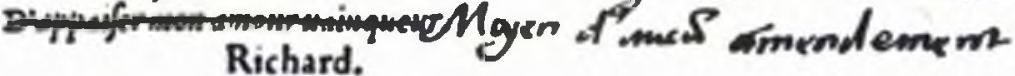

Non non, monfieur, iny eßpersace

Que nous ell arurez ioüi/fance

En peu de cemps. LaIfer moy feire

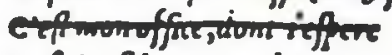

sufnimfs been inon dewoir.

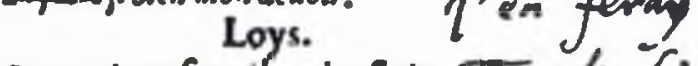

Ece croyezquepour vous cof

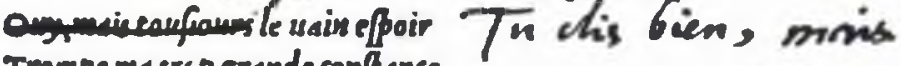

Trompe and trop grande conftence

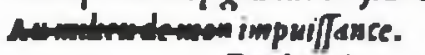

Richard.

Praymene une telle bcauté

a buen un amans aerité:

Q

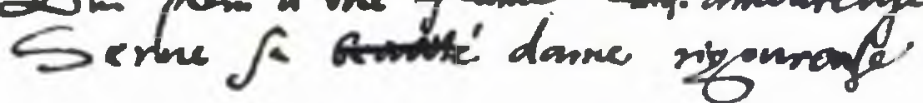




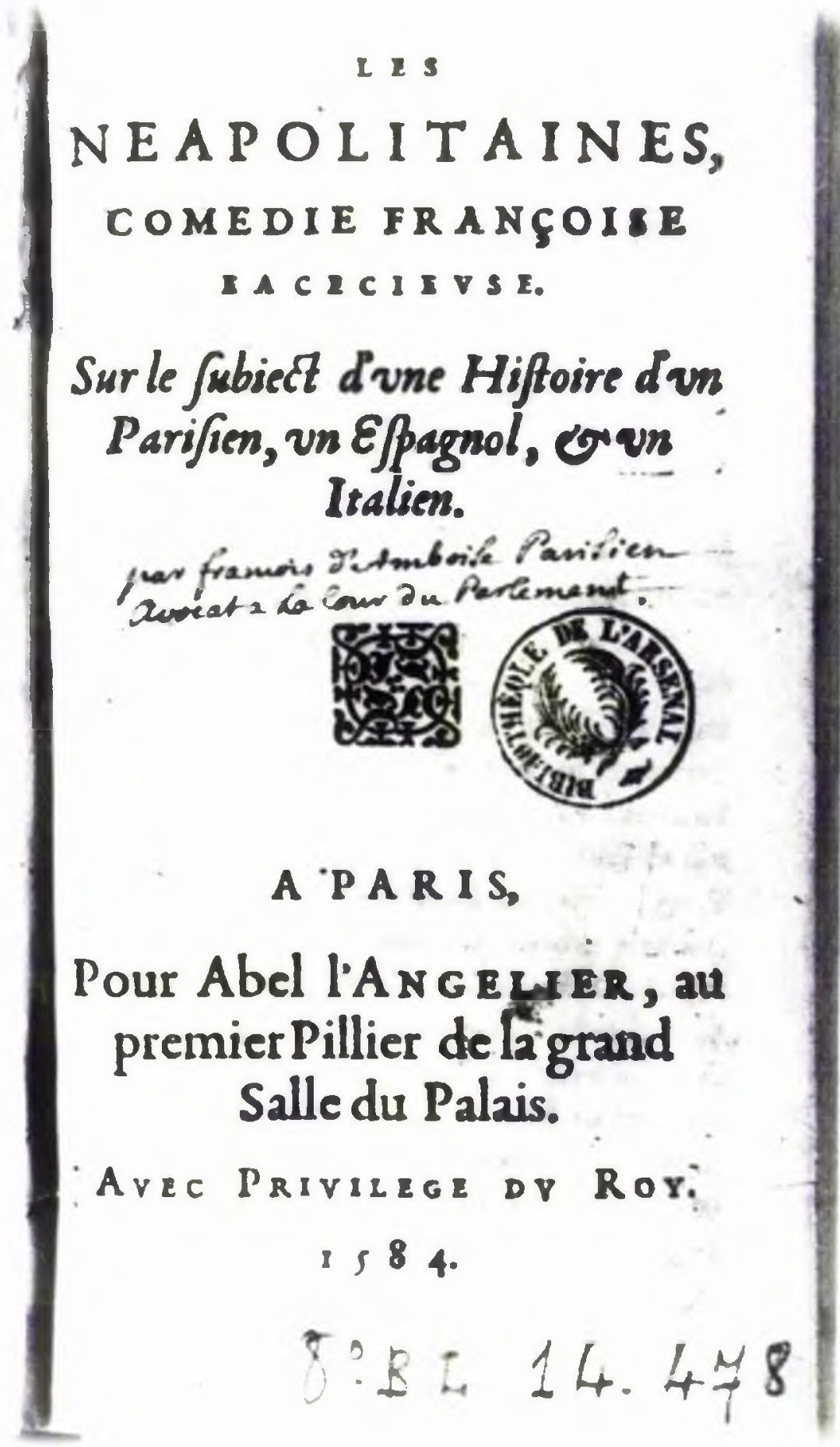




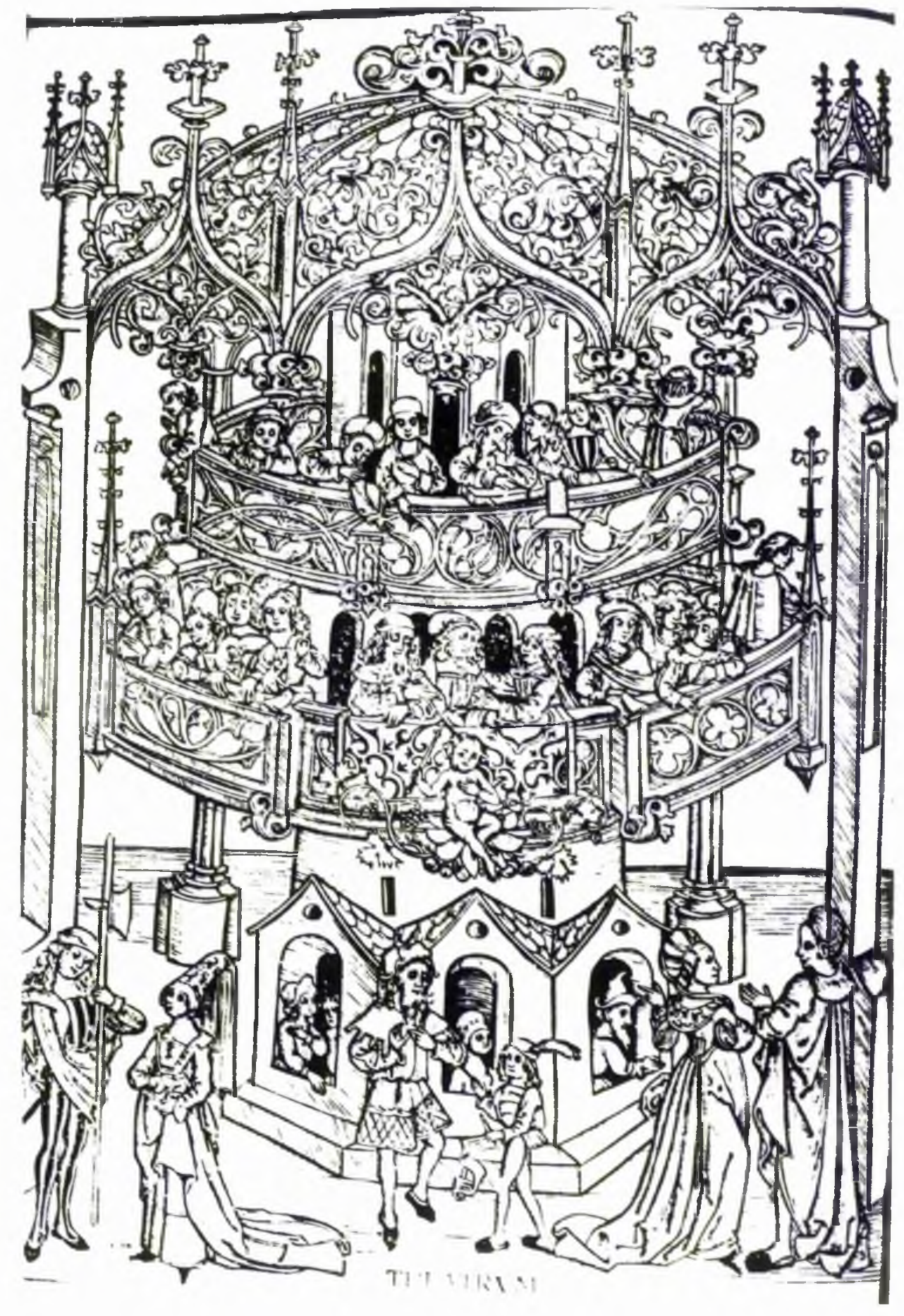




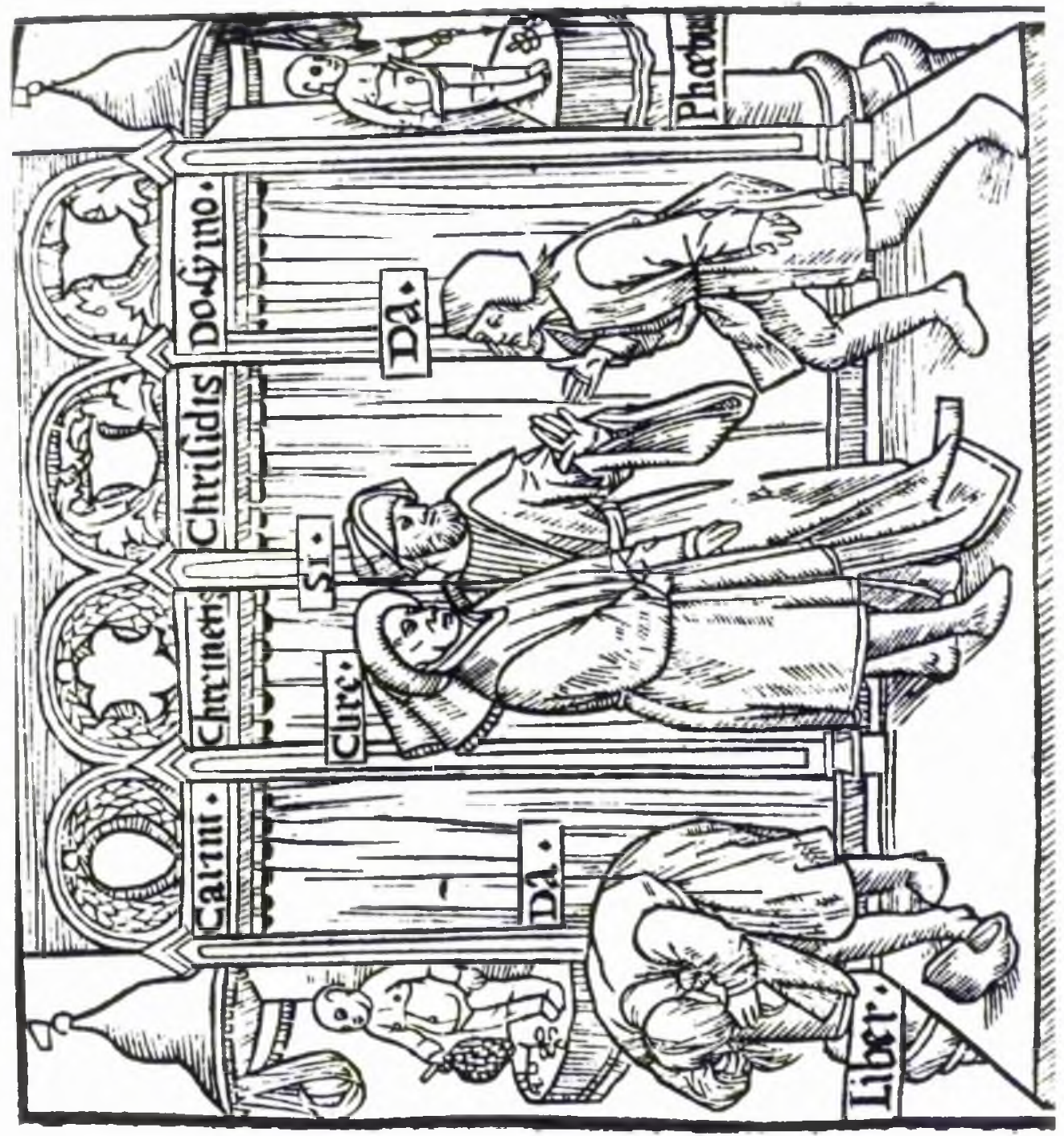




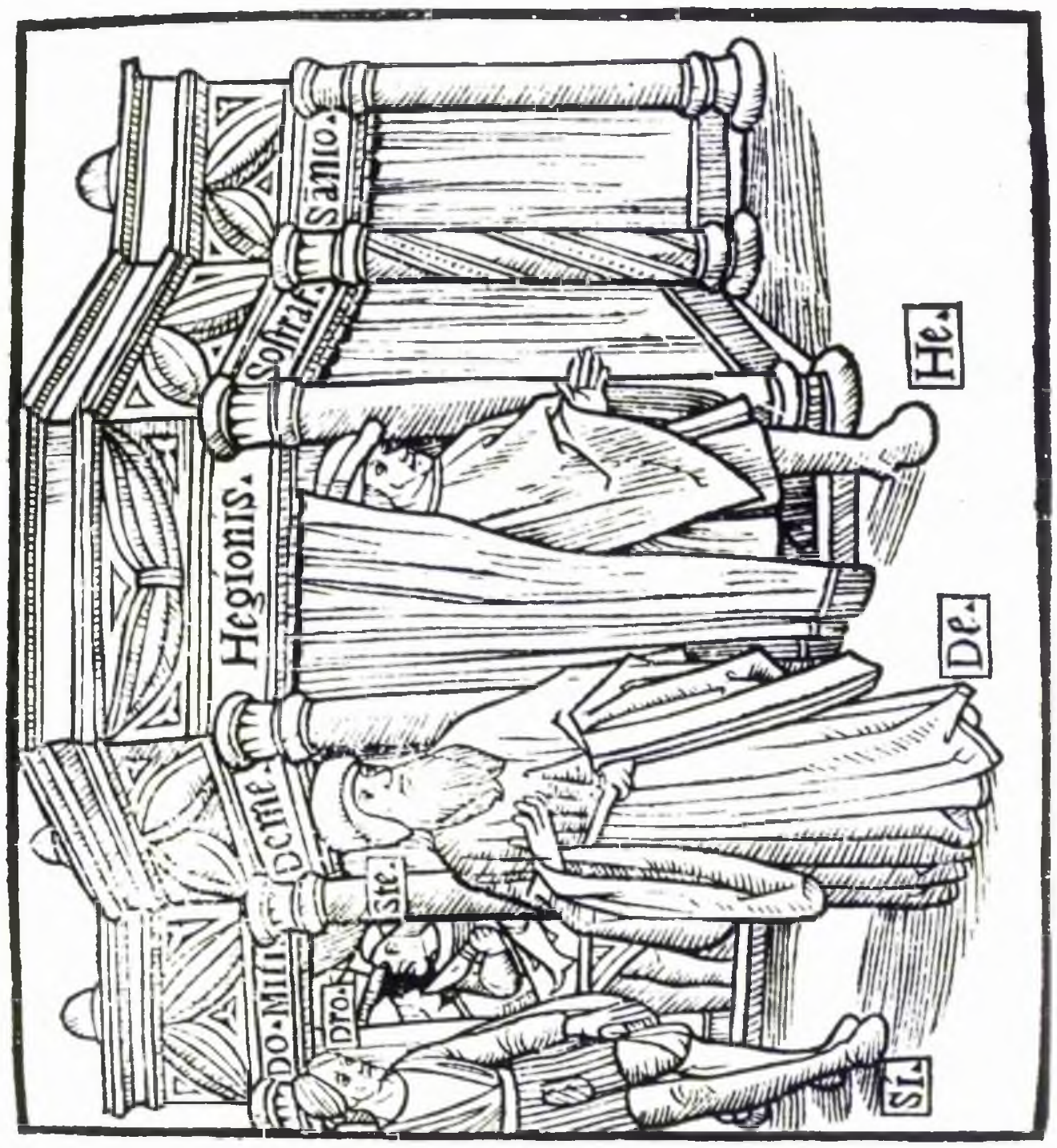




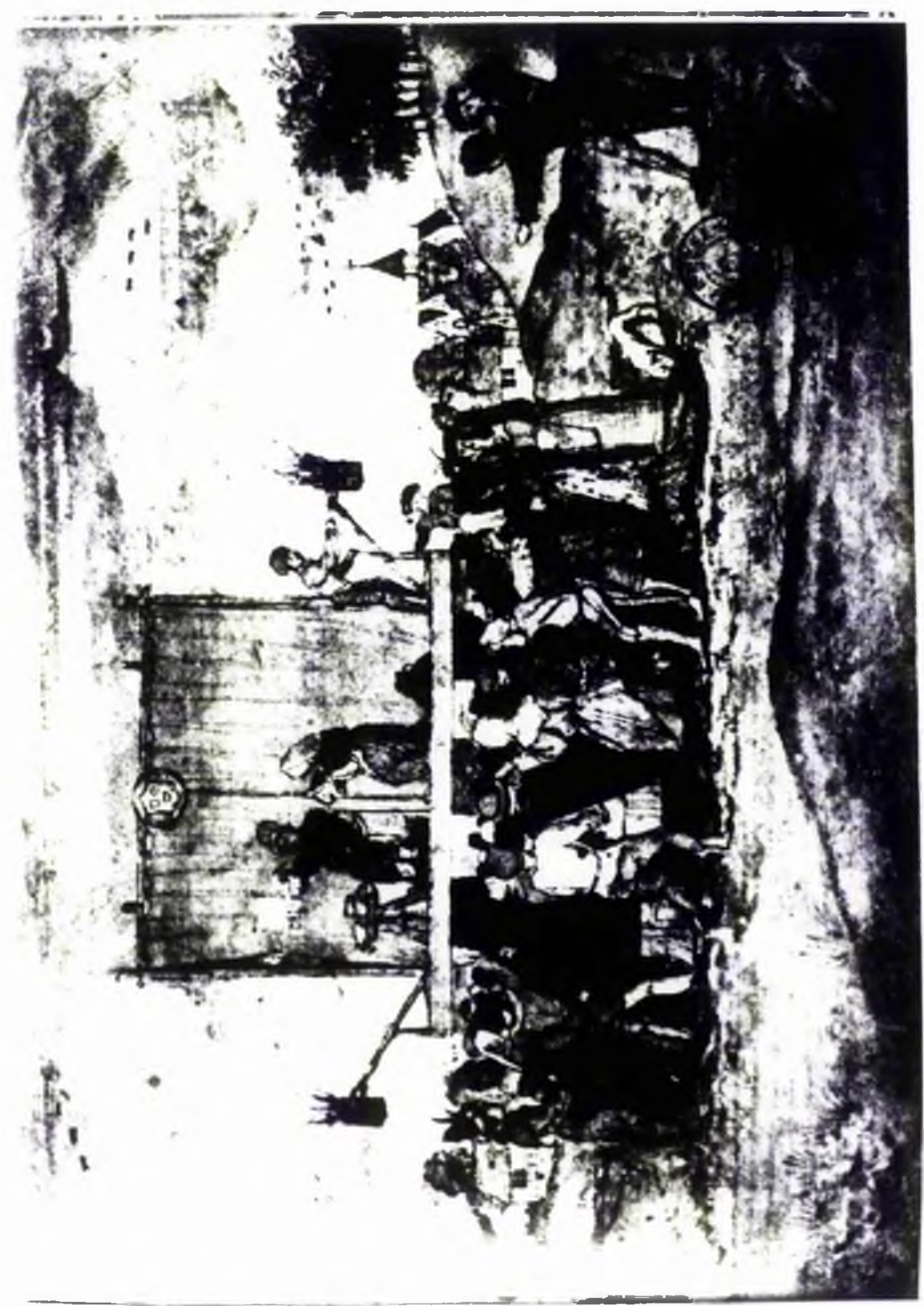




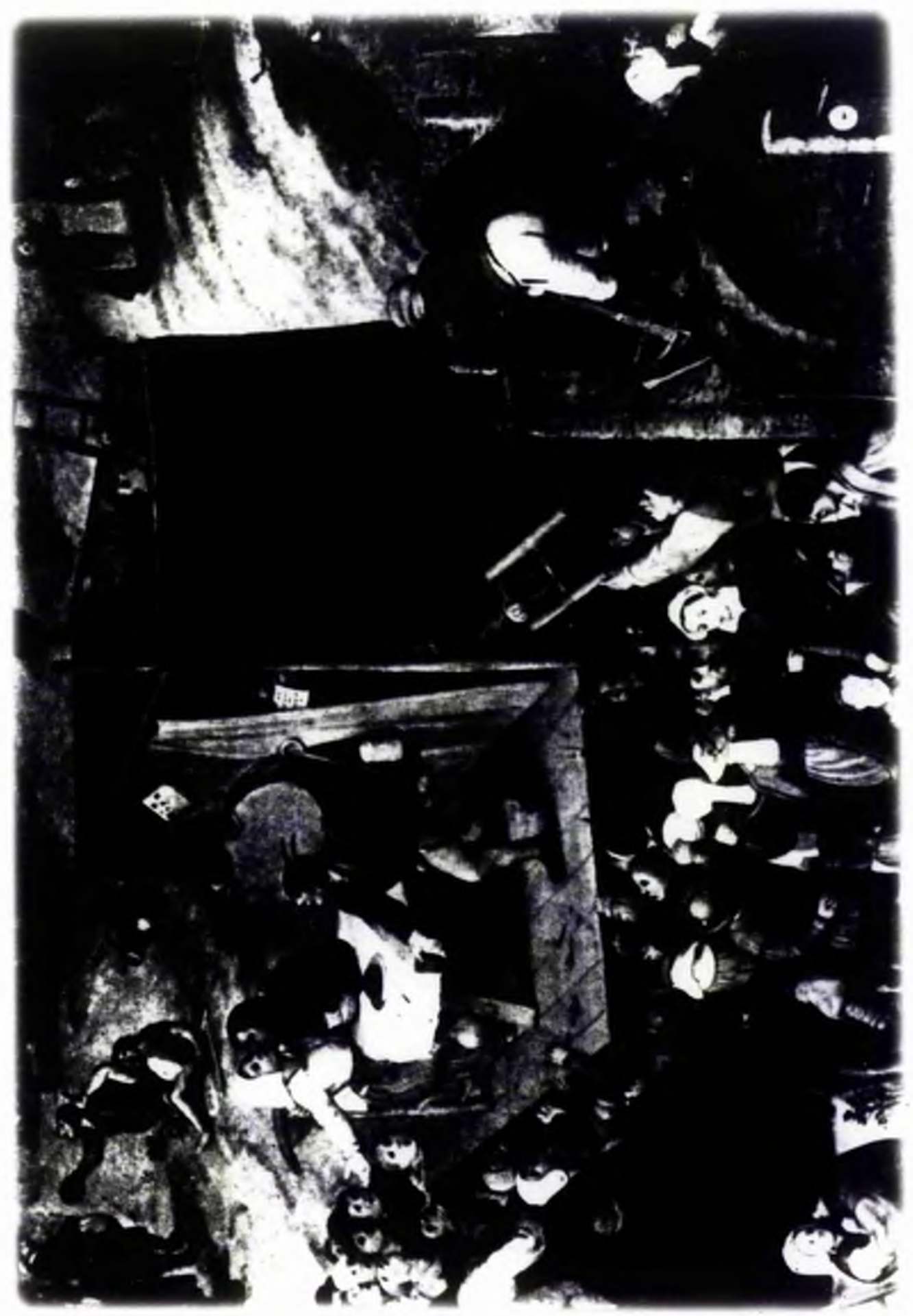




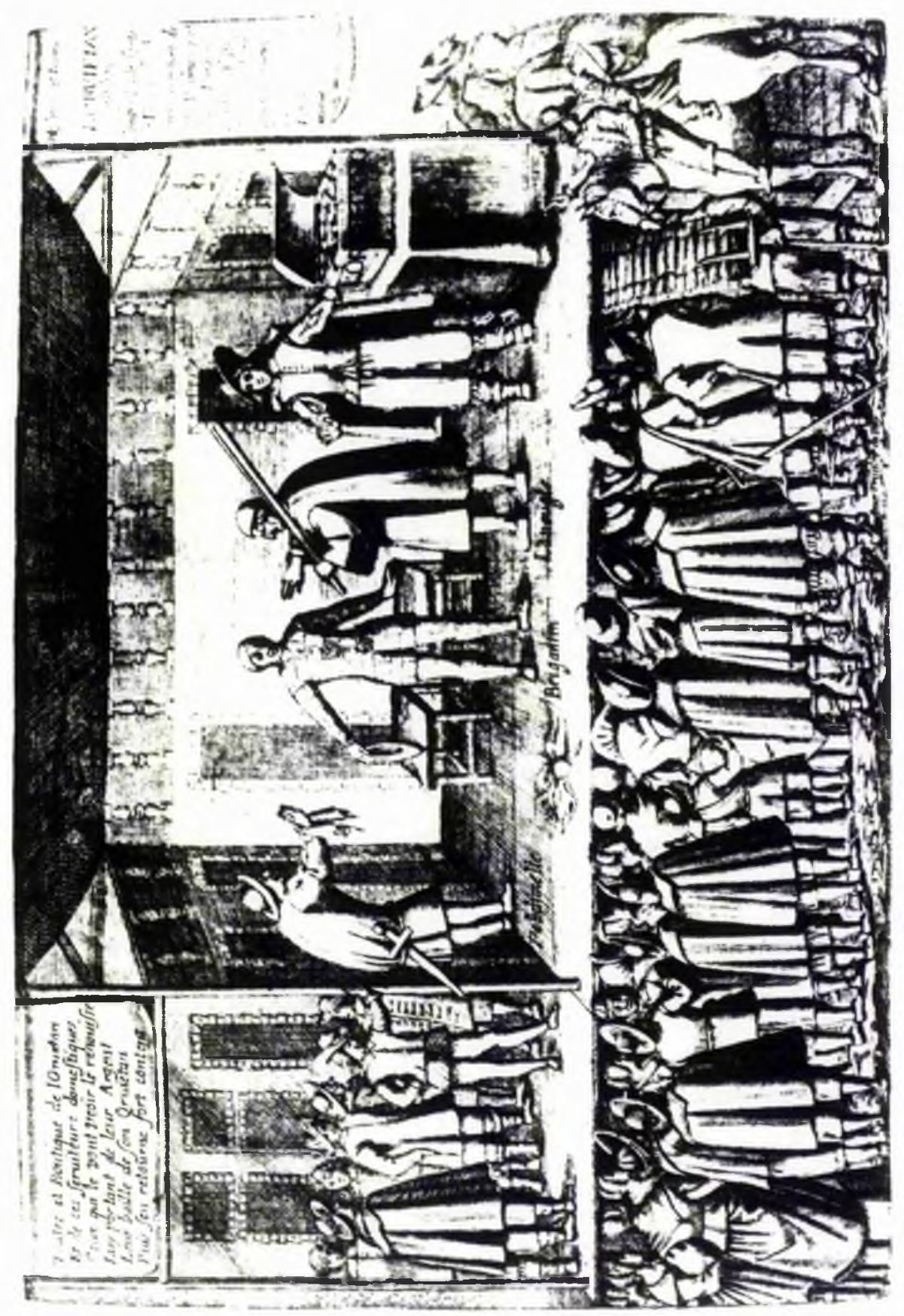


48 COMP. DERHETOR.

89

A Dies mon Koy, ES Reine, eo mes Amis

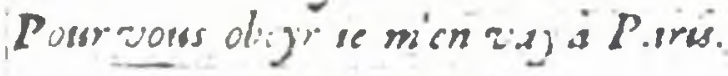

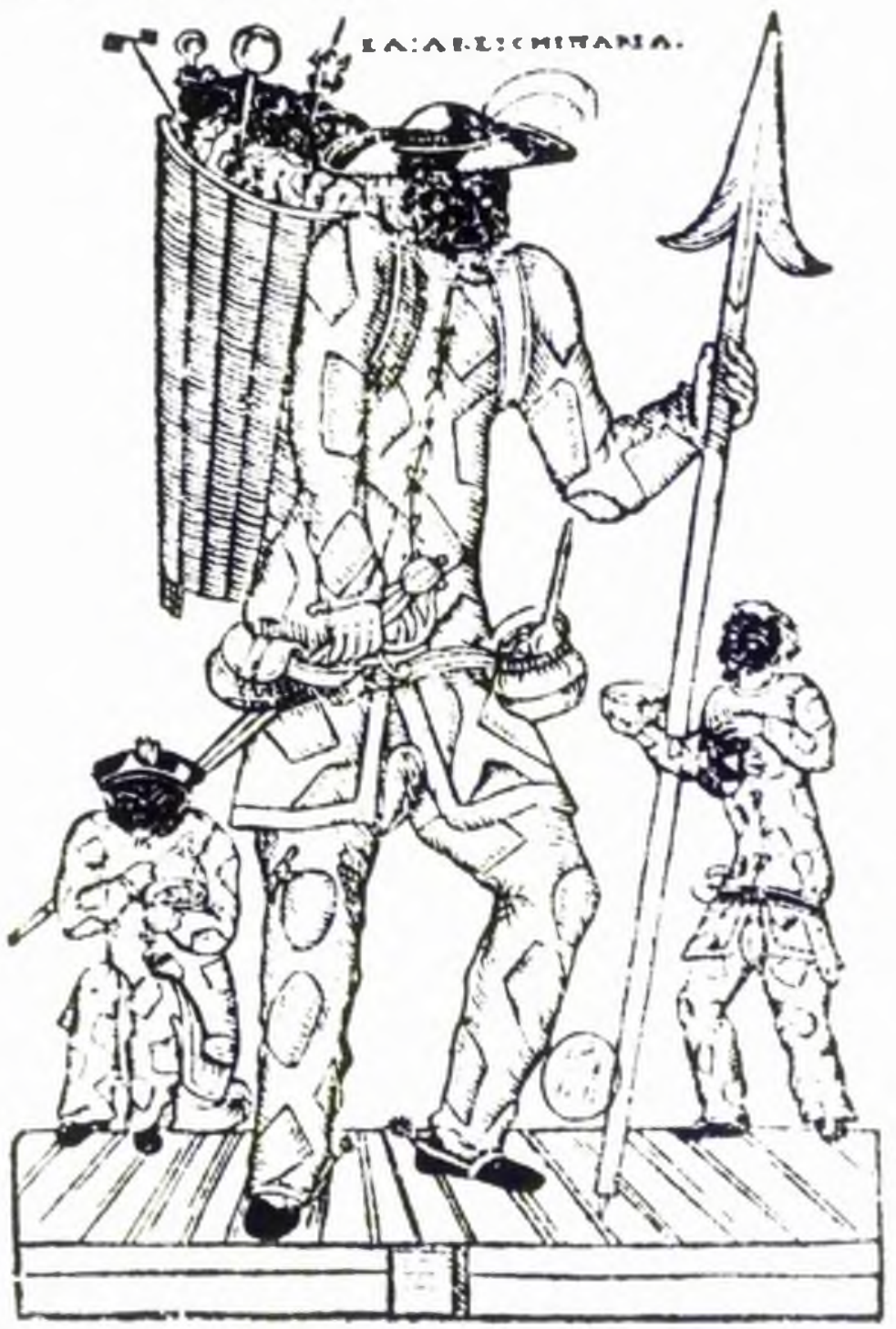




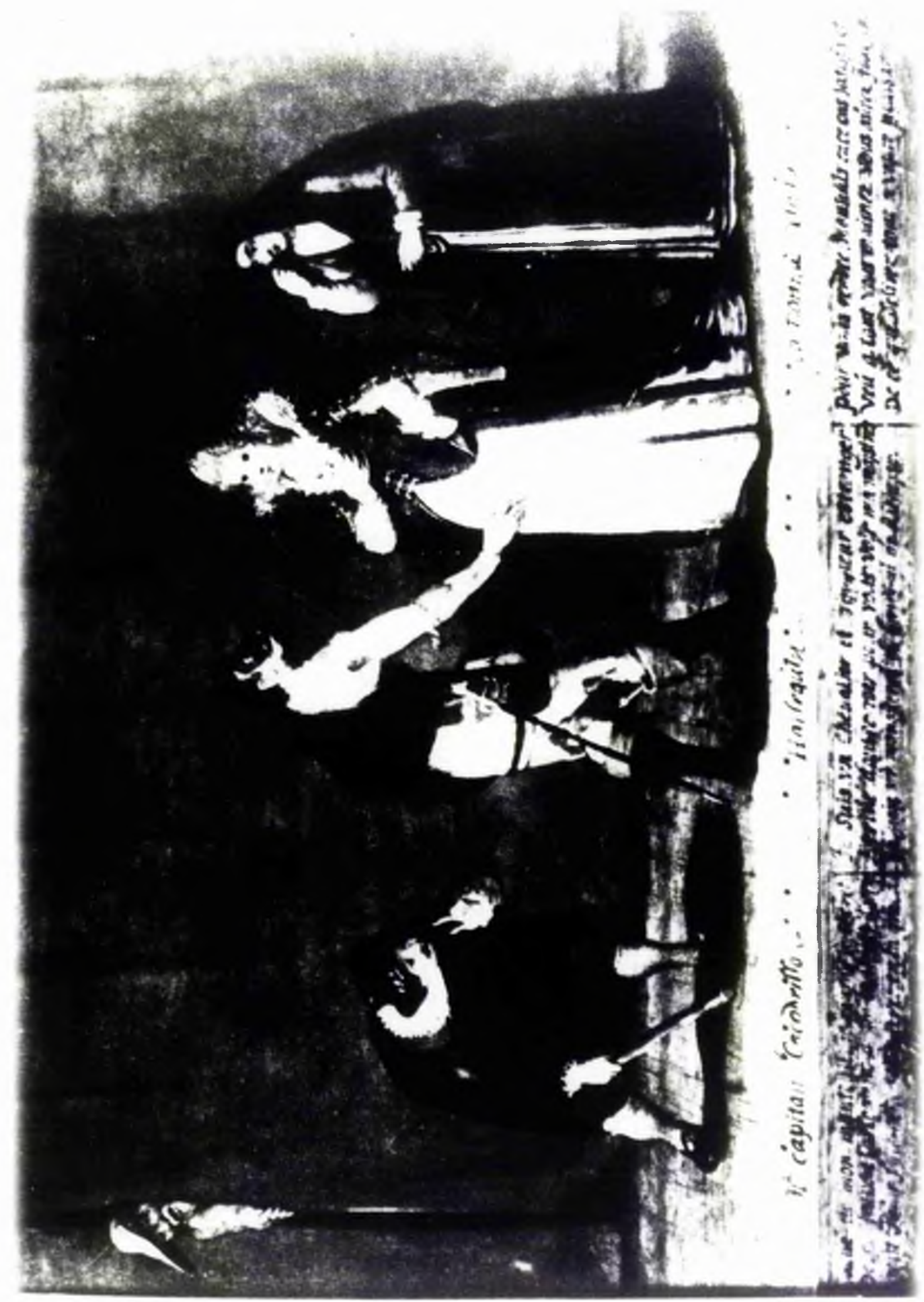




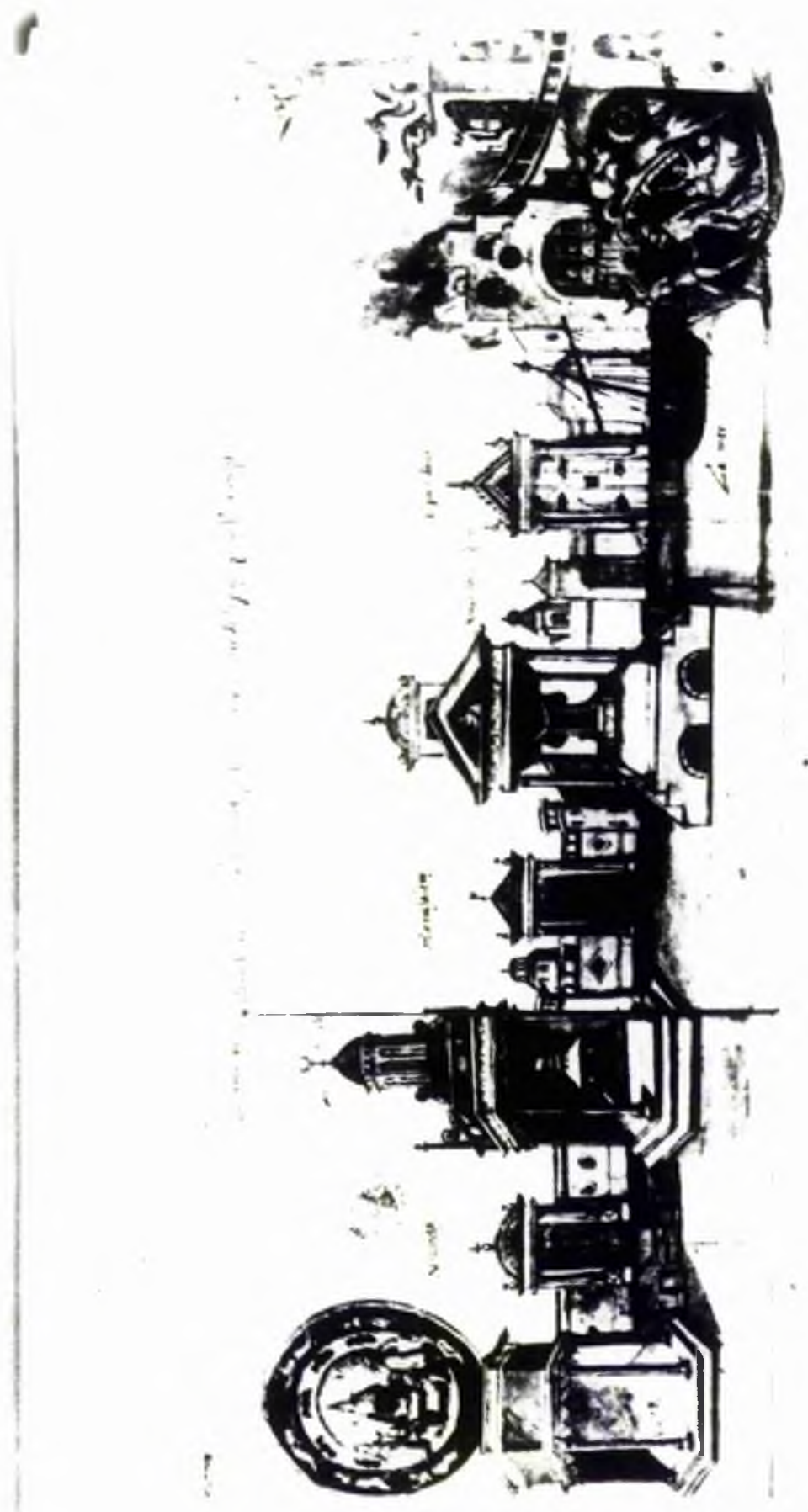




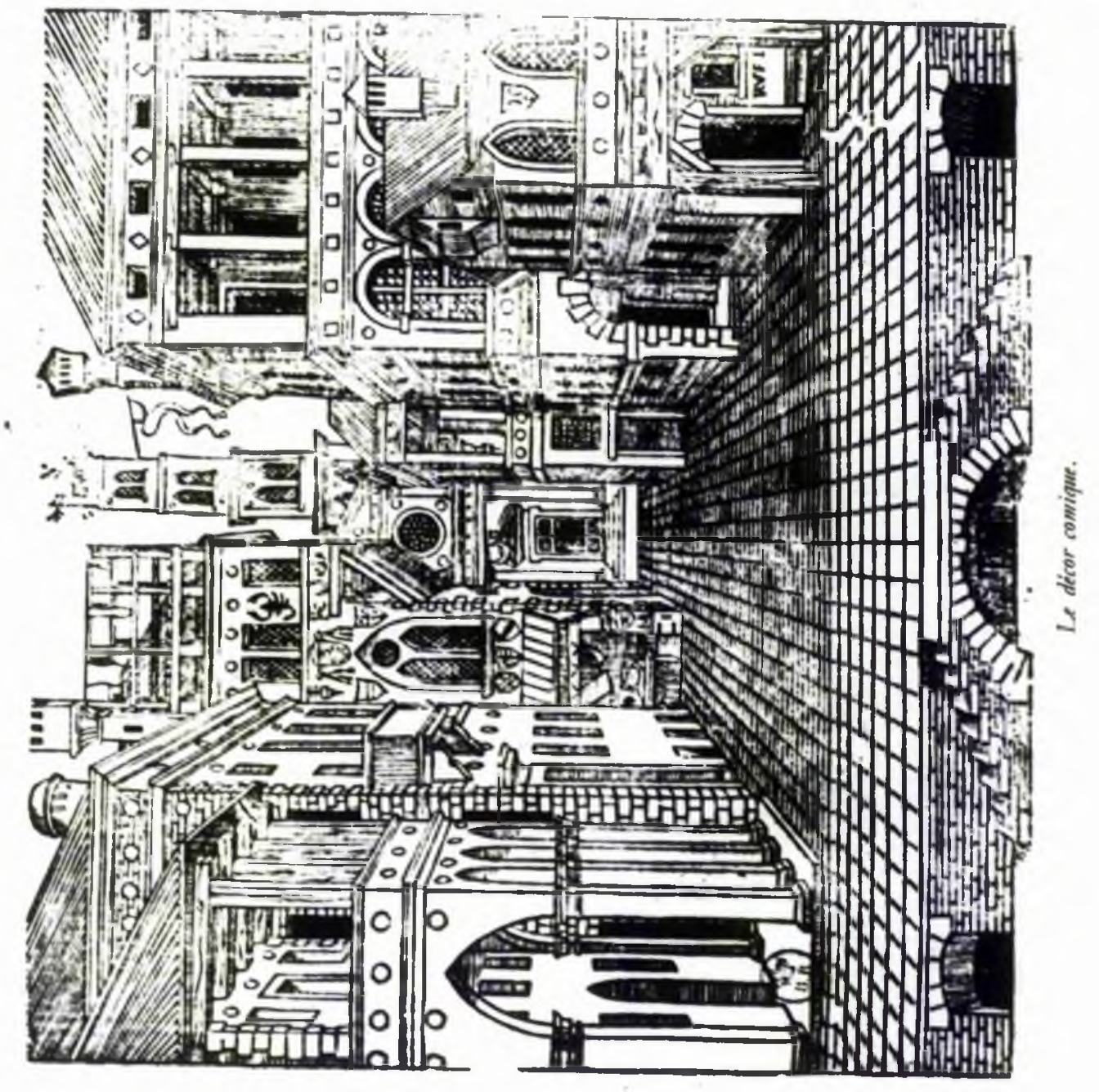




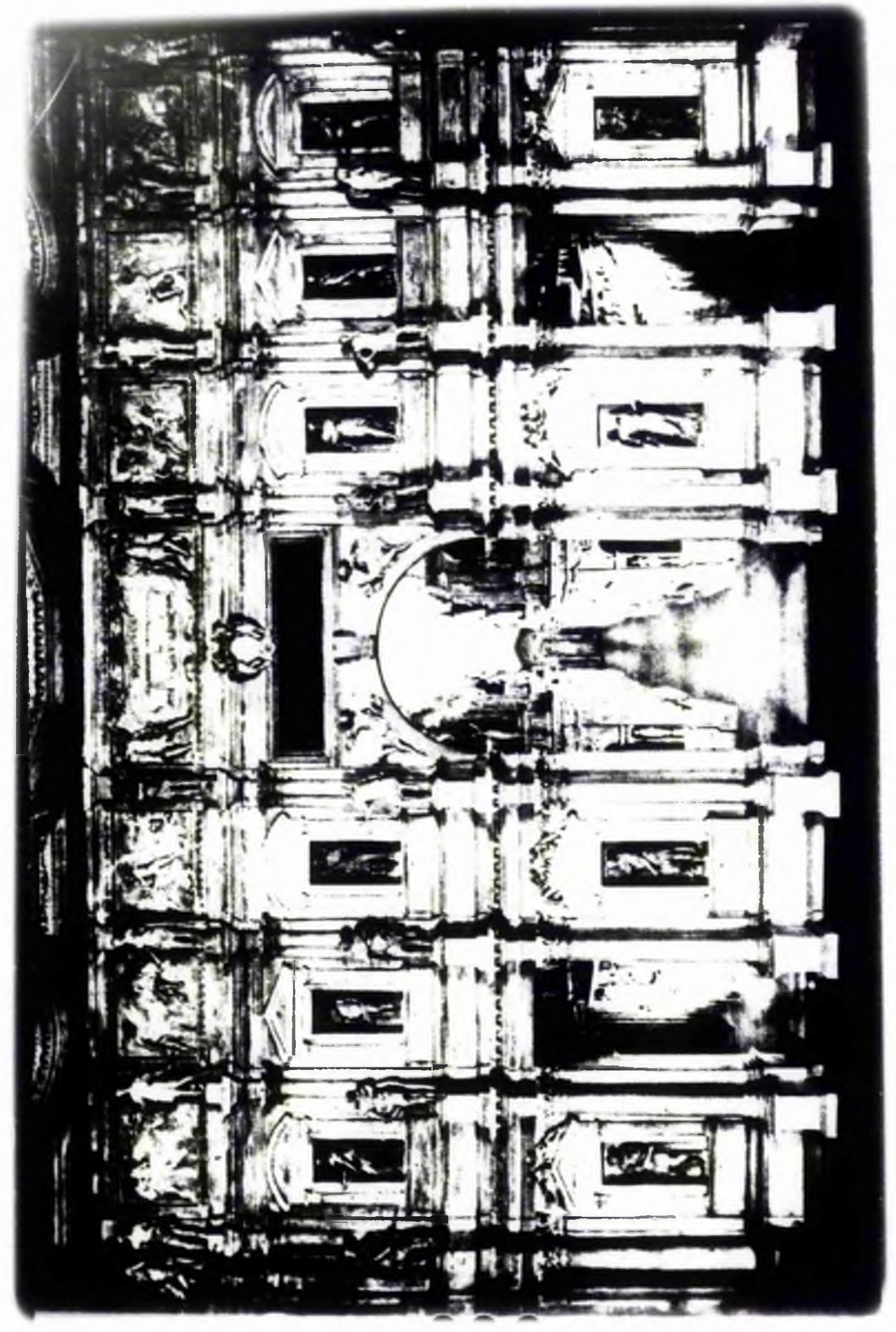




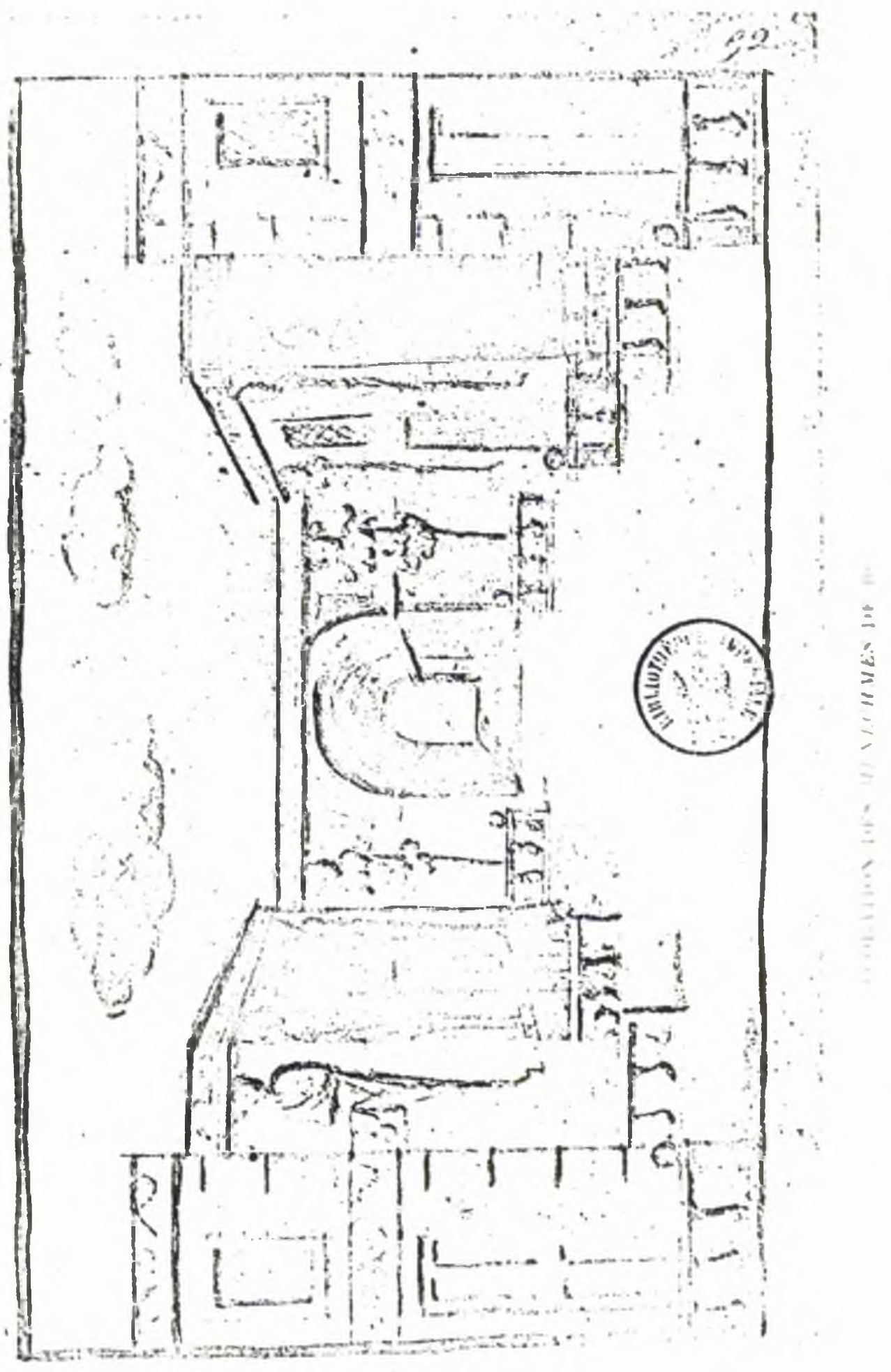




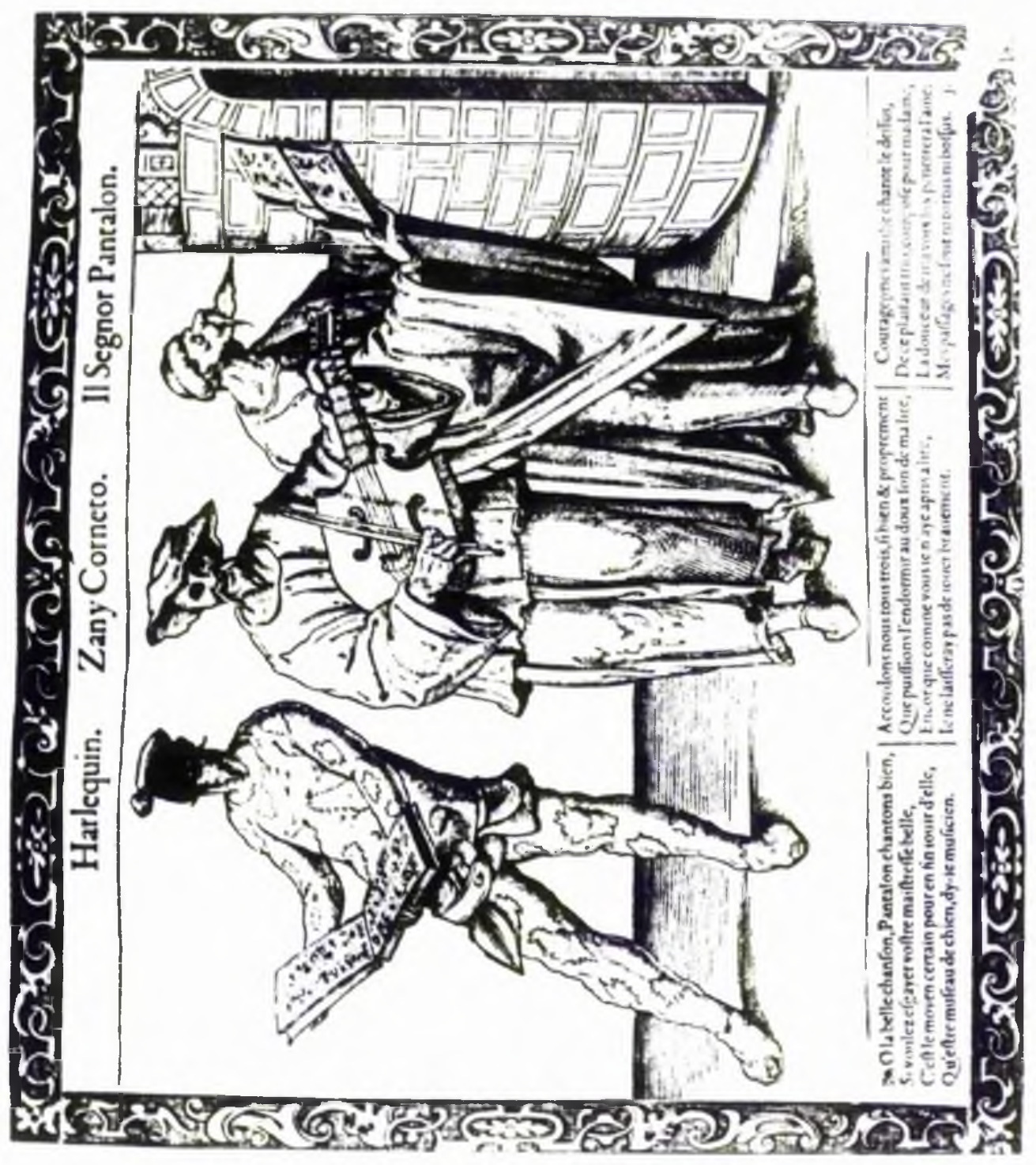




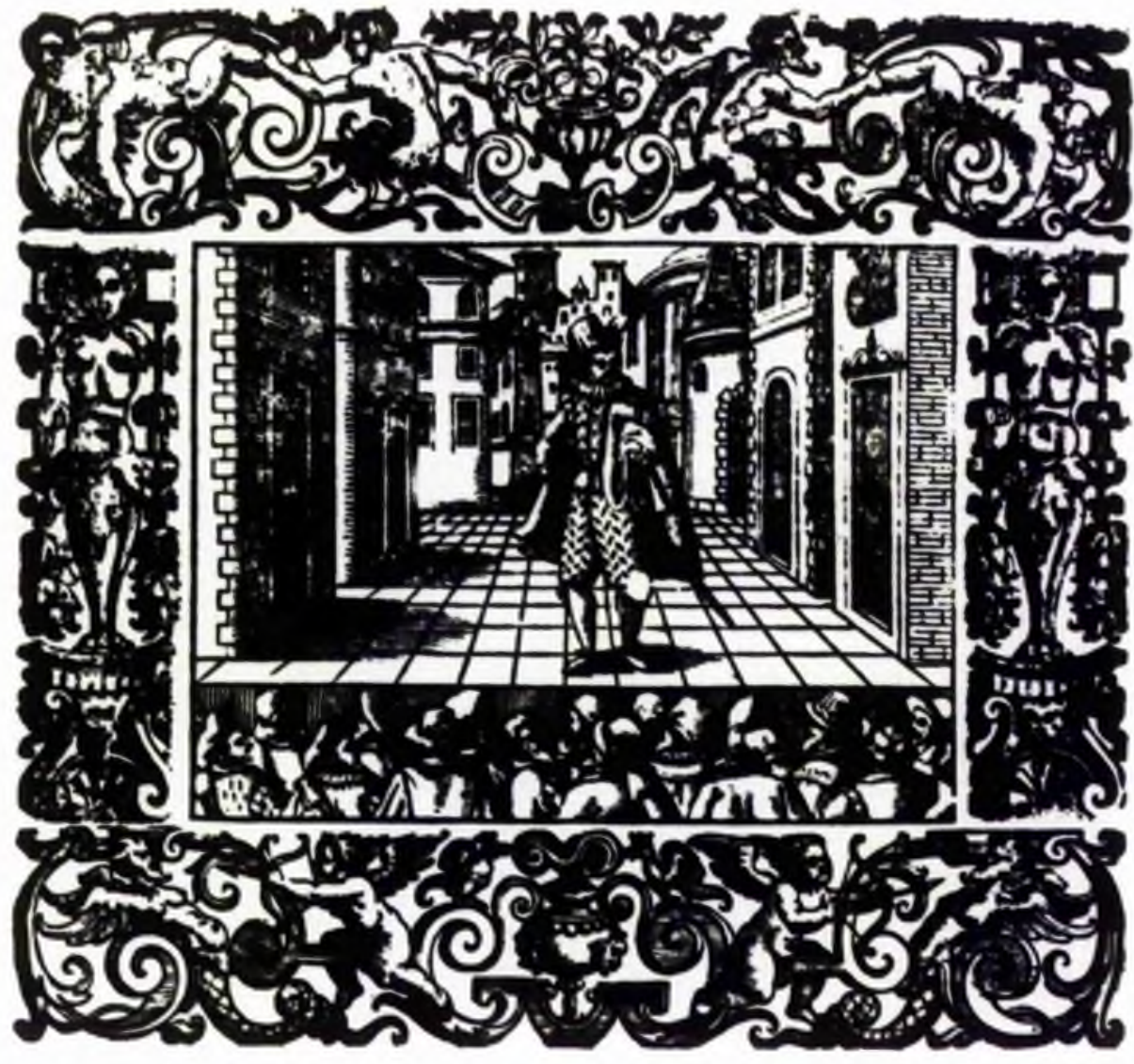

\section{PROLOGO, LELIO.}

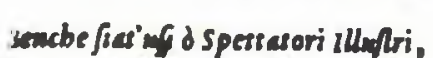
Solo di rimir ar Tragici aspetri, 0 iomici.pparati In rarie givfo ormati, roi peró monfdegmate Quifle Comedis noftra, Se mon di ricca, e vaga Scema adorne, Almen ci dopia moniti compole E la custid dowe fo rapprefoure
Quctopra, ilgran Theatro

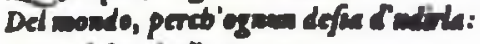
Ma voi fappiat'in cents, Che quefto di ari parto Spettacelo, fi wir a cen h mendr, Dovienate per lorecchie , e now par gleach Peto fllemiof face

L'is vere di vedere hwa afollede. 


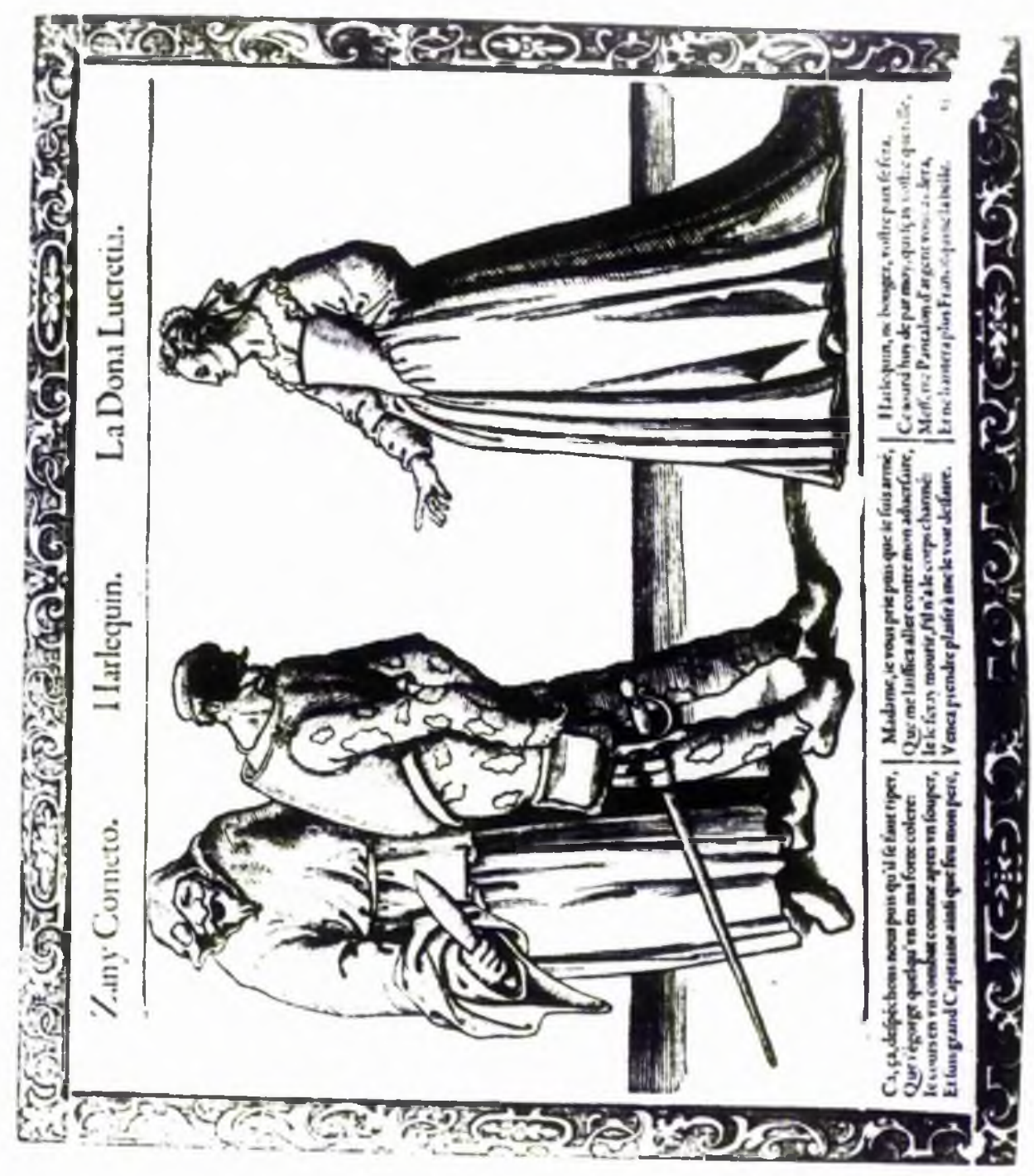

